\title{
SALSA Y DÉCADA DE LOS OCHENTA. APROPIACIÓN, SUBJETIVIDAD E IDENTIDAD EN LOS PARTICIPANTES DE LA ESCENA SALSERA DE BOGOTÁ.
}

\author{
Presentada por Bibiana Delgado Ordóñez \\ para optar al grado de \\ Doctora por la Universidad de Valladolid
}

Dirigida por:

Enrique Cámara de Landa

Rubén López-Cano 
Con respeto y admiración, a mi madre Aura Marina 


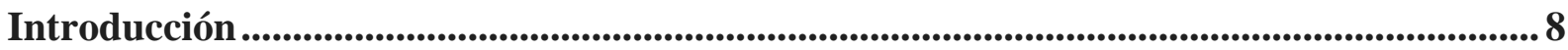

Capítulo I. Experiencia Estética en las Músicas Populares Urbanas ................................. 19

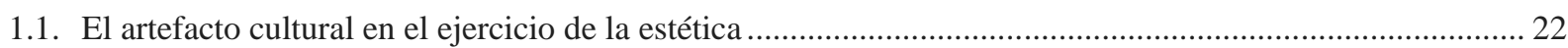

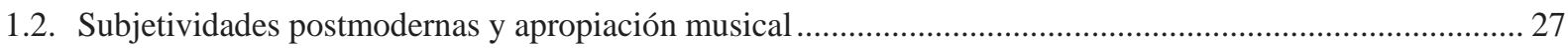

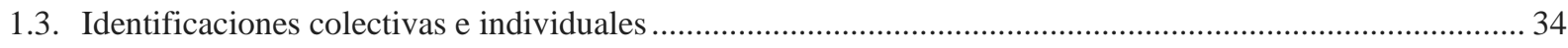

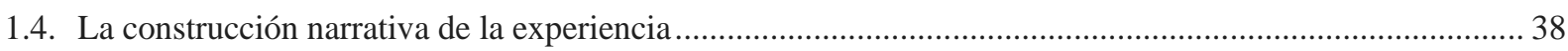

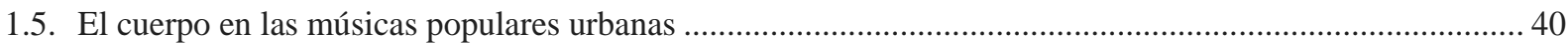

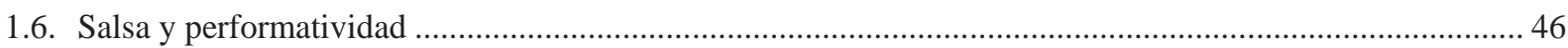

Capítulo II. Apropiación de la Salsa en Colombia ................................................................. 51

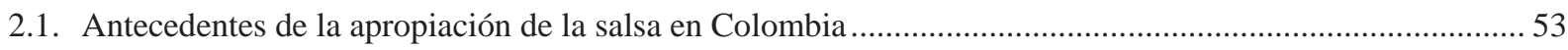

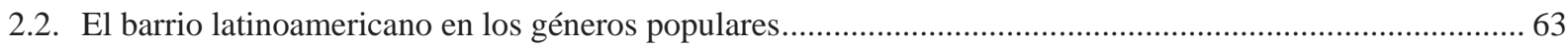

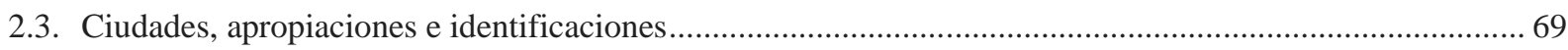

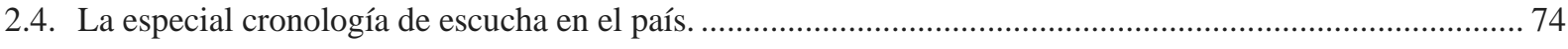

2.5. El imperante sentido de la vieja guardia en Bogotá. Programadores y Coleccionistas .............................. 80

Capítulo III. Salsa y Mundos de Sentido ............................................................................. 103

3.1. Música caribeña, tropical y salsa: la realización de la felicidad....................................................... 104

3.2. Rumba y libertad en la escena salsera bogotana ....................................................................... 109

3.3. Universos sonoros en la intimidad de la escucha ....................................................................... 120

3.4. La «melodía», interpelación inexorable en el escucha viejaguardero .................................................... 132

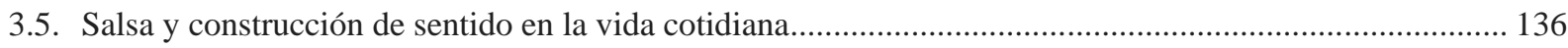

3.6. Desplazamiento de la música en la re-creación y reproducción de la salsa ......................................... 146

Capítulo IV. Subjetividad y performatividad del «yo»: Quién se es en la escucha de

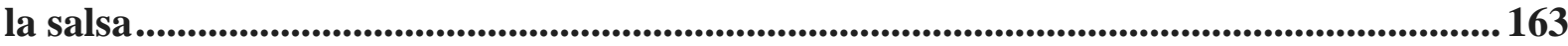

4.1. Vocalidad: identificación y representación .................................................................................... 165

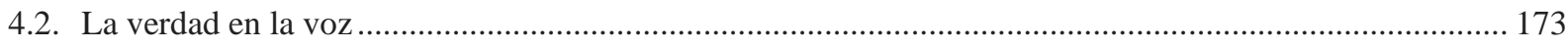

4.3. Intérprete y figura: la apropiación de las historias de vida............................................................ 181 
4.4. Subjetividad y lírica del lenguaje callejero

4.5. Personajes del barrio y representación. La decepción de Sofía....

4.6. Bogotá, caos y sentido: agencia de la salsa en una política del cuerpo...

Conclusiones.

Circuito Salsero en Bogotá

Discografía tratada en la investigación. 


\section{TABLA DE FIGURAS}

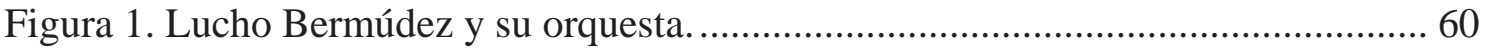

Figura 2. Carlos Vives y Egidio Cuadrado.......................................................................... 63

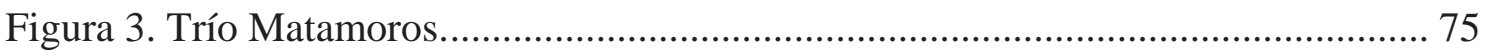

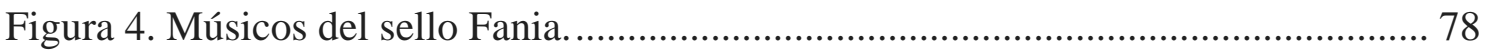

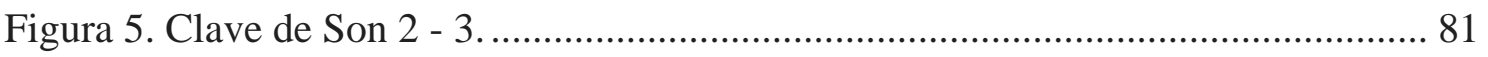

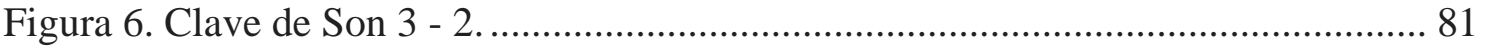

Figura 7. Score del tema «Aguanile» - Introducción. Fragmento.................................. 82

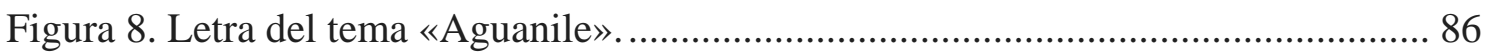

Figura 9. Score del tema «Tú me vuelves loco» - Introducción. Fragmento. ................. 88

Figura 10. Letra del tema «Tú me vuelves loco». ........................................................ 90

Figura 11. Ismael Carreño. Café Bohemia 1996. ......................................................... 94

Figura 12. Jenny Pérez y Hernando Gómez. .............................................................. 96

Figura 13. Discos de la colección de Francisco Cantor................................................. 101

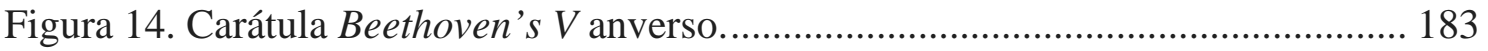

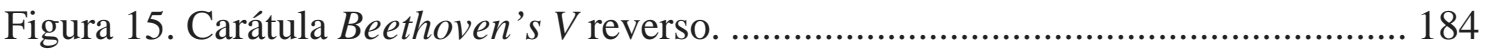

Figura 16 Triste y vacía. Introducción. Trombón......................................................... 208 


\section{AGRADECIMIENTOS}

Esta tesis fue posible gracias a la colaboración de los doctores Enrique Cámara de Landa y Rubén López-Cano, cuya participación a lo largo del proceso fue definitiva para llevarla a feliz término. Además de su disposición, motivación y dedicación, marcaron una ruta de múltiples aprendizajes que han hecho de mí un mejor ser humano y una mejor profesional.

Cuando volví a Colombia para realizar el trabajo de campo, fueron muy significativas las conversaciones del grupo de estudio encabezado por los doctores Carolina Santamaría-Delgado y Óscar Hernández Salgar. Las conversaciones en el grupo alimentaron mi curiosidad por el estudio de las músicas populares en el país y además recibí valiosos y oportunos comentarios para el desarrollo de mi trabajo.

Por su parte los miembros del Grupo de Investigación Interdisciplinar en Arte y Educación, Mónica Briceño Robles, Abelardo Jaimes Carvajal y Luz Dalila Rivas Caicedo, grupo al cual pertenezco, han sido siempre de gran apoyo y estímulo para mí en lo personal y para continuar con esta ardua tarea.

Me es imprescindible manifestar un profundo reconocimiento a todas las personas, hombres y mujeres, rumberos, oyentes, comerciantes, coleccionistas, programadores y expertos, que me ofrecieron los testimonios sobre su experiencia con la salsa. A través de sus reflexiones, memorias y experiencias, me permitieron adentrarme en sus vidas y observar de qué forma han construido mundos de sentido a través de la música.

Expreso una especial gratitud a los expertos que compartieron con amplitud y generosidad su tiempo y conocimiento para con este proyecto. Aunque no los mencione a todos, saben que les adeudo a todos y a cada uno un capital de saber que ha sido vital para esta tesis: Claudia Forero, Ismael Carreño, Enrique Sánchez, Wilson Córdoba, Francisco Cantor, José Arteaga, Enrique Romero (Q.E.P.D), Gustavo Adolfo Parra, José Luis Pascumal, Carolina Santamaría-Delgado, Natalia Castellanos y Luz Dalila Rivas Caicedo. 
Para finalizar, debo mencionar a los seres queridos que han estado presentes en todo este recorrido, cuya paciencia, cuidados, dedicación y larga espera han sido definitivos para emprender y culminar esta tesis: mi madre, Aura Marina Ordóñez en Pasto, Colombia, y mi gran amigo Gerardo Benavides Martínez en Barcelona, España. De igual manera, a los que ya no me acompañan en este camino pero cuyas instrucciones, amor y ejemplo fueron el simiente para forjar mi profesión: Mi padre Bernardo Delgado de Guzmán, mi tía Esperanza Delgado de Guzmán y mi maestro y amigo José Guerrero Mora. 


\section{INTRODUCCIÓN}

A finales de la década de 1970 estalló en el cuadrante latino de Nueva York, El Barrio, el boom de la salsa, cuya raíz en el son cubano se explica en las migraciones latinoamericanas hacia Estados Unidos desde los años veinte. Reflejos de este boom permearon el ambiente musical colombiano a través de la radio y del tránsito discográfico, que encontraba en las costas Pacífica y Caribe colombianas un aliado estratégico por su geo-localización y por la apertura de su gente a la recepción de las músicas caribeñas. La salsa evidencia una conexión de elementos musicales al igual que de ciertas maneras de ser y de sentir que se vehiculan en el circuito de territorios caribeños; por lo cual la consigna de James Clifford, «la conexión intercultural es y ha sido, durante mucho tiempo, la norma» $(1997,5),{ }^{1}$ se aplica directamente al fenómeno salsero en Colombia. Los habitantes de las zonas costeras encontraron en la salsa otra realización inmediata de la emocionalidad, la socialización y la corporeidad que poco a poco hallaron, también, las ciudades del interior; bastante diferentes a las del Caribe en cuanto al clima, el entorno, el carácter de sus habitantes y la constitución de las ciudades, entre otras características contrastantes. En este proceso de apropiación cultural es importante observar el origen y, a la vez, el sentido urbano de la salsa en Nueva York, ya que la expresión salsera condensa la vivencia cotidiana de las personas en la desordenada y compleja metrópoli de finales de siglo, de mayor resonancia con Bogotá, lejos del paisaje natural y la calidez de la vida tropical.

La salsa se arraigó en la capital colombiana a finales de los años setenta impactando, sobre todo, en públicos juveniles que han seguido cultivando su escucha aún a día de hoy. Instalada en la cotidianidad de los salseros, contribuyó -y contribuye- a generar diversos significados en sus vidas. El oyente bogotano ha establecido múltiples vínculos con la salsa, que van desde el desfogue corporal en la escena ${ }^{2}$ rumbera hasta la

\footnotetext{
1 «Intercultural connection is, and has long been, the norm».

${ }^{2}$ La definición de «escena musical» que aporta Will Straw sirve a este análisis, en cuanto noción contrapuesta a «comunidad musical». Según Straw una comunidad está conformada por una población relativamente estable cuya implicación con la música está arraigada en un patrimonio histórico geográficamente localizado. «Una escena musical, por el contrario, es aquel espacio cultural en el que coexisten una serie de prácticas musicales que interactúan entre sí dentro de una variedad de procesos de diferenciación y según trayectorias de intercambio muy diversas» (1991, 373). La salsa es una apropiación cultural y, por otra parte, la escena salsera bogotana evidencia una gran variedad de prácticas; lo que deja muy clara la participación de públicos sumamente heterogéneos. Además, conforme se ha desarrollado en Bogotá, en un comienzo y en el periodo del boom salsero, fue extensible a las calles de la ciudad y a lugares de interacción social como la casa de familia, o plazas y parques donde se celebraban festividades locales. Es decir, la escena no se limitó a las discotecas o a los conciertos públicos.
} 
construcción de lugares de intimidad, donde la música ayuda a demarcar territorios personales y privados. Pero valga hacer la siguiente precisión: esta investigación se centra en personas concretas de la escena bailable de la salsa durante la década de los ochenta y en las formas en las que han ido construyendo significado, apropiación y subjetividad con la salsa a lo largo de su vida; incluso posteriormente a ese periodo. En ese orden de ideas, cabe anotar que este sector de personas, participaron en la escena pública de la salsa en Bogotá durante aquel tiempo pero el presente estudio no se limita a entender sus procesos en ese periodo. Los sujetos colaboradores de este trabajo accedieron a la salsa a través de estas oportunidades que les daba el entorno salsero en la ciudad para buscar su sentido subjetivo en los años ochenta; mas no se pretende elaborar un cuadro del desarrollo del género musical en la Bogotá de aquel entonces, sino de cómo ha sido todo este tiempo para algunos de los personajes que participaron en esa escena.

Ahora, debido a que la mayor parte de la escucha se realiza a través de registros grabados, discos de vinilo y discos compactos, se generan otros hábitos en la cotidianidad. En la intimidad de la escucha privada el oyente percibe con mayor atención las voces de sus intérpretes y las letras de las canciones; afina su oído musical y reconoce el rol de los instrumentos en el conjunto; incluso, al autor de la ejecución si es un melómano muy competente. Señala, entonces, las descargas de piano o percusión que más le impresionan y tiene a la mano los discos con las trompetas o trombones que más lo conmueven. De acuerdo con la inquietud que lo perturbe, elige el tema más apropiado para potenciarla o, al contrario, el que sirva de conjuro. Tales ejercicios alimentan la performance y promueven diversas identificaciones con el género musical.

Así, es necesario comprender qué sucede en la experiencia estética de la salsa, puesto que ella orienta la realización de múltiples, íntegros y complejos mundos de sentido en cada oyente. Razón por la cual es indispensable definir las formas en que la experiencia estética de la salsa es artífice de los significados que las personas elaboran para constituir las relaciones consigo mismas en la búsqueda de dotar de identidad un «yo» inevitablemente móvil; luego, para proveer y significar los roles que las personas desempeñan en el juego o movimiento de posiciones sociales y, por último, para armar los escenarios en que han de librar su batallas por el sentido; es decir, por la construcción de su verdad o de su realidad. 
Si nos remitimos al sujeto oyente, al sujeto receptor, cuya finalidad con la música no es ser un experto en las disciplinas musicales, sino hacer uso de ella en la formación de subjetividades, la autorregulación emocional o la elaboración de la sociabilidad y a la vez hacer usos colectivos que reditúen en significados históricos y socioculturales, ha de considerarse que bajo el precepto experiencial la corporeidad juega un papel sustantivo en la vivencia musical. Este tipo de sujeto receptor, individual o colectivo, tiene su contacto primario con la música en la percepción y la emoción, y a partir de este proceso se determina vitalmente también su corporeidad. De aquí, además, hay que anotar que su interacción con la música sea en principio previa a las operaciones lingüísticas o esté desarticulada de ellas, y que por lo tanto su significación no esté elaborada en términos de lo lingüístico.

En lo que atañe a la precariedad de manifestaciones orales que describan la experiencia o los significados, puede radicar la falta de discursos al respecto. Quizás ello suponga parte de la escasa producción teórica sobre las funciones de las músicas urbanas en el país, aunque claramente intervengan factores de distinta índole. No se puede negar que, no solo en Colombia, el estudio de la experiencia estética y de la significación de las músicas populares sea incipiente y apenas esté considerándose en la Academia. Más todavía, lo son los estudios sobre la recepción musical en los públicos. Hay un campo que se está consolidando y sea ésta la oportunidad de enriquecerlo, al problematizar dichos aspectos y plantear explicaciones concretas que nacen de la experiencia misma de los escuchas de la salsa.

A instancias de esta problemática surgen las siguientes preguntas:

- ¿Qué significados de valor social se producen en la apropiación de la salsa viejaguardera ${ }^{3}$ en Bogotá?

- ¿ ¿De qué forma la experiencia estética en la salsa agencia mundos de sentido en sus oyentes?

\footnotetext{
${ }^{3}$ En Colombia la salsa viejaguardera es la que produjo y distribuyó, mayoritariamente, el sello neoyorquino Fania y que fue fenómeno cultural y comercial en el país hacia finales de los setenta y a lo largo de la década del ochenta. Abarca también toda la música antecesora de la salsa que tiene sus raíces en el son y otros aires cubanos, portorriqueños y caribeños en general. No contempla los desarrollos o subgéneros nacidos a mediados de los ochenta y que han provocado un boom en los noventa o recientemente. También se utiliza el apelativo viejaguardero para identificar al tipo de melómano que escucha o colecciona esta clase de salsa. La definición se irá complementando a lo largo de la introducción y los primeros capítulos.
} 
- ¿¿Mediante qué procesos se acciona la producción de subjetividad y, por lo tanto, la performatividad del yo en la escucha de la salsa?

Estos grandes cuestionamientos encierran otros subsidiarios que fueron abonando importancia a lo largo de la investigación. Entre ellos: ¿Cómo se establece una nueva taberna $^{4}$ que cambia las formas de vivencia social de la salsa en Bogotá?, ¿De qué manera la performatividad en el sonido salsero articula identificaciones o identidades?, ¿Cuál es el papel del cuerpo salsero en la producción de significados?, ¿De qué forma la salsa contribuye al establecimiento de un territorio personal?, ¿Cómo se construye en la salsa un yo deseado que el oyente puede incorporar a través de la operatoria performativa?, ¿En qué medida el «otro» representado en la salsa asiste la elaboración de un nuevo yo? Evidentemente, estas preguntas se desprenden de la experiencia musical y se ha tratado de responderlas a partir de la misma experiencia. Mas surge aquí un traspié considerable en el intento de verbalizar la vivencia y de producir discursos a partir de una información empírica: la precariedad de un argot disciplinar en el campo musicológico que permita definiciones con términos unificados y estables sin la indefinida recurrencia a la metáfora. A lo que podrían surgir cantidad de interrogantes. Agrego: ¿Es posible que el trabajo etnográfico consolide un vocabulario de acuerdo a las nuevas necesidades terminológicas en la investigación musical? $\mathrm{O}$ ¿Es posible que los vocablos que se han ido acuñando en el uso cotidiano de los oyentes sean asumidos por las disciplinas académicas y consigan el estatus requerido para usarse en la descripción investigativa?

Bajo los anteriores interrogantes se pretende argumentar a favor de las siguientes hipótesis. Las interacciones sociales generadas en la escucha de la salsa en Bogotá, ayudan a consolidar bases de conocimiento en torno a la salsa, la música cubana, caribeña e, incluso, de otras latitudes, en diferentes grados de profundidad y erudición, aportando significados que dan paso a un sujeto capaz de visibilizarse y posicionarse en la escala social del medio salsero bogotano.

La salsa agencia mundos de sentido en tanto la experiencia estética posibilita la generación de múltiples realidades. La sonoridad de la salsa instaura escenarios de

\footnotetext{
${ }^{4}$ Hay varias clases de lugares donde se puede escuchar y bailar salsa. La «taberna» es un sitio para bailar pero, ante todo, para escuchar salsa y charlar. No tenían las dimensiones de una discoteca, que podía albergar más gente y grandes pistas de baile. Actualmente, sitios de este estilo casi no se ven, pues fueron más usuales a finales de los años setenta y en los años ochenta del siglo pasado.
} 
felicidad, libertad y bienestar que son una parte significativa de la vida de sus melómanos. Esta realización es inherente a la experiencia del cuerpo ante el sonido y se encuentra articulada con las condiciones de sus oyentes en términos del contexto de la escucha, las asociaciones con el pasado, las capacidades performativas del oyente y la elaboración narrativa de la experiencia. En la vida de estos oyentes no sería posible agenciar determinadas realidades -mundos de sentido- sin la intervención de la salsa.

La performatividad del «yo» está sujeta a las interpelaciones que produce la salsa en cada melómano. Detrás de las interpelaciones naturales que producen el ritmo frenético o el acento cadencioso de la salsa o las músicas caribeñas, son inevitables las relacionadas con la vocalidad y las historias de los intérpretes, las líricas callejeras y el entramado músico-instrumental que los salseros denominan «melodía». En cuanto un sujeto es interpelado por estos elementos consigue incorporar o volverse aquel «otro» deseado, imaginado o extraño que forma parte del proceso de un «yo en construcción», evidenciando la identidad personal como un asunto de proceso y de experiencia.

Los objetivos de esta tesis son:

- Establecer los significados de valor social que se producen en los melómanos bogotanos con la apropiación de la salsa viejaguardera.

- Precisar los procesos mediante los cuales la salsa edificó, y edifica en la actualidad, mundos de sentido en sus oyentes, eje transversal de toda la tesis.

- Determinar las formas en que la salsa se integra a la subjetividad de sus melómanos y posibilita la performatividad del «yo» en términos de lo que las personas desean ser o encarnar.

En los antecedentes para la presente investigación se pudo detectar que la literatura sobre la salsa en Colombia, escrita o registrada en medios audiovisuales, es escasa, y normalmente se limita a constituir fuente primaria para la investigación. Por lo general, se encuentra un panorama descriptivo de la música que llegó a Colombia, sus intérpretes y algunas vivencias regionales de la misma, a veces, con muy buen detalle. Sin embargo, en su mayor parte, dicha bibliografía no se adentra en un análisis reflexivo e interpretativo de las relaciones que se constituyen en la compleja estructura que se teje entre la escucha, la subjetividad, la experiencia estética y la identidad cuando un 
artefacto cultural es apropiado; y en este caso, con la intensidad con la que ocurrió en los públicos salseros del país. En la presente tesis se apuesta por una interpretación de los fenómenos de significado inmersos en esas relaciones y que aún no se han tratado a profundidad. Además, se enfatiza en el sujeto oyente, el sujeto de la recepción, del cual escasamente se ha hablado en la literatura narrativa de la salsa en Colombia y en algunas, aunque juiciosas, tesis post-graduales. Por consiguiente, se hace un aporte teórico que rinde cuentas sobre el papel del género musical en la agencia del sujeto en lo individual y lo colectivo, inmerso en el contexto sociocultural colombiano. De esta forma, se contribuye a la vez a subsanar el vacío teórico que existe en el país sobre esta materia.

Las metodologías empleadas en la investigación fueron las siguientes:

- Entrevistas en profundidad: se realizaron 25 entrevistas en profundidad a distintos tipos de melómano: el rumbero corriente, el melómano que disfruta de la salsa también en casa, o solo en casa, el programador o Dj, el coleccionista y el experto. Hubo cuatro casos de músicos y un bailarín, ${ }^{5}$ profesionales, con la insistencia de que hablaran sobre su experiencia estética y los significados de la salsa en su vida, no acerca de sus desempeños artísticos. En las entrevistas salió a flote la historia musical del salsero y los usos y funciones que él ha ido dando a la música en su proceso de escucha.

- Conversaciones in situ y casuales: se registraron 33 conversaciones en algunos locales salseros y encuentros de audición colectiva en casas particulares o «escuchatas». Aquí se incluyen dos encuentros no programados que aportaron información sustancial al proceso.

- Análisis textual y musical: se analizaron textualmente las obras: «Aguanile», «Tú me vuelves loco», «Las tumbas», «El preso», «Pedro Navaja», «Juanito Alimaña» y «Triste y vacía». De las anteriores, se analizaron musicalmente «Aguanile» y «Tú me vuelves loco». Cada tema fue una alusión reiterada de mis fuentes. A la vez se hace un acercamiento a la vocalidad e historia de sus intérpretes, con lo cual se identifican las interpelaciones más recurrentes o más particulares del género salsero. No obstante, corresponde hacer una aclaración

\footnotetext{
${ }^{5}$ Mis colaboradores aluden al término «bailarín» para referirse a quien baila profesionalmente, es decir, quien ha tenido una formación o preparación específica y labora en escenarios reconocidos de la actividad. La voz «bailador» es para el fiestero o rumbero común que goza naturalmente de esta actividad.
} 
sustancial con respecto a lo que en esta tesis se llamará género musical, ${ }^{6}$ y es que la salsa está constituida por varios géneros y subgéneros musicales y diferentes estilos; en este sentido, la presente investigación focalizó en la corriente de la vieja guardia. Ésta la conforma la producción musical salsera originada en Nueva York y divulgada, mayoritariamente, a través del sello musical Fania. A la vez, esta corriente abarca los géneros cubanos, portorriqueños y caribeños en general, que han dado fundamento a la salsa neoyorquina. ¿Por qué esta corriente? Porque fue la que llegó a Colombia a finales de los setenta y en la plenitud de los ochenta. Fue la que vivió la juventud de aquel momento y continúa vigente hasta ahora en el ámbito viejaguardero bogotano, pese a que ya no resuene en los medios. Así que los melómanos salseros que conformaron las fuentes de esta tesis rondan, en la actualidad, entre los 40 y 60 años aproximadamente.

- Revisión bibliográfica: dada la transdisciplinariedad de la investigación se consultaron fuentes de carácter estrictamente musical -partituras, discos y libros de salsa-, otras de tipo iconográfico como carátulas de discos, fuentes sociológicas, antropológicas y otras provenientes de los Estudios Culturales.

- Marcos teóricos utilizados: para el análisis de la salsa en cuanto artefacto cultural, el pilar teórico fundamental es la estética pragmática abordada por John Dewey, que centra su atención en la experiencia y en la estética del receptor más que en la del productor. Con respecto a la identidad, los Estudios Culturales con Stuart Hall a la cabeza (1992a; 1996a), son precisos para explicar el fenómeno de la identidad y la identificación en la era del sujeto postmoderno. Por su parte, la performatividad musical, cuyo eje es el cuerpo, ha sido tratada dentro de las orientaciones de la semiótica performativa de Rubén López-Cano (2007a; 2007b; 2008; 2013b) y de la corporeidad en la experiencia musical de Ramón Pelinski (2005). En lo referido a las músicas populares urbanas, el trabajo de

\footnotetext{
${ }^{6}$ En las «Notas sobre el vocabulario» consignadas al final de esta introducción, expongo también que el uso del término «género» es bastante complejo en el caso de la salsa y pude decirse que es una discusión que todavía no se ha cerrado; tampoco tendrá lugar en este documento. Algunos estudiosos la asumen como tal y otros, no. Santamaría-Delgado comentaba que «Para muchos (sobre todo en la escuela norteamericana), el término salsa es un "término sombrilla" que engloba una cantidad de géneros musicales diferentes (guaracha, son, guajira, bomba, etc.), y cuyo sentido era, principalmente, servir como etiqueta de mercado: Todo lo que vendía la Fania, era salsa, independientemente de sus características musicales» (Santamaría-Delgado 2016, comunicación personal). Concepto que respaldan, además, algunas de mis fuentes y que se verá más adelante. En esta tesis se usa el término porque resulta muy práctico para tratar el conjunto de músicas que se adhieren a la voz «salsa», pero en ningún momento es una posición personal o académica que propenda por alguna de las vertientes de la discusión.
} 
Simon Frith (1996; [1987] 2008) y Richard Middleton (2006; 1990) aporta en la comprensión del significado que se construye en la música. En la misma línea Tia DeNora (2000) ofrece herramientas analíticas para entender la negociación de sentido que hacen las personas con los artefactos culturales. Finalmente, la construcción social del cuerpo y el cuerpo de poder que se performa en la salsa son abordados desde las teorías de Pierre Bourdieu (1979; 1986) y Michel Foucault (1979; 1982; 1988).

De esta forma, en el primer capítulo se establecen los conceptos teóricos requeridos para abordar la experiencia estética como proceso genuino de producción de subjetividades. Es imprescindible hacer un acercamiento a la evolución del concepto de estética bajo la visión kantiana sobre el arte a-funcional hasta la aplicación en la postmodernidad en las artes populares en las cuales la estética se erige por parámetros funcionales en el seno de la vida social, lo cual permite considerar la música popular como objeto-artefacto cultural. Para este cometido el concepto del arte como experiencia desarrollado por John Dewey ([1934] 2008) ofrece las herramientas indispensables para el abordaje de una estética pragmática; una estética que contempla a todas las personas como seres estéticos. Gracias al papel que juega la experiencia estética en la vida cotidiana se logra entender los mecanismos de configuración de subjetividades, ligados en este caso a las prácticas de escucha musical. En esta sección resulta, además, imprescindible la localización del fenómeno estudiado con relación a la postmodernidad y el lugar que la identidad y la identificación ocupan en esta era.

En el segundo capítulo se abordan los antecedentes que facilitaron el asentamiento y apropiación del género en Colombia. Se describen los intentos de constituir el proyecto musical nacionalista desde fines del siglo XIX hasta la primera mitad del XX, que se habían centrado en el bambuco andino. Pero el fracaso de dicha tentativa provocó un vuelco identitario que se dirigió a las festivas músicas tropicales de la costa Atlántica y al resto de músicas del eje Caribe. Otra parte de los antecedentes enfoca la constitución del barrio moderno que marca decisivamente su influencia en la sonoridad y textualidad de las músicas populares urbanas latinoamericanas. Este barrio admite una enorme similitud con el cuadrante latino de Nueva York; habitado por minorías migrantes, específicamente centro y suramericanas, que presentaban problemas de marginalidad, pobreza y descomposición social, pero desde el cual comenzó a emerger la salsa urbana en la década del sesenta. Luego se adentra en la apropiación del género en las ciudades 
del interior de Colombia, especialmente en Bogotá y, posteriormente, muestra la forma en que los melómanos incursionan en el conocimiento histórico de la expresión y ahondan en los ritmos cubanos y antillanos que la anteceden y la originan. La última parte del capítulo enfatiza en la predilección del salsero bogotano por la salsa de la vieja guardia. Sin el ánimo de generalizar tal tipo de preferencias dentro del género, se aproximan algunas razones por las cuales aquellos que disfrutaron el boom salsero de los ochenta exhiben cierto favoritismo hacia la salsa neoyorquina y sus antecedentes cubanos.

Después de observar los elementos primarios de identificación con el género, en el tercer capítulo se examinan los procesos en los cuales la experiencia estética y el significado social de la salsa agencian mundos de sentido en sus oyentes. En la primera parte del capítulo se trata la experiencia de los jóvenes en la rumba ${ }^{7}$ bogotana de la década de los ochenta; se ilustran los pormenores de la vivencia colectiva de la salsa y, por ende, las funciones sociales que cumplía y aún ostenta. Eran vitales la presencia del barrio y los lugares de disfrute de la salsa en la ciudad como generadores de nuevas estéticas, en tanto intervenían directa y profundamente las maneras en que se consumía y vivenciaba la música; maneras que en la actualidad, presentan singulares desarrollos. Uno de los aspectos más trascendentales fue la construcción categórica de la salsa como el género de la alegría; otro, la modelación de la libertad juvenil en los menesteres rumberos de los años ochenta que dotaron de sentido una vida urbana en Bogotá. La segunda parte del capítulo se dirige a la experiencia individual, la cual está mediada por las nuevas formas de escucha y las nuevas funciones que los melómanos le confieren a la salsa desde sus necesidades y anhelos particulares. Aquí la experiencia íntima y privada de la música adquiere un papel preponderante y definitivo en la vida cotidiana. Al final del capítulo se refieren las formas en que la música se ha integrado a la corporeidad de sus oyentes. Tal incorporación incide directamente en las maneras en que la música dota a los recuerdos de un tiempo en el cual transcurrir, colabora en la fijación de experiencias de vida, contribuye al ajuste de la experiencia narrada y revela el continuum mente-cuerpo; es decir, el indisociable vínculo entre el interior y el exterior de cada individuo.

\footnotetext{
${ }^{7}$ «Rumba» es el nombre que se le da en Colombia, además de otros países del Caribe, a las fiestas donde prima el baile de música salsa o tropical colombiana. La rumba se desarrolla convencionalmente en discotecas, bares o salsotecas y quienes la practican suelen denominarse rumberos.
} 
En el cuarto capítulo se observan los procesos mediante los cuales la música colabora en la producción de subjetividad de los oyentes; procesos que guardan una estrecha relación con las interpelaciones y articulaciones más recurrentes en los melómanos salseros. A través de ellos se tiene en cuenta un «yo performativo» que modula su identidad mediante mecanismos de identificación y representación, para lo cual se estudian algunos elementos constitutivos de la salsa. Así, en concordancia con la vocalidad de los cantantes se revisan las características que vuelven peculiares algunas voces; entre ellas, las de La Lupe y Héctor Lavoe, y se determinan los elementos que causan la conexión con el oyente. A través del estudio de la música y la imagen de Frankie Dante, se establece la representación por antonomasia de la resistencia y la protesta del inmigrante latinoamericano que busca reivindicación social en Nueva York. Las líricas de las canciones reflejan el complejo espectro de las emociones humanas pero se elaboran desde una narrativa poética surgida del lenguaje cotidiano. Todo lo mencionado sin olvidar que dichas conexiones son un proceso particular en cada melómano, pues se trata de mirar los mecanismos que permiten la performatividad identitaria de los escuchas. Por consiguiente, el objetivo no es generalizarlas sino, precisamente, valorar su constitución singular en cada sujeto.

En el quinto y último epígrafe, a manera de conclusión, se refleja cómo la experiencia estética de la salsa y los diversos modos en que fue vivenciada aportaron significados en la vida de la gente que implicaron -e implican a día de hoy- mundos de sentido a través de la música. Con base en ello se da por sentado que la salsa y las interacciones con y en torno a ella son procesos vitales para sus públicos, tanto en lo privado como en lo social. Por lo tanto, se muestran las formas en que la corporeidad es atravesada por la salsa y, en conclusión, las experiencias performativas de los oyentes. Además, se observan los diferentes fenómenos de significado que los melómanos dan a la salsa. En otro plano, el capítulo evidencia los traspiés surgidos en el quehacer etnográfico, las soluciones propuestas $\mathrm{y}$, naturalmente, los aspectos que deben abordarse en las futuras investigaciones que se desprenderán de este proceso.

\section{Nota sobre el vocabulario y la escritura}

A lo largo de este documento, tanto en la escritura formal como en la testimonialcoloquial, se verá el empleo de distintos vocablos atribuidos al mismo concepto o a 
conceptos muy afines. Para comenzar, el de música tropical colombiana, el cual se encontrará a la vez como música costeña, música bailable, música de la Costa Atlántica o del Caribe colombiano. Salsa balada; entre cuyos múltiples sinónimos acopié: salsa rosa, romántica, erótica, motelera, de sábanas, de catre, de cama, de alcoba, porno-salsa, fácil. Salsa viejaguardera; salsa clásica, brava, dura, de golpe. Los términos «programador» $\mathrm{y}$ «Dj» se utilizarán indistintamente, puesto que mis fuentes así lo determinan. Puede haber una pequeña adición en las funciones del programador, y es que éste suele hacer programación radial. En ese caso se aclara cuando se refiere a esta actividad. De lo contrario, deben entenderse ambas voces con el mismo significado.

También es debido hacer una precisión sobre la escritura del nombre barrio y la palabra re-creación. En cuanto a barrio, cuando aparezca con artículo, en mayúsculas y en fuente cursiva (El Barrio), se hará referencia a lo que los portorriqueños y latinoamericanos inmigrantes en general bautizaron como la zona de influencia latina en Nueva York: Brooklyn, el East Harlem (El Barrio en sus inicios) y el South Bronx. Con respecto al término «re-creación», utilizo dicha escritura con el fin de que se entienda con el sentido de «volver a crear» y no con el significado usual de diversión o entretenimiento.

Para finalizar, trataré el conglomerado de estilos, ritmos o aires que cobija la salsa bajo la locución omnicomprensiva de género. Aunque el uso del término puede resultar controversial en algunas materias y razonable en otras, en esta tesis se usa porque resulta bastante operativo para trabajar con el conjunto de músicas que se adhieren a la voz «salsa». Aclaro que no pretendo sentar posición personal o académica alguna a favor del uso de la noción de género musical en este asunto y, en consecuencia, que tampoco tendrá lugar el análisis de la problemática que ello suscita en el presente texto.

\section{Nota sobre las traducciones}

Salvo indicación contraria, las traducciones son de la autora de la presente tesis doctoral. 


\section{CAPÍTULO I. EXPERIENCIA ESTÉTICA EN LAS MÚSICAS POPULARES URBANAS}

En este primer capítulo se abordan los conceptos teóricos más relevantes para el desarrollo de la presente tesis. Entre ellos se destacan los de experiencia estética y artefacto cultural, sujeto postmoderno, identidad e identificación, apropiación musical, narrativa y cuerpo y performatividad. Con ello pretendo sentar las bases teóricas que sustentarán el resto del trabajo. De importancia fundamental para determinar las interrelaciones entre salsa, subjetividad y socialidad es el concepto de estética. Entendida como condición de los individuos de apertura al mundo, permite comprender el entramado sígnico que se teje alrededor de la experiencia; pues el concepto de estética suscribe todo aquello que se percibe por los sentidos; el conocimiento que se adquiere a través de ellos. A partir de los preceptos estéticos se revela una red vinculante que pone en acción el cuerpo y la música, pues en calidad de artefacto cultural inmerso en la cotidianidad, define ciertas maneras de ser y de estar en la vida de sus oyentes dentro del contexto de las sociedades urbanas modernas. Por otra parte, el concepto de narrativa es vital para entender la organización de la experiencia en cada sujeto. A instancias del ejercicio narrativo de los escuchas salseros, observaremos la mediación del género musical en el sentido que imprimen a sus acciones y, por ende, en el relato identitario.

Como veremos más adelante, el qué sentimos o cómo sentimos en la música, o el qué significa o qué hace la música en un oyente es un punto neurálgico para identificar las relaciones entre subjetividad y experiencia estética inscritas en las prácticas de escucha. La salsa, en su calidad musical, es una expresión artística y puede ser analizada bajo los postulados filosóficos de la estética. Sin embargo, ese campo delimita su ejercicio analítico al «arte culto» que es un arte, en teoría, carente de propósito o función social, ya sea que devenga una autonomía de sentido o significado. Las músicas populares urbanas se conciben como músicas funcionales; es decir, producidas en el seno de una sociedad de consumo con unas prácticas determinadas de intercambio cultural. Esto las hace portadoras de unas funciones cotidianas específicas, razón por la cual no son predominantes para la tradición filosófica. Pero la salsa como artefacto cultural, popular y urbano, que suscitó un fenómeno masivo de apropiación musical en Nueva York, el Caribe y Latinoamérica, presenta implicaciones analíticas más plurales y complejas que 
las que aborda la tradición filosófica de la estética. Aquella apropiación ocasionó un ejercicio que desborda el marco de la contemplación, la experiencia y la reflexión del sujeto ante una obra de arte; premisa mayor de la estética filosófica. Ahora, es menester de ese campo abordar las experiencias estéticas en las músicas populares, ya que de igual forma constituyen a la estética como área de estudio.

En este camino, John Dewey ${ }^{8}$ nos brinda un desarrollo teórico que abarca el estudio de la experiencia estética, lejos de la preconizada concepción dieciochesca del arte como «lo bello y lo sublime» para dar paso a una estética pragmática que confiere al arte una función práctica. La estética pragmática considera la vida cotidiana como un marco de estesis, y considera a «todos» los sujetos como seres estéticos. Aquí la idea del objetoarte empieza a diluirse, pues genera un traspié epistemológico que impide avanzar en la comprensión de la experiencia estética y, más bien, repunta la idea de objeto-artefacto cultural. Éste es constituido en la práctica social y contribuye a su vez a la constitución de la misma práctica. La salsa per se es un artefacto que por añadidura se expande a otros elementos objetuales del tipo canciones, discos compactos o discos de acetato, o bien se extiende a ejercicios performativos como el baile y el canto. Desde esta perspectiva en la estética pragmática el artefacto cultural alberga una mediación decisivamente activa, y adquiere una importancia vital en las relaciones de las personas consigo mismas y con su entorno.

Por consiguiente, este análisis se sirve de la orientación de Dewey para identificar y comprender los mecanismos que intervienen en la construcción de subjetividades dentro del contexto de escucha y apropiación de la salsa. En toda esta reflexión, la salsa se presenta como un objeto de estudio de la estética pragmática con el propósito de analizar las experiencias que se producen en cuanto sus oyentes interactúan con ella. En ese sentido, la dimensión estética que interesa a este estudio atraviesa las prácticas de escucha del género, las cuales giran en torno a la vivencia del baile, la interpretación de las canciones o la escucha en la intimidad, por mencionar las más notables. En

\footnotetext{
${ }^{8}$ Arte como experiencia de John Dewey publicado en 1934 bajo el título Art as experience, es el primer referente de estudio sistematizado sobre una estética pragmática. Después, abordada y desarrollada por Richard Shusterman, abrió las puertas a la estética analítica que prontamente la desplazó. Sin embargo, en ese camino se dio paso al abordaje del arte como experiencia. En el libro Pragmatist Aesthetics. Living Beauty, Rethinking Art, Shusterman (2000), ilustra la idea de Dewey de ampliar la visión del arte a las artes populares, contemplando su dimensión ética y política y revisando las fronteras entre el arte culto y el popular; fronteras que no son tan rígidas como se daba por sentado. Un aspecto de denotada importancia es la inclusión del cuerpo en la estética, para lo cual retomó los postulados de Dewey y en el cual se encontró también con Foucault.
} 
consecuencia, otro aspecto de la obra de Dewey que interesa al estudio de los artefactos culturales es que contempla la operatoria de la estética desde la recepción:

« [...] la palabra "estético" se refiere, como ya lo hemos notado antes, a la experiencia, en cuanto a que es estimativa, perceptora y gozosa. Denota el punto del consumidor más que el del productor. Es decir, no solo es asunto de quién produce el artefacto sino de quien al percibirlo, lo aprecia o lo disfruta» ([1934] 2008, 54-55).

En este punto traigo brevemente a colación a Katia Mandoki ${ }^{9}$ para ilustrar una de las confusiones más comunes del juicio estético, que al ser despejada ayuda a aclarar la posición de la salsa dentro del juego estético y que se basa en señalar cómo el objeto de análisis es sustituido por la teoría que lo analiza:

[...] -recuerda el caso de los locutores que anuncian "problemas meteorológicos" (en su sentido literal problemas con el estudio de los meteoros) para referirse a problemas climáticos o atmosféricos-. Por ello es común que autores interesados en este tema hablen de los "objetos estéticos" -literalmente objetos sensibles o perceptivosqueriendo decir “objetos de o para la estética” (2006b, 15).

Bajo esta claridad considero la salsa un objeto para la estética; un objeto que media o es el puente para vivenciar una experiencia estética. Entonces, la estética referida a la experiencia que produce en los individuos se asume como la condición de estesis. Tal condición es natural en el ser humano; el cual se constituye como un sujeto sensible y perceptivo. Dada esta naturaleza estética de los sujetos, la estesis es concebida por Mandoki como la sensibilidad o condición de abertura o permeabilidad del sujeto al contexto en que está inmerso. Por eso concuerdo con la autora en que no tiene sentido el problema de la «experiencia estética» entendida como «la bella experiencia», ni tampoco la redundancia de «experiencia experiencial: el término estética proviene del

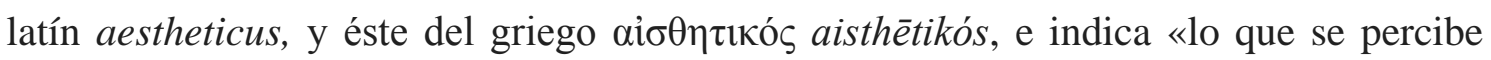
por los sentidos» («Real Academia Española» 2014); esto es la experiencia en sí misma, puesto que como condición de lo humano la estesis se presenta cuando el ser es expuesto al entorno, al mundo, en una completa y compleja sinergia experiencial y no únicamente en momentos determinados de «contemplación estética».

\footnotetext{
${ }^{9}$ Esta artista y académica mexicana es una de las más prolíficas estudiosas sobre la estética en la sociedad contemporánea. Son muy connotados sus trabajos sobre estética pragmática, estética, poder y estado, y estética e identidad. De la primera tendencia destacan las obras: Prácticas estéticas e identidades sociales: Prosaica II (2006b). Estética cotidiana y juegos de la cultura: Prosaica I (2006a).
} 
Cabe reiterar que la aproximación al presente estudio estético de la salsa asume el género musical no como un dispositivo artístico sino como un artefacto cultural. Con esa orientación es fundamental el abordaje de Mandoki que recoge los postulados de John Dewey y Richard Shusterman para abordar la estética aplicada a la cotidianidad. Aquí se hace a un lado la aplicación centrada en el «arte» o «lo bello». La estética cotidiana se enmarca dentro de lo que se define como socio-estética: «los procesos de estesis en el seno de la vida social» (Mandoki 2006b, 16), donde uno de los elementos de intercambio simbólico entre las personas es la música. La socio-estética contempla dos tipos de estudio del artefacto cultural a los que denomina Prosaica y Poética. En la Prosaica el arte es visto como práctica social en la vida cotidiana, de manera que existe una Prosaica del arte. En la Poética se acudiría rigurosamente al «examen de la obra artística desde el interior, con sus propias reglas e idiolectos de configuración» (2006b, 16). La salsa en esta tesis es abordada en su mayor parte desde la Prosaica:

\footnotetext{
Entendemos, pues, a la Prosaica como la teoría de las sensibilidades sociales y del papel de la estesis en las estrategias de constitución de intercambio de identidades individuales y colectivas. Otra manera de demarcar a la Prosaica es como la exploración de actividades estéticas materializadas en procesos de construcción de realidades matriciales y sus respectivas identidades (Mandoki 2006b, 16).
}

\subsection{El artefacto cultural en el ejercicio de la estética}

En la revisión de la experiencia con el género, la concepción de la música popular como artefacto cultural resulta bastante operativa en el intento por describir los ejercicios de la estética. El vocablo «artefacto» remite a ars, del latín, que es la traducción del griego $\tau \varepsilon ́ \chi v \eta$ téchne, en el sentido de algo producido mediante la aplicación de una técnica. Este algo es un utensilio mientras tenga una utilidad para alguien. Cuando el objeto se desgasta solo queda su habitualidad; el hábito de su uso. El asunto de la «cosidad» de las cosas y de la habitualidad que generan los usos, desarrollado en principio por Heidegger, da cuenta de la irreductibilidad de la condición material que tienen los objetos, por un lado y por otro, de la costumbre que nos queda de su uso; del poner en práctica algo con ellos. 
La música también debe entenderse como un objeto que convoca multiplicidad de funciones; no una en específico, pero que no se agota. Ésta es la condición sine qua non del «artefacto cultural»: no se reduce a su instrumentalidad. Estos artefactos tienen o pueden tener utilidad, pero ésta no agota su existencia; pueden asimismo alcanzar habitualidad, pero no al punto de reducirse a una pura materialidad [...]. En el artefacto cultural la materialidad se vuelve subsidiaria de su «poner en obra la cultura» (Isava 2009, 444-45). Por consiguiente, en el análisis de las relaciones entre salsa y significado me sirvo del término artefacto para expresar la forma en la cual, por intermedio de la salsa, se ponen en funcionamiento diversas redes de sentido y de significación que nos permiten interpretar la cultura. De hecho, éste es el aporte más importante que nos brinda el término «artefacto cultural»: leer la puesta en marcha de la cultura a través de sus artefactos. No podría expresarlo con más precisión que la de Clifford Geertz cuando señala:

[...] asumiendo, con Max Weber, que el hombre es un animal suspendido en redes de significación que él mismo ha tejido, considero que la cultura es esas redes y que su análisis es, por tanto, no una ciencia experimental en busca de una ley, sino una interpretación en busca de un sentido $(1973,5) .{ }^{10}$

No obstante, a partir de las apreciaciones anteriores se constata que la salsa es material para la estética y es, asimismo, material para la construcción de otro tipo de sentidos. En los estudios de las músicas populares se reconoce que su composición semiótica y su naturaleza polisémica afrontan nuevas perspectivas analíticas. Por lo tanto, el presente estudio acoge las consideraciones de Simon Frith ([1987] 2008), Richard Middleton (1990), Pablo Vila (1996) y Tia DeNora (2000), entre otros, que entienden que el artefacto cultural, y en específico la música, contiene «materiales semióticos»; esto es, materiales que bien sean lingüísticos, tecnológicos o estéticos, son susceptibles de significar o significarse. DeNora, por ejemplo, toca una cuestión sustancial al poner sobre la mesa la discusión en torno al significado. Se interroga sobre la significación autónoma de estos materiales, aunque reconoce que tampoco están totalmente vacíos de significado. Sin embargo, desde la lectura de los autores mencionados y el avance en la comprensión del papel que juega la música en las personas, su cuestionamiento recae en

\footnotetext{
10 «Believing, with Max Weber, that man is an animal suspended in webs of significance he himself has spun, I take culture to be those webs, and the analysis of it to be therefore not an experimental science in search of law but an interpretive one in search of meaning».
} 
que los estudios de los artefactos culturales deben centrarse más en lo que éstos «hacen» que en lo que «significan».

También da por sentado que los elementos semióticos no funcionan por sí solos y hace hincapié en «cómo las personas, los significados y las cosas se juntan en escenas particulares socialmente localizadas. Esta perspectiva deja espacio para la negociación y renegociación en curso de los significados de las personas [que construyen], las cosas y las situaciones» ${ }^{11}$ (DeNora 2000, 38). A través de un juego lingüístico sugiere no tratar el artefacto y la relación con el actor en forma separada, como dos ejes distintos, sino que utiliza el término ‘artefact-actor’ para determinar estratégicamente la interrelación entre la gente y las cosas.

Por esta razón, las preguntas más interesantes sobre las implicaciones sociales de artefactos (ya se trate de tecnologías, expresiones o materiales estéticos tales como la música) se centran en el nivel de interacción donde las articulaciones - enlaces - entre los seres humanos, escenas y ambientes se producen realmente, y donde las estructuras del orden llegan a ser estabilizadas y desestabilizadas en tiempo real (DeNora 2000, 40). ${ }^{12}$

Alude, además, a la premisa de que «cuando se habla de una cosa, se constituye esa cosa»; de esta manera, cuando se habla de la música se está «constituyendo» la música. Para DeNora el material semiótico no actúa de forma netamente autónoma, sino que la gente constituye su fuerza semiótica desde necesidades de significación particulares. La salsa en Colombia es un ejemplo muy propicio: dado que ya se ha estabilizado la significación la salsa es alegría, normalmente, la gente acude a ella para sentirse alegre. Es decir, se ha impuesto una fuerza semiótica debido a una construcción colectiva del género musical; la gente ha invertido el significado de la alegría y ha dotado a la salsa con ese poder. Como veremos más adelante, hay contradicciones, y en la evolución de usos y funciones individuales y sociales, el concepto de alegría, a veces, se desvanece, aunque no deja de ser un cliché asociado a este género musical.

\footnotetext{
${ }^{11}$ «... the ways in which people, things and meanings come to be clustered within particular socially located scenes. Such a perspective leaves space for the ongoing negotiation and renegotiation of the meanings of people, things and situations».

${ }^{12}$ «For this reason, the most interesting questions concerning the social implications of artefacts (whether these are technologies, utterances or aesthetic materials such as music) focus on the interactional level where articulations - links - between humans, scenes and environments are actually produced, and where frames of order come to be stabilized and destabilized in real time».
} 
Pese a esto, es algo complejo generalizar la constitución de la significación musical en términos de DeNora. Su previsión implicaría que la experiencia estética, y otro tipo de experiencias que invoquen sentido en la gente, no solo conllevan articulaciones contextuales del tipo «situación de escucha, sedimentaciones históricas de determinada obra, el rol de la música en la biografía personal de cada escucha, la configuración técnica del sonido resultante en el matiz emocional de las estructuras», entre otros, sino que las personas elegirían autónomamente la función estética del material sonoro. Ello conllevaría que la experiencia esté intervenida por articulaciones de significación que las personas autónomamente invierten en dicho material. Si bien esto es normal en un oyente habituado a determinado tipo de escucha, tal declaración limitaría algunas posibilidades de interpelación del sonido.

Claramente, el sentido de las cosas siempre se negocia y los individuos establecen sus propias sujeciones, pero dada la naturaleza de la estesis no siempre, en principio, puede negociarse la significación. Me refiero estrictamente a los oyentes neófitos de un género. Algunos melómanos salseros en Colombia comentan que empezaron a escuchar salsa por la motivación colectiva de la rumba y el disfrute. Los que perseveraron en la escucha y el rastreo de información sobre la música desarrollaron otras maneras de vivirla $\mathrm{y}$, de hecho, encontraron otros sentidos en las prácticas con el género. Pero muchos se adhirieron a la interpretación habitual y normalizada del goce en las andanzas fiesteras, por lo que la única razón para interactuar con la salsa es la rumba. Así que es una negociación de sentido predeterminada por las convenciones del uso social y no adquirió ningún desarrollo diferente en ese grupo. Sin embargo, el tipo de salsero que encontró distintos usos y funciones en la salsa se enmarca en la propuesta de DeNora al invertir significaciones particulares y autónomas en la música; al conferirle unos poderes específicos que obedecen netamente a necesidades individuales, como observaremos más adelante en la construcción individual de mundos de sentido.

También es interesante en su reflexión el estudio de la música a través de la experiencia de las personas; pues alude directamente a la recepción musical y a las prácticas de consumo de los géneros musicales que apenas empiezan a abordarse desde las perspectivas etnográficas. Esta visión es muy apropiada en esta clase de estudios y los testimonios personales han sido un pilar fundamental para comprender las relaciones entre la subjetividad, el cuerpo y la salsa. No obstante, el problema con el postulado de la autora es que, en cierto modo, plantea entender la significación por medio de la 
verbalización de los informantes. Obviamente, éste es el ideal etnográfico, pero las elaboraciones discursivas en el melómano nunca están en primer plano porque, por un lado, no afectan en primera instancia a la experiencia y, por otro, porque la verbalización depende del bagaje y formación de los oyentes; de su nivel lingüístico. De todas formas, arriesgar una exégesis sobre la experiencia estética es plausible con los desarrollos teóricos que se van dando en el campo de las músicas populares y adentrarse en su constitución es definitivo para seguir comprendiendo el rol de la música en los procesos estésicos.

Se entiende, entonces, que la estesis se produce en las personas y que los artefactos son objetos con determinados contenidos que median el proceso experiencial. La percepción y la sensibilidad se conjugan para acondicionar o disponer la circunstancia o coyuntura de la estesis en cuanto una persona capta sensorialmente todos los elementos que integran los fenómenos del mundo exterior que la circunda. Cuando la música entra en contacto con el oyente y lo interpela es cuando se funda la experiencia estética, aunque no hay que descuidar que hay unas cargas simbólicas asociadas a la escucha y unas condiciones en el oyente y en el entorno que articulan los materiales semióticos de los artefactos con la experiencia misma. Aquí se presenta una realidad irreducible: la experiencia estética ocurre en el receptor y, por ende, interviene el lugar y el ambiente que está habitando o viviendo en un momento determinado. De esta forma, los estudios de DeNora muestran las formas en que la música actúa como tecnología del yo, como tecnología del cuerpo y como dispositivo de regulación de interacciones en la vida cotidiana.

De este modo, concibo que la salsa, más su expansión en objetos tangibles, sobre todo discos de acetato en la salsa viejaguardera, es un artefacto cultural con un ancho potencial semiótico. Dicho potencial no solo afecta a la experiencia estética sino, además, a la experiencia social llegando a influir para algunos, incluso, sobre la experiencia de vivir la ciudad. En el contexto vital del melómano la salsa como artefacto cultural y las disposiciones a su alrededor -escucha, adquisición, colección, rumba, encuentros, programación, búsqueda de información o, incluso, comercialización-, tienen atribuciones estratégicas en lo concerniente a la elaboración del cuerpo, la autorregulación emocional, las posiciones que asumen los sujetos en los escenarios sociales y la construcción de subjetividad e identidad. DeNora escribe: «Es curioso, entonces, que la música -probablemente el material cultural por excelencia de 
la emoción y lo personal- no haya sido explorada en relación con la constitución del yo» ${ }^{13}(2000,46)$. Por eso consideramos que el artefacto cultural permite a la gente hacer cosas significantes y, en conclusión, puede regular la construcción del «yo» postmoderno, sin identidad fija, inevitablemente descentrado o a la vez con múltiples y dinámicos centros de sujeción identitaria.

\subsection{Subjetividades postmodernas y apropiación musical}

La experiencia estética abarca una relación inalienable con la fundación de la subjetividad al inaugurar uno de los vínculos sujeto-identidad. El término identidad es problemático en tanto continúa inscribiendo al individuo en una serie de rasgos esencialistas. Stuart Hall expone precisamente la crisis de la identidad en el postmodernismo; se han abandonado las teorías «esencialistas» que establecían una identidad «unificada», «estable» y «centrada» que partía de un «yo que ya es y sigue siendo siempre el mismo», idéntico a sí mismo a lo largo del tiempo (Hall 1996a, 17). De ahí que una nueva definición resulta urgente debido a que ese sujeto centrado, estable y unificado ha desaparecido dando paso a un individuo de subjetividad fragmentada, de identidades múltiples; ya no es el sujeto del conocimiento artífice de cualquier posible relación. Es esa pretendida autonomía la que ha hecho crisis, convirtiéndose en rechazo a la razón totalizadora y a su sujeto: el cogito en el que se funda la modernidad (Martín-Barbero 2003).

En la historia de la objetivación del sujeto Hall encuentra tres momentos: El sujeto de la ilustración, individuo dotado de las capacidades de razón, conciencia y acción, considerado una sustancia inmutable con una identidad como esencia fija y dada; en resumen, el llamado sujeto cartesiano. Luego aparece el sujeto sociológico cuyo núcleo interior no era autónomo y autosuficiente, sino que se formaba en la relación con otros sujetos constituyendo una identidad en la relación entre el yo y la sociedad. Finalmente, un sujeto postmoderno sin identidad fija o permanente, una identidad móvil que se «forma y transforma continuamente en función de los modos en que somos representados o interpelados en los sistemas culturales que nos rodean. El sujeto asume

\footnotetext{
${ }^{13}$ «It is curious, then, that music - arguably the cultural material par excellence of emotion and the personal - has not been explored in relation to the constitution of self».
} 
diferentes identidades en momentos distintos, identidades que no están unificadas en torno a un “yo” coherente» (Hall 2010b [1992], 365).

En concordancia con la modernidad, Michel Foucault estudió las formas en que el ser humano se ha convertido en sujeto a través de la historia; las formas en que ha sido objetivado desde el lenguaje, desde la productividad o, incluso, desde la biología. Posteriormente, cómo ha sido subjetivado desde la exclusión a causa de la diferencia asumida desde la oposición que implanta la peligrosa racionalización: el loco, el enfermo, el delincuente. El final de este recorrido enfoca un sujeto que trata de constituirse a sí mismo, que lucha contra las sujeciones impuestas, contra las formas estatutarias en que ha sido individualizado, y que es indefectiblemente el sujeto de la modernidad:

Sin duda el objetivo principal en estos días no es descubrir lo que somos, sino rechazar lo que somos. Tenemos que imaginar y construir lo que podríamos ser para librarnos de este tipo de "doble atadura" política, que consiste en la simultánea individualización y totalización de las estructuras del poder moderno.

Podría decirse, como conclusión, que el problema político, ético, social y filosófico de nuestros días no consiste en tratar de liberar al individuo del Estado, y de las instituciones del Estado, sino liberarnos del Estado y del tipo de individualización vinculada con él. Debemos fomentar nuevas formas de subjetividad mediante el rechazo del tipo de individualidad que se nos ha impuesto durante varios siglos (Foucault 1988, $11)$.

Es en tal circunstancia donde los artefactos culturales adquieren importancia como soporte de nuevas subjetividades, donde promueven esa necesaria y decidida movilidad del yo entre posiciones sociales. Puede que surja ahora un interrogante que considere si tales configuraciones subjetivas son inconscientes o autónomas, pero me detendré en lo que la música hace o significa cuando ya está inscrita en la vida de la gente. En conclusión, este sujeto postmoderno en crisis, descrito por Hall, y ese sujeto que lucha contra la sujeción, descrito por Foucault, son el modelo desde el cual se extenderá la problematización de la experiencia musical y, a partir de aquí, el andamiaje de sus mundos de sentido en torno a la escucha de la salsa.

En este punto hay que señalar decididamente que la salsa es un buen resumen de la postmodernidad; nada más apegado a una definición de lo postmoderno que la salsa. El 
caos neoyorquino que la originó, la manera festiva y catártica en que la recibieron sus audiencias más la impronta reivindicatoria o revolucionaria con que fue asumida, expresan la crisis de los sistemas de significación en el postmodernismo ante la cual Simon Frith se pregunta:

¿Cómo podemos notar hoy la diferencia entre lo «real» y lo «simulado»? El problema posmoderno es la amenaza a nuestra idea de lugar, de ahí las metáforas cartográficas, el uso de términos como profundidad y superficie. En esas discusiones se minimiza el problema del proceso: no el posicionamiento del sujeto como tal, sino nuestra experiencia del movimiento entre posiciones. Ese es el punto en que la música se convierte en una importante área de estudio: ¿qué pasa con nuestros supuestos sobre la identidad posmoderna cuando examinamos una forma en la cual el sonido es más importante que la vista, y el tiempo más importante que el espacio; cuando el «texto» es una ejecución, un movimiento, un flujo; cuando no «se representa» nada? (Frith 1996, 184-85).

La metrópoli latinoamericana postmoderna -con su respectivo desorden- encuentra resonancias con la manera en que se desarrolla la salsa, la cual porta, desde cierto punto de vista, una dislocación con los modelos de preservación del orden (característica que no se relega a la salsa, ya que se presenta a su vez en otros géneros musicales disruptivos de lo social en el siglo XX, como el rock, el punk o el rap). ${ }^{14}$ Por consiguiente, la crisis de los sistemas de significación que se verifica en el pensamiento postmoderno, se refleja con profunda precisión en la salsa de corte viejaguardero y en las relaciones que los sujetos tejen a su alrededor. De esta forma, dicha ruptura con el canon presente en la salsa, ha servido para que el melómano pueda establecer escenarios de actuación que son controlados por él mismo, y resbalan al poder de las instituciones o del otro.

Por otra parte, así como la concepción del sujeto ha ido mutando de acuerdo con las contingencias históricas y algunos significados antes que estabilizarse han colapsado, en pro de un tratamiento más práctico esta tesis asumirá además el término de identificación. La música ha sido un determinante de identidad, algo que es real pero

\footnotetext{
${ }^{14}$ Richard Shusterman $(2000,202)$ asevera que el rap es uno de los géneros que con mayor intensidad representa lo que es la música popular postmoderna. Enuncia que en el postmodernismo la estética «se resiste a una definición clara e inquebrantable» y antes que buscar la creación original, ésta devenga una tendencia hacia la mezcla ecléctica de estilos, la apropiación, el reciclaje, las nuevas tecnologías y la cultura de masas, entre otras.
} 
que en ocasiones ha sido tan impreciso como falaz; ante todo si nos remitimos a los usos políticos en el afán de homogenizar o establecer unidad. Verbi gratia las categorías que sitúan correspondencias identitarias muchas veces imaginadas o convenientes al poder del estado o a las fracturas etarias; entre ellas: las músicas nacionales, las músicas de los jóvenes, las músicas de los viejos. Por consiguiente, mientras la identidad se arroga como algo acabado y cerrado, la identificación es un proceso inacabado:

La identidad se yergue, no tanto de una plenitud de identidad que ya está dentro de nosotros como individuos, sino de una falta de totalidad, la cual es "Ilenada" desde fuera de nosotros, por medio de las maneras en que imaginamos que somos vistos por otros. Psicoanalíticamente, la razón por la cual estamos en continua búsqueda de “identidad”, construyendo biografías que unen las diferentes partes de nuestros “yos”, es para volver a captar este placer fantaseado de completitud (plenitud) (Hall [1992] 2010b, 376).

Ahora, igualmente se adviertan confusiones e imprecisiones con el término identificación, porque plantea que «la cuestión de la identificación, se reitera en el intento de rearticular la relación entre sujetos y prácticas discursivas» (Hall 1996b, 15). No obstante, Hall retoma de los usos funcionales del concepto su propiedad procesual, condicional y contingente. La identificación se afirma en el reconocimiento de algo en común con otros o con un ideal (1996a, 15). Esta practicidad adquirida en el uso de la lengua la hace un elemento eficiente al hablar sobre la música; sobre cómo nos constituye la música o cómo se constituye la música en nosotros. Al preguntar a la gente sobre sus gustos musicales, por ejemplo, es normal la remisión a: «me identifico con» tal canción, tal artista o tal tipo de música, y nos es claro que dicha identificación está ligada a las condiciones del momento en que se ha apropiado en términos de artefacto cultural.

Aunque no carece de condiciones determinadas de existencia, que incluyen los recursos materiales y simbólicos necesarios para sostenerla, la identificación es en definitiva condicional y se afinca en la contingencia. Una vez consolidada, no cancela la diferencia. La fusión total que sugiere es, en realidad, una fantasía de incorporación. [...] La identificación es, entonces, un proceso de articulación, una sutura, una sobredeterminación y no una subsunción. Siempre hay «demasiada» o «demasiado poca»: una sobredeterminación o una falta, pero nunca una proporción adecuada, una totalidad (Hall 1996a, 15). 
Siguiendo el desarrollo del concepto, Simon Frith expone: «La identidad no es una cosa sino un proceso: un proceso experiencial [...]» ([1996] 2003, 185). Si bien todo proceso de identificación o toda construcción de identidad no es únicamente un proceso de experiencia, podemos delegarle a la música, y con certeza, la construcción de subjetividades en la estesis sonora. Al concebir que la experiencia estética interviene la subjetividad y la realidad de una persona, entonces, en concordancia con Josep Martí diremos que la música es una herramienta que contribuye a generar realidad $(2000,10)$, y relacionarla con las teorizaciones identitarias y la subjetividad es inevitable. En la experiencia estética de las músicas populares Frith ([1996] 2003, 184) invierte el argumento: «lo estético describe la calidad de una experiencia (no la de un objeto); significa experimentarnos a nosotros mismos (no sólo el mundo) de una manera diferente», atribuyéndole a la estética la capacidad de transformar el «yo».

Por consiguiente, para entender el rol de la salsa en la producción de subjetividad en los melómanos bogotanos, se utilizarán dos conceptos acogidos por la investigación en música de estas últimas décadas: interpelación y articulación; desarrollados por Stuart Hall, Simon Frith, Richard Middleton y Pablo Vila, entre otros. El primero, «interpelación» ${ }^{15}$ es el fenómeno que ocurre cuando un individuo es exhortado por algo; en este caso la música, pero es algo que va mucho más allá del efecto estímulo y reacción y no es unidireccional, ya que la interpelación actúa en una circunstancia definida por múltiples factores. Middleton lo llama «dialéctica interpelativa», y lo define en los siguientes términos:

No elegimos, entonces, nuestros gustos musicales libremente, ni ellos reflejan nuestra ‘experiencia’ de una sola forma. La implicación de los sujetos en los particulares placeres musicales, ha sido construida; de hecho, es parte y parcela de la producción de subjetividad. En este proceso, los sujetos por sí mismos - no obstante 'descentrados' tienen que jugar un rol (de reconocimiento, aprobación, rechazo, comparación, modificación); pero esto es una articulación, no simplemente un rol creativo o

\footnotetext{
${ }^{15}$ Louis Althusser utiliza el concepto de interpelación para explicar la formación o construcción de los sujetos sociales. Lo define como una operación mediante la cual la ideología «actúa» o «funciona» de tal modo que «recluta» sujetos entre los individuos (los recluta a todos), o «transforma» a los individuos en sujetos (los transforma a todos) por medio de esta operación muy precisa que llamamos interpelación, y que se puede representar con la más trivial y corriente interpelación, policial (o no) «iEh, usted, oiga!» Si suponemos que la hipotética escena ocurre en la calle, el individuo interpelado se vuelve. Por este simple giro físico de 180 grados se convierte en sujeto. ¿Por qué? Porque reconoció que la interpelación se dirigía «precisamente» a él y que «era precisamente él quien había sido interpelado» (y no otro). (Althusser 1970).
} 
receptivo. Los sujetos participan en una 'dialéctica interpelativa', y ésta toma formas específicas en áreas específicas de la práctica cultural (Middleton 1990, 249). ${ }^{16}$

El segundo, «articulación» ${ }^{17}$, referido a «la manera en que se conectan dos elementos diferentes, bajo ciertas condiciones». Recogiendo las observaciones de David Harvey y Ernesto Laclau, Hall (1996) define que la articulación es una conexión o encadenamiento; es un punto de sutura que subsana rupturas o empalma dislocaciones con condiciones históricas precedentes, o que hace suturas entre fragmentaciones y rupturas sociales presentes. Por eso no a todas las personas de un grupo les gusta la misma música, o de una determinada música les gustan los mismos elementos. Las interpelaciones van acompañadas de factores que hacen posible la articulación de sentido en cada individuo en particular. Preguntando sobre las voces de la salsa, algunos oyentes enfatizaban en la interpelación de determinadas vocalidades en ellos, pero para otros, las voces no eran tan importantes. Algunos esgrimían que lo importante eran las líricas, mientras que otros hablaban más de los timbres pese a que no se acordaban mucho de las letras. Una oyente ponía en primer plano la voz de Tony Molina, y ella misma afirmaba que quizás sentía ese enganche a su voz porque conoció a Molina en persona y él asistió a su fiesta de cumpleaños en su propia casa en Colombia.

Frith identifica una de las interpelaciones más categóricas de la música, en el poder singular que tiene para la ubicación individual y colectiva de los sujetos debido a su «directa intensidad emocional». Agrega además: «usamos las canciones del pop para crearnos a nosotros mismos una especie de autodefinición particular, para darnos un lugar en el seno de la sociedad. El placer que provoca la música pop es un placer de identificación -con la música que nos gusta, con los intérpretes de esa música, con otras

\footnotetext{
${ }^{16}$ «We do not, then, choose our musical tastes freely; nor do they reflect our 'experience' in any simple way. The involvement of subjects in particular musical pleasures has to be constructed; indeed, such construction is part and parcel of the production of subjectivity. In this process, subjects themselves however 'decentred' - have a role to play (of recognition, assent, refusal comparison, modification); but it is an articulatory, not a simplistically creative or responsive role. Subjects participate in an 'interpellative dialectic', and this takes specific forms in specific areas of cultural practice».

${ }^{17}$ Según Hall: «Con el término "articulación” me refiero a una conexión o un vínculo que no se da necesariamente en todos los casos como una ley o un hecho de la vida, sino que requiere condiciones particulares de existencia para aparecer, que tiene que ser sostenido positivamente por procesos específicos, que no es "eterno" sino que tiene que ser renovado constantemente, que puede bajo algunas circunstancias desaparecer o ser desplazado, llevando a los antiguos vínculos a ser disueltos y a las nuevas conexiones -rearticulaciones- a forjarse. También es importante que una articulación entre diferentes prácticas no significa que se vuelvan idénticas o que una se disuelva en la otra. Cada una retiene sus determinaciones distintivas y las condiciones de su existencia. Sin embargo, una vez que se forma una articulación, las dos prácticas pueden funcionar juntas, no como una "identidad inmediata”, en el lenguaje de la Introducción de 1857 de Marx, sino como "distinciones dentro de una unidad”» (2010, 195).
} 
personas a las que también les gusta-» (Frith [1987] 2008, 421-22). Aunque no acude a una postura teórica para definir la experiencia estética y pareciera relegar el papel de la estesis al asunto del gusto o del disgusto por una música, coincido en el argumento de la identificación. Pero hay que aclarar que no solo es un placer de identificación con el estilo, sino con los elementos que pueden sustraerse del mismo a la vida cotidiana. Por ejemplo, algunos recursos musicales característicos de un género circulan en distintos géneros; en la salsa, los mismos oyentes pueden improvisar pregones o décimas, entre otras traducciones o transposiciones posibles.

Así pues, observamos que las interpelaciones en las músicas populares nacen, también, en la facilidad con que éstas pueden ser manipuladas: son cantables y danzables o son recitables; sus rítmicas y melodías son aprehensibles y transformables, sus letras resuelven cabalmente las necesidades de expresión y comunicación de las personas. Es decir, aportan un mecanismo de apropiación eficiente. No obstante, los procesos de apropiación no son siempre generalizables, los sujetos negocian el sentido en sus prácticas con los géneros. Pablo Vila sostiene:

La música para nosotros sí tiene sentido (no intrínseco, pero sentido al fin), y tal sentido está ligado a las articulaciones en las cuales ha participado en el pasado. Por supuesto que estas articulaciones pasadas no actúan como una camisa de fuerza que impide su rearticulación en configuraciones de sentido nuevas, pero, sin embargo, sí actúan poniendo ciertos límites al rango de articulaciones posibles en el futuro. Así, la música no llega "vacía", sin connotaciones previas al encuentro de actores sociales que le proveerían de sentido, sino que, por el contrario, llega plagada de múltiples (y muchas veces contradictorias) connotaciones de sentido (1996 s.p.).

Cuando hablamos de la apropiación de la salsa en Colombia, precisamente, observamos que no llegó vacía de connotaciones. No solo llevaba unos registros de la vida en Nueva York familiares con las problemáticas de las ciudades latinoamericanas del siglo XX, sino también unas conexiones musicales con los aires y ritmos caribeños que afloraban en la música tropical de la Costa Atlántica colombiana; asunto que veremos en el siguiente capítulo. En efecto, notamos que el background del género tuvo una amplia injerencia en el estatus identitario de sus audiencias en el país, conllevando un engranaje de articulaciones determinantes para su asentamiento en el territorio. 


\subsection{Identificaciones colectivas $\mathrm{e}$ individuales}

Las prácticas alrededor de las músicas populares invocan indefectiblemente la cuestión de la colectividad. La eclosión del fenómeno salsero estuvo política, histórica y socialmente afectada por el marco sociocultural donde se produjo: en Estados Unidos, en el seno de una comunidad minoritaria y marginada de inmigrantes latinoamericanos, que pugnaba por la construcción de un territorio propio desde el cual dar sus batallas reivindicatorias. ${ }^{18}$ En la mezcla de las poblaciones latinoamericanas migrantes no hay que olvidar que el componente negro tuvo una presencia destacada y que, al igual que los afrodescendientes de Estados Unidos, los latinos y los afro latinos eran objeto de discriminación. La grave problemática que de ello se desprendía ponía a estas comunidades en el epicentro de un conflicto en el cual la música era mucho más que un catalizador emocional. La música era un artefacto que mediaba en la construcción de mundos de sentido y facilitaba el permanecer en un lugar extraño, combatiendo el desarraigo y la nostalgia por la lejanía del territorio de origen de los migrantes.

En este orden de ideas, la recepción de la música en el tránsito por el Caribe y Latinoamérica implicó un hecho social trascendental. La música ha tenido entre sus múltiples funciones la de ser bastión de movimientos sociales, culturales y políticos y, al mismo tiempo, ha sido soporte de los discursos y la emocionalidad de nacionalismos y revoluciones. La música, como hecho social, pone en primer plano el asunto de la recepción en conjunto, de la vivencia de la música en grupo y, por ende, de la adscripción colectiva a determinadas expresiones de la cultura. Alejandro Ulloa defiende la tesis de que el surgimiento de la salsa, como tal, en su condición urbana y su contexto neoyorquino, engendró «el imaginario de la latinidad en vez de la cubanidad» (2009, 269). ${ }^{19}$ Bajo este panorama, la salsa constituyó ante todo -y aún lo hace- lugares

\footnotetext{
${ }^{18}$ Por cierto, la nómina de músicos, cantantes o productores no era estrictamente latina. Ulloa (2009, 275) enumera un representativo colectivo de participantes de diversas nacionalidades, asentados en territorio estadounidense.

${ }^{19}$ El imaginario de la «cubanidad» que Ulloa supone en ese aparte de su libro La salsa en discusión, y que subtitula «Las innovaciones de la salsa y la construcción de un relato identitario», es un poco extraño en tanto los músicos que menciona son de origen portorriqueño, cubano o dominicano entre otros. Más apropiado sería tratarlo como el imaginario de lo «caribeño». Por otra parte, aunque la salsa comparte afinidades con otras músicas latinoamericanas, se antoja un poco grandilocuente su tratamiento de la «latinidad», abarcadora de todo el cono sur. Al menos en principio, en palabras de Santamaría-Delgado «la construcción de latinidad neoyorquina refería las comunidades de la diáspora de las islas del Caribe que llegaron allí como resultado de las intervenciones imperiales de Estados Unidos en la región. En otras palabras, allí no había ni mexicanos, ni argentinos, ni colombianos, por lo menos no en un principio. Eran cubanos, puertorriqueños y dominicanos. Y un panameño, Rubén Blades, [...] pero ese imaginario latino funciona en las comunidades hispanas de EEUU y en los discursos caleños, pero no aplica para
} 
de encuentro; lugares de colectividad en los que es posible amalgamar componentes raciales, religiosos, históricos y culturales:

Si con las alusiones a los orichas de la «Santería» afrocubana se enriquecía una «cosmovisión politeísta» por el énfasis puesto en la etnicidad afrocaribeña y su religiosidad, con el canto en lengua castellana se promovió una idea del ser latino y la latinidad. Era esta una identidad diferenciada, frente a la sociedad norteamericana, unificada por el idioma que incluía también al negro como es descrito en tantas composiciones. Tomamos como referencia «Las caras lindas de mi gente negra», compuesta por Tite Curet Alonso. La canción, creada por un negro y cantada por un mulato como Ismael Rivera, es un contundente mensaje de afirmación étnica y asertividad en un medio decididamente racista. Creemos que por su melodía, su inspiración poética, su carácter bailable y su difusión masiva ante millones de oyentes, esta canción ha contribuido en el mundo latino, más que cualquier otro discurso político, a la reivindicación de los afrodescendientes y a la democracia racial que tanto necesita el mundo (Ulloa 2009, 275-76). ${ }^{20}$

A partir de la noción de «latinidad» que defiende Ulloa se hace patente la de «otredad», vista desde la exclusión del inmigrante latino que, a fuerza de desarraigo y desamparo, elabora un imaginario de hermandad:

En muchas de las canciones, la salsa promovió dicha representación, [de la hermandad y la identidad latina] a través de un relato verbal acompañado de ritmo y melodía; en una de sus vertientes fortaleció un sentido colectivo, gracias a los mensajes que interpelaban a esa comunidad procedente de diversos países caribeños y latinoamericanos con vínculos comunes, problemas semejantes y esperanzas compartidas.

Lo nuevo estaba también en aquella camada de músicos jóvenes «la generación del 30» interesados en el despertar de una conciencia latinoamericana («anti-imperialista» inclusive, por lo menos en algunos) que una parte de la salsa llegó a representar. Una conciencia de integración y unidad latina (que ha tenido también sus detractores y mercaderes) pero que en sus líneas más importantes ha conservado en alto esta bandera contra viento y marea o contra la ignorancia de muchos productores de la industria, y de programadores radiales interesados únicamente en el carácter mercantil de la música... y en la payola (Ulloa 2009, 276-77).

uruguayos, paraguayos, chilenos, bolivianos, etc. Si bien creo que el imaginario de latinidad puede ser aplicable para Colombia, creo que no es abarcador sino que engloba principalmente a los de la Cuenca del Caribe» (Santamaría-Delgado 2016, comunicación personal).

${ }^{20}$ El tema de Curet Alonso se encuentra disponible en https://www.youtube.com/watch?v=K8yIqoQ1LpI. 
Evidentemente, la música popular es un artefacto de identificación de capital importancia, y dicha función se soporta cuando el género en cuestión está también constituido por líricas que refuerzan mensajes específicos, como el caso de la canción de Curet $^{21}$ expuesto por Ulloa. Veíamos anteriormente en Frith ([1987] 2008, 422), la valía de la música como respuesta a cuestiones de identidad, y en el caso de la salsa son bastantes las remisiones a un ser latino, a un colectivo, a una hermandad entre pueblos vecinos que comparten circunstancias similares, por decirlo de alguna forma. Por eso se puede entender la eficiencia de la salsa para interpelar identidades. Por otra parte, es interesante comprender por qué dentro de un mismo grupo social en el cual todos sus integrantes ocupan posiciones semejantes, ciertos estilos interpelan a unos pero no a otros; o cuando todo el grupo se apropia del estilo, por qué sus integrantes son interpelados por elementos diferentes del mismo género musical.

Dentro de todos los mecanismos de intervención colectiva y particular que generaron un aparato cultural de identificación, anclado a las prácticas de escucha de la música, es importante hacer énfasis en la vivencia salsera desde lo individual. Aunque esta tesis no descuida los procesos colectivos y remarca su vitalidad e importancia, se orienta hacia ese «cómo experiencial» ${ }^{22}$ en la escucha, que intenta ser explicado en la construcción narrativa personal de sus protagonistas. Aunque un movimiento musical puede conducir un proceso colectivo, no hay que descuidar la elaboración personal de cada experiencia estética, que centrada en el sujeto receptor, que habita un mundo sincrético, multicultural, en el que incluso las temporalidades se entrecruzan, funciona como aparato performativo del «yo». Como he señalado anteriormente, las interpelaciones son un proceso distinto en cada persona; un proceso siempre vigente de actualización del yo, dinámico, más aun cuando la postmodernidad nos ofrece en bandeja nuevos artefactos culturales al alcance de la mano y nuevas vecindades que pueden residir al otro lado del mundo. Artefactos y vecindades que se van apropiando y re-significando en cada oyente. Mark Slobin (1993, viii) subraya que:

\footnotetext{
${ }^{21}$ Se dice que el compositor portorriqueño Catalino “Tite” Curet Alonso (1926-2003), poseía en su haber alrededor de 2000 canciones. Sus letras fueron un referente para la canción salsera de corte social y sus creaciones contribuyeron a posicionar a artistas como Joe Quijano, La Lupe, Cheo Feliciano, Ismael Rivera, Héctor Lavoe, por mencionar una pequeña muestra. De hecho, todos los grandes salseros han interpretado sus temas, que recorren también otros géneros como el bolero y la balada.

22 «Cómo experiencial» es el término que utiliza Ramón Pelinski (2005) en su artículo «Corporeidad y experiencia musical» y que alude a la música no desde la conceptualización y el yo pienso sino desde la experiencia y el yo vivo.
} 
«Todos somos culturas musicales individuales, que utilizamos retazos de sonidos compilados en colchas culturales para ayudarnos a mantener el calor. Pero somos durmientes inquietos; de vez en cuando tiramos las mantas, cambiamos la ropa de cama, buscamos las pastillas para dormir, o incluso compramos una manta eléctrica [...]». ${ }^{23}$

La metáfora de «colcha cultural» explica con precisión la forma en que cada individuo se provee de artefactos para hacerse un lugar en el seno de las sociedades. Esta colcha cultural suministra la protección o el confort para posicionarse en los distintos escenarios donde las personas tienen que asumir roles en la lucha por construir un sentido. Las luchas de los sujetos en el intento de construir un sentido se convierten en un punto álgido de toda esta reflexión y se asumen dentro de la deconstrucción del ideal identitario de esencia y unidad. La deconstrucción da paso a la disposición de un sujeto postmoderno que arma y desarma subjetividades en el transcurso de su historia personal. ¿Cuál es el papel del sonido en tal deconstrucción, en tales batallas? La música -que interpela a un individuo- es un sistema absoluto de estesis; en el momento estésico las personas se aproximan o se convierten en el ideal que tienen de sí mismas y, en ese momento específico, el sonido coadyuva al equipamiento de escenarios de realidad paralelos o simultáneos en el continuum de la vida cotidiana. Concordamos así con que la construcción de sentido es a la vez una construcción de realidades y a través de la experiencia estética los escuchas logran configurarlas. Esto es lo que denominaré en este estudio «mundos de sentido».

Asimismo, el ideal identitario y los mundos de sentido son perfeccionados cuando se cuentan. El relato de quién se es: el yo narrado. Narración que no tiene límites, que siempre está abierta y se va ajustando a las necesidades de ubicación de las personas en el mundo; en cada escenario social donde las personas han desarrollado un papel y en los tiempos en los que han desempeñado ese rol. Todo se va ajustando en el encuentro de la subjetividad con la narración de sí mismo.

\footnotetext{
${ }^{23}$ «We are all individual music cultures, using patchworks of compiled sounds stitched into a cultural quilt to help keep us warm. But we are restless sleepers; from time to time we throw off the covers, change the linen, look for sleeping pills, or even buy an electric blanket [...]».
} 


\subsection{La construcción narrativa de la experiencia}

Cuando los individuos miran sus experiencias en retrospectiva y son exhortados a describirlas, se pone en marcha la compleja operatoria de la construcción narrativa; en la cual se rearma la vivencia y el escenario y se advierten varios nexos, subjetivos, socioculturales o simbólicos por ejemplo, que condicionan la experiencia. O sea, hay significados inscritos en el mismo momento y lugar en que se verifica. Pero, además, al contar los sucesos se brinda la posibilidad de que los significados construidos en o para la música se articulen en la narración. En el relato del bailador de la rumba, del programador o $\mathrm{Dj}$, del coleccionista viejaguardero o de quien solo escucha en casa, justamente, nos damos cuenta de que la teoría narrativa ayuda a solucionar la disyuntiva de la negociación de sentido, de tal forma que la narración se vuelve un ejercicio significante para su autor. Esto supera la idea de la narrativa como recurso literario y la convierte, en términos de Paul Ricoeur, en una herramienta para que las personas comprendan la realidad y den coherencia a su vida. Por lo tanto, cuando los melómanos describen sus prácticas con la salsa, su experiencia histórica con la música y las interacciones con los artefactos que se desprenden de ella, se pone de manifiesto la función de la narrativa en la tarea de dotar de sentido el relato personal; de cohesionar los hechos que conforman una vida; gracias a lo cual el relato redunda siempre en una construcción narrativa de la identidad (Ricoeur [1985a] 2004).

Desde el final del segundo capítulo, donde se aborda la generación de significados de valor social, y en el resto del presente documento, se explica la construcción de mundos de sentido en el salsero bogotano. Pero al afirmar que la estesis y los diferentes fenómenos de significado guían la construcción narrativa de la experiencia, estamos abordando otro mundo de sentido en la narración misma, puesto que ella organiza las acciones y organiza el tiempo; es decir, esclarece los modos en que el tiempo y la experiencia han transcurrido o transcurren. Ricoeur plantea que toda narrativa presenta una estructuración doble del tiempo: por un lado, se configura un tiempo del relato, de aquello que está siendo narrado, y por otro, se presenta un tiempo del discurso, el tiempo de la narración misma ([1985] 2008, 115), lo cual consolida dos vivencias 
diferentes, por lo que hay un mundo de sentido en la experiencia de la música y otro en su narración. ${ }^{24}$

Ricoeur expone que las identidades van elaborándose en el transcurso de la narrativa, y la clave para dotar de sentido el relato es la construcción de la trama que cada cual hace a través de sus vivencias particulares; en otras palabras, su trama argumental. A partir de aquí la identidad de un individuo es estructurada en el argumento de su historia. Él elige los hechos y las ficciones que le permiten ser lo más parecido a lo que necesitara o quisiera ser, y descarta aquello que no encaja correctamente en la descripción de su trama argumental. No obstante, la trama recoge también aquellos argumentos que le han sido impuestos para que sean parte de su relato, los cuales, normalmente ya han sido asumidos por las personas; construcciones que son muy usuales en las descripciones identitarias colectivas y de curso histórico. ${ }^{25}$

Otra consideración vital de su teoría es que la identidad se encuentra en una categoría práctica, puesto que al responder por el «quién», en cuanto a autor de una acción, se está contando la historia de una vida y así el relato señala el quién de la acción. «Por lo tanto, la propia identidad del quién no es más que una identidad narrativa» ([1985b] 2004, 997). Esta practicidad se resume en dos condiciones: Primera: al tiempo que la identidad narrativa responde a la pregunta del quién para determinar el agente de una acción, también contiene la acción en sí misma; esto es la acción contada o el relato de la acción.

Segunda: la constitución de la identidad narrativa articula dos estadios de existencia o realización; el relato histórico y el relato de ficción, la historia y la literatura (Ricoeur [1985b] 2009, 996-97). Por esta razón se concibe la relación entre acción y narración

\footnotetext{
${ }^{24}$ En términos de Ricoeur: «Me propongo excluirlos [los aspectos temporales] del acto de configuración textual y mostrar el papel mediador de este tiempo de la construcción de la trama entre los aspectos temporales prefigurados en el campo práctico y la refiguración de nuestra experiencia temporal por este tiempo construido. Seguimos, pues, el paso de un tiempo prefigurado a otro refigurado por la mediación de uno configurado» (Ricoeur [1985a] 2004, 115).

${ }^{25}$ La elaboración narrativa de la identidad en pueblos y naciones se ha producido en la historia, en términos que Néstor García Canclini describe así: «La identidad es una construcción que se relata. Se establecen acontecimientos fundadores, casi siempre referidos a la apropiación de un territorio por un pueblo o a la independencia lograda enfrentando a los extraños. Se van sumando las hazañas en que los habitantes defienden ese territorio, ordenan sus conflictos internos y fijan los modos legítimos de vivir en él para diferenciarse de los otros. Los libros escolares y los museos, los rituales cívicos y los discursos políticos, fueron durante mucho tiempo los dispositivos con que se formuló la Identidad (así, con mayúscula) de cada nación y se consagró su retórica narrativa» (García Canclini, Néstor 1995, 107).
} 
desde una mímesis ${ }^{26}$ creadora; es decir, si como apunta Vila «somos sujetos múltiples y fragmentarios en un cuerpo, son nuestras imaginarias construcciones narrativas las que mantienen nuestra precaria identidad personal» (Pelinski 2000, 171). Mediante esta relación de mímesis, la narración «rehace el mundo humano de la acción». Dicho proceso narrativo contempla un retorno en el cual se prefigura un antes y, posteriormente, una vuelta que refigura un después; pero ambos trayectos se disponen en el momento mismo del relato; de la narración de la historia de vida, que es el punto central en el cual se configura la construcción de la trama. ${ }^{27}$

En la experiencia musical de la escucha se evidencia la posibilidad de que los diversos significados que las personas asignan a la música se articulen con la narración de sus vivencias. También vemos que todo se conjuga en diferentes ejes temporales: la temporalidad actual que instaura la misma acción narrativa, el tiempo real en el cual suceden los hechos históricos que constituyen la vivencia y la temporalidad interior que la música convoca en cada sujeto. Esta última es un referente de un mundo interior personal que no está vinculado necesariamente al momento de una vida; perfectamente, cada individuo puede establecer tiempos remotos o futuros que se organizan psicológicamente para otorgarles sentido a sus posiciones identitarias.

\subsection{El cuerpo en las músicas populares urbanas}

La visión del cuerpo en las músicas populares generadas, asentadas, desarrolladas y vividas en la gran ciudad latinoamericana o en la ciudad del Caribe urbano, comporta implicaciones mayores que la musicología apenas empieza a tratar. De hecho, la experiencia y la corporeidad que en ellas se vivencia son un componente categórico en el intercambio cultural. El incesante flujo de músicas populares urbanas que permean y promueven una industria cultural a gran escala, que impactan sobre los medios de comunicación y que gestionan la formación de públicos y gustos para su consumo, por

\footnotetext{
${ }^{26}$ En el sentido de creación, la mímesis es un vocablo acuñado en la poética y la estética clásica que expresa una imitación de la naturaleza.

27 Según Ricoeur esta triple mímesis se describiría como: mimesis II la configuración, figura central puesto que es la invención, la construcción de la trama; mimesis I la prefiguración, es decir, el antes, y mimesis III la refiguración, esto es, el después. Entonces -mimesis II- la configuración textual, media entre -mimesis I- la prefiguración del campo práctico y -mimesis III-su refiguración. De esta forma la tercera relación mimética vuelve a la I a través de la II, dibujando un círculo hermenéutico a partir del campo práctico con el momento de la prefiguración y regresando al mismo campo práctico mediante la refiguración. Así, la segunda refiguración es la ejercida por las historias de vida.
} 
decirlo fácilmente, deben estar en la agenda de los estudios académicos. Simón Palominos y Juan Pablo González (2013, s.p.) advierten:

En efecto, el estudio de las músicas populares ha encontrado espacios de desarrollo académico desde fines de la década de 1970. No obstante, en América Latina la institucionalización de este tipo de investigaciones sólo alcanza madurez durante la última década del siglo XX (González, 2001). No exento de dificultades, y en concordancia con los estudios culturales, el campo de estudios de la música popular tiene dentro de sus principales interrogantes la definición misma de lo popular y la aplicación de esta noción a la música.

Ahora, el estudio de la «experiencia» en las músicas populares y, más aún, de la experiencia en la recepción, no ha tenido mucho lugar en el dominio de la musicología y de los estudios en músicas de raigambre urbana. Es crucial comprender ese «cómo experiencial» para explicar de qué forma la música que transcurre y se vive en la ciudad «constituye un espacio simbólico en el que múltiples agentes entran en relación y establecen intercambios culturales en la construcción de hegemonía dentro de nuestras sociedades» (Palominos Mandiola y González 2013). No obstante, como se ha venido elaborando hasta ahora en el presente texto, la música constituye espacios simbólicos pero también reales, y así como porfía en la construcción hegemónica que tiene un ascendente grupal, persevera más encima en la construcción inacabada del yo, del sujeto individual.

En el estudio de la experiencia de la recepción musical, DeNora apuesta por una comprensión de la música como artefacto cultural que «hace» más que «significa», y trae a colación el éxito de esta postura en autores como Middleton o Frith. Es una apreciación acertada que ha ayudado a desatar el nudo en que se encontraba enredado el rol de la música en la construcción de subjetividad y socialidad. Mas, aun con estos avances, es necesario apelar a lo discursivo mientras en el campo de estudio tengamos que recurrir a las definiciones que abarca la música en la vida cotidiana. Resulta que lo discursivo sigue siendo insuficiente para hablar del «hacer» y del «significar». Nuevamente, recaemos en el cómo explicarlo y el problema reitera que, por norma, nos remitimos a las definiciones en los códigos lingüísticos. Cuando estudiamos la música hemos visto que la referencia a tales códigos es insuficiente para entender todo lo que se establece en la interacción con un género. Entonces, observamos lo que «hace» la música, que tampoco puede ser descrito cabalmente en términos del lenguaje. 
La pregunta que surge es si necesariamente debemos explicar todo lo relacionado con el «hacer» y el «significar» de la música en términos de lo lingüístico; si lo podremos hacer algún día con un vocabulario disciplinar, específico del campo, que nos evite la eterna recurrencia a la metáfora. Por supuesto que algunos aspectos de la música sí son claramente adscribibles a lo lingüístico, pero el problema se plantea ante todo cuando debemos hablar de eso que la música «hace» en el cuerpo. Prácticamente, es una doble pregunta: por qué sería necesario hacerlo y si puede lograrse en una jerga musicológica.

En los últimos años la investigación en el campo apremia por el surgimiento de nuevas voces que suplan la urgencia de denotación y connotación de los fenómenos inscritos en las prácticas musicales desde la producción y la recepción. Evidentemente, deben ser vocablos -ya van surgiendo algunos- que se conformen en y para lo disciplinar, los cuales se empeñen en la estabilización de su significado. En esta etnografía surgieron cuestiones urgentes de solución lingüística. Por ejemplo, me era imperiosa la necesidad de dar un nombre a «eso» que ocurre cuando la voz emana del cuerpo, pero portando la corporeidad del intérprete; aquello que, en términos de Roland Barthes (1982, 265), arrastra al placer, y es precisamente de lo que no se habla, porque no se han producido los términos. También el trabajo de Paula Vilas (2005) retoma la noción desde el sentido de la producción corporal de voz, a través de su dimensión socio-históricocultural, y en este caso por medio del canto en grupo; no obstante, esta dimensión tiene mucho valor en cuanto otorga una gran importancia al sentido representacional de la voz. Sin embargo, dicha dimensión es representación pero, a la vez, materialización de aquello que se representa. Ambos aspectos son centrales en el acercamiento que propongo de la intervención de las voces salseras en la performatividad de los oyentes, por lo cual convine en apegarme a éstos dos autores y afirmar la noción de vocalidad como superadora de voz o timbre vocal. ${ }^{28}$

\footnotetext{
${ }^{28}$ Freya Jarman-Ivens en Queer Voices. Technologies, Vocalities, and the Musical Flaw, habla de la voz cantante, como un lugar estratégico para la aparición de espacios queer, en el cual pueden hacerse audibles diversas tecnologías relacionadas con el registro y producción de la música, las tecnologías internas (fisiológicas) de la propia voz o las tecnologías del poder en el sentido de Foucault (2011). Por su parte Nina Eidsheim trata el timbre vocal como un artefacto cultural que produce en el oyente asociaciones de raza y género. Discute la esencialidad del cuerpo y le atañe a la producción vocal las mediaciones que éste conlleva: «tanto el cuerpo como el timbre están conformados por prácticas inconscientes y conscientes que funcionan como repositorios de actitudes culturales hacia el género, la clase, la raza y la sexualidad» (2009). Por tanto, define el cuerpo y la voz como un artefacto que implica y transmite ideologías.
} 
Con respecto a lo lingüístico de la experiencia musical y de la etnografía en sí, también fue menester, tan interesante como dispendioso, encontrar definiciones, o mejor explicaciones, a vocablos que ya se han arraigado en el mundo de la escucha y el conocimiento salsero; que han sido significados a través de sus usos y a partir de las convenciones que se han ido estableciendo en el medio. Entre ellos: sabor, melodía, sonar, instrumentación. El vocablo sabor fue una remisión recurrente de mis informantes, que sugiere las circunstancias en las que el músico, el cantante o el bailarín acoplan la ejecución instrumental o el movimiento corporal a la definición de ritmo que tiene la salsa. Por lo tanto, entre las nuevas voces de la musicología y las voces que han surgido en el argot salsero aproximaré las articulaciones que se originan entre la interpretación del canto salsero, el oyente y la escucha, junto a las mediaciones que se inscriben en la corporeidad.

Resulta de gran interés y, a la vez, algo complicado, que dichos vocablos y definiciones confluyan y actúen en el mismo recipiente. Aquello que hace la música o los significados generados en la interrelación de los oyentes con los géneros populares urbanos atraviesa un tamiz estésico, un lugar de encuentro del sonido, la percepción y la emocionalidad: el cuerpo; acompañado de sus mecanismos de escucha y vivencia de la música que formulan diversos y complejos mundos de sentido en cada persona. En palabras de Pelinski:

La corporeidad desempeña un papel decisivo en la producción de significados musicales primordialmente vividos en la experiencia musical subjetiva de manera preconceptual y antepredicativa, a la vez que abierta al entorno social y natural e informada por él (2005, s.p.).

El texto de Pelinski Corporeidad y experiencia musical aborda desde una óptica fenomenológica las «relaciones recíprocas entre corporeidad y experiencia musical». Para este cometido aclara conceptualmente la diferencia entre los términos corporalidad y corporeidad y entre percepción y experiencia. Seguidamente, el autor invita a hacer una reflexión sobre los supuestos teóricos involucrados en la «experiencia musical subjetiva» con el ánimo de escudriñar en las conexiones de «la comunicación intersubjetiva y de las 'provisiones' del entorno natural». Concluye, entonces, que su análisis avanza en la siguiente dirección: desde una teoría de la corporeidad hacia su aplicación a la práctica musical, y desde la subjetividad silenciosa de la percepción musical hacia su trascendencia social y medioambiental (2005). Asimismo, entender 
que la corporeidad está constituida también por la vocalidad, despeja una ruta amplia para descifrar la performatividad del yo en la experiencia musical; asunto que trataré en el capítulo cuatro.

Desde este supuesto, vale esclarecer que las metáforas conceptuales, préstamos entre teorías, tentativas de definiciones, entre otros, han servido bien a la descripción etnográfica. Era primordial en este trabajo aproximarse a la experiencia y al cuerpo vivido en la música dentro de la ciudad. Así que acogerse a la explicación de la corporalidad y la corporeidad fue decisivo, porque en este aparte salen a relucir dos maneras de constituirse el cuerpo que son ambas significativas en las prácticas de la salsa: la biológica y la vivida. El cuerpo biológico es, naturalmente, la estructura física, la condición material que hace posible la corporalidad. Sobre el cuerpo vivido, es decir, el cuerpo en su condición de corporeidad, la noción de Pelinski, aclara lo siguiente:

Aunque todos los seres humanos poseen un cuerpo, no todos lo viven de la misma manera. En efecto, el cuerpo vivido es una estructura experiencial fenoménica, que funciona como nuestra consciencia subjetiva, sumergida en un mundo diferenciado por contextos históricos, socio-culturales y medioambientales. El cuerpo vivido es el sujeto de las acciones habituales que pueden realizarse independientemente de la intervención iluminadora y explicativa de la razón. El cuerpo vivido no se inscribe ni en el dominio físico-objetivo de la ciencia empírica, ni en el dominio puramente ideal de las representaciones mentales (Merleau-Ponty 1997: passim); no es ni material ni mental. Su modo de existencia es el de un objeto intencional, vivido fenoménicamente como percepción corporalizada que tiene preeminencia sobre la conceptualización abstracta: antes de ser pensamiento, idea o concepto, el cuerpo vivido es la experiencia de nuestras capacidades sensibles, perceptivas y, por lo tanto, preracionales (antepredicativas), y prelógicas. Lejos de ser una realidad puramente mental, mi cuerpo propio es consciencia intencional vivida a través del cuerpo físico, pensamiento corporalizado, encarnado, que no se inscribe en el círculo de mis representaciones intelectuales (Welton 1998: 184; Crossley 2001a: 101). [...] (2005). ${ }^{29}$

La racionalidad establecida en la visión cartesiana que determina el aforismo «pienso, luego existo» (cogito ergo sum) es construida bajo preceptos lingüísticos y conceptuales, lo que ha dejado a un lado la realidad de lo cotidiano en el mundo

\footnotetext{
${ }^{29}$ Los textos citados por Ramón Pelinski, son los siguientes: Welton, Donn. (ed.). Body and Flesh. A Philosophical Reader. Malden, MA: Blackwell. 1998 y Crossley, Nick. «The Phenomenological Habitus and its Construction». Theory and Society 30: 81-120. 2001
} 
perceptivo y sensible. Como consecuencia de este sujeto de la razón, de la ilustración, se ha instalado un abismo entre cuerpo y mente que apenas empieza a superarse. Maurice Merleau-Ponty observa que «La consciencia es originariamente no un «yo pienso que», sino un «yo puedo» ([1945] 1993, 154).

Cuando una persona ejecuta un movimiento corporal que se origina en el contacto con la música, fácilmente notamos que el cuerpo se ha incorporado en ese universo sonoro determinado. Con la salsa esta experiencia es indiscutiblemente patente, y la corporeidad se manifiesta en múltiples formas. Formas definidas a partir de la experiencia de escucha del género; pues van desde un movimiento rítmico menor de alguna parte del cuerpo, hasta el despliegue habitual del baile, lo que redime su ya existencia pre-conceptualmente. Este es un claro ejemplo de cómo los contenidos de esa experiencia se vinculan, de acuerdo a Merleau-Ponty, en una «unidad intersensorial de un mundo» sin situarse bajo la dominación de un «yo pienso». Pelinski complementa: «Esta perspectiva corporal sobre nuestra capacidad de comprensión y de acción, que, sin control directo de las representaciones racionales del pensamiento, acentúa la capacidad perceptivo-motora del cuerpo, es particularmente adecuada para una exploración de prácticas musicales tales como, por ejemplo, el aprendizaje y la ejecución instrumental» (2005, s.p.). A tales prácticas es preciso agregar, no con menor importancia, la experiencia estética del sujeto de la escucha, gracias a la cual configura una subjetividad en el instante en que transcurre la música, física o mentalmente. Experiencia que además se conforma de un antes y un después cuando está afectada por condiciones ambientales o socioculturales que la anteceden o la preceden en estrecha relación.

Pelinski ilustra en un estudio sobre los Inuit del noroeste canadiense, la forma en que Tautungi, mujer de la comunidad, se incorpora en su identidad a través de un ritual que contempla su canto personal y su danza, en el cual éstos, antes que ser representativos constituyen efectivamente su alma y su nombre. Aquí, de acuerdo con el autor, la vivencia del ritual identitario no remite a otros signos, por lo tanto no es simbólica, sino que es experiencia efectiva. Las músicas populares urbanas, en una localización muy diferente y casi contrastante, ante todo cuando la aplicación del concepto «comunidad» no es viable, inevitablemente tienen un contexto enriquecido de escucha, lo que no niega que la experiencia de la performance en intérpretes o receptores no sea efectiva. La experiencia estética del sujeto de la escucha anuncia la transformación del yo en la 
música, y es una transformación real; por consiguiente, aquel ‘yo’ encarna a 'otro’ en la experiencia, como veremos más adelante.

\subsection{Salsa y performatividad}

La idea de experiencia efectiva sobre la realización de la identidad estudiada por Pelinski es respaldada hasta cierta parte por Rubén López-Cano. No obstante, al estudiar la performance identitaria infiere que la experiencia de la música se constituye también en el afuera de la percepción sensorial, en todo aquello que la integra desde lo simbólico (López Cano 2013b). Dirigiéndose, asimismo, al problema de la discursividad y el cómo cada constitución del hacer acarrea una disposición simbólica que ayuda a constituir la experiencia, indica:

Si bien la experiencia corporal puede llegar a traducirse en esquemas cognitivos como los esquemas encarnados a partir de los cuales podrían integrarse a otros discursos o narrativas, ésta posee también aspectos que no se pueden asimilar a discursos, narrativas o esquemas: yacen en el cuerpo y sólo son recuperables a través de él. Sin embargo, entre ambas existen vínculos y relaciones no a niveles de representación sino de articulación múltiple que se reflejan en disposiciones, invitaciones, instrucciones y posibilidades efectivas de acción. ¿Qué papel cumplen en estos dispositivos los procesos simbólicos o las construcciones simbólicas? (2013a, 51).

La incorporación del «otro» en el «yo» deseado por medio del baile salsero es solo una de las cosas que inspira el género -es más que «bailar»-; su constitución simbólica es evidente y está unida, entre otros, por los siguientes indicadores:

I Tradición del baile: la forma de bailar, el despliegue del cuerpo en la danza que interviene directamente en la performance de los oyentes.

II Estabilización del significado en sus públicos: la salsa es «categóricamente alegre», es y representa el goce, la libertad y la alegría.

III Ritualización de la felicidad: lo adverso se desconfigura en el baile y se orienta el ideal del bienestar y de la felicidad.

Al situarnos únicamente en el baile los tres elementos simbólicos operan en la performance del oyente; cosa que se advierte en la observación directa de la rumba y se manifiesta en la descripción posterior que hacen los bailadores sobre la vivencia. Pero 
en el baile mismo la performatividad instaura el otro yo. No hay elementos de fingimiento en la resultante corporal, que sí pueden estar presentes en el relato identitario. El cuerpo y el entorno se desconfiguran y refiguran instalando nuevas realidades, lo que no indica que la experiencia del oyente no esté sedimentada por un cohesionador sígnico. López Cano dice: «El objetivo es modelar un proceso simbólico y, por lo tanto, sustentado en signos, en donde lo "representado" no significa, sino que es» (2013a, 46).

Adentrados en el terreno de la performance es preciso definir la diferencia entre performativo y performático. John Austin (1962) explica la performatividad del lenguaje como la acción inminente suscrita al momento de la enunciación, y así la acción discursiva es el fundamento de la performatividad. A los estudios de Austin se suman los de Philip Auslander (2006) que asumen el proceso performativo como totalizador de la experiencia de la escucha musical, puesto que la articulan con el contexto que experimenta cada individuo oyente; es decir, tanto el músico como el público se consideran seres sociales cuyo ejercicio tiene lugar en un contexto social del cual no pueden abstraerse. Entonces, lo que atañe al «dominio tradicional de la performance, a sus elementos teatrales» que redundan en la interpretación, ha convenido en llamarse performático; y lo referido al discurso y a la enunciación, «performativo». ${ }^{30}$ En este orden de ideas podemos ver la música como un texto; con lo cual se diría que adquiere las propiedades de un discurso; ya que posee la condición de enunciarse y de causar performatividad en los sujetos que la producen y la escuchan.

Estas razones nos indican que los procesos performativos no son aislados ni se supeditan exclusivamente a los elementos del sonido en el momento de la escucha. Desde una interpretación de la semiótica de Charles Peirce dirigida a la experiencia musical, López-Cano (2013a) infiere que los significados de la música se vehiculan dentro de la red de interpretantes en un proceso indefinido de semiosis. Si bien lo anterior nos dirige a la disciplina semiótica, es necesario aclarar que los postulados de

\footnotetext{
${ }^{30}$ En la introducción al dossier sobre estudios de performance de la revista TRANS número 13, Alejandro L. Madrid advierte sobre el problema que supuso encarnar tal discusión. Ante todo por la visión ortodoxa aún persistente del abordaje de la performance en la interpretación, composición y posiblemente la improvisación. Asunto que deja a un lado los fenómenos performativos que afectan a «la construcción de identidades, el uso enunciativo del lenguaje, el activismo político o el uso del cuerpo en la vida cotidiana». En el mismo texto, Madrid señala que en el Congreso de la Sociedad de Etnomusicología, SIBE, llevado a cabo en 2008, se consensuaron dos usos derivados del término performance: «performativo» como adjetivo o cualidad del discurso y «performático» como los estudios tradicionales referidos a sus elementos teatrales (2009, s.p.).
} 
Peirce, lejos de adherirse a la semiótica estructuralista, conversan con otras reflexiones que, en palabras de López-Cano, hacen más operativo el tratamiento de los fenómenos musicales, y con mayor razón los que atañen a la relación con el cuerpo. En este sentido, su propuesta desafía una exégesis semiótica de la representación para adentrarse en una semiótica performativa. En el estudio de la salsa, tal aproximación ofrece un dispositivo conceptual muy oportuno, debido al abordaje que se hace de la experiencia en términos de la corporeidad de los oyentes, el cual trasvasa los límites del disfrute con el género musical para constituir identidades y realidades en, antes y después de la escucha.

Por consiguiente, en el estudio de la experiencia estética del melómano salsero bogotano fue crucial observar la operatoria de la performatividad. El momento en que se acciona el mecanismo performativo es constitutivo de la experiencia estética. Este mecanismo pone en situación al oyente, otorgándole la posibilidad de asumir distintas identidades y de intervenir en la realidad. Cuando el melómano entra en contacto con la salsa, cuerpo, mente y entorno constituyen, en palabras de López-Cano, un continuo indivisible que dispone al individuo en una nueva forma de estar en el espacio-tiempo.

Así pues, es necesario definir concisamente las nociones de signo e interpretante y fijar su lugar en los procesos de semiosis. Entender las interpelaciones y articulaciones que se generan en la música en concomitancia con los criterios de una semiótica performativa es crucial en el propósito de comprender la función de la música en la cotidianidad de sus escuchas. Desde la visión peirciana, según López-Cano, entenderemos, por tanto, el concepto de signo con relación a «cualquier percepción, pensamiento o estado que permita comprender algo distinto a sí mismo, es decir, que reenvíe a otra cosa» (2013a, 44). Pero para que un signo remita a algo diferente de sí mismo es necesario que otro signo lo interprete. De aquí surge el concepto de interpretante que el autor, citando a Humberto Eco, conviene en que:

[...] puede ser un signo equivalente en otro sistema sígnico, un índice que apunta sobre un objeto particular señalando toda la clase de objetos a la que éste pertenece, una asociación emotiva, una definición científica de carácter técnico o de mero sentido común o la simple traducción del término a otra lengua (2013b, 52).

De esta forma, cada signo estaría inmerso en un ciclo de traducciones a otros signos consolidando una red de interpretantes; pues cada interpretante sería interpretado por 
otro y así sucesivamente hasta que, en suma, repercutan en el significado de algo. Mas hay que advertir que este ciclo no es un mero compendio de funciones sino una articulación significativa y resolutiva entre cada interpretante, constituyéndose bajo dicho mecanismo la semiosis. Cuando el signo agota su re-direccionamiento a otros signos, cuando queda coartada la posibilidad de más interpretaciones, nos encontramos con un código. El código es fundado en una convención cultural; prácticamente una norma que ha llegado a convertirse en tal a partir de lo que Peirce denominó un hábito interpretativo. Esto es una manera común de pensar sobre ciertas cosas que se ha afincado en el seno de las sociedades a fuerza de la reiteración de su uso, y por lo tanto ha estabilizado determinadas significaciones.

La teoría semiótica nos ayuda a comprender el proceso de articulaciones -y desarticulaciones- que se verifican en la experiencia estética de la música, puesto que el repertorio de signos interpretantes es tan amplio, que deviene, en palabras de LópezCano, en «estados afectivos, movimientos corporales y procesos lógicos reales y efectivos». Los procesos musicales afincados en la escucha están subsumidos en esas categorías de tal forma que se articulan en unas redes vinculantes de complejas implicaciones. En este estudio la performance constituye en sí un proceso semiótico, que es dinámico y vital; que está inmerso en una red vinculante que lo dota de sentido, al igual que otras interacciones humanas en torno a la música que se constituyen independientemente de la experiencia performativa. Entonces, la semiosis nos muestra cómo está dotado y cómo funciona el andamiaje sígnico de interpretantes, al cual se circunscriben distintas experiencias. Y aquí hay que recordar el objetivo de la semiótica performativa propuesta por López-Cano «en donde lo "representado” no significa, sino que es», a lo que agrega que no solo se trata de entender la semiosis como un proceso donde los signos significan encontrando eco en una producción discursiva, signos reenviando a otros signos, sino que también «hacen cosas».

Por otra parte, pensar la performatividad del «yo» tiene eco en las teorías postmodernas sobre la identidad. El sujeto de la postmodernidad, descentrado, sin núcleo fijo, descrito por Hall, es un sujeto en permanente construcción; facultado para producir múltiples subjetividades. Aunque la tentativa de Foucault es eliminar al sujeto, o sea, eliminar las sujeciones ya que se originan en un ejercicio de control y de poder sobre el otro, el individuo postmoderno insiste en sujetarse a algo. La sujeción a la música es obstinada y, como se verá en las interpelaciones y articulaciones de la salsa, hay un ejercicio de 
dominación pero a la vez de liberación de subjetividades, por más contradictorio que pueda parecer. En esta sujeción el precepto experiencial y la corporeidad juegan un papel sustantivo, puesto que el eje catalizador de la experiencia es el cuerpo, dotado de su corporalidad y de su corporeidad, la cual también es portadora de registros de lo que sucede en el seno de la vida social. En la vivencia de la salsa el cuerpo tiene implicaciones capitales, más aún cuando es un género musical, por excelencia, bailable. En consecuencia, a partir de las teorías y las interpretaciones mencionadas, el intento es demostrar que para los escuchas salseros la experiencia estética o la estesis en el sonido, junto a distintos fenómenos de significado que se cimentan en las interacciones sociales en el ámbito salsero bogotano, son vitales en la realización de sus mundos de sentido. 


\section{CAPÍTULO II. APROPIACIÓN DE LA SALSA EN COLOMBIA}

En el presente capítulo se exponen brevemente las condiciones históricas, políticas y culturales que favorecieron al asentamiento de la salsa en Colombia y su especial arraigo en Bogotá; lugar donde se promovieron prácticas profundamente significantes en torno a su escucha. Comprende cinco secciones que conectan el proyecto musical nacionalista basado en las músicas tradicionales, las huellas o marcas características del barrio latinoamericano moderno impresas en el sonido de las músicas populares urbanas del siglo XX, las formas en que la salsa se apropió en diversas ciudades del país, la evolución cronológica en la escucha de la salsa y las músicas caribeñas y el establecimiento de la vieja guardia en Bogotá. Con respecto a este último es necesario diferenciar dos géneros salseros; el clásico y el romántico, porque demarcan estructuras musicales diferentes y a la vez otros públicos y otros contextos.

Es importante hacer hincapié en la familiaridad que ya había antes de la década del sesenta con las sonoridades caribeñas, pues el surgimiento de la radio en el país en los años treinta propició, en cierta medida, la circulación de géneros musicales cubanos. Así, en la audiencia empezaron a tener eco boleros, sones, guarachas o rumbas; aires que se consolidaron en el ambiente musical apoyados, además, en el comercio marítimo que permitía el intercambio de discos de acetato. Con esto se evidencia que las costas colombianas no fueron ajenas al tránsito musical de la Cuenca del Caribe; músicos y músicas han circulado procurando transferencias interculturales que han hibridado el panorama sonoro de la región. Se muestra, entonces, cómo progresivamente los aires costeños, marcadamente afro, penetraron en el interior del país bajo un singular proceso de transformación; ya que aquellas ciudades adeptas a las músicas andinas veían con recelo la intromisión de músicas preeminentemente «negras». No obstante, era un proceso urgente con vista a re-formular una noción de identidad nacional orientada en la felicidad que inspiran tales músicas, lejos de los sinsabores de la violencia que venía recorriendo la historia de la nación. Bajo estos antecedentes y la incontestable vivacidad que caracteriza los ritmos salseros, el género no encontró resistencia alguna para entrar y esparcirse en el territorio urbano.

De hecho, los salseros proclaman axiomáticamente la salsa como el género de la alegría. Un factor que medió en la estabilización de semejante significado fue la sedimentación 
histórico-cultural que empezó a originarse debido a que en la segunda mitad del siglo $\mathrm{XX}$ empezaron a promoverse las cumbias, porros y gaitas provenientes del Caribe colombiano. Se consolidó entonces un sistema de difusión que alcanzó una cobertura masiva gracias a los medios de comunicación del territorio. Las músicas del Caribe colombiano también son llamadas tropicales o costeñas y su carácter es marcadamente bullicioso y festivo. Sin embargo, en principio, habían sido relegadas a planos secundarios o simplemente olvidadas dentro del país. Para empezar, por haberse producido en la periferia del territorio; luego, por tener una fuerte raigambre negra, ya que las zonas costeras donde se producen están habitadas en su mayor parte por poblaciones afrodescendientes; y por último, porque las representaciones de la identidad musical nacional estaban centradas en el bambuco andino.

En efecto, desde finales del siglo XIX los intentos por representar la identidad musical nacional habían comenzado a recaer en el bambuco, cuya representatividad era decidida desde la capital del país. El proyecto musical tuvo diversas inconsistencias y de altibajo en altibajo solo logró que el bambuco y sus variantes se consagraran como algunos de los aires representativos de la tradición local. Mientras tanto, las músicas costeñas empezaron a tener más eco en el interior y paulatinamente fueron adquiriendo importancia y protagonismo. Por su parte, la transnacionalización de artefactos culturales ha permitido que se vehiculen géneros musicales por encima de cualquier barrera geográfica, política o temporal. La agilidad de tales fenómenos, característica de la postmodernidad, ha permitido el desdibujamiento de las fronteras territoriales, dando paso a vecindades culturales antaño demasiado lejanas e impensables. Por lo tanto, esta sección dará cuenta de algunas formas en que los nuevos artefactos, además de facilitar el encuentro intercultural, se han asimilado, re-significado y reproducido en los lugares de acogida.

A manera de resonancia con lo que sucedía en la metrópoli neoyorquina que la produjo, la salsa fue vivenciada como si fuera propia en las calles citadinas de Colombia y se crearon sitios específicos para su disfrute. Los jóvenes sintieron una gran conexión con el nuevo estilo que fusionaba con el son proveniente de Cuba, géneros estadounidenses como el jazz urbano o el pop. Aunque el son fuera su fundamento, el híbrido neoyorquino le aportó potencia, riqueza armónica, textura tímbrica, voces y letras que lograron conectar fuertemente a los públicos. Igualmente, Nueva York imprimió en el género toda la vivencia de una población migrante que padecía los problemas de las 
minorías relegadas a guetos marginales donde la pobreza, la violencia y lo que de ello se desprendía eran sustento de lo cotidiano. Para los años ochenta la salsa tenía una fuerte carga de representatividad. El Barrio neoyorquino, ${ }^{31}$ morada por excelencia de los inmigrantes latinos, fue el protagonista del género, por lo cual había abonado un capital simbólico que permitió que los oyentes se identificaran con la salsa de múltiples formas. En la Bogotá de los ochenta particularmente estudiantes, académicos, artistas y gente de izquierda, encontraron en la salsa un lugar de goce pero a la vez de reflexión, de conocimiento, de crítica y de insurrección.

\subsection{Antecedentes de la apropiación de la salsa en Colombia}

Después de los procesos independentistas que enmarcaron el siglo XIX latinoamericano y las nuevas organizaciones territoriales, emergía el afán de consolidar un aparato de identificación nacional que a través de íconos culturales consolidara la unidad de los pueblos y proveyera a sus habitantes de característicos artefactos de identificación. El proyecto musical nacionalista no podía consolidarse sobre la base de expresiones amerindias o afrodescendientes; más todavía cuando estas últimas significaban aquello otro que no condecía con el anhelo de una sociedad lo más europeizada posible y, contrariamente, resaltaba las características de una población de color negro, de carácter supuestamente acrítico, notoriamente feliz y abiertamente bulliciosa, en la cual el cuerpo sobrevalorado traspasaba los límites de la moralidad. ${ }^{32}$ Esta absoluta contraposición con el pretendido «ser andino» se advierte heredera de la concepción sobre los africanos que elaboraron los europeos y compartieron con el resto del mundo. Peter Wade la describe en los siguientes términos:

\footnotetext{
${ }^{31}$ Cuando se habla de la salsa neoyorquina ha de entenderse que El Barrio es un conjunto de zonas urbanas de Nueva York denominado el Spanish Harlem. A él llegaron los primeros inmigrantes puertorriqueños desde la década del veinte. Alejandro Ulloa (2009, 81) cita a Clara Rodríguez para expresar que el primer foco de migración latina, generado entre 1900 y 1945, se asentó en Brooklyn, el East Harlem (El Barrio) y el South Bronx.

32 Sobre la historia de las músicas negras en las dos costas colombianas Egberto Bermúdez hace un recorrido exhaustivo sobre la documentación elaborada desde, aproximadamente, el siglo XVI por diversos cronistas e historiadores. Aunque el corte de los textos encontrados sea preponderantemente descriptivo, no deja de revelar el continuo hostigamiento hacia las expresiones negras: «La costa Atlántica, como puerta de entrada al país, tuvo mayor cobertura en lo referente a descripciones de bailes e instrumentos. En 1735, Antonio de Ulloa y Jorge Juan y Santacilla proporcionan breves noticias sobre el fandango en Cartagena, baile propio del populacho de origen africano e indígena, bailes que entre 1769 y 1770 son censurados por las autoridades peninsulares y defendidos por las de Cartagena [...]» (2005a, 217).
} 
Desde hace varios siglos, y aun desde los siglos XIX y XX, los europeos percibieron a los africanos como gente de mucha sexualidad y mucha inclinación hacia la música y el baile, y esta imagen tuvo continuidad en las colonias americanas donde las autoridades consideraron que eran válvulas de escape para los sentimientos de los esclavos y también, que constituían una posible amenaza para el orden político y moral (2002, 29). ${ }^{33}$

En consecuencia, le era pertinente al primer proyecto musical nacionalista, invisibilizar $^{34}$ la presencia negra dentro del marco cultural que debía establecer el ideal identitario de la nación. Presencia que lógicamente formaba parte de la heterogénea topografía cultural, en términos de Wade, del territorio colombiano, pero que se desmarcaba del prontuario culto, melancólico y blanco perfilado en la región andina. El bambuco servía cómodamente a esa representación. Como lo explica Hernández Salgar, las músicas populares fueron parámetro importante en los marcos representativos de las identidades nacionales y han sido utilizadas en la urgencia de establecer dichos discursos; lo que explica que en la primera mitad del siglo hubiera una fuerte tendencia a posicionar el bambuco como uno de los aires nacionales más representativos:

\footnotetext{
${ }^{33}$ La obra del antropólogo británico Peter Wade centrada en la raza, la sexualidad y la etnicidad en América Latina enriquece considerablemente el panorama interpretativo del mestizaje a lo largo del siglo XX en el continente. Música Raza y Nación. Música tropical en Colombia (2002), plasma con detalle el asunto del estatus, o mejor no-estatus de las comunidades negras en el país, y las complejidades políticas y sociales que acusa el hecho de que se reconozca la histórica composición mestiza -'blanca', 'negra' e indígena- de la población colombiana pero se impida sistemáticamente su participación como agente de identidad de la nación; al menos hasta la década del ochenta. ¿Por qué esta fecha?: porque en 1991 se elabora una nueva constitución. La Carta Magna del 91 propende por la valorización de las diferencias y reconoce oficialmente la heterogeneidad racial y cultural. Entonces, comienzan a potenciarse los discursos «multiculturalistas» desde la institucionalidad. Hay que resaltar que los estudiosos del tema describen los procesos discriminatorios hacia lo negro y lo indígena como procesos de «invisibilización» en el marco post-independentista del proyecto identitario de nación. En cuanto al libro mencionado, la investigación de Wade muestra cómo la música de la Costa Atlántica, cuyo origen se asocia principalmente a un ascendiente negro o afro, empieza a convierte en la música de Colombia a partir de los años cuarenta-cincuenta. Dicha investigación analiza en profundidad las ambivalencias de la integración de «lo negro» a un aparato de identidad que se anhelaba instalado en «lo blanco». Parte considerable eran las músicas, y éstas fueron el sustento de un vuelco identitario desde los sinsabores de la violencia hasta la connotada alegría de la gente colombiana. La música desempeñó un papel político fundamental en la identidad de la nación, puesto que, justamente, las músicas adoptadas para la «nueva» identidad del país eran las músicas costeñas, negras, con su incontestable alegría.

${ }^{34}$ La invisibilización de lo negro fue sistemática y el término ha sido ampliamente utilizado cuando se acude al hecho. Un ejemplo verídico de tal actitud es presentado por Egberto Bermúdez al plasmar los intentos de notación musical de aires tradicionales del país, dentro de los cuales se hacía caso omiso a los ritmos costeros: «En forma significativa, Daniel Zamudio (1885-1952) no incluye transcripciones de música afrocolombiana en su trabajo sobre la música tradicional del país, originalmente presentado como conferencia en 1936 y no publicado hasta 1949. Probablemente, sus razones fueron de doble índole: por un lado, su abierta postura racista y poca simpatía por el tema y, por el otro, la dificultad que planteaban dichas transcripciones, comparadas con aquellas de música del interior del país y los ejemplos de música indígena que incluye en su trabajo» (Bermúdez 2005a, 219).
} 
Durante las primeras décadas del siglo XX la música andina urbana producida por una élite bohemia y letrada, usaba materiales sonoros que simulaban la dinámica emocional de la melancolía, produciendo una articulación con los valores predominantes en la sociedad bogotana de la época: el fervor católico, el culto a las letras, el amor por la herencia hispánica y la pretensión de ser una sociedad culta y blanca, a imitación de la Europa del siglo XIX (2014, 233).

Por consiguiente, se originaron dos asociaciones que integraron la escucha con la emocionalidad: en primer lugar, la moderación, la sobriedad y la melancolía se asociaron al bambuco andino que se cultivaba justamente en el interior del país. En segundo, la alegría y el dinamismo, a las músicas del Caribe colombiano. ${ }^{35}$ Normalmente las ciudades del interior de Colombia, dada la geografía de los lugares, son montañosas y de climas fríos. Excepto Cali, que goza de temperaturas muy cálidas todo el año, el resto de ciudades importantes del interior tienen la fama de ser «frías». En el sistema montañoso de los Andes, además, se localizan ciudades muy desarrolladas en el orden económico, comercial, industrial y poblacional. Al parecer, no solo la condición climática sino la localización geo-política ha alimentado el mito del carácter «frío»y «sobrio» de sus habitantes en contraste con las ciudades más periféricas, de desarrollo más lento y cuyos habitantes son más abiertos y festivos.

Sin embargo, era menester hacer un giro identitario. Darío Blanco Arboleda (2009) sostiene que después de las Guerras Civiles y de la época de La Violencia que asolaron la nación a lo largo de los siglos XIX y XX, ${ }^{36}$ el país decidió volcarse hacia la música tropical. En 1946 el partido conservador llegó al poder luego de un amplio periodo de dominación de los liberales. Empezó, entonces, una ola bárbara de hostigamiento y represalias en las zonas rurales. La situación empeoró cuando fue asesinado en 1948 el líder liberal Jorge Eliécer Gaitán, antes de los siguientes comicios electorales. Se desató a partir de ahí un intenso episodio de violencia y represión en Bogotá que se ha denominado El Bogotazo. El hecho repercutió en otras ciudades del país e instauró el nefasto periodo de guerra partidista ${ }^{37}$ denominado históricamente como La Violencia.

\footnotetext{
35 Óscar Hernández Salgar (2014) muestra el proceso en el que se consolida el mito de la melancolía andina y el de la alegría costeña en la música Colombiana. Ver su tesis doctoral titulada: Los Mitos de la Música Nacional. Poder y emoción en las músicas populares colombianas 1930-1960.

${ }^{36} \mathrm{Mi}$ intención no es establecer que las prácticas de la violencia se hayan extinguido en Colombia, ya que resurgen periódicamente en diversos lugares, o en los mismos, con diferentes facetas y nombres.

${ }^{37}$ Para la época los dos partidos que detentaban el poder y a causa de los cuales la guerra se intensificó en dimensiones alarmantes, eran el Partido Liberal, en teoría más tendiente a la apertura y a la izquierda, y el Partido Conservador, más tradicionalista y de tendencia derechista.
} 
Se extendió hasta la década del cincuenta y, teóricamente, culminó en 1958 con el acuerdo bipartidista denominado Frente Nacional. Pero aún con el histórico acuerdo se testimonia que los actos funestos persistieron aun en los años sesenta. En ese momento rezagos de grupos insurgentes liberales izquierdistas empezaron a organizarse para fundar las nuevas guerrillas de las cuales, a día de hoy, aún perviven algunas. La Violencia ocasionó que miles de campesinos migraran a la gran ciudad en busca de amparo y refugio, por lo que los centros urbanos se expandieron y se agudizó el conflicto socioeconómico de la periferia de las ciudades.

Con lo antedicho, el giro identitario hacia las músicas caribeñas puede estar sustentado en que las áreas costeras se identificaban menos con la situación de violencia y porque los focos de la guerra se propagaban más en el interior del país. Con respecto a La Violencia, Wade señala lo siguiente:

\footnotetext{
En términos comparativos, la región costeña se presentaba como bastante pacífica y esto contribuyó a reforzar otra lectura posible de la región, la de un lugar donde todavía reinaban valores comunitarios tradicionales. Teniendo en cuenta que mis fuentes casi nunca mencionaban "La Violencia", que afectó al sector rural más que a las grandes ciudades, es muy difícil precisar el papel de ideas como paz y violencia en las relaciones sociales. Podría ocurrir que los citadinos estuvieran predispuestos hacia una música "alegre" mientras que a su país lo desgarraba una virtual guerra civil; lo cierto es que "La Violencia" tenía ciertas expresiones literarias pero es bien difícil detectar su impacto en la música popular y por su lado la música costeña, con su contenido de celebración, ciertamente desconoce este fenómeno (2002, 180-81).
}

A lo anterior se suma que el giro identitario se vio favorecido porque durante las décadas del treinta y del cuarenta el bambuco y otros géneros andinos atravesaban una crisis que los ponía en total desventaja con las músicas extranjeras que promovía la radio (Santamaría-Delgado 2014, 119). Entre ellas, destacaban en la programación radial los tangos argentinos, los corridos mexicanos, las rumbas y guarachas cubanas y los foxtrot norteamericanos. Así pues, la familiaridad con dichos ritmos favoreció que los músicos colombianos se apropiaran también de ese repertorio y lo hicieran familiar en los entornos locales: «grabaciones de Jorge Áñez, en 1920, incluían un bolero cubano, un aire colombiano, y una ranchera mexicana; Alcides Briceño grabó foxtrot, marchas, tangos y habaneras cubanas; Alejandro Wills interpretó un aire utilizando un serrucho de carpintero como instrumento en Nueva York» (Wade 2002, 68). 
Las investigaciones de Wade y Santamaría-Delgado muestran asimismo que hubo ciertas vicisitudes en la comercialización de estos géneros a través de los medios; lo que se constata en una línea intermitente y poco definida de aparición o desaparición de algunos ritmos en periodos determinados. Wade $(2002,99)$ aclara que:

Por razones que todavía no están claras estas listas de discos desaparecieron de las páginas de La Prensa en el período 1934-1940, para reaparecer esporádicamente en 1941 y 1946. La lectura de los datos no arroja gran cosa, teniendo en cuenta que el tamaño de la muestra es bastante pequeño, pero aun así se evidencia el gran predominio de la música cubana (bolero, guaracha, conga, rumba, además de son y danzón), en tanto que las canciones mexicanas y los tangos, junto con el foxtrot norteamericano, constituyen una presencia minoritaria. A estas alturas han desaparecido los valses y otros estilos de música "europea" pero, en cambio, aparecen un par de porros grabados con la Víctor por músicos colombianos.

Se puede constatar que la música cubana ya tenía un referente en Colombia, notorio sobre todo después de los años treinta. En las colecciones privadas de melómanos colombianos reposan algunos discos heredados de sus antecesores con sellos como Modiner, Areíto o Panart, ${ }^{38}$ por lo que la presencia de agrupaciones del corte de El sexteto habanero, el Trío Matamoros o La sonora matancera, era habitual en la audiencia musical del país. La incursión caribeña facilitó la difusión de las músicas tropicales a gran escala en los medios; no solo en Bogotá, sino también en otras ciudades del interior.

Hacia los años cuarenta las músicas tropicales de la costa caribe colombiana habían empezado a invadir el interior del territorio colombiano; proceso que se apuntaló además en el dilatado mito de la alegría costeña y la melancolía andina, el cual determinaba el carácter andino en concordancia con el clima de las regiones, como frío, triste, reflexivo y autocontenido, mientras que el carácter costeño era, precisamente, todo lo contrario, como ya se ha señalado.

Así, por ejemplo, en términos tanto climáticos como sexuales, la región Caribe es percibida como "caliente" y la región Andina como "fría"; ésta ha sido, y es, más piadosa y católica, mientras que en aquélla el control moral eclesiástico ha sido menos fuerte y las pautas matrimoniales menos "ortodoxas". Sin embargo, a través del tiempo

\footnotetext{
${ }^{38}$ Estos sellos eran cubanos y convivieron con los internacionales RCA Víctor y Columbia, o sus respectivas filiales, que también optaron por registrar y comercializar músicas tradicionales de cada país.
} 
se observa que el resto del país se ha "calentado" y que en este proceso el Caribe colombiano ha desempeñado un papel crucial, en gran parte debido a su música.

Inicialmente, la música y la danza del Caribe colombiano fueron percibidas en el interior como ligadas a la negritud y, en consecuencia, como moralmente sospechosas y sexualmente explícitas, pero también, como excitantes, vitales, liberadoras (Wade 2002, 27).

El compositor Lucho Bermúdez (1912-1994) fue uno de los mayores promotores de los ritmos tropicales en el país y en el exterior, sobre todo desde la década del cuarenta. Bermúdez fue una de las principales figuras de origen costeño en abrirse paso entre los altos círculos sociales de la capital. Su labor como intérprete, arreglista, compositor y director y la manera en que modernizó la música de la costa, aportaron no solo en su difusión en toda Colombia sino en su reconocimiento en el ámbito internacional. Su agrupación, con un formato instrumental que tendía más al estilo de las Bigbands estadounidenses, llegó a tener 22 músicos, y el compositor recorrió el continente grabando en diversos lugares e, incluso viviendo temporadas en países como Cuba o México. Sobre su aparición en la escena de las músicas nacionales, el musicólogo Egberto Bermúdez comenta:

La música popular tuvo las mismas limitaciones [prejuicios locales sobre la visión internacionalista de la música] y aquella «música nacional» consolidada en las dos últimas décadas del siglo anterior basada en el bambuco, el pasillo y la danza, mantuvo su vigencia -enriquecida y modificada- sólo hasta los años 40. En ese momento -de grandes cambios sociales y económicos y bajo presión de las compañías fonográficas internacionales- se comenzó a reemplazar por otro paradigma, el de la música «caliente» o bailable, encarnado por Luis Eduardo «Lucho» Bermúdez (1912-1994) y modelado en tendencias internacionales y caribeñas, pero todavía basado en las tradiciones musicales campesinas costeñas $(2010,251)$.

A propósito de las apreciaciones sobre la música tropical con respecto a su candor y alegría, en el siguiente apartado se muestran algunos fragmentos de letras de canciones del compositor costeño: ${ }^{39}$

\footnotetext{
${ }^{39}$ Sin embargo, la alegría, inocencia, banalidad de las músicas tropicales obliga a emprender una revisión más profunda en el campo de las músicas tradicionales caribeñas, puesto que no es una característica
} 
$\underline{\text { Prende la vela - Mapale }}^{40}$

Negrito ven prende la vela,

negrito ven prende la vela,

que va a empezar la cumbia en Marbella,

que va a empezar la cumbia en Marbella.

Prende la vela que la cumbiamba pide candela.

Prende la vela que la cumbiamba pide candela.

\section{Salsipuedes - Porro}

Hoy quiero gozar, quiero vivir en Salsipuedes, tierra de ilusión donde el amor nunca se muere, ven, ven y verás de corazón a Salsipuedes, y tu cantarás con gran amor a tus quereres.

La múcura - Porro

La múcura está en el suelo mamá no puedo con ella, me la llevo a la cabeza mamá no puedo con ella.

Es que no puedo con ella, mamá no puedo con ella.

Es que no puedo con ella, mamá no puedo con ella.

La aceptación paulatina de las músicas costeñas empezó a reforzarse en las ciudades, incluso, con los usos públicos que se hacían de ellas. Santamaría-Delgado referencia lo siguiente: «Llama la atención ver cómo para las elecciones presidenciales de 1946, las campañas del conservador Mariano Ospina Pérez y del liberal Jorge Eliécer Gaitán usaron la música de porros costeños en varias manifestaciones populares» $(2014,124)$. No es de extrañar que gracias a acontecimientos de esta índole los ciudadanos sintieran una tácita aprobación y convinieran en seguir aceptando y utilizando porros, cumbias y

exclusiva de las colombianas. Al observar el antes llamado "folklore" cubano, se advierte que, en el punto cubano por ejemplo, temas y tratamientos estilísticos de este estilo son recurrentes.

${ }^{40}$ El crítico musical Iván Benavides comenta acerca de este mapalé: «Cuando Lucho Bermúdez compone "Prende la vela”, las élites de nuestro país rechazaban la música tropical. Mientras el maestro mencionaba a los negros como "vigilantes de nuestros movimientos artísticos y espirituales", Enrique Santos Montejo, Calibán, director de El Tiempo, escribía con desdén acerca de su música, a la que definía como "una merienda de negros"» (2014, s.p). 
demás aires tropicales en distintos festejos populares o en las tradicionales fiestas familiares.

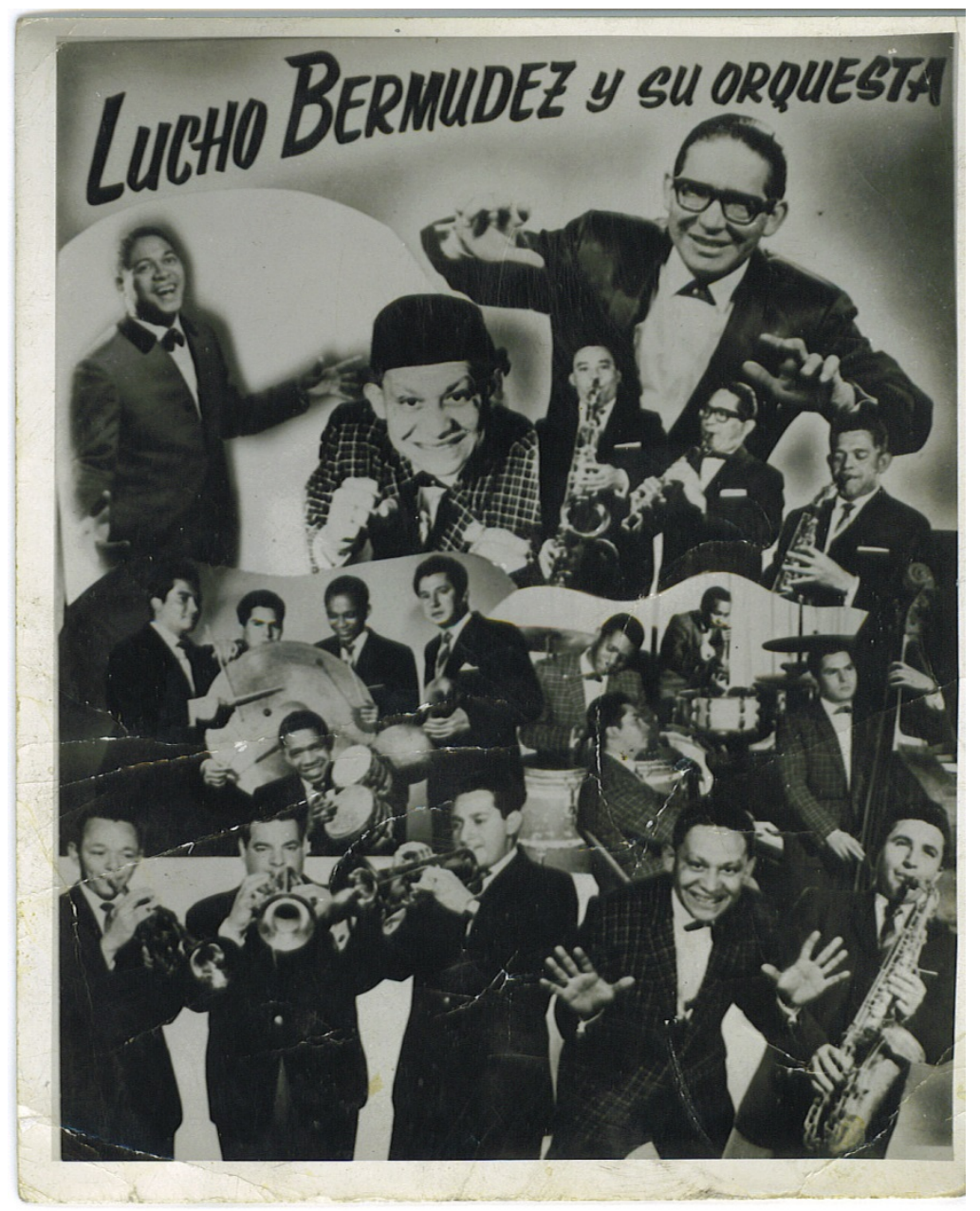

Figura 1. Lucho Bermúdez y su orquesta. ${ }^{41}$

En este vuelco se deslizó una identidad nacional hacia la música tropical con el afán de naturalizarla en la alegría y con la intención de que fuera capaz de mitigar, de alguna manera, semejante trozo de historia sanguinaria alojado en la memoria de la población colombiana:

Colombia construye su identidad nacional — imaginada ${ }^{1}$ — desde la alegría, la rumba, la música y el baile. Es una nación "rumbera”" y resulta por lo menos sorprendente que embebida en una guerra civil que pareciera eterna, con el conflicto social abierto más

\footnotetext{
${ }^{41}$ Foto de la Fundación Lucho Bermúdez, cortesía para la Biblioteca Luis Ángel Arango de Bogotá en el homenaje realizado por los cien años del natalicio de Bermúdez en 2012. Puede verse en la WEB de Banrepcultural, bajo el título: «Concierto homenaje al maestro Lucho Bermúdez»: http://www.banrepcultural.org/prensa/boletin-de-prensa/concierto-homenaje-al-maestro-lucho-berm-dez.
} 
largo y que ha derramado más sangre en el continente, se identifique de esta manera. La “encuesta mundial de la alegría” confirma plenamente este hecho ubicando a Colombia, durante los varios años que se ha realizado el estudio, en los primeros lugares en el mundo (Blanco Arboleda 2009, 104).

Según Darío Blanco Arboleda, el fomento de este giro musical identitario se produjo prioritariamente desde la institucionalidad del Estado. Contrariamente, Wade afirma que el giro está sustentado en el «capitalismo musical» y su poder de generar «comunidades imaginadas», ${ }^{42}$ en el cual son cruciales los procedimientos de la industria discográfica, cinematográfica y radial:

Un rasgo crucial de la música del Caribe colombiano es su comercialización que, lejos de ser caso único, constituyó parte de la tecnificación, masificación y mercantilización de los medios de comunicación tanto en Colombia como en el mundo. De 1930 en adelante la radiodifusión, los discos y el cine colombianos se convirtieron en productos comerciales seguidos por la televisión en la década del 50. Se hace necesario, por tanto, abordar el problema de cómo ciertas tecnologías de comunicación cambiantes, especialmente las de la industria musical, han mediado en la tensión que se da dentro del marco nacional entre homogeneidad y heterogeneidad cultural (2002, 35).

Fomento que no se ha visto segregado por la evolución de las músicas que en principio lo sustentaban. En los años noventa con la invención del tropipop, ${ }^{43}$ por ejemplo, las músicas colombianas tropicales dirigieron la fusión del vallenato o la cumbia hacia los estilos rock, electrónico o pop. De esta forma se alcanzaron públicos juveniles que acudieron en multitud a la actualización o modernización de los tradicionales aires musicales costeros. Para Blanco Arboleda, todo este proceso ha amparado una lógica de pensarse como colombiano bajo una intencionalidad que conviene a los aparatos del

${ }^{42}$ El concepto de «comunidad imaginada» utilizado por Blanco y Wade fue definido por Benedict Anderson (1983) para hacer referencia a las conciencias nacionales. Los miembros de una nación, aún sin conocerse, sienten que pertenecen a la misma, por medio de una realidad simbólica alimentada por los medios masivos de comunicación. Para Anderson, la comunidad imaginada es vital en la fundación de la nación moderna.

${ }^{43}$ Uno de los exponentes del tropipop más afamados nacional e internacionalmente es el cantante Carlos Vives. Un poco en concomitancia con el pensamiento de Blanco Arboleda, Egberto Bermúdez sostiene que desde los noventa «las estrellas del pop colombiano», ya de la vertiente de la industria internacional de la pop music, aunque intentan hacerse a una postura política, no logran manifestar la pesadumbre del conflicto colombiano: «Carlos Vives (1961) y Juan Esteban Aristizábal (1972) -conocido como Juanessurgieron de los dos polos del pop latino, Miami (Sony) y Los Ángeles (Warner) respectivamente, y se consideran representantes de las culturas regionales costeña y antioqueña. Sin embargo, sus inanes textos están lejos de articular las duras realidades colombianas como lo hacían las coplas o como hacen los llamados «corridos prohibidos» y la «música de despecho» para la población marginal en las zonas de frontera asediadas por el narcotráfico y múltiples formas de violencia» (Bermúdez 2010, 256). 
gobierno: evitar la reflexión, la crítica y la acción de la gente ante el desorden instituido a través de las violencias engendradas a partir del siglo XIX. Al respecto, expresa:

El Estado colombiano, su Ministerio de Cultura y los medios masivos de comunicación incentivan y mantienen esta propuesta sonora asociada principalmente a la alegría caribeña. Donde no hay lugar para mayor reflexión, denuncia o simple enunciación del grave conflicto social. Se usa la música como un sedante, distanciador y velo sobre la dura realidad nacional. Por esto los grupos de rock con letras fuertes, con preocupaciones y denuncias sociales, no encuentran mayor eco en la "industria cultural” nacional y se ven obligados a buscar nuevos públicos fuera de las fronteras (Blanco Arboleda 2009, 116).

Pero desde la observación de Blanco Arboleda se evidencia una diferencia considerable y es que la salsa, por el contrario, sí tiene un desarrollo temático que ahonda en las problemáticas de la realidad urbana de los lugares que la producen y la escuchan; realidades que son familiares en el contexto latinoamericano. Aunque el género salsero aborda también el asunto de los temas amorosos, no se limita a ello como lo hacen el tropipop o la salsa balada, que poseen desarrollos textuales y musicales muy diferentes, $\mathrm{y}$, en ocasiones, con públicos distintos. (Ambos géneros se comercializaron en gran medida durante los años noventa). Vale recalcar en contraposición a su postura que a pesar de la festividad de la música y, a veces, a la gracia con que se interpretaban las canciones, la salsa, lejos de esconder la realidad adversa, dibuja la vivencia cotidiana de la calle. ${ }^{44}$ Por lo tanto, las prácticas con el género sí han alentado la enunciación y denuncia del conflicto social, cultivando una mirada crítica sobre la vivencia popular, como también lo hicieron otros géneros en Latinoamérica. ${ }^{45}$ En Bogotá se promovió este tipo de pensamiento en la escucha salsera cuando se verificó un vuelco en la vivencia de la rumba, aspecto que trataré más adelante.

\footnotetext{
${ }^{44}$ En el capítulo cuatro se presenta un análisis de la letra de «Juanito Alimaña». Si bien la festividad de la música, y en este tema la gracia con que Lavoe lo interpreta, el contenido lírico, lejos de esconder la realidad adversa del barrio, dibuja la vivencia cotidiana de la calle. Se observa así que las líricas salseras sí pueden alentar la reflexión, denuncia y enunciación del grave conflicto social; «Juanito Alimaña» tiene mensajes explícitos y conecta con eficacia realidades y sentires de la gente del barrio.

${ }^{45}$ Obviamente, el reflejo del barrio, el mundo callejero y la vida del arrabal se revelan también en géneros latinoamericanos, entre ellos el tango o la ranchera.
} 


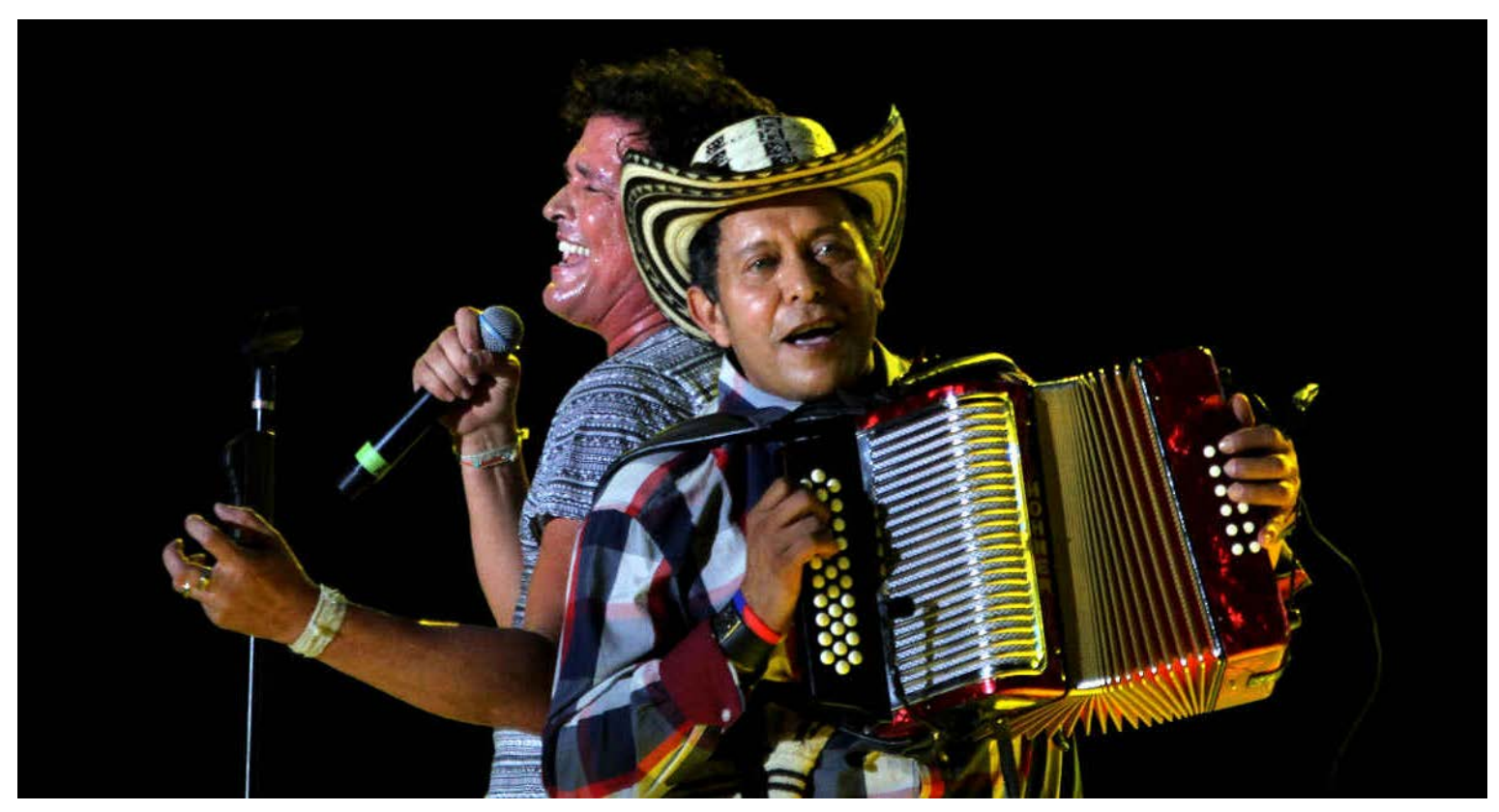

Figura 2. Carlos Vives y Egidio Cuadrado. ${ }^{46}$

Con su narrativa y la vitalidad caribeña de sus ritmos, la salsa encontró en Colombia un gran asilo. Quizás porque se necesitaba «subir el ánimo» en un país abatido y, también, porque paulatinamente éste había sido llevado a un estado de inercia emocional, en el cual no se osaba expresar abiertamente y a viva voz las resistencias a la degradación social y a un sistema económico opresor, pues las prácticas de protesta o mitin en el país son bastante dispersas. Sin embargo, sostengo que la salsa tiene un perfil que comulga perfectamente con la llamada música tropical colombiana, que permite la consolidación de la idea acrisolada de «la alegría de los colombianos». Con el vuelco identitario hacia las músicas tropicales a mediados de siglo, la salsa dispuso de un acervo musical que la sustentara y pudo asentarse en el gusto y la emocionalidad colombianos.

\subsection{El barrio latinoamericano en los géneros populares}

La apropiación de la salsa tuvo un factor contextual indispensable para su realización. Las transformaciones propias de las ciudades latinoamericanas desde finales del siglo

\footnotetext{
${ }^{46}$ Carlos Vives y Egidio Cuadrado, el acordeonista de su agrupación en 2013, en la cuadragésima sexta versión del Festival de la leyenda vallenata. Fuente: Archivo fotográfico El Tiempo.com.
} 
XIX se basaron en grandes migraciones de la gente del campo a la ciudad; verbi gratia el periodo de La Violencia en Colombia referido anteriormente. Los procesos migratorios generaron una urbanización de proporciones desmesuradas cuyo método instituyó la localización y el asentamiento de las poblaciones de manera visiblemente estratificadas. Las zonas de mayor concentración demográfica dieron lugar a la alegoría de «el barrio»; lugar donde floreció la cultura popular moderna en medio de un intrincado sistema de mestizajes e hibridaciones socioculturales. ${ }^{47}$ Paralelamente y a modo de reflejo tardío de lo que pasaba en Europa, los estados construían el ideal nacionalista de los países latinoamericanos. Ideal que, además de definir los supuestos válidos de raza, religión, costumbres, tradiciones, símbolos e historia, por mencionar solo algunos, e invalidar otros tantos, se inspiró también en artefactos culturales identificatorios; entre los cuales el gran privilegiado fue la música que germinó en los barrios populares latinoamericanos.

Con este panorama, en la construcción de las músicas nacionales el barrio latinoamericano que empezó a perfilarse a principios del XX, tuvo una injerencia vital. Peter Wade señala:

Durante este tiempo un extendido nacionalismo cultural se expresó como nacionalismo musical. En parte porque los círculos de la música erudita incorporaron elementos "tradicionales" (Behague I996), y también, cosa mucho más importante, por el surgimiento de estilos nacionales de música popular: tango en Argentina, samba y maxixe en Brasil, danza en Puerto Rico, ranchera en México, son y rumba en Cuba, y así sucesivamente. Generalmente se trataba de estilos musicales surgidos en los barrios obreros de las ciudades latinoamericanas, muchas veces adaptando estilos europeos y combinándolos con elementos rítmicos y estéticos de origen africano (y en menor medida, amerindios), que eran asimilados, modernizados, "limpiados" por las clases medias y convertidos, de esta manera, en símbolos nacionales aceptables (Wade 2002, 10).

\footnotetext{
${ }^{47}$ En lugares como Cali, tan cercanos al Pacífico, la gran cantidad de población de ascendencia africana es visible; se sostiene, entonces, la teoría de que la apropiación de músicas con un fuerte componente percutivo proveniente de lo afro y lo afro-cubano fue bastante rápida. En ciudades como Pasto, cercanas a la frontera ecuatoriana, en cuyo país el mestizaje fue menor y la población amerindia es mayor, puede observarse que no solo la salsa sino la música folklórica latinoamericana alcanzó -y todavía sucede asígran acogida en determinados sectores de la población. En suma, los procesos de apropiación conjugan múltiples variables que van explicando la hibridación poblacional y la mixtura cultural.
} 
Colombia no constituyó una excepción a esta regla, ya que en referencia a los aires musicales amerindios o afroamericanos puede encontrarse, en el mismo orden de «limpieza», el de «blanqueamiento», como se observará en lo que sigue. Como he señalado en el sub-capítulo anterior, las músicas costeñas que formaban una parte del tránsito cultural de la Cuenca del Caribe comenzaron a sufrir algunas transformaciones que posibilitaron su entrada al círculo musical del interior, cuyo emplazamiento era más urbano que rural. Como refería antes, las agrupaciones adquirieron un formato instrumental más estereotipado en las Bigbands estadounidenses; condición novedosa para las agrupaciones tradicionales. Dicho estereotipo intervino directamente, no solo la sonoridad, sino la presencia o la imagen de los conjuntos musicales.

En cuanto a las estructuras rítmicas heredadas de la tradición africana a las músicas caribeñas y afroamericanas, como el tresillo, el cinquillo y la clave de son, ${ }^{48}$ éstas hicieron maridaje con la tímbrica novedosa que aportaban los instrumentos de las bigbands en comunión con las armonías propias de jazz. Con estas mixturas se percibía una sonoridad más moderna que cada vez se orientaba mejor al sonido urbano que conocimos en la salsa; un sonido quizás más cosmopolita, «a lo Nueva York». Transformaciones que redituaron evidentemente en la imagen de las agrupaciones. En la misma óptica, la cantidad de músicos «negros» empezó a disminuir en los conjuntos dando más opciones a los músicos «blancos», y así sucesivamente, de tal forma que la imagen acústica y la visual favorecieron el llamado «blanqueamiento de las músicas costeñas» (Wade 2002; Blanco Arboleda 2009; Santamaría-Delgado 2014; Hernández Salgar 2014).

Mas no hay que olvidar que la invisibilización de lo negro en las músicas populares se evidenció en muchos países, y que fue en las clases medias donde este fenómeno se operó con mayor éxito. Sin duda el disco ha resultado ser un aliado muy significativo en el proceso. Pues gracias a la grabación fonográfica los músicos negros podían registrar sus interpretaciones sin temor a ser rechazados. La música se reproducía en casas y lugares de disfrute sin la presencia de los ejecutantes, lo que garantizaba su promoción y difusión. Santamaría-Delgado, a propósito de la presencia del bolero en Medellín y su evolución en el continente americano, expone:

\footnotetext{
${ }^{48}$ Sobre el tema de los elementos rítmicos africanos en las músicas latinoamericanas, consultar Bermúdez (2005a) y Aharonián (1994).
} 
Ciertamente, los prejuicios en contra de las herencias culturales africanas no eran exclusivos de Medellín. La discriminación en contra de expresiones musicales negras era común en otras partes de Colombia, en Cuba y en los Estados Unidos, para citar solo algunos casos conocidos y bien documentados. Esta realidad comenzó a resquebrajarse con la invención de la tecnología de grabación y reproducción del sonido a finales del siglo XIX, puesto que por primera vez en la historia de la humanidad fue posible separar el sonido musical del cuerpo del músico que lo producía. La tecnología permitió "ocultar" la corporalidad y el color de la piel del músico, y por esta invisibilización los músicos negros pudieron acceder a los micrófonos. Esta circunstancia fue fundamental para la difusión del jazz, el blues y varios géneros afrocubanos; el bolero no fue la excepción $(2014,187)$.

El jazz, el blues y, por supuesto, la salsa, engendrados en los estratos más humildes, con un importante componente negro, no son sino el indicio de que las músicas populares del siglo XX se consolidaron en el hibridado tejido de los barrios, y que establecieron posteriormente su hegemonía comercial en las clases medias. Alejandro Ulloa asevera que a lo largo del continente los géneros populares urbanos «sobrevivieron en el bajo mundo proscritos por “la sociedad”» (2009, 257). No obstante, después pasarían a ser el germen de la representatividad de una cultura popular que habría de ser el bastión de las nuevas identidades en la evolución de los proyectos musicales nacionalistas:

Y debemos insistir en el hecho de que desde New Orleans hasta Río de Janeiro, Buenos Aires y Montevideo, pasando por Santiago de Cuba, Matanzas y la Habana, fueron esos lumpen proletariados al lado de sectores trabajadores (con respecto a la plena en Puerto Rico) los creadores de una cultura musical que aunque hoy es usufructuada por la industria cultural transnacional, en sus orígenes surgió de los conflictos y de la lucha por sobrevivir en un medio decididamente hostil. No fueron las clases medias ni las «burguesías nacionales», (con excepción de la danza puertorriqueña y el danzón en Cuba), los forjadores de la «música nacional» en los demás países mencionados. Vale la pena recordar también que estas músicas de ancestro afro y la cultura que representaban, fueron consideradas inmorales, perseguidas por la iglesia católica y el poder, antes de que la industria se apropiara de ellas para convertirlas en preciados objetos de consumo o modas exóticas para las élites, en los primeros decenios del siglo XX. Después de los años treinta pasarían a ser símbolo de la cultura nacional de cada uno de sus países, gracias al cine, el disco y la radio que los proyectaron por el mundo entero (Ulloa 2009, 257-58). 
Luego el barrio es el epítome por excelencia de la cultura popular moderna. En él confluyen las vivencias más personales y colectivas, en comunión con las lógicas comportamentales de unos grupos que pugnaron por hacerse un lugar en las sociedades capitalistas, produciendo artefactos culturales que se encuentran en un constante ciclo de resignificación y transformación. Siendo éste un común denominador de las ciudades del cono sur, en una interesante exhortación sobre la presencia imponente de la música popular urbana en las identidades nacionales de Latinoamérica, Ulloa propone una tesis sobre el postnacionalismo musical, en la cual defiende la aparición de un nuevo cancionero que ya no repare en la recolección de aires o ritmos originarios de cada país. A partir de la definición de cancionero de Carlos Vega como un «repertorio de géneros y no de canciones» aparta la idea de reconocimiento y pertenencia territorial de un género y apuesta porque expresiones como la salsa pertenezcan a un nuevo orden de la modernidad; un orden en el cual la expresión es «global» en toda la dimensión de su significado; debido a que sintetiza, fusiona e hibrida tantos componentes que ya no es posible suscribirle un origen unilateral. Quizás esta idea sobrepase la magnitud de «género transnacional» a la que he recurrido al comienzo de este capítulo y explique en cierta forma ese desprendimiento de la salsa de estructuras tan canónicas. Obviamente, me refiero a la salsa clásica que se contrapone tajantemente a la salsa balada: ${ }^{49}$

Este cancionero está conformado por un repertorio de géneros e interrelaciones entre ellos que dan lugar a nuevos discursos musicales, los cuales ya no se adscriben necesariamente a una nación en particular, como fue lo característico durante la primera mitad del siglo XX cuando cada país de América Latina y el Caribe se identificó con un género propio: el tango en Argentina, el samba para el Brasil, la cumbia para Colombia, el son para Cuba, la ranchera para México... En el cancionero nacional, con el que amanece el siglo XX en el nuevo mundo, cada género está determinado por una estructura constante, o sujeta a muy pocas variaciones. Un tango es un tango, un samba es un samba, una guaracha es una guaracha, una cumbia es una cumbia y no una fusión con otros géneros precedentes o coetáneos. $\mathrm{Y}$ a pesar de estar conectados con formas musicales previas como la contradanza o la habanera, conservan una estructura estable en cuanto género. En contraste, el cancionero post nacional permite no sólo el tránsito de unos géneros a otros, mediante la virtual eliminación de todas las fronteras, sino la redefinición del concepto mismo de género en la música popular (Ulloa 2009, 266-67).

\footnotetext{
${ }^{49}$ Lo que intento expresar es. que la salsa balada sí se somete a estructuras estáticas y sus compositores se abstienen de desarrollos más extendidos o más complejos, igual que en el soneo y en las descargas/moñas; materia a que aludiré en el subcapítulo 2.5 .
} 
Que los géneros populares se consolidaran en los masificados barrios obreros de las ciudades latinoamericanas y se afincaran en el gusto de las clases medias hasta lograr su reconocimiento como representativos de la cultura nacional, ha sido una destacada demostración de las potentes interpelaciones de las músicas urbanas en los contextos identitarios del siglo XX. Con diferencia, la canción ha sido una de las formas musicales más fecundas a lo largo del siglo gracias a su presencia en el amplio espectro de géneros que recorren el continente. Ciertamente, la salsa y otros géneros mantienen algunos tratamientos netamente instrumentales, pero la canción enlaza otras dimensiones de lo representacional que facilitan la atracción masiva por las piezas cantadas. Podemos hablar de la canción salsera y aunque las líricas se elaboren en diversos registros, como se verá en el cuarto capítulo de este documento, es imprescindible la remisión a la oralidad callejera del barrio, inmanente al estilo. Pero, pese a que sea una oralidad callejera, tiene una elaboración poética y dice lo que la gente desea expresar con una peculiar estilización. Junto a las letras, otro elemento que demarca lo barrial en la canción es la figura del cantante. En la construcción de su figura, totalmente cercana al ciudadano común -aunque finalmente mitificada-, el cantante es una extracción del habitante del barrio y la figura es un registro tan metafórico como real del habitante promedio del barrio popular.

Ahora, el sonido callejero musical ${ }^{50}$ no solo es patente en lo lírico y lo vocal, porque el sonido instrumental también está cargado de característicos visos que son eco del mundo urbano latinoamericano. Así, se pueden escuchar expresiones como el sonido de arrabal, típico del tango o la estridencia y brillo de la salsa. Incluso se habla de esas «imperfecciones» en la emisión del sonido, sobre todo de los metales, que algunos salseros suelen designar «sucio». En efecto, el trombón se consolidó como uno de los instrumentos más representativos de la salsa neoyorquina y, degradando a las trompetas, pasó a un primer plano sobre los años sesenta. José Arteaga arguye que el boogaloo fue decisivo para la era del trombón, y que aquellas generaciones del East Harlem y del South Bronx fueron las que apostaron por su sonido, para convertirlo en el sonido latino por antonomasia. Sugiere, igualmente, que hubo estilos distintos:

\footnotetext{
${ }^{50}$ Ulloa elabora una noción de aquellos elementos del barrio que constituyen el ser y el hacer de los habitantes latinos de los estratos populares, incluidas sus expresiones culturales, bajo el nombre de «callejería». En consecuencia, determina también la existencia de una especie de categoría a la que denomina «callejería musical» (2009, 136-38).
} 
El plenero de Mon Rivera, el experimental de Johnny Colón, el montunero de Eddie Palmieri, el rústico de Willie Colón... Y aunque había alguna diferencia de edad entre uno y otro, todos hicieron parte de una generación que rompió a punta de trombón su relación con un pasado simbolizado por las grandes orquestas que tocaban mambo en el Palladium. Pero, ¿por qué un trombón y no otro instrumento? Posiblemente porque su sonido, en aras de la agresividad y la rebeldía, ayudaba a tapar errores de interpretación y también porque, según Palmieri, permitía crear ambientes urbanos. Y es verdad, la nota larga de un trombón puede guardar semejanzas con los pitos de los carros o los camiones, lo cual para un eterno enamorado de los efectos naturales de sonido como $\mathrm{Al}$ Santiago (creador de Alegre Records) fue "bocatto di cardenale". Rivera y Palmieri grabarían para él, al igual que la Alegre All Stars, siempre con el pionero Barry Rogers en primera línea de acción. Se dice que este estilo "sucio” y tipo soundtrack fue creado por un trombonista de Lousiana llamado Kid Ory, [...] (Arteaga 2013, s.p.). ${ }^{51}$

El sonido «sucio» del trombón, aunque también de la trompeta y otros instrumentos de la salsa neoyorquina, incluidos los violines, son una marca característica en la ejecución instrumental, y podría suponerse que son un sello identificatorio de la imperfección del sonido en resonancia con la imperfección de la vida del barrio.

\subsection{Ciudades, apropiaciones e identificaciones}

La apropiación de la salsa en Colombia presenta matices ligeramente distintos de acuerdo con cada región. Quizás las distinciones más notorias se produzcan entre las ciudades costeras del mar Caribe o del océano Pacífico y las ciudades andinas de interior. Ante todo radican en las formas de recepción, los estilos de baile y las funciones que sus públicos le atribuyeron. Sobre las agrupaciones de música cubana que empezaron a llegar al país durante los años treinta y la recepción que tuvieron en algunas ciudades, José Arteaga narra los casos de Barranquilla en 1939 con la Orquesta Casino de la Playa y, años antes, en 1934 en Bogotá con el Trío Matamoros. El autor aclara que fueron acontecimientos ocurridos durante los inicios de la llegada de la salsa a Colombia, y hay que tener en cuenta que en Bogotá el flujo de estudiantes universitarios de todo el país aún era incipiente. Fue después de dos décadas cuando la

\footnotetext{
${ }^{51}$ Este artículo de José Arteaga fue escrito a manera de reseña con motivo de ilustrar el estilo de la agrupación musical barcelonesa, Tromboranga. Puede consultarse en la WEB de Salsajazz, en el siguiente enlace: http://www.salsajazz.com/index.php/component/content/article?id=503:tromboranga-y-el-sonidodel-trombon.
} 
ciudad recibió universitarios de todas las latitudes, cuyas influencias y gustos empezaron a fijar el movimiento musical de la capital. Arteaga narra lo siguiente:

Lo que sucedió con la Casino en Barranquilla contrasta con la fría recepción al fabuloso Trío Matamoros, cinco años antes, en Bogotá. Los sones de Don Miguel escasamente tuvieron una merecida respuesta en el teatro Faenza de la calle 23 entre carreras 5a. y 7a.

Nunca Bogotá pudo alcanzar el nivel de popularidad de la música caribeña tal y como se manifestaba en la Costa Atlántica. Las presentaciones de los grupos cubanos resultaban tan frías como la Sabana misma, en una ciudad aún habitada sólo por gente del interior. Matamoros pasó casi desapercibido, e igual situación aconteció con el magistral pianista puertorriqueño Noro Morales.

En Barranquilla, por su parte, las orquestas Ensueño y Anacona, los conjuntos de René Cabel, Rafael Hernández y Xavier Cugat, los cantantes Mirta Silva y Bobby Capó, siempre tuvieron el sello de la aceptación masiva. Claro que en este sentido en esta época las visitas de todos ellos a Colombia fueron esporádicas, tanto como lo eran las arriesgadas inversiones de empresarios decididos a traerlos (Arteaga 1990, 85).

Pese a que el autor asevera que «Nunca Bogotá pudo alcanzar el nivel de popularidad de la música caribeña tal y como se manifestaba en la Costa Atlántica», asunto que le refutan otros estudiosos, en la capital sí se originaron formas particulares de apropiar la salsa, las cuales se comentarán posteriormente.

En cuanto a lo musical y en el contexto de los diversos compositores que empezaron a componer salsa en el país, podemos ver cómo esta música producida en Colombia es enriquecida con elementos propios de las regiones. Sobresale tanto a nivel nacional como internacional la labor de figuras como Julio Estrada «Fruko» (n. 1951), Jairo Varela (1949-2012) o Alexis Lozano (n. 1958). Por ejemplo, el cantante y compositor Joe Arroyo (Cartagena 1955 - Barranquilla 2011) imprimió a su estilo ciertos elementos musicales que, según él mismo afirmó, conformaron el joeson, provenientes de la tradición de aires y ritmos del Caribe colombiano. Arroyo describe su joeson en las siguientes palabras:

Para mirar bien atrás, empezó con la canción "Manyoma", que es de Fruko, pero que tiene mis arreglos. Allí nació ese golpe, pero en realidad se hizo fuerte cuando yo llevaba cuatro años con mi banda. Es un sonido que tiene soka, salsa, sonidos africanos, 
cumbia, brisa del mar y un 50 \% que nace de mí pero que no tengo ni puta idea qué es (Silva Guzmán 2004, s.p.). ${ }^{52}$

De cualquier forma, la intensidad con que los salseros colombianos hicieron suyos los ritmos neoyorquinos fue y sigue siendo la misma y algunas ciudades han considerado la salsa como propia. No parezca raro que una ciudad del interior elabore un ideal identitario en torno a la música y que llegue a autoproclamarse: «La capital mundial de la salsa». Lise Waxer elabora un panorama detallado de lo que fue el desarrollo del género en la ciudad de Cali. Con el baile, ${ }^{53}$ la circulación y colección de los discos de acetato, la elaboración de una memoria salsera que identifica la ciudad y las dinámicas socio-urbanas de la gente con la música, Waxer ilustra en una amplia bibliografía cómo se articuló una cultura popular caleña en torno a la salsa durante el apogeo del baile caleño durante los años setenta y principios de los ochenta y antes de su decadencia hacia mediados de la misma década.

Para fines de los setenta, ya se decía localmente que Cali era "la capital mundial de la salsa”. Este reclamo es notorio no tanto en el hecho de que Cali fuera o no la capital salsera legítima, sino en la convicción con la cual los caleños proclamaban que eran más apasionados por la salsa que cualquier otro pueblo del planeta. La inversión emocional con la que los caleños se definieron como aficionados mundiales de la salsa constituía un proyecto para demarcar su posición en el mapa internacional de la cultura popular. (Waxer 2000, 6). ${ }^{54}$

Por su parte, Bogotá exhibía un variopinto panorama sonoro; cosa normal en una metrópoli tan sincrética. Rock latinoamericano y español, rock inglés, metal, funk, tango, bolero, canción protesta, son cubano, salsa, música tropical, entre otros, circulaban asiduamente en la programación radial, eran repertorio de clubes y bares o nutrían colecciones privadas a grande y pequeña escala. En la misma medida, estos géneros comenzaban a protagonizar una ola comercial que se mantuvo muy activa durante dos décadas. En el caso de la salsa, hubo una dinámica muy característica en

\footnotetext{
${ }^{52}$ Este fragmento de entrevista se ha transcrito de la WEB de la Revista Rolling Stone y puede consultarse en http://www.rollingstone.com.ar/584610-joe-arroyoel-rey-no-ha-muerto.

${ }^{53}$ El baile en la ciudad de Cali tuvo un peculiar y muy característico desarrollo, pues los discos de boogaloo en el tradicional acetato, que se presentaban normalmente en $33 \mathrm{rpm}$ fueron acelerados a 45 rpm. Este incremento de la velocidad supuso una danza más rápida y enérgica que comenzó e identificó un estilo propio de baile salsero caleño.

${ }^{54}$ Las producción de Waxer se encuentra consignada también en Cali Pachanguero: A Social History of Salsa in a Colombian City (1998) y en su compilación Situating Salsa: Global Markets and Local Meanings in Latin Popular Music (2002).
} 
cuanto a su uso social: por ejemplo, las fiestas de quinceañeras, las celebraciones de navidad y fin de año, o las habituales rumbas de colegio, barrio, universidad, bar y discoteca, cuyo principal objetivo era divertirse en el círculo social o familiar y conocer potenciales parejas. El uso y consumo del género se estandarizó para este tipo de eventos que tienen una raigambre muy colectiva y grupal en Colombia.

Desde estos usos, en la escucha de la salsa se agenciaron unas interacciones especiales de los jóvenes con su medio y con la ciudad, y la salsa fue un género que demarcó la época juvenil de muchos; en particular con el baile. Hay quienes bautizaron esta época como «La época de Jala Jala». ${ }^{55}$ No obstante, una forma muy visible de apropiar el género se caracterizó porque un sector de la rumba bogotana dio un giro en la funcionalidad misma de la rumba y de la taberna. Exactamente, con el protagonismo de la juventud universitaria y la clase intelectual, la salsa empezó a ser concebida como otro de los emblemas de la revolución social y de la protesta de las clases populares. Así empezó a asociarse con géneros como la canción latinoamericana, con hondas raíces en Chile y Argentina, o la nueva trova cubana impulsada desde la revolución castrista. ${ }^{56}$ Aspectos que ampliaré en el tercer capítulo de este texto.

Sin embargo, en Bogotá y en Colombia en general, la salsa que se conocía a finales de los setenta y en la década de los ochenta tuvo una evolución particular en la cronología de su escucha. Sin la pretensión de generalizar esta evolución, señalo que es muy común encontrar que el fenómeno salsero eclosionó con la llegada de la producción del sello disquero estadounidense Fania, que dio a conocer en el mundo el boom salsero de los años setenta y ochenta. Dicho fenómeno también se alimentó de las eventuales visitas de artistas puertorriqueños, estadounidenses y cubanos a las ciudades de Bogotá, Cali, Medellín y Barranquilla. Hay que subrayar que distintos intérpretes de bolero, tango, música cubana y de la posteriormente denominada salsa, habían comenzado sus visitas en los años treinta, como mencioné anteriormente. Por las mismas épocas, con el auge de la radio empezaba a oírse la música cubana y mexicana en el país. En este sentido es indispensable tener presente que el término salsa alude a la creación musical

\footnotetext{
${ }^{55}$ Se conoce comúnmente como «Jala Jala» el tema que Bobby Cruz y Richie Ray popularizaron a finales de los años sesenta. El nombre oficial de la pieza es «Richie's jala jala» y forma parte del álbum Jala jala y Boogaloo que fue publicado por primera vez en el año 1967. Puede escucharse en https://www.youtube.com/watch?v=mRYvmj8 63c.

${ }^{56}$ De hecho, a finales de los años setenta empezaron a gestarse otro tipo de tabernas que alternaban libremente salsa, canción protesta latinoamericana y nueva trova cubana, entre otros estilos. Los informantes recuerdan a menudo bares como el Quiebracanto.
} 
neoyorquina, procesada a partir de sus orígenes caribeños en mixtura con la sonoridad urbana, a partir de la década del sesenta.

Con respecto al fenómeno que se concebía en Nueva York, César Miguel Rondón escribe que el periodo entre los años 65 y 75 fue una etapa previa de búsquedas, experimentación y primer grado de madurez del sonido salsero. Aclara que la presencia del barrio en la música ya es absoluta durante este periodo, puesto que la salsa emerge de allí, y a partir de este momento ya puede bautizarse con el nuevo apelativo de salsa.

Todo el proceso comprendido entre 1965 y 1970 nos evidencia suficientemente la presencia del barrio. Fue un período confuso, lleno de búsquedas y de no pocos intentos fallidos. [...]. Y en todo el proceso, el barrio fue el hilo conductor. Las letras volvieron a cobrar la autenticidad que habían perdido por culpa del glamour. Los arreglos, lejos de imbuirse en alardes esteticistas, trataron cada vez más de reproducir los sonidos de la calle, ruidos estrepitosos que conformaban la cotidianidad. Y los músicos, que ya no eran ni artistas ni estrellas, surgieron como simples personajes populares, elementos comunes que iban de la calle a la tarima, sin poses ni fanfarronerías. No siempre lo hicieron bien, es cierto, pero también es innegable que jamás dejaron de representar plenamente a todos esos ciudadanos que compartían con ellos la vida del barrio. (Rondón [1978] 2007, 47).

Con lo mencionado, observamos cómo la salsa en las diversas ciudades colombianas se fue articulando sobre la base de elementos comunes en la vivencia popular. Resumo sucintamente los siguientes: En primer lugar, a partir de los años treinta la radio se instauró en el país y las emisoras vehicularon la música caribeña a lo largo y ancho del territorio formando una audiencia que supo percibir matices de la cultura cubana o portorriqueña. En segundo lugar, se articularon elementos musicales cuando los oyentes detectaron los componentes propios de la música cubana en la nueva expresión neoyorquina; en especial la clave del son. En tercer lugar, las ciudades en expansión económica y poblacional concentraron parte de su cotidianidad en la constitución del barrio; reflejo cuasi literal de lo que acontecía en Nueva York. Sobre todo El Barrio neoyorquino suscitó un fuerte sentido de identidad social y de colectividad, por lo cual la idea de «barrio» surtió un efecto de conexión vital entre las ciudades latinoamericanas, Nueva York y la música que dibujaba las vivencias y sentires populares. Aunque veremos en la evolución de esta tesis los aspectos más individuales de la apropiación, que difícilmente se han retratado en los textos sobre la salsa escritos hasta el momento. 


\subsection{La especial cronología de escucha en el país.}

Los antecedentes para la formación de públicos salseros a gran escala en el país, se gestaron en la salsa neoyorquina que recogió y comercializó el sello Fania, como ya he comentado. Posteriormente, los salseros empezaron a mirar en retrospectiva todo el universo musical caribeño; punto de partida de dicho movimiento. La salsa de la «vieja guardia» es aquella que denomina la música caribe, en especial la cubana, referida a los géneros de su tradición popular: mambo, guaracha, pachanga, entre otros, interpretada por agrupaciones y orquestas como Trío Matamoros, Celina y Reutilio o las orquestas de Al Castellanos, Tito Rodríguez, Tito Puente. Además, el término refiere a un cierto tipo social de salsero colombiano que conoce al detalle el desarrollo histórico de los géneros musicales y sus intérpretes y todo lo que rodea su producción musical. Aquellos que se dejaron interpelar por este nuevo universo sonoro y se empeñaron en la búsqueda del conocimiento que traía consigo son denominados «viejaguarderos», amantes de la «vieja guardia». En palabras de Gómez y Jaramillo:

La evolución de quienes se definen como vieja guardia, los más cercanos a la generación que hoy ronda los cuarenta y cincuenta años, empezaron escuchando y disfrutando los discos de la Fania All-Star o de otros artistas más contemporáneos y luego derivaron en su gusto hacia otros géneros musicales anteriores al boom salsero. Es decir, no comenzaron su recorrido por lo viejo, sino por lo nuevo, y de ahí empezaron a devolverse en el tiempo (2013, 92).

En un tono más coloquial, el periódico El Tiempo esboza una crónica sobre las tabernas en Bogotá que resume el proceso de la siguiente manera: «Lo mismo puede ocurrir en El Podium, Salsa Camará, Salomé-Pagana, Café y Libro... y más de 15 tabernas bogotanas que le rinden culto al género salsero de la llamada 'vieja guardia', es decir, del 80 para atrás... pasando por la Fania, hasta llegar al Trío Matamoros» (Navia 2007, s.p.). ${ }^{57}$ Por lo tanto, es común cuando se habla de salsa que los oyentes relacionen la producción neoyorquina, «moderna», con la caribeña, particularmente la de músicas

\footnotetext{
${ }^{57}$ Puede consultarse este texto bajo el título «Así se vive el movimiento de la salsa en Bogotá» en el archivo WEB de El Tiempo: http://www.eltiempo.com/archivo/documento/CMS-3389974.
} 
tradicionales de Cuba y Puerto Rico, aunque perciban y señalen las diferencias respectivas. $^{58}$

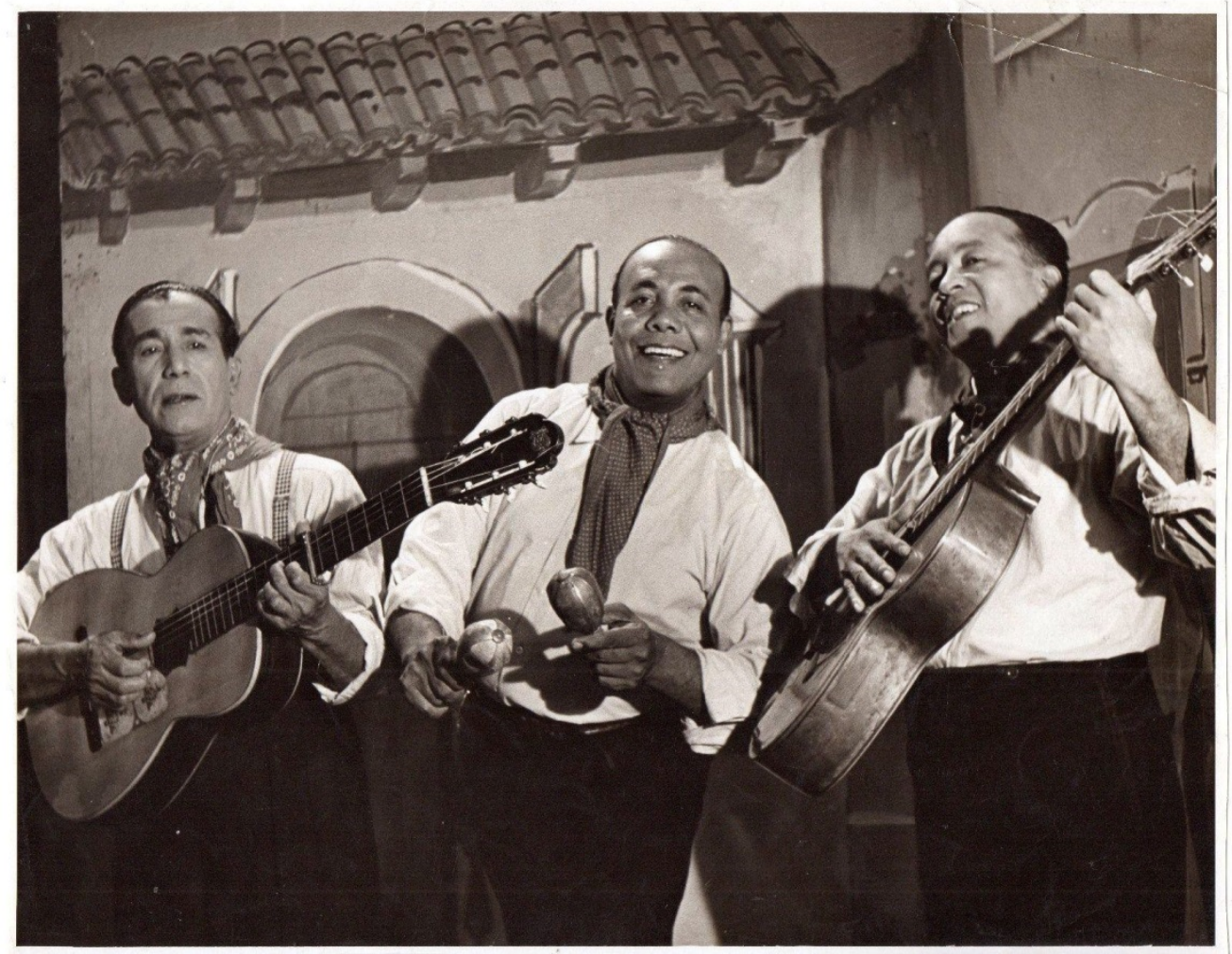

Figura 3. Trío Matamoros. ${ }^{59}$

Los saltos entre distintos ritmos y distintos tiempos históricos que realizan los amantes de la vieja guardia cuando describen el género, se deben a que muchos intérpretes de salsa cantaron también guaracha, punto guajiro, danzón, bolero, bolero-son y canción, por ejemplo. El bolero y la canción son géneros que empezaron a perfilarse en Cuba durante los últimos treinta años del siglo XIX, pero ya venían recogiendo mixturas a lo largo de todo el siglo (Pagano 1994). ${ }^{60}$ Evidentemente, la salsa encuentra su

\footnotetext{
${ }^{58}$ El libro de Gómez y Jaramillo 2013 Salsa y cultura popular en Bogotá describe en detalle los «circuitos rumberos y territorios del goce» que se establecieron en Bogotá desde los años setenta. Ilustra además los que perduraron hasta finales de la década del noventa, de los cuales algunos todavía se encuentran vigentes.

${ }^{59}$ Foto del legendario trío cubano de Miguel Matamoros, La Habana, 1957. Aparte de Miguel, los músicos que lo conformaban son Siro Rodríguez y Rafael Cueto. Fuente: Colección de Eduardo Riestra.

${ }^{60}$ El reconocido experto en salsa y bolero César «Pagano» Villegas, realiza una muy completa serie de programas radiales sobre la historia del bolero que se emite en la emisora Javeriana Estéreo 91.9 FM. Puede consultarse en la WEB de la emisora de la Pontificia Universidad Javeriana de Bogotá:
} 
fundamento en el son, de manera que también es normal para el oyente salsero saltar entre tiempos y géneros distintos debido a la familiaridad de los ritmos. Tanto los inmigrantes del Caribe en los Estados Unidos como las subsiguientes generaciones nacidas ya en este país, portaron los matices propios de estas músicas antecesoras que luego se hibridaron con el sonido urbano gestado en Nueva York. Por lo tanto, se obvia la natural relación entre el son y la salsa que, aunque originados en procesos espaciotemporales diferentes, pueden ser entendidos como géneros autónomos unidos por una familiaridad. No obstante, al referirse a la salsa los oyentes esgrimen otros tipos musicales que si bien no estaban vinculados por la misma familiaridad, marcharon paralelamente a ella como el tango o el vallenato. El reconocido experto Ismael Carreño afirma:

Lo que pasó, en la década del setenta, cuando salió o cuando se le dio, digamos comercialmente difusión al término [salsa], porque el término ya existía, fue difundir con un nuevo vestido toda la música latina; presentarla al mundo, que fue una cosa maravillosa, para nosotros fue magnífico. Magnifico encontrar, por ejemplo, interpretaciones que hace Rey Barreto de La Múcura, encontrar versiones de Pachito Eché por Benny Moré con Dámaso Pérez Prado. Y así, mucha música colombiana. Igualmente pasó con el tango. La Comparsita y los grandes de Cuba, o sea, tú encuentras La Comparsita en muchísimas versiones, en Charanga, en descarga en todo (2014, comunicación personal).

Carreño advierte, al mismo tiempo, la normalidad de incluir dichos ritmos dentro del genérico u omnicomprensivo término salsa, incluso la cumbia o el vallenato que se reconocen típicamente colombianos, y es muy interesante en su apreciación, que incluya el «ritmo musical salsa» con esa especificidad, para ser subsumido dentro del gran boom o lo que se denominaría movimiento salsero:

Es que es lógico porque mira: si bien es cierto, el término salsa acoge muchos ritmos, también lo hay como género y como ritmo musical. «Hay un ritmo musical salsa que se desarrolló dentro del boom de lo que fue la salsa». Pero si vamos a hablar de vallenato, tú encuentras mucho vallenato interpretado por orquestas de Puerto Rico. Por ejemplo, La Mafafa que es un tema colombiano nuestro, tú lo encuentras interpretado por El Gran Combo (GC), en las primeras etapas del GC. Matilde Lina tú lo encuentras en una etapa posterior del GC. Don Goyo, también lo encuentras en etapas del GC. Eso por Youtube: https://www.youtube.com/watch?v=3zOf2ahqqhM. 
citar solamente esos tres que son estrictamente vallenato, no tanto Don Goyo pero sí La Mafafa y Matilde Lina. El GC hizo muchísimos vallenatos, vallenatos. Y allí es donde está lo bonito de la salsa. Y es que «el término, como tal, te da la posibilidad de abarcar todos los género y ahí sí no hay exclusión alguna; ninguna» (2014, comunicación personal).

En ese flujo de músicas por el Caribe y Latinoamérica, que no solo marca un tránsito sino una apropiación de músicas entre territorios e intérpretes, se alude al mismo tiempo a los géneros musicales que fueron punto intermedio, indefinido o confuso, en palabras de Rondón, como el boogaloo. Este género alcanzó una producción notable en un lapso de tiempo breve que fue previo al asentamiento del género salsa reconocido categóricamente como tal. Por lo tanto, el término salsa podría estimarse superador de las nociones «boom» o «movimiento» y comprenderse como un encuadre histórico cultural. $^{61}$ En los autores latinoamericanos que empieza a vislumbrarse esta postura, pese a que no se exprese literalmente de esta forma, destacan Vicente Francisco Torres (1998), Umberto Valverde (1981; 1983), César Miguel Rondón ([1978] 2007) y Alejandro Ulloa (2009) entre otros. En efecto, este último subtitula su libro La salsa en discusión con la frase «Música popular e historia cultural».

Con respecto a los comienzos del proceso de apropiación de la salsa y los ritmos caribes en Colombia suele afirmarse que las visitas al país de Richie Ray, desde 1969, cuando se presentó en Cali y Barranquilla por primera vez, sumadas a las de Héctor Lavoe y La Fania a Bogotá, años después, fueron acontecimientos decisivos para la fundación de la salsa en el país. Al respecto José Arteaga $(1990,134)$ comenta: «La primera etapa de la moda salsera en Bogotá comenzó con el concierto de Héctor Lavoe en 1977, que terminó en catástrofe por la batalla de sillas y botellas que se desató. Esa época concluyó con otro concierto, el de las Estrellas de Fania en 1980, el cual también terminó en tragedia por una irremediable falla eléctrica».

\footnotetext{
${ }^{61}$ En la entrevista que mantuve con el experto Ismael Carreño, él sugería que «el término salsa abarca o acoge en su denominación todos los géneros del Caribe, todos, absolutamente todos». Y agrega con respecto a otros géneros latinoamericanos, que «la cumbia colombiana, el sucu sucu, el tamborito panameño, todo el enclave del son cubano, el tango argentino, la gaita zuliana, todo absolutamente todo lo encuentras dentro de ese término que se llama salsa» (2014). De esta forma, da a entender que la música latina que se abre al mundo desde la década del setenta se presenta con esa etiqueta de salsa. Además alude al tránsito de músicas en Latinoamérica no solo en el sentido de que los músicos y las músicas viajaban de un lado a otro sino de que los músicos interpretaban temas propios de otras latitudes. Así, se encuentran temas versionados en múltiples ritmos y formatos instrumentales en diversos países. Desde estas apreciaciones, entre otras, es que debe entenderse que la salsa, más que un nombre omnicomprensivo que agrupa una gran cantidad de géneros, es un marco sociocultural histórico.
} 


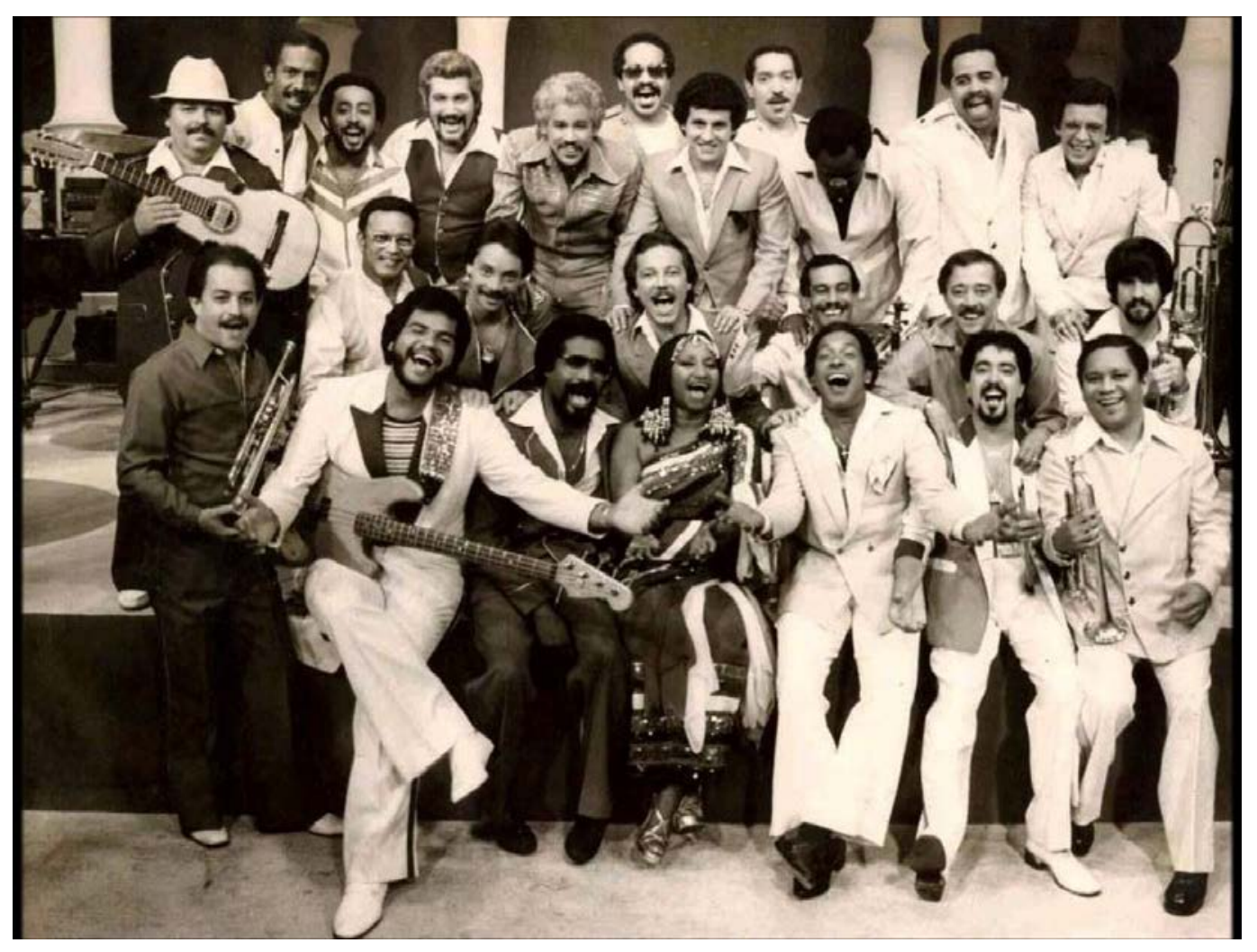

Figura 4. Músicos del sello Fania. ${ }^{62}$

Posteriormente, se evidencia un desarrollo del estilo salsero conocido comúnmente como «salsa romántica o balada» que empieza a oírse aproximadamente desde 1984. Su auge empieza a partir de la segunda mitad del decenio y tiene preponderancia total en el medio salsero ya en los noventa. Hay que añadir que, ante todo, fueron otras las generaciones que se apropiaron del nuevo sonido «dulce» y del nuevo discurso «romántico» de este tipo de salsa. Continúa Arteaga: «La segunda etapa empezó junto a la decisión de Frankie Ruiz de interpretar baladas en Salsa en 1984. Desde ese año no ha parado, aunque el rock en español parece ahogarla. [...]» $(1990,134)$.

Se encuentran variadas teorías con respecto a esta última. ${ }^{63}$ El experto Ismael Carreño señala el origen en el compositor Louie Ramírez y añade:

\footnotetext{
${ }^{62}$ Foto de la Fania All Star de 1979, en gira por Venezuela, justo antes de pasar por Colombia en 1980. Fuente: Fania Records Inc.

${ }^{63}$ Por ejemplo, Nelson Rodríguez (2001) afirma que la balada «Todo se derrumbó» de Manuel Alejandro fue versionada para la Orquesta Versalles por Fitto Foster en 1981, lo que dio lugar al comienzo de la salsa romántica. Foster es un músico cubano mejor conocido como «Palabra». Con esta referencia
} 
No mira, eso fue una venganza [irisas!]. De hecho fue una venganza de Louie Ramírez (LR). A LR lo obligaron a grabar. Un álbum que se llamó Noche Caliente, bajo un contrato que él ya tenía firmado. Entonces, el dueño de ese contrato le dijo: tienes que hacer una serie de arreglos para «baladas románticas». LR, toda la vida fue uno de los máximos... se le llamó el Quincy Jones de la salsa. Era todo un genio haciendo arreglos. [...]. Lo ponen a hacer ese trabajo, y LR, sin mayores pretensiones, creó una «fórmula fácil». Dijo, "no me voy a complicar con esto, hago una fórmula elemental y que le monten la letra y el cantante y chao”. Pero resulta que como la fórmula era tan elemental, fue muy fácil para todo el mundo. Lo que tú miras, los arreglos de música romántica no tienen mayor pretensión musical salvo algunos (2014, comunicación personal).

Evidentemente, este estilo de salsa tiene una elaboración distinta y, si bien no es la norma, no es escuchada por los salseros de la vieja guardia. En las entrevistas a profundidad que realicé y en las conversaciones que mantuve con melómanos y dueños de salsotecas, nunca salió a flote la salsa romántica; y cuando surgió, los comentarios no fueron los más afortunados. Al contrario, en algunas conversaciones casuales que mantuve con jóvenes de entre 20 y 30 años, fue claro el gusto por ese estilo y también por la salsa clásica. Las motivaciones son dispares, y el conocimiento que tienen sobre la músca no alcanza la profundidad del que atesoran los viejaguarderos. Pero destaca que no existe una brecha de gustos por la una o la otra o, incluso, por otros estilos que se han desarrollado dentro del género; por ejemplo la salsa choque, fusión de reggaetón y salsa que nace en la ciudad de Tumaco, en el Pacífico Sur colombiano. Éste es un tema que merecería otra juiciosa investigación, puesto que los jóvenes actualmente escuchan salsa, la coleccionan, la interpretan y la difunden.

controvierte la historia sobre Louie Ramírez, que se ha difundido a lo largo del litoral salsero, aunque por supuesto fue Ramírez el primero en producir un álbum completo en este sub-género: Noche caliente en 1982. Esto indica que hay muchos y distintos antecedentes sobre el origen. Es más, César Miguel Rondón anuncia a Willie Colón como uno de los referentes de la salsa balada desde los temas «Sin poderte hablar» y «Julia». Sergio Santana Archbold hace un seguimiento de diversos artículos sobre el tema publicados bajo el nombre de «Hacia los orígenes de la salsa romántica» que puede consultarse en la WEB de Herencia Latina. También es interesante de este autor el libro ¿Qué es la salsa? Buscando la melodía (1992). 


\subsection{El imperante sentido de la vieja guardia en Bogotá. Programadores y Coleccionistas}

En el subcapítulo anterior señalaba que el concepto de vieja guardia en Bogotá acogió dos corrientes musicales: la de Nueva York que empezó a surgir experimentalmente en la década del sesenta (Ulloa indica que aún desde el cincuenta) y se consolidó en el setenta y la corriente que abarca toda la histórica tradición musical cubana y portorriqueña, de la cual se tienen indicios desde finales del siglo XIX. ${ }^{64}$ Empiezo este subcapítulo retomando esta idea del anterior con el fin de enmarcar dos aspectos ineludibles para comprender el grado de apropiación de la salsa en la ciudad. Un primer aspecto son los elementos musicales característicos de la salsa viejaguardera. Para establecerlos con rigor resulta muy eficaz desarrollar un ligero parangón entre la canción salsera clásica y la balada, solo con el ánimo de diferenciarlos suficientemente de otros géneros salseros. Dicha comparación es vital para identificar los pormenores de algunos elementos constituyentes que son primordiales en la interpelación de la salsa viejaguardera. Una vez establecidos, en un segundo aspecto, se verá cómo al lado de la búsqueda de conocimiento y una significativa red de interacciones en torno a la escucha individual y colectiva, se determinó el sentido de la programación y el coleccionismo en Bogotá. Con esto se introduce la elaboración de mundos de sentido en la salsa viejaguardera que explicaré con mayor amplitud en el Capítulo III.

Si bien ambos estilos se fundamentan en la clave del son, ${ }^{65}$ material definitivo para el género (ver Figuras 1 y 2), las diferencias entre las dos clases de salsa pueden atribuirse básicamente a las siguientes particularidades:

- La peculiaridad tímbrica de las voces de la salsa rosa, de tesituras más agudas y dicción más delicada. ${ }^{66}$

\footnotetext{
${ }^{64}$ Entre los muchos musicólogos y antropólogos cubanos que han investigado y documentado la tradición cultural antillana, la extensa y minuciosa obra de Fernando Ortiz (1881-1969) es un referente obligado para su estudio.

${ }^{65}$ Por añadidura a la clave de son, que tiene dos formas de tocarse, existen también otras claves de las que se vale la salsa en sus composiciones. Las más usuales son la clave de rumba y la clave afro, también con dos formas de ejecución.

${ }^{66}$ Sobre el declive de la salsa Arteaga arguye que las nuevas mezclas han sido estériles: «cuando juntan en un engendro mismo a la influencia del también renegado Michael Jackson [...], los trombones deliciosos y armonizados de Willie Colón y el canto bisexual y andrógino de las voces que aguantan tres números y luego se quedan afónicas de Eddie Santiago, Frankie Ruiz y mariposito plumón» $(1990,15)$.
} 
- El soneo, en esta última, totalmente reducido a la temática amorosa, de frases cortas y medidas, con una expresividad y brillantez bastante limitada en la improvisación.

- En concordancia con su nombre, la temática es estrictamente romántica y no da lugar a la interposición textual o a juegos líricos polisémicos.

- Con relación a la extensión de las piezas, la salsa clásica no escatima en la duración de los montunos o los mambos.

- En la salsa clásica las introducciones son de diversa índole vocal o instrumental.

- Esta última presume de amplia flexibilidad estilística tanto en lo lírico temático como en lo estructural.

- Si se observa la base instrumental, el formato de la romántica suele ser muy estándar, en la salsa clásica pueden presentarse más contrastes; la inclusión de violines y flautas al estilo de los conjuntos de charanga, una cuerda percutiva más extensa y, a veces, la ejecución con piano acústico en lugar del eléctrico, entre otros. $^{67}$

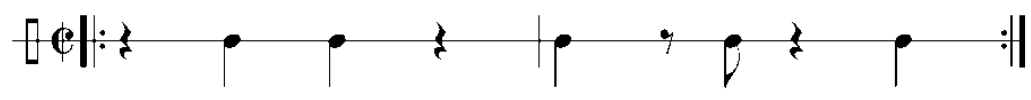

Figura 5. Clave de Son 2 - 3.

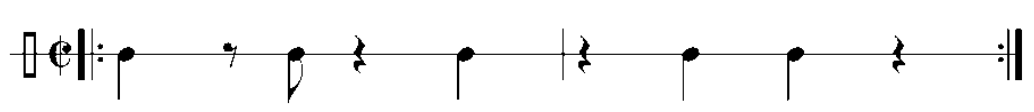

Figura 6. Clave de Son 3 - 2.

No habría lugar en este texto para señalar todos los elementos que enriquecen la salsa clásica y se contraponen a la estandarización de la sala balada. ${ }^{68}$ Es más, en cuanto a la figura de los cantantes y su presentación pública, es evidente la preocupación por una

\footnotetext{
${ }^{67}$ Algunos músicos de salsa dura tuvieron que acoger la salsa romántica con fines económicos. En diversos temas se aprecia que lo romántico del estilo se supedita a la voz del intérprete y a la letra, pero la base instrumental no presenta diferencias contundentes. Ismael Carreño señala por ejemplo que «Anuncio Clasificado», al que si « tú le quitas la letra al "anuncio clasificado”, es un tema de salsa pesada» (2014, comunicación personal).

${ }^{68}$ Christopher Washburne (2002) elabora una descripción bastante precisa de la evolución del estilo romántico, que más vale entender como un género diferente a la salsa clásica que una degradación de la misma. A partir de la intervención de los arreglos de Sergio George la balada se encamina hacia una nueva sonoridad y un estilo en general muy distante del de la clásica.
} 
apariencia muy cuidada, de caras bonitas y el sex-appeal propios para atraer a un público adolescente; al estilo del pop juvenil estadounidense. Los expertos en el tema hacen hincapié, en primera instancia, en esa elaboración de la corporalidad del cantante aunada a una tímbrica consecuente con esa imagen. En segunda instancia es determinante el asunto de la temática romántica aludida en las letras.

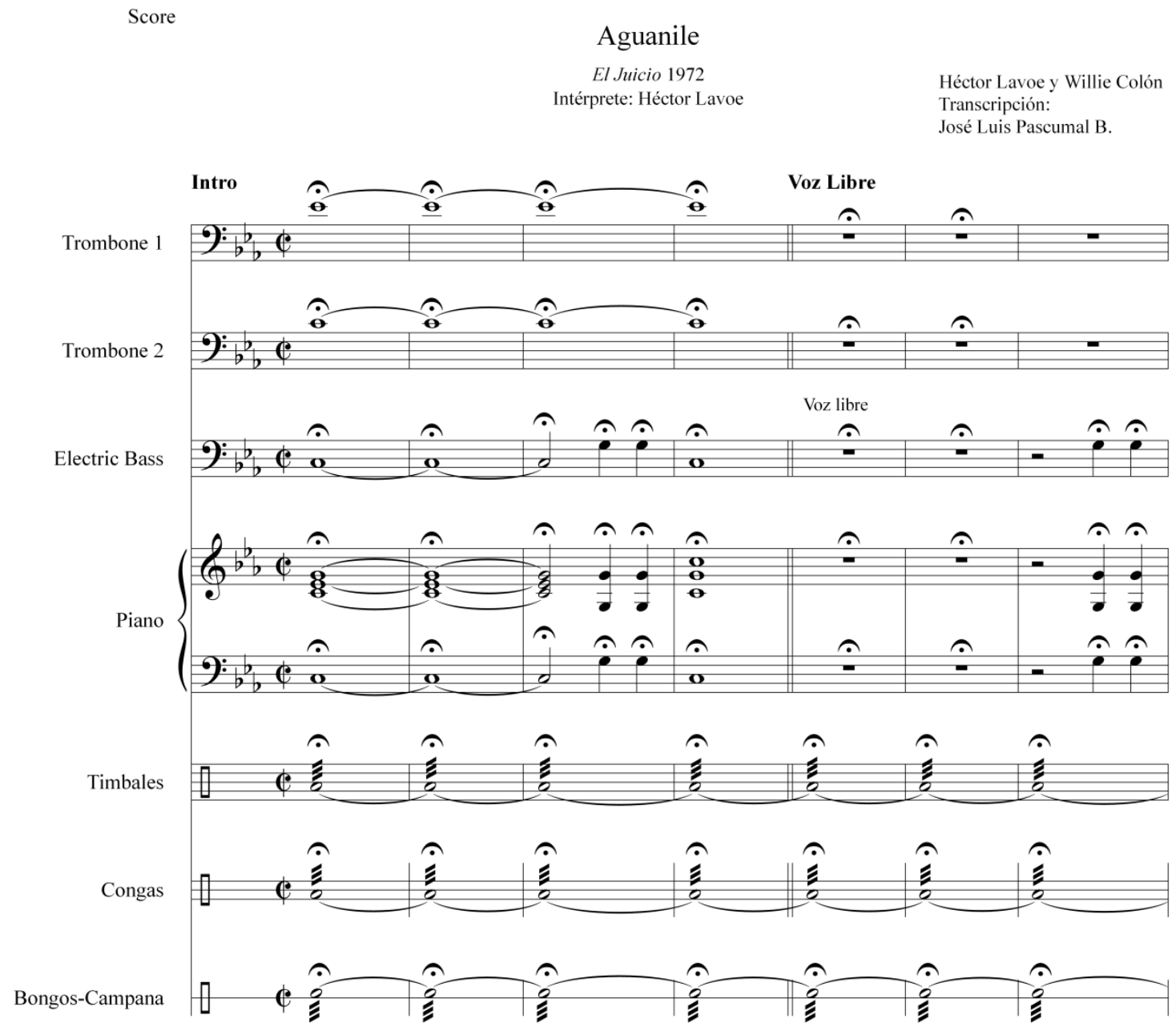

Figura 7. Score del tema «Aguanile» - Introducción. Fragmento.

En la Figura 3 presento un extracto de la partitura de «Aguanile» ${ }^{69}$ con la instrumentación dispuesta para la grabación de estudio realizada en 1972. La pieza es una composición de colaboración conjunta entre Willie Colón y Héctor Lavoe. Su

\footnotetext{
${ }^{69}$ El tema «Aguanile», composición de Willie Colón y Héctor Lavoe, forma parte del álbum El juicio de
} 1972, serie SLP 00424, LP. 
elección se debe a que, según algunas de mis fuentes, es una buena muestra de creatividad compositiva e interpretativa de la salsa clásica. La partitura presenta un formato instrumental sin mayores requerimientos; normalmente, lo usual en Colón. ${ }^{70}$ Los puntos que pueden parecer más atrayentes se localizan en la elaboración, poco tradicional pero bastante minuciosa, de la introducción, que incluye un himno afro (coros a manera de canto ritual sobre una base percutiva) y un leve llamado de los trombones.

Enseguida, el cantante introduce libremente el tema melódico principal con el texto Aguanile. Luego comienza una segunda parte de la introducción, a manera de soneo, con un tradicional trisagio católico (Himno a la Santísima Trinidad: Santo Dios, Santo Fuerte, Santo Inmortal) a libertad del cantante (En la transcripción de la letra anoto ad libitum). Algunos considerarían que ésta es una primera estrofa, pero prácticamente la pieza no cuenta con ellas, sino que consiste en una interesante apuesta estructural sobre la base de un guaguancó, ${ }^{71}$ consolidada en una secuencia de montuno, coro-pregón, más la intervención de otra sección ad libitum del solista. A esto se integran un par de mambos. Aparte de todo lo mencionado, el despliegue vocal de Lavoe es inmejorable. Dicción precisa, tesitura extensísima, fraseo perfecto y un conciso acoplamiento ritmomelódico a la clave. Y para concluir, el laborioso pregón que se detalla en la letra de la Figura 4.

La partitura muestra un formato instrumental básico aunque en la grabación se puede escuchar una introducción que goza de una sección percutiva mucho más compleja; y hay también otras partes de la pieza en las que solo interviene el intérprete acompañado únicamente por esta sección. Por su parte, la letra de la canción toma vocablos y textos de la santería cubana, la religión yoruba en idioma lucumí y la religión católica en idioma español y latín. En la Figura 4 encontramos el desarrollo lírico del tema que presenta la siguiente estructura:

\footnotetext{
${ }^{70}$ En ocasiones, algunas producciones de Colón acogen otros instrumentos de viento-metal como el saxofón. Es el caso de «Gitana», del compositor español José Manuel Ortega «Manzanita», en el álbum Tiempo pa' matar. Aquí incluye saxo tenor, soprano, flauta, violín, guitarra eléctrica, y una cuerda de percusión más amplia, que tiene, incluso una tambora.

${ }^{71}$ El guaguancó es uno de los géneros afro-cubanos que junto al son o la rumba sirven usualmente a las estructuras de la salsa. Para una descripción en detalle sobre la improvisación rítmica de la percusión o el canto solista improvisatorio del guaguancó, ver el artículo de Gerard Béhague (1980) «Improvisation in Latin American Musics».
} 


\section{Introducción}

Dividida en un primer llamado coral al estilo del canto africano de ritual sobre una base percutiva, en el que se invoca a la divinidad de Yemayá. La primera versión de grabación en estudio incluye sonidos ambientales; en especial, simios, aves y elefantes. Sigue la introducción vocal que es una elaboración melódica improvisatoria a cargo del solista.

\section{Montuno}

La sección del montuno es una disposición convencional y normativa, a manera responsorial, entre el coro y el solista. El coro es una oración fija, y tampoco varía en lo melódico-armónico y lo rítmico. Los pregones son otro tipo de improvisación realizada por el solista. Al canto o recitado del solista en el pregón se le da el apelativo de soneo.

\section{Mambo}

En el mambo no intervienen las voces. Es una parte netamente instrumental donde se aprecian las cualidades de los instrumentistas. Se denomina moña cuando es ejecutado por los vientos, y descarga cuando interviene la percusión, el piano o el bajo. Normalmente, los mambos se intercalan con los montunos en varias tandas. ${ }^{72}$ En la versión grabada de Aguanile se aprecian dos secciones de mambo.

\section{Nota sobre las estrofas}

Las secciones específicas a manera de estrofas no existen en Aguanile. En conclusión, no hay estrofas estructurales del tema. Si bien la sección del montuno se dispone dentro de lo convencional del género, prácticamente esta pieza se fundamenta en el ciclo improvisatorio del intérprete y la respuesta del coro.

\section{Nota sobre el soneo}

Otro asunto poco normativo es la manera ritmo-melódica del soneo, ya que en la sección que introduce el tema y en otra sección intermedia, el solista decide improvisar ad libitum. No suene redundante: simplemente que en estas partes el cantante se

\footnotetext{
${ }^{72}$ Debido a su carácter improvisatorio pareciera indefinida la cantidad de tiempo que toma cada una de las moñas o las descargas; sobre todo en presentaciones en vivo. Aunque en el desarrollo de la performance hay señales guías por parte de un instrumentista o del director. En las versiones grabadas, naturalmente se preparan los tiempos y el instrumentista se ciñe al tiempo de rigor.
} 
desapega del acompañamiento ritmo-armónico y elabora su canto a capella sobre la sola base percutiva. $^{73}$

En distintas grabaciones del mismo tema las improvisaciones del intérprete presentan alguna clase de variación; lo que resalta la capacidad creativa en la improvisación textual del cantante. A través de este tema se puede apreciar la diversidad de elementos de tipo temático, sonoro, textual y vocal que pueden integrarse en una sola canción salsera. En el caso temático de «Aguanile» se resumen en una solicitud de protección y limpieza de la casa, dirigida a distintas deidades de diversos credos. Ello forma parte de la santería cubana. Ulloa señala que:

Las músicas “negras” y “mulatas” del nuevo mundo nacieron vinculadas con el mito y el rito sagrado del politeísmo africano, como bien lo demuestran los ritmos de origen Bantú o Yorubá. En efecto, el samba brasilero, la rumba cubana, el guaguancó y ciertas tendencias de la salsa dura, tienen en su origen, conexiones directas con la mitología Bantú o Yorubá, con sus ritualidades comunitarias y sus narrativas orales» (2009, 258).

\section{Aguanile}

Héctor Lavoe

\begin{tabular}{|c|c|c|}
\hline INTRODUCCIÓN: & Oye, to' el mundo reza que reza & al que me critique a mí. \\
\hline LLAMADO RITUAL & $\begin{array}{l}\text { pa' que se acabe la guerra } \\
\text { y eso no se va acaba' }\end{array}$ & Yo tengo aguanile y mai mai \\
\hline VOCES AFRICANAS & eso será una rareza. & MONTUNO: \\
\hline $\begin{array}{l}\text { Oh, oh, oh, Yemayá. } \\
\text { Yemayá... }\end{array}$ & $\underline{\text { МАMBO }}$ & Aguanile, aguanile mai mai... \\
\hline CANTO AD LIBITUM & & $\begin{array}{l}\text { Un judío que a caballo } \\
\text { gritaba sin compasión }\end{array}$ \\
\hline$\underline{\text { SOLISTA }}$ & $\frac{\text { MONTUNO: }}{\text { Aguanile, aguanile mai mai... }}$ & $\begin{array}{l}\text { Oh, Jesús crucificado } \\
\text { muerto por una traición. }\end{array}$ \\
\hline $\begin{array}{l}\text { Aguanile... aguanile... } \\
\text { Santo Dios. }\end{array}$ & Ay tambores rumacuyí & Aguanile, aguanile mai mai... \\
\hline $\begin{array}{l}\text { Santo Fuerte. } \\
\text { Santo inmortal. }\end{array}$ & $\begin{array}{l}\text { tambores rumacuyá } \\
\text { que se echen todos pa'l lao } \\
\text { que la tierra va a temblar. }\end{array}$ & $\begin{array}{l}\text { Eh, a bombonchele } \\
\text { ah, bombonchacha }\end{array}$ \\
\hline $\begin{array}{l}\text { MONTUNO: } \\
\text { CORO }\end{array}$ & Aguanile, aguanile mai mai... & $\begin{array}{l}\text { Aguanile, bendíceme a las } \\
\text { muchachas. }\end{array}$ \\
\hline
\end{tabular}

\footnotetext{
${ }^{73}$ El soneo es una parte primordial del canto salsero; es la sección que remarca la identidad conceptual del tema de la canción y materia de considerable importancia: es lo que define al cantante. Es en el soneo donde emergen las leyendas del canto salsero. A partir de aquí hay también una crítica a la salsa rosa, en la cual el soneo es puramente estándar, y raras veces permite dilucidar el virtuosismo vocal y lingüístico del intérprete.
} 
Aguanile, aguanile mai mai

aguanile, aguanile mai mai.

\section{PREGÓN}

Eh, aguanile, aguanile

Aguanile, aguanile, mai mai

Aguanile, aguanile mai mai...

Eh, Kyrie eleison.

Christe eleison.

no me metas a mi moña

que yo también me sé de eso

Aguanile, aguanile mai mai...
Ay, qué bombonchele

ah, bombonchacha

yo traigo Aguanile

pa' rociar a las muchachas

CANTO AD LIBITUM

SOLISTA

Ay, que los tres clavos de la cruz

vayan delante de mí,

que le hablen y le respondan,

ay Dios, tú ve',
Aguanile, aguanile mai mai...

Ay, aguanile y aguanile, aguanile, dame agua

estoy seco y quiero bebe'.

Aguanile, aguanile mai mai..

\section{МАMBO}

Figura 8. Letra del tema «Aguanile».

En conclusión, todo eso es lo que recoge «Aguanile», demostrando que la santería afrocubana comulga naturalmente con la religión católica venida de España. En palabras de Ed Morales, la confluencia afro en el continente suramericano y el resumen de la santería en el Caribe pueden describirse en los siguientes términos:

La Santería era y es una manera en que los Yorubas adoran a sus dioses encubriendo su identidad a través de los santos católicos. Por ejemplo, el acalorado y lujurioso Changó se fusionó con Santa Bárbara; el complicado intermediario Elegguá con San Antonio. Cada iniciado en la religión se somete a un proceso mediante el cual se descubre al santo de quien debe ser devota su alma. Más que un simple objeto de culto, el orisha que corresponde a cada creyente, realmente "posee" su cuerpo. En los rituales de santería llamados bembés, cualquier variedad de orishas son llamados a "poseer" a los creyentes particulares. Empuñando el atronador tambor batá (así como otros instrumentos que aún hoy no son revelados a los no creyentes), los tambores bembés generan un frenesí que induce al trance por horas. Estos rituales, originados tan pronto como los primeros esclavos llegaron al Nuevo Mundo, todavía se llevan a cabo en la Cuba de hoy (Morales 2003, 4). ${ }^{74}$

\footnotetext{
${ }^{74}$ Santería was and is a way for Yorubans to worship their gods by cloaking them in the identities of Catholic saints. For instance, the fiery, lustful Changó merged with Santa Barbara; the tricky middleman Elegguá with St. Anthony. Each initiate into the religion undergoes a process by which is discovered the saint to which his or her soul should be devoted. More than just being objects of worship, the orishas corresponding to individual believers actually "own" their bodies. In the Santería rituals called bembés, any variety of corresponding orishas are called down to "possess" individual believers. Wielding the thundering batá drum (as well as other instruments that today are still not revealed to nonbelievers), the
} 
Sin la intención de sentenciar que la salsa viejaguardera sea la más importante, la más escuchada o la más trascendental del género musical, puesto que las observaciones de esta tesis apuntan a la vivencia salsera de los jóvenes durante los ochenta y sus prácticas de escucha hasta hoy, debo anotar unas últimas diferencias con la salsa romántica, estilo que actualmente es más escuchado por las audiencias jóvenes. La figura siguiente, número 5, es un extracto de la partitura del tema de salsa romántica «Tú me vuelves loco» ${ }^{75}$ interpretado por Frankie Ruiz (1958-1988). Tomando como base la grabación de 1993 puede observarse que se anexa una sección de trompetas en Si bemol y un trombón más; el resto de la orquesta es igual que en el tema anterior. ¿Dónde radican las diferencias más evidentes? De entrada, la introducción instrumental del tema toma en sí la misma melodía del coro en un juego pregunta-respuesta entre las trompetas y los trombones; (se aprecia concretamente en la partitura) tal como sucederá en el montuno de la pieza, entre el solista y el coro. Es decir, que tanto en la introducción como en el montuno todo se elabora sobre la misma frase melódica. La letra de la canción es abierta por el solista con un pregón recitado -que no se muestra en el fragmento transcrito- y consiste, básicamente, en el título de la canción: «Qué tú me vuelves loco».

Es a través de las características expuestas que los viejaguarderos anotan la estandarización de la salsa balada en contraposición a la salsa brava. Dicen de la primera que es una fórmula convencional a la que se puede adaptar cualquier melodía y cualquier letra. El reputado músico y compositor Willie Colón afirma sobre la salsa neoyorquina de aquella época, viejaguardera desde el punto de vista del melómano actual, y en contraposición a algunas clases de salsa más modernas:

Por más que algunos sabios digan que la salsa es de aquí o de allá o que es así o asá, ellos están hablando babosadas. La razón es que ésta se formó solita. Debido a los ingredientes en el ambiente de Nueva York, que fue un terreno fértil para un proceso orgánico. Las corporaciones y los artistas fabricados de hoy no tienen idea de lo que es la verdadera salsa. «Muchos de estos cantantes, son excelentes intérpretes, y creen que con solo poder cantar bien todo lo demás va caer en su sitio». La verdad es que se necesitan muchas cosas. Hay que conocer las raíces, la música vieja para empezar.

drummers at bembés create a trance-inducing frenzy that lasts for hours. These rituals, originating as early as the first slaves' arrival in the New World, are still held throughout Cuba today.

${ }^{75}$ El tema «Tú me vuelves loco» compuesto por Cheín García Alonso, pertenece a la producción Puerto Rico soy tuyo de 1993, bajo el sello Rodven Records. 
Tienes que tener mucha hambre. Hay que sufrir para poder apreciar el alivio y la libertad de una rumba buena” (Cerón 2013 s.p.).

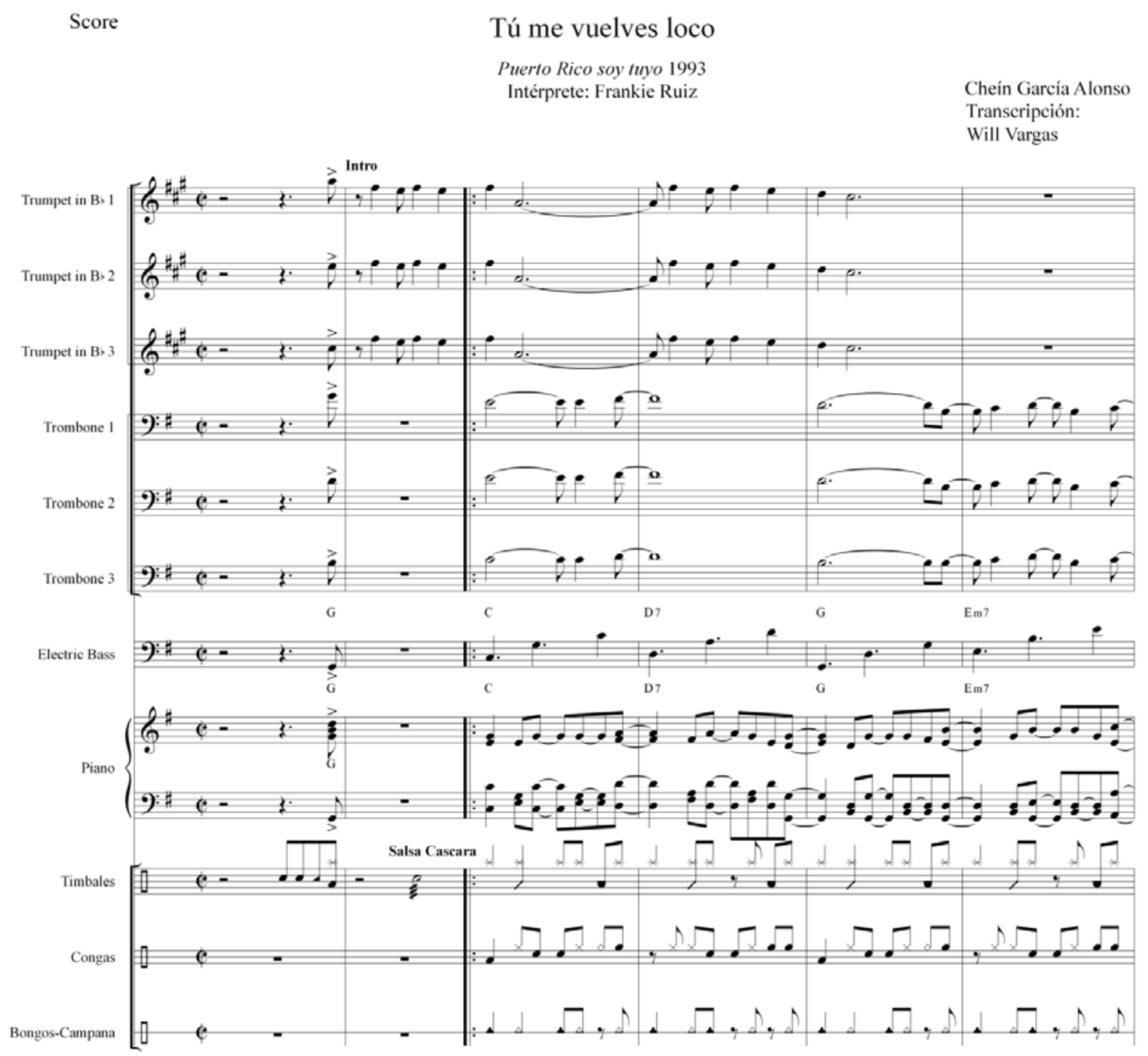

Figura 9. Score del tema «Tú me vuelves loco» - Introducción. Fragmento.

Por añadidura, este estilo de salsa es fácilmente asequible en muchos sentidos. En lo auditivo, es bastante melódico y estereotipado, lo que no obliga mayor competencia para escucharlo y apreciarlo. Los álbumes de esta música, más moderna claro está, se consiguen a granel en el mercado y el formato más usual es el de disco compacto. En la salsa viejaguardera, a excepción de lo producido por la Fania, hay diversos grados de dificultad en el asunto de la consecución de los discos; por ejemplo, los antiguos discos 
de acetato de celulosa son de 78 y 45 rpm, y se encuentran en extinción, por lo cual acceder a ellos suponer diversas dificultades, mientras que los discos de 33 rpm, surgidos durante la década de 1950, se fabricaron ya en vinilo. Así, el comercio de discos es bastante especializado y exclusivo, puesto que no está gobernado por la industria cultural vigente sino por comerciantes particulares que han armado, desde hace muchos años, redes privadas nacionales e internacionales, a veces incluso clandestinas, para obtener y vehicular los discos. Esto dificulta su adquisición y redunda en el alto costo, a veces estrambóticamente elevado de algunas producciones.

Pero para continuar con el ejemplo de la salsa balada, no sería justo omitir que el cantante Frankie Ruiz es heredero de una tradición sonera importante, y en las presentaciones en vivo hacía alarde de sus habilidades pregoneras. Sin embargo, el estilo de esta nueva salsa obliga a los intérpretes a encuadrarse en la estructura y la materia romántica del género. A continuación se expone la letra de la canción con una estructura más estática, en la que el pregón tiene unos parámetros métricos y melódicos muy definidos. Estos parámetros melódico-textuales suelen regularizarse en la salsa romántica en la forma que se observará a continuación; generalmente todos los temas del estilo se presentan con la misma forma.

\section{Tú me vuelves loco}

Frankie Ruiz

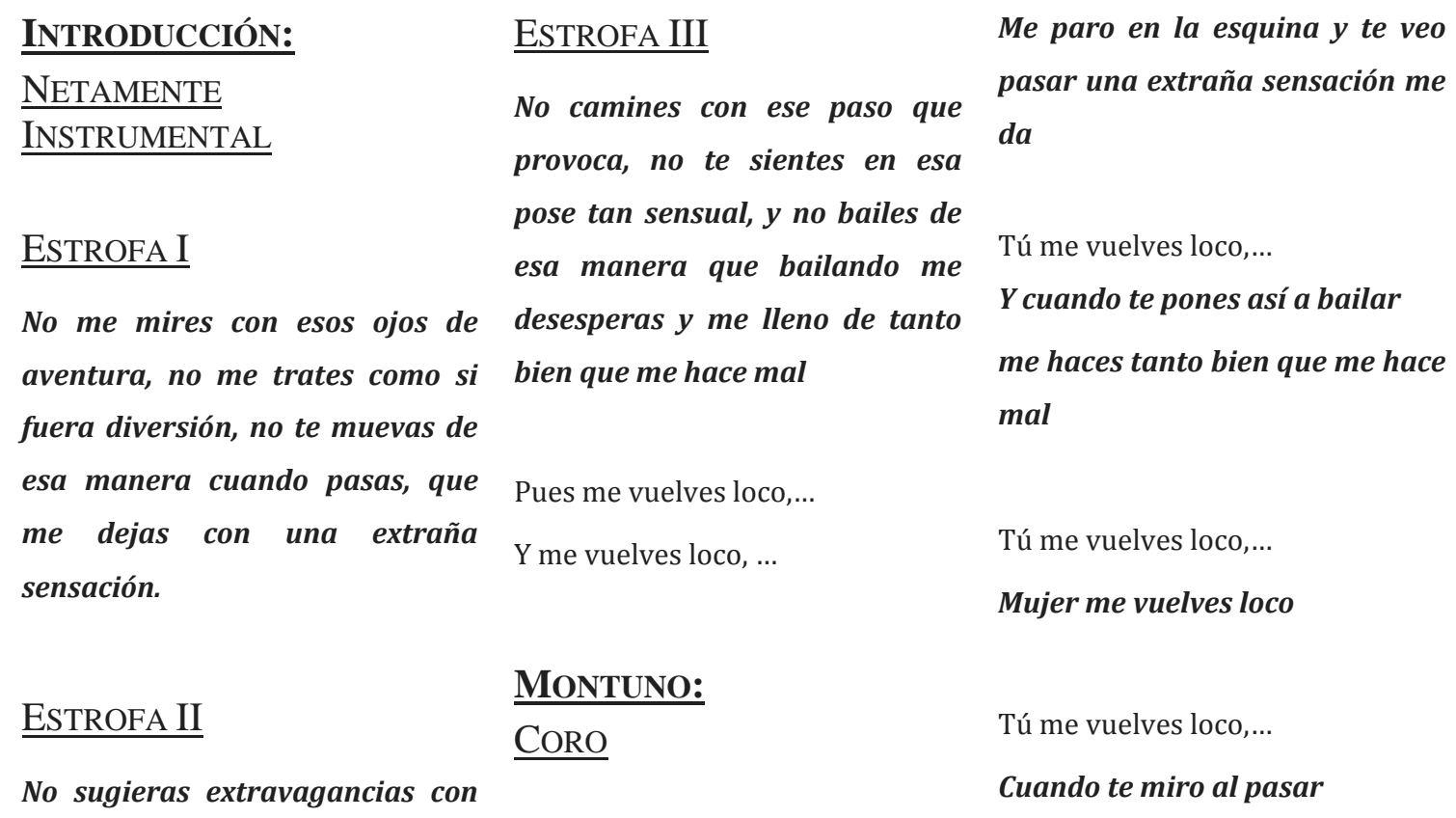


tu risa, no me ciegues la gloria en cada movimiento, que tu juego me mortifica y la vida se me complica, y no quieras saber las cosas que yo invento.

\section{CORO}

INTRODUCIDO POR EL $\underline{\text { SOLISTA }}$

Pues me vuelves loco, tú me vuelves loco, cuando yo te miro china pero no te toco.

Y me vuelves loco, Tú me vuelves loco. Ay, si yo pudiera mama aunque fuera un poco
Tú me vuelves loco, que tú me

vuelves loco.

Tú me vuelves loco,...

Sin movimientos y medio loco.

\section{PREGÓN}

Cuando caminas de esa manera

me vuelves loco corazón

\section{MONTUNO:}

Tú me vuelves loco,...

Tú me vuelves loco,...

Te miro pero no te toco si yo PREGÓN

pudiera aunque sea un poco.

Tú me vuelves loco,...
Mientras camines de esa manera mamita me vuelves loco.

Figura 10. Letra del tema «Tú me vuelves loco».

El tipo lírico de la elaboración textual de «Tú me vuelves loco» no es muy apreciado por los viejaguarderos. Las valoraciones que se escuchan sobre las letras o, a menudo en sí por el mismo subgénero, con contadas excepciones, ponen en entredicho el profesionalismo de los músicos que componen o interpretan ese tipo de salsa. Además, la crítica se sustenta, según ellos, en el detectar falta de creatividad, el afán comercial ligado a la producción económica y el uso de la imagen femenina como objeto sexual. Iván Martínez, locutor profesional y programador durante veinte años afirma sobre la salsa romántica:

No le veo interés y me parece degradante que una canción hable mal de una mujer, y la tome como un objeto sexual. Eso ya no es salsa, eso no tiene razón de ser, eso no es música; [los salseros románticos] están, es, contando una historia sexual. Entonces, a mí ese estilo por eso no me vende, no me gusta, y así haya músicos ahí interesantes, creo que un verdadero músico no se presta para eso. Un verdadero músico sabe a qué va y sabe por qué estudió y por qué pagó un precio en una carrera musical, y no hace eso; no se presta para eso» (Martínez 2014, comunicación personal). 
Aunque los expertos reconozcan que el estilo romántico tuvo raíces antes de los años ochenta con agrupaciones e intérpretes de salsa brava, enfatizan en que la evolución o las derivaciones que tuvo, como lo veíamos en la pieza de Frankie Ruiz, corresponden a una de las tendencias más estandarizadas. Pese a que el cantante es heredero de la tradición viejaguardera, se dedicó a impulsar este último estilo. El programador y bailarín profesional retirado Charly Valencia, que gerencia su propio bar de salsa en el sur de la ciudad, dice sobre el tema:

[...] muy poco salsa rosa, manejo salsa rosa de los noventa hacia atrás, pero salsa nueva, no. Yo manejo lo que es Willie Rosario, Andy Montañez, Gran Combo... aquí somos más vieja guardia, más guatequeros. La salsa rosa ha pegado por el romanticismo que ha tenido siempre. Lo que pasa es que ha habido una degradación; llegó un punto en el que la degradaron: la famosa salsa de cama que llamaron. Ahí comenzó la degradación de la salsa rosa, porque salsa rosa hay muy buena. [...] Uno escucha temas de los nuevos, de ahora y musicalmente, nada que ver, líricamente, nada que ver. El mensaje que da la salsa rosa de ahora es: sexo; sexo o cachos $^{76}$ (Valencia Rivas 2014, comunicación personal).

A partir de estas anotaciones sobre estilos o estéticas se puede confirmar que un importante sector de la audiencia salsera se estableció en el sonido neoyorquino y sus antecedentes antillanos. Los melómanos viejaguarderos buscaron así diversas rutas para encontrar el camino que los llevaría a poseer, conocer, difundir y hasta comercializar la salsa en un intrincado circuito de interacciones alrededor de la música en Bogotá. El afincarse en el sonido viejaguardero implicó resolver el asunto de encontrar más sonido salsero y de saber todo lo que fuera posible sobre él. Las primeras fuentes de información eran escasas, entre otros aspectos, porque no había suficiente literatura sobre el tema en Colombia; aún no la hay, y así se concentraron en la iconografía disquera y la radio que, aunque en principio no era el máximo referente, empezaba a brindar cierta información. También comenzó la búsqueda de fuentes impresas publicadas y la agrupación con personas que tuvieran el mismo gusto por la salsa, con quienes se establecían estrategias de obtención, recopilación y grabación de música en concordancia con sesiones de escucha de vinilos y casetes. El afán por el conocimiento de la historia de la salsa y sus antecesores cubanos y portorriqueños fue un objetivo

\footnotetext{
${ }^{76}$ En Colombia la expresión coloquial «cachos» o, en su forma más completa, «poner cachos», indica ser infiel a la pareja; el que pone los cachos al otro es quien comete la infidelidad.
} 
incontrovertible, y los viejaguarderos hicieron lo que estuvo a su alcance para cumplirlo.

Seguí con la salsa; estudiando, aprendiendo, iba a la [Biblioteca] Luis Ángel Arango (BLAA) a consultar libros, y en todo ese trasegar de música, conocí a lo que hoy es mi bastión, el eje general de mi gusto por la música, y, parafraseando la Biblia, la piedra angular de lo que es la salsa: Arsenio Rodríguez. (A. R.) Eso es un gusto neto por A. R. Me senté en la Luis Ángel Arango, sin saber inglés, a leer el libro de la biografía de A. R., escrito por Max Salazar -está en inglés- y no tenía ni la más mínima idea, entonces, yo era diccionario en mano, y dele... Y tratar de entender cosas, traducir palabra a palabra y después concatenarlas para entender una frase, eso fue lo más complejo. Creo que eso fue uno de mis grandes cursos de inglés, para poder entender un montón de cosas. Porque yo no tenía la más mínima idea de lo que era inglés. Entonces, yo salía de trabajar, en mis vacaciones de universidad, me iba a la BLAA., a las diez de la noche me echaban, me decían; ya vamos a cerrar, ¡chao! Entonces, yo: listo. Cerraba, voy en tal página, al otro día, voy en tal página, seguía, y así fue mi pasión por la música (Sánchez 2014, comunicación personal).

Este breve relato de Enrique «Quique» Sánchez $^{77}$ es el abrebocas para entender cómo se asentó el universo salsero en Bogotá y valga la pena en este punto recordar la evolución del estudio de la música en tanto factor que ayuda a determinar lo cultural: Alan P. Merriam ([1977] 2008, 69) a comienzos de la década de 1960 propone el estudio de la música «en» la cultura; es decir, como comportamiento, ideas y producto humano. Timoty Rice, en una profunda reflexión sobre el «proceso formativo» de la música, se pregunta: «¿Cómo la gente construye históricamente, mantiene socialmente, y crea y experimenta individualmente la música?» $(2001,161) .{ }^{78}$ En el mismo orden, Bruno Nettl (2003) cita a Wolfgang Suppan para indicarnos los caminos en que la música debería ser investigada, debido a su evolución como «comportamiento humano (más que como un conjunto de productos), como parte del universo simbólico humano, y

\footnotetext{
${ }^{77}$ Quique es ingeniero de sistemas y trabaja en una empresa bogotana. La otra parte de su tiempo la dedica a la salsa. Colecciona, organiza encuentros, gerencia la WEB de Mundo Salsero, y continúa escuchando y aprendiendo. No se siente cómodo con ninguna clasificación (experto, coleccionista, melómano) porque dice que encasillarse en un título es una camisa de fuerza. Se dedicó mucho tiempo a la programación musical en bares y discotecas. Además se ha encontrado a gusto dictando charlas y conferencias sobre música cubana.

${ }^{78}$ La reflexión de Rice deriva de la lectura de Clifford Geertz $(1973,301)$ que en La interpretación de las culturas apuesta por una teoría de los sistemas simbólicos en la cual estos «están construidos históricamente, son socialmente mantenidos e individualmente aplicados».
} 
como utensilio». ${ }^{79}$ Cabales reflexiones en este estudio de la experiencia salsera sobre todo cuando constatamos que la salsa en Bogotá empezó a configurar diversos fenómenos de significado y distintos tipos de comportamiento humano definiendo formas de vida en sus audiencias. Para mirar con mayor exactitud el nivel en que se arraigó el género en Bogotá, tomaré como una de las varias vertientes de interacción con el artefacto lo que fue la «profesión» y «oficio» del programador y Dj de salsa en los años ochenta de la capital.

Con el establecimiento de la rumba salsera y la necesidad de ofrecer una programación musical acorde con el espíritu de goce del bailador aficionado -y el bailarín profesionaly por añadidura el ánimo de crear públicos para la salsa, en un proceso de «formación autónoma» los melómanos más conocedores del género empezaron a programar la música de bares y discotecas. En sus inicios la programación fue algo experimental, pero la competencia entre locales propició que los programadores se hicieran al conocimiento del género musical de manera vertiginosa. Ahora, el oficio no solo implicaba saber del género, sino también empezar a conocer el temperamento de los públicos y su evolución en el momento de la rumba. Asimismo, era importante ir agregando piezas nuevas que ampliaran el acervo de los escuchas para enriquecer el gusto musical. En este sentido, buscar el equilibrio entre estos tres factores fue algo que requirió práctica. Fue así como de un ejercicio empírico, pronto se pasó a una actividad profesional. Cuando es profesional ya hay un lugar fijo para trabajar, un local que hay que sacar adelante, un público que va a «rumbear» al cual hay que cuidar, satisfacer y formar, y un salario por la actividad. Bajo estos preceptos, y con un rol claramente establecido, se evidencian ciertas implicaciones disciplinares del oficio y profesión del programador.

Para empezar: Uno. Prevalecía el rigor en la preparación de la música y la profundidad en el conocimiento del repertorio. El programador iba «sonando música» e iba hablando con el público; iba contándole cosas sobre las piezas que sonaban. Esto tenía que ser breve, conciso y certero. Debía cuidar de que el dato que brindara fuera de tal interés que lograra cautivar a sus audiencias. No obstante, esto no podía desplazar la finalidad primordial que era mantener el furor de la rumba en alto; no podía dejar que el ambiente se enfriara o que decayera el ánimo de los bailadores. Como cualquier proceso de

\footnotetext{
${ }^{79}$ El texto citado por Nettl es: Suppan, Wolfgang. Der musizierende Mensch: Eine Anthropologie der Musik. Mainz: Schott, 1984, 26-28.
} 
formación autónoma, hubo también altibajos. Charly Valencia narra su primera experiencia a los 14 años:

Aparte de bailar, a mí siempre me gustó la idea de ser Dj. La primera vez fue por casualidad. Me llevaron a un sitio donde no tenían Dj y me preguntaron: ¿̇sabe poner música? ¡Claro, sé poner música! y me metí a poner música. Hice mi primer oso ¿oyó? Los pone-música son unos, los $\mathrm{Dj}$ son otros. $\mathrm{Y}$ en ese tiempo yo era un pone-música. [...] Yo me metí hacer el oso, lo hice bien hecho, me chiflaron hasta el carajo... Ahí pasé... Porque la música que coloqué en el sitio, era una música que no iba con el sitio. Yo conocía tres, cuatro, cinco, seis temas así de memoria, pero no conocía los Long Play, no conocía los trabajos. Cogía un LP y salía lo que cayera. Pues claro, sonaba el disco más petardo, y la gente... Ahí fue cuando comprendí que para ser Dj, tocaba conocer. Duró unas dos horas, para mí fue una eternidad, hasta que llegó alguien que sí sabía colocar música. [Risas]. (2014, comunicación personal).

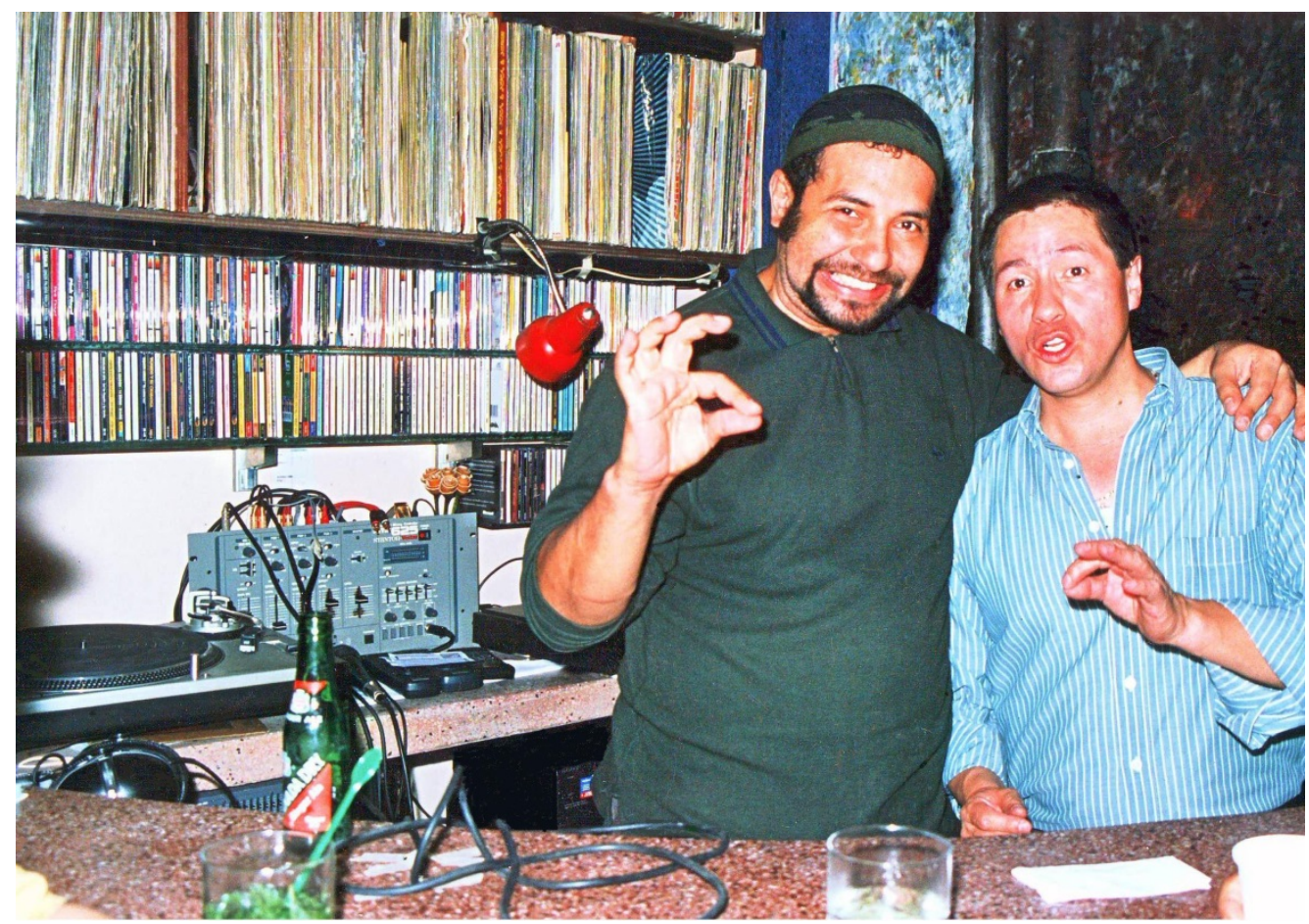

Figura 11. Ismael Carreño. Café Bohemia 1996. ${ }^{80}$

${ }^{80}$ Gary Domínguez, el fundador del Encuentro de Coleccionistas de la ciudad de Cali -a la izquierdajunto al programador y experto Ismael Carreño en el bogotano Café Bohemia en el año 1996, cuando Ismael ejercía como Dj en el mencionado local. Fuente: Archivo personal de Ismael Carreño. 
Dos. Por su parte, Ismael Carreño comenta que tenía que «identificar» el lugar. Un ejemplo: si el lugar se llamaba La Quinta Sinfonía, había que «sonar» ${ }^{81}$ La Quinta de Beethoven en el cierre de la rumba. Esta sinfonía anunciaba a los asistentes que debían preparase para recoger sus pertenencias e ir desalojando el lugar. Pero Ismael agrega que «¡tenía que ser la versión de Von Karajan!» (2014, comunicación personal). ${ }^{82}$ Esto nos advierte de un interés y una necesidad de abastecerse de una cultura general sobre la música. No solo salsa y música caribeña o latinoamericana: «la música en su dimensión histórica y geográfico-temporal». En efecto, Ismael conoce a fondo mucho otros estilos y géneros. Surgió, en esa medida, una clara competencia por el conocimiento entre programadores y entre dueños de locales. Muchas veces para identificar y conseguir el éxito del local los programadores llevaban discos de su propia colección, pues los bares o discotecas tenían colecciones muy elementales.

Tres. La enorme responsabilidad con el trabajo y con el lugar en el que se trabajaba, obligaba a elegir la música más apropiada para ese público y el orden en que debían sucederse las piezas. Esto exigía al Dj estar muy atento a la emocionalidad de los asistentes y a la dinámica de la rumba. Conocer a los públicos que frecuentaban el lugar. El programador siempre estaba atento a la emocionalidad de la gente. Lo que importaba era «sacar adelante» ${ }^{83}$ la rumba; en este sentido el programador fungía como «psicólogo de públicos o colectivos» y en consecuencia debía determinar cómo tenía que ser la secuencia de piezas que iban sonando para modular el entorno anímico del público. El asunto de qué tema y en qué momento sonarlo, eran definitivos. Por lo tanto, el ser programador de oficio y de profesión conllevaba una altísima dosis de conocimiento sobre la melodía y sobre la emocionalidad del público para dinamizar la rumba. Se entiende aquí por qué el programar ayuda a subvertir la sencilla condición de «ser solo un melómano» o un simple "ponedor de música», ya que el Dj se empoderaba con el saber y la experiencia que lo convertían en el líder de la escena salsera en el bar o la discoteca.

\footnotetext{
${ }^{81}$ Puede entenderse claramente que el verbo sonar -forma no personal del indicativo- ha sido apropiado para usarse en primera o tercera persona, dando a entender poner música en el sentido de «hacer sonar algo».

${ }^{82}$ Ismael hace referencia a uno de los negocios de César Pagano, que se llamaba realmente La Quinta Sinfoní,a pero al cual la gente seguía llamando El Goce de la quinta.

${ }_{83}$ «Sacar adelante» fue una expresión muy usual entre los programadores de música. Es un uso coloquial en Colombia que significa conducir al éxito una actividad o una empresa.
} 
Dentro de las interacciones que generó la programación, surge al mismo tiempo una condición para el $\mathrm{Dj}$, y es la de ser transmisor de conocimiento y formador de públicos. Una de las posturas que se asumían en esta condición fue una constante en todos los entrevistados: esa crítica especializada a la que eran sordos. Al no validar el saber desde la crítica especializada, y al no transmitir juicios de valor con respecto a las músicas, facilitaron que los públicos elaboraran sus propios significados sonoros; o mejor, sus propios universos musicales gracias a sus prácticas de escucha. Sin embargo, esta postura no contradecía el anhelo de formar a su público y de inmiscuirlo poco a poco en el conocimiento de la cultura musical que antecede y que engendra a la salsa en sí misma. Mientras el Dj ponía la música, iba contándole cosas a la gente. También iba introduciendo piezas para que su público ampliara el panorama sonoro y para que se fuera enterando de que la salsa era Fania y era más que Fania; de que la salsa era Nueva York, pero era más que Nueva York.

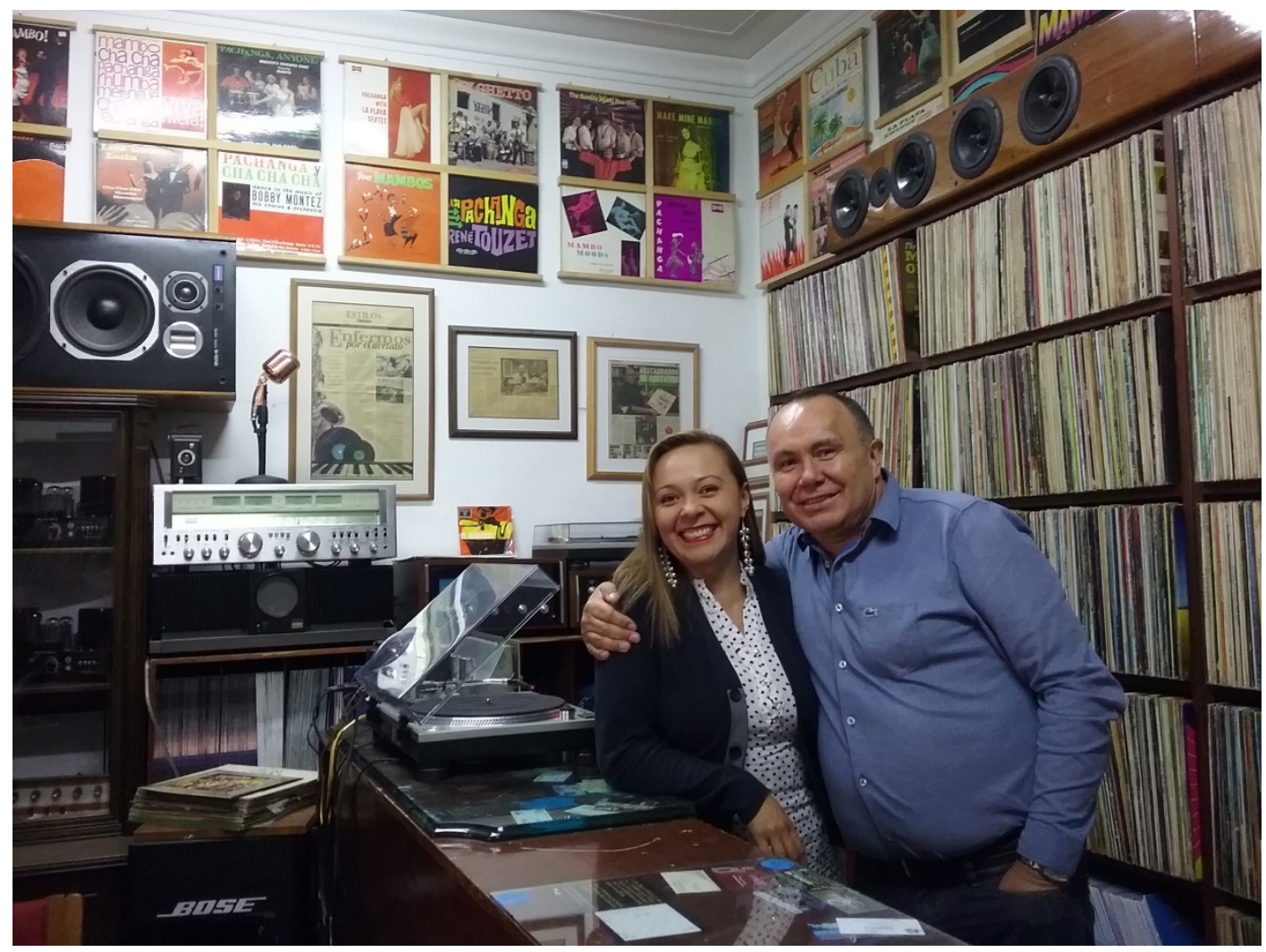

Figura 12. Jenny Pérez y Hernando Gómez. ${ }^{84}$

\footnotetext{
${ }^{84}$ Jenny Pérez, destacada coleccionista del ámbito salsero bogotano, con Hernando Gómez, coleccionista y comerciante de discos, en su tienda de vinilos en Bogotá, el 13 de agosto de 2015. Fotografía del autor.
} 
A partir del rol de transmisor de conocimiento, vemos cómo tácitamente los Dj procuraron que sus públicos alimentaran su criterio como oyentes y potenciales melómanos. En conjunto con esta preocupación se encuentra un afán multiplicador; ¿bajo qué preceptos?: Primero, la idea era que la gente fuera conociendo más música pero con el ánimo de que esa escucha fuera una escucha documentada, que trascendiera más allá de lo sensorial y emocional. Segundo, permeaba un interés muy natural en que se fueran integrando más adeptos a la causa salsera, por llamarlo de alguna forma, y una manera muy conveniente para lograrlo era dar a conocer la música a la par que una información contextual consecuente; histórica en los casos más afortunados. Gracias a esto podemos concebir que hubiera, por añadidura, un aporte en la construcción de universos simbólicos del «otro».

En la misma ruta de la formación de públicos salseros, anoto algo muy importante de la condición del rol docente del programador, por así decirlo, que era intrínseco a su oficio, obviamente, pero que a veces no se visibiliza: la transversalidad de una dimensión ética en el hacer. Si bien la búsqueda del Dj era cultivar un gusto, jamás fue imponerlo. El bagaje que poseía el programador lo hacía acreedor a un poder que le hubiese permitido convencer, imponer, colonizar, descalificar o juzgar. Tal vez en otros espacios, que no el de programar, sí estaba convocado a transmitir juicios de valor sobre las músicas, pero en éste se abstenía. En particular, con todo lo referido al rompimiento conceptual y formal que trae consigo el advenimiento de la salsa balada y que no es motivo de discusión en este texto. Por una parte, la escucha de la salsa se fue cultivando a través de la rumba. En ese sentido, era el programador quien regulaba el proceso de la escucha. Por otra parte, la radio empezaba a cimentar espacios en torno a la salsa; sobre todo de promoción de los productos que la industria introducía al mercado y, a veces, algunos espacios informativos con el fin de educar a los escuchas. En un periodo muy corto la guía sobre la escucha quedó demarcada por la radio. Aunque en ningún momento intento afirmar que solo la rumba y la radio mediaban en la constitución del gusto musical. Lo que tiene que darse por entendido es que el Dj tenía un bagaje amplio sobre la salsa neoyorquina, la música cubana, los aires portorriqueños, en general acerca de la música latinoamericana y, en algunos casos, europea. La cuestión es que favorecía una constitución del gusto muy autónoma en el público. Mas ahora no debemos dar por descontado que en ese momento el acceso a la música estuviera atravesado por otras 
tecnologías y la consecución de discos fuese más compleja. Razón por la cual, podemos afirmar que la gente «se fiaba del Dj» y se dejaba llevar por el criterio de elección que proponía en el lugar de la rumba. Ismael afirma: «En el Dj recaía una responsabilidad y era la formación musical de su público. El público no iba a pedirte música. Nunca. El público esperaba que tú, como Dj, le sonaras la música» (Carreño 2014, comunicación personal).

Hubo una experiencia muy personal e interesante en la labor de Ismael, orientada por la determinación de cultivar el saber de los salseros. Intuitivamente, Ismael desarrolló unas metodologías. Cuenta entonces el caso de Jenny Pérez, quien en aquellas épocas era una adolescente apasionada por el sonido de la salsa y por aprender sobre el tema:

Le decía [a Jenny]: bueno, vas a escuchar esto. No te digo los nombres. Tú me vas a decir en ocho días qué te gustó. Y en esos casetes yo grababa cosas... Por eso es que Jenny tiene una formación musical muy avanzada con respecto a las otras chicas. Jenny te habla fácilmente de artistas que para el común denominador, ni fu ni fa. Porque el referente de ella fue ése: empieza a escuchar con gente que ya tenía un camino bien avanzado (Carreño 2014, comunicación personal). ${ }^{85}$

Con esto se anota que el rol docente del programador se constituía, ante todo, por la posibilidad de que éste ejerciera cierta regulación del proceso de escucha de los públicos, pero aquella regulación estaba imbricada por una dimensión ética. El programador era consciente de que la ética guiaba su hacer pese a que reconociera que su capacidad de criterio era importante, lo cual le podía permitir enjuiciar ciertas maneras de hacer música. Sin embargo, la mayor parte del tiempo no intervenía en la elección de música que podía hacer la gente, y tampoco en la construcción de gusto; pues era sensato y prudente al considerar que la escucha estaba asociada a una circunstancia personal mediada por un tiempo, un espacio, unos personajes y unos afectos.

En síntesis, resulta evidente que por medio de la salsa se generara en los programadores un grado determinado de agencia. Antes de convertirse en Dj profesionales, tal agencia les permitió la construcción de mundos de sentido en la socialización. Enriquecer el

\footnotetext{
${ }^{85}$ Tuve la oportunidad de encontrar a Jenny Pérez unos años después, y en efecto, corroboró este proceso formativo que tuvo con su mentor Ismael Carreño. Hoy Jenny es una de las pocas mujeres que figuran en el cerrado, exigente y exclusivo círculo del coleccionismo salsero bogotano.
} 
gusto musical en las reuniones donde se escuchaban los acetatos que el grupo iba consiguiendo era imperativo y, paulatinamente, lo fue también demostrar lo que se sabía de música. A partir de esta agencia además, al cultivarse como programador, el Dj se constituyó en autoridad y gozó de un prestigio gremial y social por su conocimiento y su quehacer. Entonces, se situó en escenarios sociales de reconocimiento y configuró ciertas identidades desde la plataforma que le cedía su actividad alrededor de la salsa. A su vez, es propicio mencionar que en la conquista de estos escenarios se ha logrado constituir y establecer, con autonomía, el sentido: el sentido de una vida en el conocimiento, promoción y divulgación del género. ${ }^{86}$ Con esto nace la actividad coleccionista de la ciudad que pervive hasta ahora y, de hecho, se potencia cada vez más con itinerarios que ya forman parte de la agenda de instituciones oficiales como el Instituto Distrital de las Artes y que cuentan con eventos en el ámbito nacional.

El coleccionista es una figura icónica en el medio salsero. Su imagen se elabora alrededor de su conocimiento y, por supuesto, de su colección. Personajes de la talla de Francisco Cantor, César Pagano o Hernando Gómez, empezaron a coleccionar mucho antes del boom salsero bogotano, incluso antes de la década del sesenta. Gómez y Jaramillo describen la actividad en los siguientes términos:

La tradición de grandes coleccionistas que viven en la capital cifra lo más preciado de su colección en los formatos de acetato o vinilo, principalmente. Aunque existen coleccionistas de discos compactos, el reputado coleccionista, el reconocido en este medio, es el que colecciona acetatos o pastas. ${ }^{87}$ En relación con el acetato, los coleccionistas tienen muchas consideraciones acerca de sus múltiples virtudes, entre ellas la calidad del sonido, el año en que fue prensado, la artesanía en la diagramación de las carátulas (Gómez Serrudo, Nelson Antonio 2013, 93).

El coleccionismo fue tomando forma como actividad privada y pública en la ciudad. Los eventos se realizan cada vez con mayor frecuencia y mejor organización. Sería posible afirmar que ya es una institución en el medio bastante fortalecida y con miras a ampliarse más. Pero junto con su crecimiento se puede notar que es una actividad muy especializada. Ésta se ha forjado un círculo muy estrecho donde es bastante dispendioso

\footnotetext{
${ }^{86}$ En la actualidad, programadores de antaño como Charly, Iván o Ismael ya se encuentran retirados de la escena de las grandes discotecas. No obstante, continúan su ejercicio de divulgación desde otros espacios. Charly gerencia su pequeño bar o Ismael conduce un programa radial.

${ }^{87}$ Con el nombre de «pasta» se denomina también el disco de vinilo o acetato; mis entrevistados usan este término bastante a menudo.
} 
acceder en calidad de «concursante» o «presentador» de temas en los encuentros. Por otra parte, ha sido una actividad consagradamente masculina; condición que ha comenzado a cambiar desde hace apenas algunos años:

En la salsa y a nivel de coleccionista no he conocido mujeres DJ. Sí se puede decir que a finales de los 90 las mujeres comenzaron a incursionar en los encuentros de melómanos y coleccionistas; de manera muy tímida y con un poco de miedo del rechazo de los señores que, ya afincados en esto, con curiosidad las miraban pasar al frente a colocar sus muestras musicales (Forero 2016, comunicación personal).

La referencia de Claudia Forero, coleccionista que ha alcanzado cierta reputación y estudia la materia documental de la salsa, es muy atinada para la descripción de las interacciones en el ámbito. Forero señala con rigor los baches que hay que sortear en los intrincados caminos del coleccionismo, porque no sería lógico hacerse a la música para guardarla y privatizarla. Su mirada, como la de muchos otros, apunta a la difusión de la música y de la cultura caribe, para lo cual el escenario del coleccionismo es ideal. De todas formas hay que considerar que el coleccionismo estimula factores decisivos para la pervivencia de la salsa en Bogotá, del género musical en sí mismo y para robustecer vínculos socioculturales entre las audiencias salseras.

En la narración de los coleccionistas y los programadores de sus historias de vida en torno a la profesión es posible evidenciar, al mismo tiempo, que la salsa en la Bogotá de los ochenta constituyó articulaciones entre el sonido salsero y múltiples interacciones emanadas de los usos del género y sus prácticas de escucha hasta hoy. El punto del relato de estas historias es vital porque, decididamente, da coherencia a los hechos contados, a la trama argumental que define la vida del programador y que tiene que ser contada para su realización. De esta forma y atendiendo a Ree, citado en Frith ([1996] 2003, 207), ${ }^{88}$ puede suponerse que la identidad personal es, por lo tanto, «la realización de un narrador, más que el atributo de un carácter». Ree apela, a la vez, a Sartre y Ricoeur para sugerir que la narración es «la unidad de una vida», no algo alcanzado gracias a una continuidad esencial sino, por el contrario, mediante una «creencia recurrente» en la coherencia personal, una creencia necesariamente «renovada en el relato de cuentos».

\footnotetext{
${ }^{88}$ El texto citado por Simon Frith es: Ree, Jonathan. «Funny voices: stories, "puntuation” and personal identity», New Literary History 21 (1990): 1050.
} 


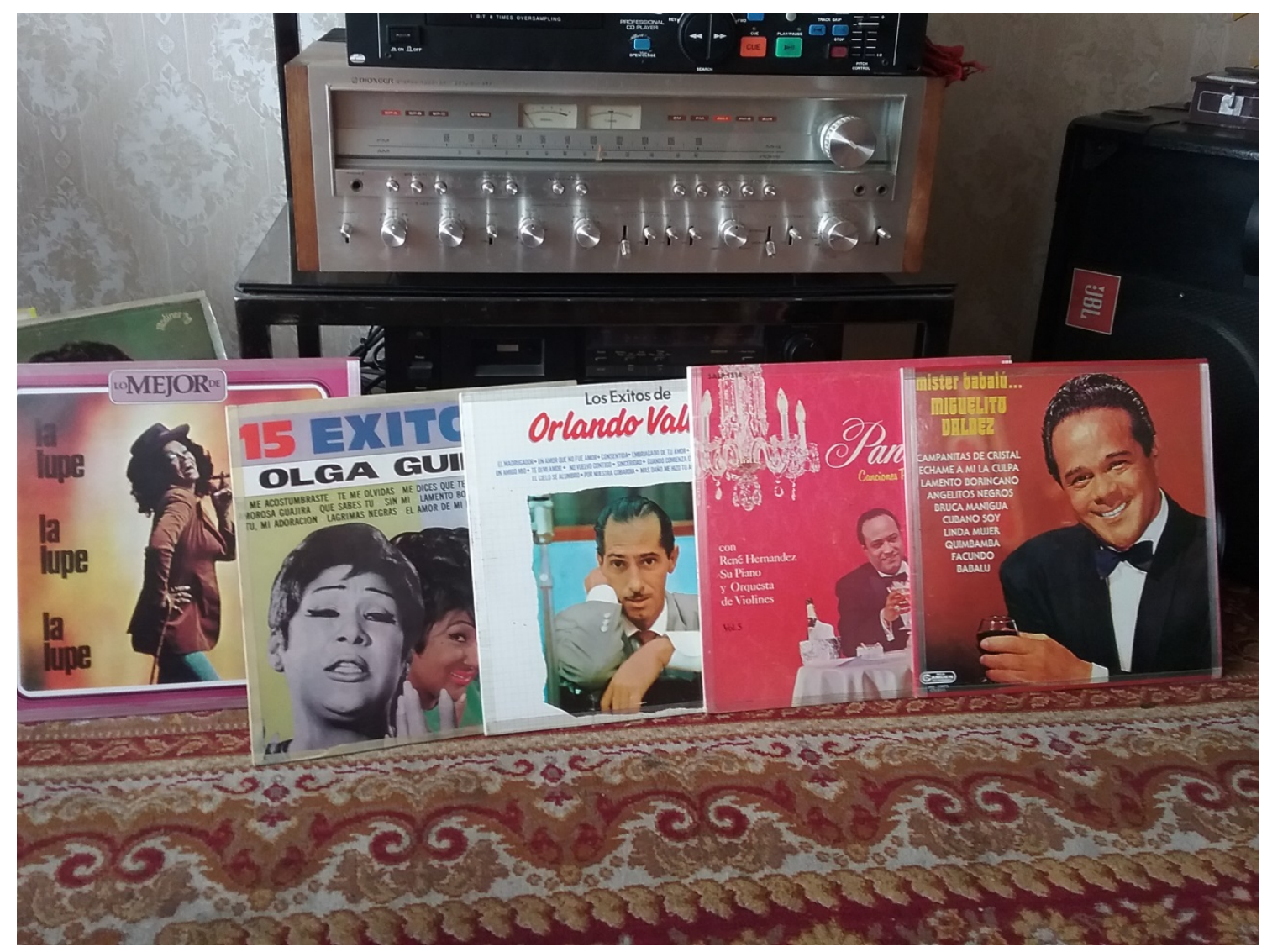

Figura 13. Discos de la colección de Francisco Cantor. ${ }^{89}$

En las cinco secciones comprendidas en el recorrido de este capítulo he establecido cómo la historia política del país abrió paso a la salsa desde la familiaridad que albergaba con los ritmos tropicales colombianos, compartiendo el sentido ya estabilizado o el hábito interpretativo de la alegría que demarcan estos géneros. De igual manera, es importante entender que los orígenes urbanos de la salsa redundan en la construcción de un ideal colectivo de identidad. Tanto en Bogotá como en otras capitales latinoamericanas se ha sabido reconocer el sustrato popular de ciertos géneros y la representación de lo cotidiano, ante todo, en lo que dicen sus canciones. Asimismo, es imprescindible comprender por qué la música de la vieja guardia tuvo un vínculo tan efectivo con los escuchas bogotanos de los ochenta, puesto que dicha articulación ha permitido que la salsa clásica perviva en redes paralelas al comercio que gobiernan las actuales industrias culturales, dinamice prácticas colectivas de intercambio social como

\footnotetext{
${ }^{89}$ Esta foto fue tomada en el apartamento del reconocido coleccionista y experto en historia de la música cubana, Francisco Cantor el día 30 de enero de 2015. Fotografía del autor.
} 
los encuentros de coleccionistas y coadyuve dentro del mismo coleccionismo a otras prácticas. En el coleccionismo se potencia el ejercicio de escucha, se promueve la formación de públicos y se difunde el saber histórico en torno al género. Todo lo anterior constata la magnitud del significado de la salsa viejaguardera en Bogotá y, si bien hoy las prácticas han cambiado y la radio influye por completo la formación del nuevo gusto musical en los oyentes, es evidente que existe, y de manera muy vital, una corriente de salsa viejaguardera que no solo alimenta las culturas musicales individuales, como acertadamente proclama Slobin (1993), sino que procura intercambios culturales que fundan el sentido de una vida social. 


\section{CAPÍTULO III. SALSA Y MUNDOS DE SENTIDO}

En este capítulo se recogen los principales elementos que intervienen en la experiencia estética y en el significado de la vida social en las prácticas de escucha de la salsa. A partir de estos elementos y sus nexos vinculantes se describe cómo se elaboraron y se gestionaron los particulares mundos de sentido en los oyentes. Parte de la preponderante alegría que se desprende del sonido y la férrea sujeción que ejerce sobre el cuerpo para determinar la realización de la felicidad en la música y el baile. Primero, el capítulo localiza a un melómano situado en la escena salsera de la Bogotá nocturna durante la década de los ochenta, y se sirve en cierta medida del relato de María del Carmen Huerta y de diversos informantes que tuvieron una participación activa en la rumba bogotana de la época. Los relatos de María del Carmen, personaje protagónico de la novela Qué viva la música, son un buen ejemplo para comprender la elaboración de la experiencia estética y la realidad no ficcional de aquella época; pues la descripción tan detallada ayuda a establecer la operatoria entre mente, cuerpo y contexto en una vivencia febril de la salsa. Sujeta a tales vivencias, la segunda sección aborda los factores que permitieron modelar la libertad de los jóvenes en la ciudad. La libertad dotó de significado una vida urbana donde calles, lugares y gente en interacción con la salsa proyectaron una manera definida de socialidad.

Después se tratará acerca de la escucha en la intimidad mediada por los dispositivos tecnológicos, gracias a los cuales la música se vuelve portable y su disfrute es privado, pues ya no es necesario acudir al concierto para disfrutarla. Aquí sobrevienen dos aspectos claves para la definición de nuevas estesis. Uno, la desaparición visual de los intérpretes, y dos, la oportunidad de manipular la música en la organización, la repetición o el copiado de las piezas gracias su prolongación en artefactos tangibles. En este apartado se tocará además la estrecha relación de los salseros con la calle 19; (denominada coloquialmente «la 19»), en la cual se funda un circuito de interacciones culturales que culmina en la escucha privada de la salsa en la casa de los melómanos. Luego se abordarán los particulares mundos de sentido orientados desde las necesidades y deseos de los oyentes, los cuales se materializan en los territorios donde transcurre la vida cotidiana. Posteriormente, se pondrá de manifiesto la función de la música como organizadora de temporalidades, que otorga a la experiencia un tiempo en el cual 
transcurrir, por lo que es importante observar su rol dinámico en la gestión de los recuerdos. De esta manera se tendrá en cuenta su influencia en la elaboración narrativa de los acontecimientos que los melómanos cuentan en sus relatos. Finalmente, se destacará el poder de la música en su capacidad de ser re-creada en el interior de cada persona, y reproducida o exteriorizada corporalmente.

\subsection{Música caribeña, tropical y salsa: la realización de la felicidad.}

Al movimiento y energía del ritmo salsero se asocia «lo alegre»; los salseros asocian la dinámica rítmica de la salsa directamente con la alegría. Es decir, como si la tristeza, la melancolía o el dolor no tuvieran realización en el ritmo frenético o cadencioso de la salsa neoyorquina o de las músicas caribeñas. Bajo este precepto, ritmo y movimiento corporales se estructuran en la alegría, mas no en la tristeza. Las emociones relacionadas con la adversidad se diluyen en una práctica consuetudinaria de la negación. Negar la tristeza y el infortunio antes, en y después del baile, y también cuando se habla sobre él: «Bailar hasta el cansancio, no importa si la letra es triste, la salsa es alegría y al bailar uno no se da ni cuenta de lo que dice la canción» (Rosas Salazar 2014, comunicación personal). Cuando se acude a la fiesta para bailar hasta el cansancio, el mundo es reconfigurado de tal forma que todo lo que ocurre es bueno y no pasa nada malo. Es interesante observar cómo ciertos grupos, algunas culturas negras del pacífico o del Caribe por ejemplo, expresan también la tristeza y el dolor a través de ritmos vertiginosos pero sin negarlos; ya que se consuman en ritos para la elaboración de los duelos o para exorcizar los males. Al escuchar y bailar salsa las emociones negativas desaparecen y en su lugar aparecen las positivas; se niega el dolor para que pueda ser sustituido por la alegría. ${ }^{90}$

\footnotetext{
${ }^{90}$ En el artículo «El chico duro de la Habana. Agresividad, desafío y cinismo en la timba cubana» Rubén López-Cano (2007a) observa cómo las canciones de la timba proveen de narrativas e impulsos energéticos de automotivación personal por medio de la exaltación del sexo, la guapería y la fanfarronería, en medio de la crisis más despiadada que despojó a los jóvenes cubanos de cualquier bien material. La timba se concibe como salsa cubana y está en vigencia desde los años noventa. «Un agente fundamental de las canciones de la timba es su trabajo para construir y fortificar el arquetipo cultural del "Chico duro de la Habana". Por medio de este artificio, los jóvenes que la practican son capaces de tejer un complejo andamio semiótico por medio del cual reconstruyen simbólicamente mucha de su frustración, desengaño, impotencia y, sobretodo, agresividad para con el medio social. Uno de los atributos más fuertes del "chico duro de la Habana" es el cinismo con que enfrenta muchos de los problemas éticos y morales que suponen sus estrategias de sobrevivencia. Así mismo, este arquetipo provee de una fuerte dosis de autoafirmación que preserva la autoestima y confianza en sí mismo del oven que participa de él. El cinismo que destilan las canciones de la timba es una estrategia que desarma los
} 
Tal orientación del baile salsero, y en sí de la rumba, se describe con precisión en Que Viva la música. La novela de Andrés Caicedo ${ }^{91}$ narra de manera muy sensible a través de su protagonista la estrecha relación de una joven con la salsa y la manera de estar en el mundo desde la elaboración de una ciudad inmersa en la sonoridad salsera; precisamente, la ciudad de Cali en el occidente colombiano. Podría decirse que ella está totalmente eclipsada con la música, y su vida entera empieza a enmarañarse en una experiencia de escucha y goce, potenciada por el movimiento nocturno de la gran urbe y la cotidianidad musical de una ciudad siempre veraniega y fiestera. La desconexión de tal estesis musical, dilatada e ininterrumpida, solo se lograría en la tragedia. La novela se presenta como el auto relato de la protagonista María del Carmen Huerta. Al final se observa su firma y las fechas del periodo que comprende su vivencia más vehemente con la música. Este personaje puede considerarse una fotografía de la juventud colombiana que a través del disfrute de la salsa buscaba su realización emocional, corporal y social. Rumbear antes que todo, escapar del establecimiento institucional que solo ejercía control y vigilancia, escapar del estado de alarma permanente que implantaban los entes de autoridad y defensa de los ciudadanos, escapar del miedo perpetuo que instauraban narcotraficantes, guerrillas, bandas delincuenciales, paramilitares y fuerza pública a través de la violencia urbana de los años setenta y ochenta en Colombia, escapar a todo eso y -en términos estrictos- vivir.

En el siguiente fragmento de la obra la narradora y protagonista de la novela, María del Carmen Huerta, relata su visión de Mariángela; otra adolescente que fue su antecesora y «maestra» en los menesteres de la fiesta juvenil de la ciudad. Mariángela era admirada, respetada y venerada por el poder que ostentaba en los escenarios salseros de Cali; era la encarnación misma de la felicidad que perseguía la juventud emancipada de aquella época.

discursos hipócritas del entorno: permite asomarse a una realidad que es negada sistemáticamente por los discursos dominantes, permitiendo a los jóvenes cubanos que la practican instalarse públicamente en un nivel de coherencia o realidad que no puede ser expuesta públicamente con otros medios» (López-Cano 2007a, 56).

${ }^{91}$ La novela fue publicada en el año de 1977, el mismo día en que se suicidó el joven autor caleño a sus 25 años de edad. En Colombia, Qué Viva la música, se convirtió en un ícono de juventudes y proporcionó una ola de identificaciones desde el relato del autor a través de su protagonista. Ella retrata la rumba juvenil en la gran ciudad circundada de los deseos y esperanzas de sus jóvenes en medio del caos, del descontrol, el consumo de drogas y la descomposición social. 
Ante el espejo separé este pelo mío en dos grandes guedejas y abrí los ojos hasta que no se me vieron párpados y la frente se me llenó de brillantez y de hoyuelos los pómulos. También me dicen: "qué ojos", y yo los cierro un segundo, discreta. Si ya los tengo hundidos es porque en esa época lo deseaba: sí, tenerlos como Mariángela, una pelada que ahora está muerta. Quería yo tener ese filo que tenía ella cuando miraba de medio costado, en las noches en que bailaba sola y nadie que se le acercara, quién con esa furia que se le iba metiendo hasta que ya no era ella la que seguía la música: yo la llegué a ver totalmente desgonzada, con los ojos idos, pero con una fuerza en el vientre que la sacudía. Era la furia que tenía adentro la que respondía al ritmo. (Caicedo 1977, 13)

El fragmento anota la manera en que María del Carmen se arregla para salir de rumba. Tal cual lo hiciera cualquier adolescente, el ceremonial de preparación es un protocolo que incluye el ornato del cuerpo, la verificación del nuevo cuerpo que se dispone a marchar a la fiesta, la satisfacción del personaje y todos los pensamientos, ideas y anhelos, que se van cruzando en el proceso. Se requiere esta red ritual que impregnará el momento estésico de la danza en el lugar destinado. Pero hay un segundo factor de singular importancia en este relato y es la visión del «otro», que se ha construido en la urdimbre social específica de la fiesta salsera. Así como se habría elaborado ya en esa urdimbre una imagen de María del Carmen, ella describe con precisión la de Mariángela; ícono de identificación primordial para María del Carmen, a quien dota de unas propiedades singulares y únicas de belleza física, habilidad dancística, conocimiento del género musical, desenvoltura y fama. Judith Butler en su revisión de la sexualidad heteronormativa hace hincapié en la identificación, y su definición se ciñe acertadamente al sentimiento de la protagonista:

La identificación no se emplea como una actividad imitativa, mediante la cual un ser consciente se modela a imagen y semejanza de otro; por el contrario, la identificación es la pasión por la semejanza, mediante la cual emerge primariamente el yo (Butler [1993] 2002, 35).

Mariángela era la encarnación de la felicidad que perseguía María del Carmen, representada en la libertad de rumbear y vivir la vida tan desbordadamente como se pudo vivir en la rumba nocturna de los años setenta en Cali. Surge aquí una pregunta inexorable, quizás perturbadora o inquietante, pero que en la adolescencia o en la juventud temprana se vuelve obstinada en la búsqueda de respuestas; la del sentido de la vida: «Qué tal vivir sólo de noche, oh, la hora del crepúsculo, con los nueve colores y 
los molinos. Si la gente trabajara de noche, porque si no, no queda más destino que la rumba» (Caicedo 1977, 17-18). En un periodo relativamente corto la adolescente transformó su manera de vivir, acotada dentro de los cánones de comodidad de la vida burguesa y familiar de los sectores acomodados de la ciudad. En esa adolescencia se dejó impregnar totalmente por la música; la vida solo podía girar en torno a las relaciones que se constituían por la escucha, la fiesta, el baile, los amigos, y la diversión en la vida salsera. María del Carmen reinventó una manera de estar en el mundo; tenía que reinventarse a sí misma y configuró así un universo que dotó de sentido su existencia. Este universo gira en torno al cuerpo mismo; es el cuerpo que, en conexión con el sonido, siente, reflexiona y actúa. El siguiente fragmento resume, grosso modo, la fuerza del ritmo salsero que en conjugación con el cuerpo acude a dicha elaboración:

Sobreexpuse (uso el término porque mi papá es fotógrafo) a las montañas, los pelos de la montaña y el azul cielo. ¿Azul porque sobre exponía o porque de veras mejoraba el día? No, era la aridez y la congoja más terrible después de un año completo que no llovía sobre esta tierra buena. "A mí no me importa”, me decían, "si la veo a usted, con ese pelo, me refresco”. Y yo agachaba la cabeza, complacida. Pero también decían: “¿caerá la peste sobre la ciudad esta?”, y otro que contestó: “que caiga”, y se lanzó a bailar, frenético, chiquito, y yo también bailé, contagiada, y era la segunda que mejor bailaba (siempre fue Mariángela la primera) y no recuerdo que alguien haya dicho nada más, los que sabían inglés repetían la letra, prendieron las mejores luces y no hubo más pensamientos tristes sino puro frenetismo, como dicen (Caicedo 1977, 16-17).

La vivencia visceral del baile salsero que relatan mis informantes se confirma en la elaboración narrativa que hace Caicedo. Cuando María habla acerca de bailar «hasta el cansancio» o Esperanza afirma «es como transportarme» (2015, comunicación personal), o Ricardo indica «me disparé a bailar que hasta mi madre se aterró» (2015, comunicación personal), somos conscientes del cambio que se opera en el cuerpo y en lo que lo rodea. Dicho cambio consiste en transmutar la realidad a otro estado: es un estado de «goce», en palabras de los salseros, tanto interior como exterior. El frenetismo del baile tacha literalmente otros significados que acuden también en la escucha cuando no se baila. Por ejemplo, el significado de las letras; es decir, la realidad elaborada en las líricas salseras, las cuales abordan, por cierto, un extenso abanico de conmociones humanas. María del Carmen, en la novela de Caicedo, y mis entrevistados se encuentran en el vivir la experiencia corporal del baile, donde se empieza a comprender la transfiguración del «yo» en «otro». 
En la misma línea de la elaboración de la felicidad en el ritmo salsero sale a relucir un punto tan interesante como contradictorio. La mayoría de mis entrevistados al referirse a la alegría de la salsa normalmente tienen presente la tristeza que podría contener. A la idea de la felicidad intrínseca del ritmo oponen ese contrapeso: «Uno es el producto de la música que escucha. Es festivo y alegre porque la salsa es eso. Pero también es melancólica» (Sánchez 2014, comunicación personal). Sin embargo, la salsa es para ellos categóricamente alegre. En el testimonio de Quique se resalta: «Es festivo y alegre porque la salsa es eso». Además los salseros plantean la realización de la felicidad en la socialización: «Pues qué siento cuando escucho o bailo salsa... es algo más bien indescriptible; pero es alegría, pasión, amor, gusto, gozo, se vive la fraternidad con los amigos... Resumiendo es felicidad...» (Pérez 2014, comunicación personal). Daniel sugiere la misma definición: «La salsa es alegre; por más triste que sea, el ritmo es alegre» (Díaz Lepiry 2014, comunicación personal). Cosa contraria ocurre con el tango que, sin ser competencia de esta tesis, salió a relucir entre las otras músicas que se escuchaban y se bailaban. Entonces, el tango es categóricamente triste, melancólico y desgarrador, aunque místico y sensual a la vez. Así la emocionalidad de la tristeza puede estar presente, pero los escuchas logran desconfigurarla por completo a través de los múltiples códigos que posee el género. ${ }^{92}$

A la luz de estos precedentes podemos ver que el vertiginoso trayecto narrativo en la obra de Caicedo, refleja fehacientemente los mecanismos de la experiencia estética y de reconfiguración de identidades sociales en las personas que tienen una vivencia de la música, tan profunda y visceral como la protagonista de la historia y los personajes circunstanciales que la acompañan. Sumados los testimonios de mis informantes, a retomar en subcapítulos posteriores, y el significado primario que se ha sedimentado sobre la salsa, acudimos a la naturalización del género en la alegría. Ese significado primario que ya ha sido establecido en los oyentes salseros es la resultante de un hábito interpretativo. López-Cano, basado en los postulados de la semiótica de Peirce, lo conceptualiza en los siguientes términos:

\footnotetext{
${ }^{92}$ Vila (1996) argumenta que «Los múltiples códigos que operan en un evento musical (algunos de ellos no estrictamente musicales: códigos teatrales, de danza, lingüísticos, etc.) explicarían la importancia y complejidad de la música como interpeladora de identidades, y esto es algo que la distinguiría de otras manifestaciones de cultura popular de carácter menos polisémico. A su vez, como el sonido en sí mismo es un sistema de estratos múltiples, los códigos estrictamente musicales también son variados (Middleton 1990: 173). De ahí la posibilidad que tiene un mismo tipo de música de interpelar a actores sociales muy distintos, sobre todo si tenemos en cuenta que dichos códigos, lejos de reforzarse el uno al otro, muchas veces pueden ser altamente contradictorios». El texto citado por Vila es: Middleton, Richard. Studing Popular Music. Milton Keynes: Open University Press, 1990.
} 
Peirce no descartaba la generación de hábitos interpretativos. La red sígnica se puede clausurar por medio de un interpretante lógico-final, es decir, "la hipótesis interpretativa bien fundada que marca un punto de no retorno para la reflexión intelectual, un hábito interpretativo que bloquea temporalmente el proceso potencialmente infinito de la semiosis ilimitada (o fuga de interpretantes)” (Volli 2000: $31)^{93}$. La semiología estructural translingüística llama a este hábito código y lo considera una institución social por medio de la cual los fenómenos adquieren sentido en el seno de una comunidad (López Cano 2013a, 43).

A partir de dicho código significante los melómanos han elaborado un mundo de sentido en la felicidad del sonido salsero. El asociar la salsa a la felicidad es una práctica común de pensamiento y se ha afincado en el seno de la sociedad colombiana. Por lo tanto, el primer significado emocional que se ha estabilizado con el género es la alegría.

\subsection{Rumba y libertad en la escena salsera bogotana}

Los lugares de la escena salsera bogotana fueron vitales en el establecimiento de las relaciones de los jóvenes salseros con la ciudad. Las interacciones socioculturales que comportaron la discoteca, la salsoteca o la taberna, hicieron de éstas un acontecimiento. Interacciones que ocurrieron también en el antes y el después de la rumba juvenil. Los lugares fueron a la vez lugar, tiempo, evento, circunstancia, coincidencia e historia. Para los migrantes, por ejemplo los cientos de jóvenes que iban a estudiar a las universidades capitalinas, la salsa fue «una forma de sentirse acompañados en una ciudad extraña» (Arteaga 1990, 134). Al lado de la rutina o la monotonía de las clases y los extenuantes trabajos académicos, interacciones sociales como reunirse con los compañeros y amigos, asistir a la taberna o a la discoteca y desfogarse en la danza, se convirtieron en sentido para equilibrar las cargas de una vida lejos de casa y de la comodidad familiar. Para el joven bogotano, justamente, fue el escape a esa institucionalidad arbitraria y la oportunidad de conocer el mundo a través del otro, de conocer la ciudad, de conocer la noche y los mundillos que no se aprecian a la luz del día.

\footnotetext{
${ }^{93}$ El texto citado por López-Cano es: Volli, Ugo. Manuale di Semiotica. Roma: GLF, 2000.
} 
Por un lado, tales lugares contribuyeron a que el joven salsero construyera el sentido de una vida urbana en Bogotá; por otro, a la construcción de un mundo de sentido en el baile. Arteaga (1990, 19), sobre una experiencia propia en su libro La Salsa, relata lo siguiente sobre las tabernas: ${ }^{94}$

Nosotros pensábamos a veces lo mismo. Si la música vale la pena, también vale la pena ir a donde ésta resuena. Y nada nos lo impide. Tomamos la buseta que da mil vueltas y soportamos el trancón de turno hasta llegar allá. Nos emborrachamos, bailamos y salimos con una sonrisa de oreja a oreja para volver al día siguiente. Repetimos el viaje y ya somos clientes asiduos. Estamos enfermos de rumba, trasnocho, música y licor, pero no nos queremos curar.

Las tabernas tienen ese atractivo. Nos envuelven, nos atrapan y no nos sueltan. Tienen muchas historias que contar para dejarnos ir libremente. Y además nosotros hacemos parte de esas historias, como hacen también parte la esquina, la calle, el barrio, la ciudad y la música, toda la música que conforma nuestra memoria y que se desliza por los rincones de una taberna. Este libro está pensado en tiempo de taberna, en tiempo de noche y de rumba. [...]

Los relatos sobre la vivencia visceral de la salsa desde el disfrute del baile en la taberna o cualesquiera fuesen los escenarios urbanos en que se materializaba su práctica, permiten comprender aspectos de primer orden en la conformación de las relaciones subjetividad - experiencia estética y subjetividad - experiencia social que circunscriben la modelación de la libertad dentro de la escena salsera. Podrían determinarse cuatro factores de la experiencia de la taberna que materializaron esta modelación en la juventud salsera bogotana: el ejercicio de la libertad individual en la vivencia de la taberna, la ritualización de la felicidad en el baile, la personificación del lugar y la vivencia de las calles de la ciudad.

\section{Uno. Salsa, taberna y ejercicio de la libertad individual. Giro en la funcionalidad}

de la taberna. Los lugares de la salsa, tabernas, salsotecas y discotecas han estado orientados siempre hacia el goce de la rumba nocturna, cuya síntesis primordial es el

\footnotetext{
94 Con el ánimo de complementar lo dicho sobre las tabernas en la introducción de este texto, es importante anotar que las tabernas fueron sitios de la ciudad en los que se cultivó determinado tipo de disfrute con la salsa. A diferencia de la discoteca cuyo objetivo era el desfogue frenético en el baile, o sea la rumba por excelencia, en la taberna bogotana se cultivó una clase de escucha más reflexiva, por decirlo de alguna forma. Algunos se arriesgan a decir que era un tipo de rumba más intelectualizada, debido al corte académico, artístico o de izquierda de la gente que las frecuentaba. Entre finales de los años setenta y la década del ochenta, la noche bogotana quedó invadida por la dinámica que gestaba la taberna; también conocida como salsoteca.
} 
baile y la socialización alrededor de su práctica; el salsero iba a bailar y a compartir y cumplía con el cometido de la rumba. Sin embargo, en Bogotá a finales de los años setenta algunas tabernas salseras dieron un giro en su funcionalidad. Estimularon la práctica de la escucha y motivaron un conocimiento más en profundidad sobre la historia del mundo caribeño y la problemática del colectivo neoyorquino migrante que se reflejó en la música. Así, empezaron a ser frecuentadas por universitarios, intelectuales y gente de la izquierda capitalina. Paralelamente, continuaron las típicas discotecas o salsotecas a merced de la rumba febril de la juventud de la década del setenta y del ochenta. Entonces, se generaron otras tendencias de local que paulatinamente, incluso, se especializarán en diversos tipos de salsa, de eventos o de oyentes. $^{95}$ Aunque esto no quiere decir que el baile pasara a segundo plano: simplemente se reinventó su práctica y el estilo de la taberna activó otros modos de sentir y de apropiar el universo musical latinoamericano.

Cuando se crea el Goce Pagano (GP) el público empieza a cambiar. El GP ${ }^{96}$ rompe con un esquema. Porque eran todos los intelectuales izquierdosos, que lo que querían era otra vaina, que no querían luces, ni espejos, ni nada, solamente velas en la mesa y una música, así fuera con mal sonido, pero la música nuestra, a oír las noches y a gozarnos esa vaina y sin pretensiones de ser bailarín, o si quiero bailar sola, bailo sola y nadie me dice nada, ni me friega la vida, ¡me respetan! Empezaron a ir mujeres solas, grandes industriales, grandes intelectuales, y todo el mundo se empezó a reunir allí. Unos se iban al GP, otros al Quiebracanto, y después cuando nace el Café del Libro: allí, el público empieza a cambiar. Es la cultura, compartir cultura en torno a la música. [...] Sitios hechos a "lo universitario", a "lo intelectual", entonces todo el tiempo iba uno

\footnotetext{
${ }^{95}$ Por ejemplo, la escucha en los encuentros de melómanos o de coleccionistas. Cuando el coleccionismo tomó forma en la capital y se convirtió en la institución que es actualmente, se generó otro tipo de espacio; casual, que también invoca una práctica de escucha determinada; por cierto, bastante especializada. En los encuentros de coleccionistas prima el saber histórico, el musical y el de los intérpretes, de tal forma que, tácita o abiertamente, se fundan en competiciones que instituyen una política del conocimiento.

${ }^{96}$ En términos de Arteaga, «El carácter cultural del Goce lo convirtió en una especie de antidiscoteca. La informalidad y la clientela lo hicieron denominarse Salsoteca, un término que se definía por sí mismo. Nacieron entonces otros sitios similares como Quiebracanto, que fue fundado por Álvaro Monsalva con pretensión de dar cabida a la nueva trova cubana. Surgieron también La Teja Corrida, Café y Libro, Saoco, Hispanoamérica o El Son de los Grillos, Bogotá se poblaba de salsotecas y hasta el propio Villegas decidió poner fin a la sociedad y fundar su propio sitio al otro extremo de la ciudad» (1990, 165).
} 
viendo público universitario. De hecho el GP de la quinta, terminó siendo un enclave de universitarios (Carreño 2014, comunicación personal). ${ }^{97}$

Este tipo de sitios incubó unos nuevos modelos de vivenciar el cuerpo en el sonido y el intercambio social; lo que evidencia un giro en la práctica de la escucha y del disfrute de la música. En este giro rumbero repunta una experiencia estética más autónoma; más individualizada, puesto que el sitio no dispuso un ambiente en el que el oyente estuviera obligado a seguir el protocolo que orientaba las maneras sociales del baile o cuyo único objetivo fuera la rumba desenfrenada; es decir, no engendraba una práctica salsera obligatoria establecida por los usos tradicionales de la escena rumbera nocturna. Por el contrario, eran las personas que acudían a las tabernas quienes empezaban a impregnar el sitio con sus propios significados, a hacerlo suyo a su manera, lejos de las rutinas de rigor que imponían funciones determinadas en los lugares de rumba. De todas formas, en las tabernas que se extinguieron, en las que aún se conservan y en las que hoy en día constituyen parte de la escena salsera bogotana, las diversas prácticas son la consagración de la libertad.

Dos. Rumba, cuerpos dominados y liberados, el encuentro con felicidad. Como mencionaba al inicio del capítulo, en los escenarios donde se desataba la rumba se dispuso el rito de la felicidad, en el cual el cuerpo es el eje de la experiencia estética. El movimiento enardecido del cuerpo dominado pero al mismo tiempo liberado por el ritmo y la «melodía», convirtieron la salsa en una guarida donde desbordaron subjetividades bajo el amparo de que todo estaba bien por fin o de que lo estaría. No suene extraño presentar la dicotomía dominación-libertad como caras de la misma moneda. Aunque en apariencia no pueda existir un ente que al mismo tiempo sea dominado y liberado por la misma fuerza, la sonoridad salsera sintetiza dicha dualidad. Cuando el oyente escucha un tema de salsa su cuerpo es inmediatamente sometido por el ritmo, con la consecuencia de una respuesta corporal rítmica instantánea. El oyente

\footnotetext{
${ }^{97}$ También la prensa de la ciudad de Bogotá exalta el carácter distintamente especial del Goce Pagano y de los muchos otros locales que han sido dirigidos por César «Pagano» Villegas. Sobre Pagano y su aporte a la melomanía salsera bogotana, la revista Semana resalta lo siguiente: «No hay lugar en la casa de César Pagano que esté destinado a otra cosa que a la música. Desde muy joven se dedicó a coleccionar discos de Los Gaiteros de San Jacinto, Lucho Bermúdez y la Sonora Matancera, entre otro centenar de artistas. Con su enorme colección alimentó, hasta el año pasado, su templo de la salsa, Salomé Pagana, donde redefinió la rumba bogotana.

Allí le rindió un homenaje a Miguel de Cervantes, quien sentenció que "donde hay música no puede haber cosa mala”. Sus piezas no solo despertaron la admiración de los melómanos, sino también el goce de los bailadores, quienes pasaban sus noches entre marimbas, gaitas y salsa dura» (Sección Cultura 2015s.p.). (El artículo presenta como autor la Sección «Cultura» de la revista.
} 
no se pregunta, no vacila, no conceptualiza; simplemente, pre-lingüística y prelógicamente su cuerpo opera y actúa bajo la sonoridad de la música que está escuchando. Detenerse ante la mecánica sonido-respuesta corporal o, en términos más prácticos, interrumpir el movimiento, requiere una operatoria mental que implica un llamado categórico de voluntad por parte del oyente; llamado que quiebra el «orden natural» de la escucha; que perturba y cuesta:

Un movimiento se aprende cuando el cuerpo lo ha comprendido, eso es, cuando lo ha incorporado a su «mundo», y mover su cuerpo es apuntar a través del mismo, hacia las cosas, es dejarle que responda a la solicitación que estas ejercen en él sin representación ninguna. La motricidad, pues, no es como una criada de la consciencia, que transportaría el cuerpo a aquel punto del espacio que primero nos habríamos representado. Para poder mover nuestro cuerpo hacia un objeto, se precisa, primero, que el objeto exista para él, es preciso, pues, que nuestro cuerpo no pertenezca a la región del «en-sí» (Merleau-Ponty [1945] 1993, 156).

No obstante, la corporalidad que responde al sonido se consuma a la vez en liberación: el cuerpo libre que expone el gesto de la risa o la sonrisa como primer indicador de alegría antes de comenzar el baile. Pese a que hay unos pasos básicos a los que el bailador acude y que ya están naturalizados ${ }^{98}$ en la corporeidad del rumbero bogotano, y colombiano en general, ${ }^{99}$ el salsero se libera en cada movimiento. Improvisa individualmente y a veces involucra a su pareja en la improvisación; suelta a su pareja y la recobra, se aparta o se acerca; también baila sin pareja ${ }^{100}$ e impregna cada paso con

\footnotetext{
${ }^{98}$ En el baile salsero puede hablarse de una canónica del movimiento de caderas y de la independización de la columna baja del resto del cuerpo. La experta en danza y profesora universitaria Luz Stella Ramírez (2016, comunicación personal) explica: «Cuando bailas salsa mueves la zona baja, es decir el sacro y las rodillas van relajadas para poder mover la cadera en cualquier dirección dependiendo del ritmo».

${ }^{99}$ Es necesaria la aclaración de la naturalización de los movimientos corporales salseros en los escuchas colombianos y, evidentemente, caribeños o de otras latitudes latinas; pues europeos, estadounidenses o asiáticos interesados en bailar salsa deben acceder a clases metódicas y secuenciales en las cuales aprenden a bailar paso por paso y movimiento por movimiento. A veces incluso les enseñan a identificar y contar los tiempos del compás, hasta conseguir un gesto más o menos parecido al salsero «innato» que es el latino. Algo semejante ocurre con el músico intérprete no latino, pues leer la partitura «a la perfección» es justamente el motivo de no poder ajustar la dinámica de las medidas musicales al estilo. Tocar y cantar salsa implica, grosso modo, adelantarse en medidas microdimensionales a los pulsos y acentos exactos de la música. En palabras de algunos expertos, la salsa está mal escrita, en palabras del escucha latino, ésa es una de las partes que constituyen el «sabor» de la salsa. La especialidad de la medida temporal está fundamentada en la clave; célula rítmica, fundamento del son y por ende, de la salsa. En el epígrafe 2.5 copio una transcripción de la clave dos/tres y de la clave tres/dos.

${ }^{100}$ En los sitios públicos la usanza era el baile en pareja, costumbre que aún se conserva. Pero en Bogotá se puede apreciar en la misma magnitud el baile individual y, cada vez más, el baile con personas del mismo sexo.
} 
un sello personal e identificatorio, de tal forma que en la danza se va constituyendo la transfiguración del yo que lo llevará a rendirse ante la felicidad.

Ivan Gallo (2014, s.p.), articulista de Las dos orillas, sugiere una interesante evocación del asentamiento de la rumba bogotana en las siguientes palabras: «Las constantes visitas de Héctor Lavoe a la ciudad, el concierto de la Fania en la cárcel modelo en 1980, la apertura del Goce Pagano, Café Libro y Keops, convirtieron a la ciudad de la tristeza en la de la furia africana». En consecuencia, la escena rumbera capitalina era -y todavía lo es- un instrumento para cambiar el estado de ánimo y para subvertir la realidad. El dolor y la adversidad no se viven al ritmo de la salsa, sino que la salsa agencia otro estado emocional y otro estado de la realidad. Así, la rumba define el encuentro con la felicidad y nos encontramos ante una construcción imperativa de sentido: Todo está bien o lo estará.

Tres. La personificación del lugar. Luego, al contar la experiencia, el lugar puede ser personificado de tal forma que, más que su historia, tenga una biografía. El nacimiento de El goce pagano de César Villegas a finales de 1978 es icónico en la capital. El goce pagano rompió los esquemas de los locales bailables donde lo único que interesaba era la rumba. La manera en que se ornamentó el local y la música cubana que imperó en el sitio, atrajeron la atención de una serie de artistas, académicos y universitarios que, como manifiesta José Arteaga (1990, 164), encontraron en la salsa un discurso que contenía «cosas tan o más revolucionarias que las que ellos esbozaban». El vuelco hacia Cuba, su historia y sus conflictos, promovió el estudio de la cultura caribeña y latinoamericana en general $\mathrm{y}$, en el mismo grado de interés, atizó el fuego antiimperialista que fue pensamiento y posición política en la región. Bajo este precepto, El goce pagano se instauró como sitio cultural que rompió con la tradición bailable y empezó a gestar dinámicas de corte intelectual. Una muestra muy consensuada de lo anterior fueron los famosos «Papeles del Goce». Éstos eran todos los libros prohibidos en Colombia, que Gustavo Bustamante traducía. Entonces, se fotocopiaban y se hacían circular entre los asistentes del lugar.

Por añadidura, las propias historias del oyente generadas en tales espacios de felicidad, producen sentido de pertenencia hacia los mismos. En El goce pagano la gente elaboró una manera de estar y vivir que redunda en la libertad de ser como se quiere ser en ese momento. De esta forma, la escena salsera bogotana posibilitó el ejercicio de la libertad 
en la rumba tradicional, de descarga frenética corporal, y el ejercicio de la libertad en la rumba intelectualizada del Goce Pagano o de Quiebracanto. Reforzando el argumento de Carreño citado anteriormente, el escritor José Arteaga, partícipe de los menesteres salseros en los años ochenta, narra el origen de El goce pagano y el aporte al giro rumbero en las siguientes palabras:

A ninguno le gustó la calle donde quedaba el local, pero no tenían otra alternativa. El apartamento donde vivían no soportaba una parranda más y seis meses de búsqueda incesante debían llegar a su fin, así fuera en un sector como aquel. [...]. Los antiguos dueños del local habían renunciado a él. Eran militantes políticos y creían que la música y su ideología jamás llegarían a estar de acuerdo. Aura María Puyana supo del abandono. Corrió a contarles lo sucedido a los tres socios, y éstos tras pensar en las presiones y observar el local, lo tomaron, no sin cierta suspicacia. [...]. La decoración no fue más que fotografías de músicos y un par de cuadros. Las mesas y sillas eran de madera rústica. La luz era tenue y la pintura aún estaba fresca. [...]. El primer día de diciembre de 1978, El Goce Pagano abrió sus puertas. La publicidad, hecha con tarjeticas de invitación y de boca en boca, llamó la atención de curiosos y conocidos. La rusticidad del sitio atrajo a los intelectuales e izquierdistas de la época. Estudiantes y profesores de la Universidad Nacional, teatreros, cinéfilos, poetas, pintores y escritores jóvenes, descubrieron que la Salsa podía decir cosas tan o más revolucionarias que las que ellos esbozaban. La vieja música cubana terminó por contagiarlos. Existía un cierto apego hacia todo lo que representaba Cuba, por diferentes razones, así algunas no fueran las más válidas (Arteaga 1990, 164).

Sin embargo, la mayoría de estos sitios, los primeros en aparecer, en marcar pauta o los que se volvieron tradicionales, han desaparecido; entonces sus nombres se han vuelto emblemáticos. Lo que ha contribuido a que surja el mito del lugar; el lugar como ícono, como símbolo de una tradición salsera en la ciudad.

Cuatro. Ciudad y materialización de la libertad. Igualmente, en el antes y el después de la taberna, hay un cuerpo que se configuró en las interacciones sociales que se gestaron entre los jóvenes bogotanos de los ochenta. ${ }^{101}$ Para quienes vivieron alrededor

\footnotetext{
${ }^{101}$ Es interesante anotar que para muchos jóvenes, algunos todavía escolares de últimos años, la salsa fue un encuentro fortuito, ya que decidieron salir a conocer la ciudad y sin pensarlo lo que encontraron en el centro o sur, fue precisamente, la salsa. Wilson cuenta lo siguiente: «En una salida del colegio, a los 1314 años, nos llevaron a la Plaza de Toros, pero yo me volé con unos amigos y fuimos a ver el centro [centro-oriente] de la ciudad. Ver esa cantidad de bares nos sorprendió muchísimo, y teníamos mucha curiosidad de ver la ciudad en la noche. A los 16, ya decidí ir a estos sitios con algunos amigos. Después,
} 
de la carrera quinta, quienes estudiaron en las universidades del sector o quienes simplemente iban hasta allí al encuentro con la salsa, esa calle fue la materialización de un estado de libertad, baile y disfrute que demarcó las relaciones con su cuerpo y con la ciudad. Todo lo que se experimentaba a nivel social era muy fuerte; sobre todo la libertad de los jóvenes que no se vivía en otra parte de la ciudad. Sobre la vida situada en ese momento y en ese lugar, uno de mis entrevistados, residente en las Torres del Parque, y estudiante de una Universidad del sector, afirma:

«Había un momento en el primer semestre de la Universidad en que, entre el martes y el jueves, siempre estábamos de fiesta. Cuando llegaba el viernes y el sábado ya descansábamos, porque además iba mucha gente. Pero era como un continuo vivir en "La Quinta”; vivir en la salsa. Las Torres del Parque fueron muy importantes ahí también, [...], y ahí es donde se movía, digamos, no sé, todo lo que quería uno como joven, que pasara: sexo, drogas y salsa, en este caso. [...] La salsa ya estaba ahí como un gusto. La Quinta explotó mucho más eso, fue mucho más, ya no era simplemente la salsa, era todo lo que se movía a nivel social, a nivel de los jóvenes; la libertad que se podía vivir ahí. Sí, como unos límites rotos que yo creo que, difícilmente, había en otra parte de la ciudad; por lo que yo viví, que no voy a comentar a fondo [Risas] (Hernández Buesa 2014, comunicación personal).

Cuerpo y ciudad se fusionaron en La Quinta, y se fusionaron en todos aquellos apéndices de la taberna constituidos por calle, noche, libertad y salsa. El recuerdo de los salseros de la Bogotá nocturna de los ochenta está impregnado de música y lugar, cuya asociación es inevitable en toda la construcción narrativa de la vivencia musical. En consonancia con esta descripción se destaca que la narración de esta clase de vivencia da por sentado un juego de intersubjetividades, donde la experiencia está situada y solo es posible con la participación del otro; pues el otro es parte de la referencia del contexto; y en este sentido, la descripción del evento tiene una tendencia fenomenológica; por lo cual se puede comprobar que:

Una de las consecuencias de las consideraciones precedentes es que las descripciones fenomenológicas en primera persona de experiencias musicales, a pesar de su apariencia puramente subjetiva, están 'siempre-ya' situadas espacio-temporalmente e inmersas en una "socialidad viva” (Husserl), inherente a toda experiencia humana, por más íntima

los lugares que frecuentaba siempre tenían un corte más intelectual» (Córdoba 2014, comunicación personal). 
que ella parezca. Si esto es así, la apertura primordial de la experiencia consciente subjetiva a la intersubjetividad justifica la utilización de métodos de tercera persona (Pelinski, 2005, s.p.).

Con estos testimonios, además, se evidencia esa conclusión inequívoca de que el bar salsero siempre estuvo conectado a las calles que lo rodeaban. Por lo tanto la calle, los alrededores del lugar, conformaron una potencial extensión del mismo y fungieron también como escenario. La vivencia se producía allí, mucho antes de entrar en el bar y después, cuando la rumba terminaba; entonces, era allí donde se concluía el rito, en la calle. Incluso hubo épocas en que la rumba era acogida en las calles mismas de los barrios de la ciudad, lo que convertía a la calle una extensión de la escena. ${ }^{102} 103$ Arteaga (1990, 133) agrega al respecto:

Tan solo los jóvenes, los estudiantes que asumen sus compromisos con mayor displicencia, se asemejan al verdadero espíritu del melómano. Ellos se apoderaron en algún momento de las calles de las rumbas de barrio que hoy ya no existen por temor a la delincuencia. Los estudiantes hoy en día frecuentan tabernas con una insistencia que ha hecho que estos lugares aparezcan en varios sitios de la ciudad. Es por ello que las modas sobreviven en esos lugares más allá de la radio y su payola.

Desde otra perspectiva, «Circuitos rumberos y territorios del goce», título del segundo capítulo de Salsa y cultura popular en Bogotá (Gómez S. y Jaramillo M. 2013), hace referencia al estatus que alcanzó el género a finales de los años setenta y parte de los ochenta en Colombia. Aquí se describen y se cartografían seis territorios que nacieron en el centro y sur para luego extenderse por el oriente, occidente y norte de la ciudad. Sobre las interacciones generadas en esa vivencia de la rumba, los autores observan:

\footnotetext{
${ }^{102}$ Los Matinés barriales, Cocacolas bailables, Agüelulos (nombre que se les daba en Cali), eran diversos tipos de fiesta popular, donde se llevaba a cabo la rumba. Normalmente, se tomaba un espacio de la calle o las discotecas disponían de un horario en el día, y los muchachos acudían a bailar y socializar en las tardes de sábados y domingos. Sobre el término Agüelulo, Arteaga $(1990,108)$ define: «El agüelulo toma su nombre de la bebida natural que era la única posibilidad de consumo de los jóvenes menores de 21 años en las discotecas de la ciudad. Estas discotecas lograron con lo agüelulos ganarse a un público que, aunque no significaba mucho económicamente, sí representaba una buena posibilidad publicitaria. Los agüelulos eran bailes públicos que los sitios de rumba organizaban los domingos en la tarde, de una a seis, y cuya entrada costaba tres pesos en los primeros años».

${ }^{103}$ Gómez y Jaramillo hacen alusión a las mezclas e hibridaciones poblacionales que habitaban esa escena, y advierten sobre la siguiente diferencia: «[...] las prácticas festivas se convierten en catalizadoras de las afirmaciones propias y diferentes, y de sus intercambios culturales. De esta manera, se constituyen sensibilidades en dos tipos de escenarios: la fiesta popular asociada con las verbenas y bazares, y la fiesta juvenil conectada a las cocacolas y matinés. Por lo tanto, el barrio es el territorio de mediación entre la cultura campesina y la cultura citadina, y el escenario donde surge, se asienta y se confronta lo popular ampliado, lo que viene del mundo rural y lo existente del mundo urbano» (2013, 38).
} 
[...] A partir de esta experiencia los salseros de Bogotá construyeron su particular mapa rumbero por medio de recorridos exploratorios al principio, el descubrimiento de nuevos lugares y luego con un saber incorporado al cuerpo, a través de trashumancias urbanas más especializadas que consolidaron la pasión por este género. En esa cartografía sensible se fueron identificando los ritmos más gozosos, los mejores bailarines, el mejor sonido, los mejores programadores, los lugares a los que iban las mujeres más bellas, los más “pesados” y los más elegantes de la rumba. Esta cartografía fue crucial, además, para crear zonas personales de despeje musical, como en el caso de muchos viejaguarderos o melómanos, o para saber dónde encontrar a los mejores coleccionistas de acetatos (Gómez S. y Jaramillo M. 2013, 88).

A raíz de los anteriores testimonios y análisis notamos que la salsa propició, a la vez, una manera de apropiarse de la ciudad. El motivo era la salsa; la excusa perfecta para salir al centro, bailar, conquistar, disfrutar con los otros, aprender, conocer personas de otras latitudes ${ }^{104}$ e integrar unas redes de afecto y diversión que hicieron de Bogotá una urbe más vivible. En esta conclusión no se puede obviar que la narrativa que se despliega en la descripción del fenómeno salsero siempre está impregnada del lugar. En ninguno de los testimonios se presenta la disociación entre la rumba o la vivencia social con el sitio de disfrute donde se desarrollaba. Ésta es una característica determinante de cómo se vivió la salsa en los ochenta en Bogotá. El vínculo ciudad-calles-tabernas es indisoluble, como si la relación entre el barrio y la música que describe el nacimiento de la salsa en El Barrio de Nueva York fuese un reflejo directo de lo que ahí sucedía. Y algunos eran conscientes del hecho. Por ejemplo, Víctor, músico y arreglista de salsa y otros géneros populares, asevera que esta música se apropió en los barrios populares porque, en términos generales, era la constitución del barrio la que hacía que confluyeran ciertos factores que interpelaban a sus habitantes:

Yo pienso que fue la atmósfera del barrio latino que el desarrollo fue en barrios como el Santafé, ${ }^{105}$ porque además era un barrio popular, un barrio latino. Es el mismo barrio

\footnotetext{
${ }^{104}$ En cuanto a conocer personas de otras partes, fue reiterada la remisión entre los universitarios de esa época, a aquellos estudiantes que iban de la Costa Atlántica a Bogotá. Víctor Ramírez cuenta que el Barrio Santafé donde pasó mucho tiempo de su juventud, gozaba de una amplia población barranquillera, y que era muy afecto a una familia costeña con la que, prácticamente, se crió. Este encuentro definió su conocimiento y predilección por la música del Caribe y la salsa. Además, en su calidad de músico, fue fundacional para su profesión.

${ }^{105}$ El barrio Santafé forma parte del centro tradicional de la ciudad. Es un sector histórico que en 1948 sufrió los estragos del bogotazo. Contiene sitios de valor histórico y cultural para los capitalinos y estaba en el circuito de rumba de los años ochenta. Con la problemática usual de las zonas de tolerancia, hoy
} 
donde camina Pedro Navaja, con basura con las calles rotas y las paredes desconchadas, algunos postes sin luz y perros, habitantes de la calle, o sea, es un barrio latino. Entonces, pues obviamente los arriendos eran baratos y era en el centro. Muchos de los músicos vivían allí. Yo no vivía allí pero trabajaba mucho tiempo allí, ensayaba allí todo el tiempo. Los domingos estaba metido allí en ese barrio, en la carrera 17 con 23, más o menos. Entonces, llegaban todos los músicos que vivían en el sector. Intercambiábamos ideas, charlas conocimientos, patrones, nos enseñábamos mutuamente (Ramírez 2014, comunicación personal).

En el desarrollo del subcapítulo se puede comprobar que la descripción de la experiencia, en primera persona, va constituyendo el índice fundamental de elementos que vinculan la red de sentido en torno a la vivencia de la salsa, pero con una localización determinada en la ciudad, y específicamente en la ciudad de Bogotá. Es fácilmente comprobable que, si bien la percepción es algo individual, en términos de Pelinski (2005, s.p.), la «subjetividad es capaz de abrirse a evidencias compartibles con el Otro». Desde la orientación neuro-fenomenológica que utiliza el autor, vale apegarse a la definición de «socialidad viva» que propone Edmund Husserl y que he citado anteriormente para hacer énfasis, precisamente, en que las descripciones de los informantes con toda la carga de subjetividad que posean, no están desvinculadas de la localización de la experiencia y en medio de su contexto social. De tal forma que experiencia, localización y socialidad deben entenderse como un continuum cuyo dinamismo y vitalidad hacen posible la re-creación, significación y narración de la vivencia

De esta forma, la materialización de la libertad en la juventud salsera bogotana de la década de los ochenta se yergue como una estructura de significado, de sentido, en la vida cotidiana de quienes la experimentaron. Las realidades que emergían gracias a la vivencia en la escena musical guiaron un sentir inmediato de la libertad que, cómo señalaba al principio, era una búsqueda constante tanto de los que habitaban la ciudad como de los que llegaban a estudiar temporalmente o a establecerse luego en definitiva.

presenta graves conflictos de prostitución, drogas, violencia callejera y los que comporta su alto movimiento comercial. 


\subsection{Universos sonoros en la intimidad de la escucha}

Para algunos oyentes el goce de la danza y la conciencia del cuerpo que ella establece como situación naturalizada ante la escucha, pueden hallarse lejos de la tradicional rumba nocturna bogotana en bares, tabernas, salsotecas o discotecas, normalmente los fines de semana. Lugares, tiempos y medios de escucha demarcados para esta actividad pierden importancia cuando se acude al goce de la música en la intimidad de la casa, en el encuentro con los amigos o en la escucha individualizada. La ubicuidad de la práctica de escucha musical, en términos de Palominos y González (2013, 6), se potencia actualmente, entre otras circunstancias, gracias al alcance relativamente sencillo de artefactos mediados por la industria. Los reproductores que llevan los coches, los dispositivos portátiles para reproducir formatos $\mathrm{mp} 3$ dispuestos en los teléfonos móviles, los discos compactos e incluso los típicos casetes (en los cuales se grababan los temas salseros preferidos que se escuchaban en el boom salsero y que algún oyente todavía conserva), favorecen las prácticas de escucha individualizada o desarticulada de la escena musical urbana.

Una interesante consecuencia de lo anterior es que los dispositivos portátiles han hecho posible que los migrantes lleven consigo su colección musical más personal e íntima a diversas regiones y países. En éstos el acervo cultural se manifiesta, se representa y se vivencia por medio del objeto y de su uso, de la habitualidad de su uso, favoreciendo la puesta en marcha de la cultura pero ahora en nuevos entresijos de hibridación. Ciertamente, en la salsa confluyeron tales prácticas, ya que los migrantes y las generaciones subsiguientes portaron en la medida de sus posibilidades los artefactos de su propia cultura; en otros términos, materializaron su cultura en el nuevo territorio. Para algunos analistas, la música fue de capital importancia y en torno a ella los nuevos pobladores se aferraron a una identidad que propendía por una estabilidad emocional en medio de un entorno de exclusión y hostilidad. A partir de estas circunstancias coyunturales, tales artefactos y hábitos que influyen o definen las prácticas culturales de la postmodernidad obligan a una nueva formulación de las metodologías de estudio de la cultura.

Al respecto, Timoty Rice comenta acerca de las formas de hacer etnografía hoy en día, las cuales empiezan a tener presente una localización movible del ejercicio musical, de sus intérpretes y de los investigadores y, por otra parte, de los mismos artefactos 
tecnológicos. Desde esta postura apoya la noción de movilidad espacio-temporal que caracteriza las prácticas musicales y, por ende, la investigación que se desprende de ellas, poniendo en la mira el potencial hibridatorio de las músicas al igual que los hábitos modernos de la escucha:

La mezcla de estilos culturales y musicales, en versiones ahora accesibles en cualquier parte del mundo, se ha hecho posible en primer lugar por el colonialismo y en segundo lugar por la ubicuidad de los medios electrónicos. La simultaneidad de todos los lugares en un lugar es otro marcador, además del viaje en el espacio-tiempo, de la modernidad en todo el mundo (Rice 2003, 94).

En efecto, gran parte del interés para elegir el tema de esta tesis sobrevino de observar cierta cantidad de migrantes colombianos radicados en Barcelona, Madrid y París que, justamente, vivenciaron la Bogotá salsera de los ochenta cuando eran estudiantes universitarios. Después, al viajar al exterior, porción muy importante de la valija viajera era la música. Acetatos y casetes, los más personales y esenciales para ellos, cruzaron el océano y tienen hoy un lugar privilegiado en la estantería de la casa. Otros han sido archivados en cajas debido a la falta de espacio; pero perviven allí sin desecharse todavía. Muchas de estas colecciones se ampliaron y se renovaron en la nueva ciudad y la música se reproduce ahora en viejos tocadiscos, caseteras o equipos de sonido más modernos. De esta forma, el sonido integra un circuito de la vida de estos salseros, que transcurre por la corporeidad, la subjetividad y la vivencia con el círculo social integrado por compatriotas, expatriados de otros lugares del mundo y los amigos lugareños y nacionales que residen en el país de acogida. Vale la pena reiterar aquí el postulado de Slobin «Todos somos culturas musicales individuales», puesto que nos encamina hacia esas formas postmodernas de vivencia musical y ayuda a explicar el universo sonoro que constituye a cada persona por separado.

Tales universos sonoros individuales han sido posibles ya que actualmente las nuevas tecnologías permiten operaciones muy especializadas a través de las cuales el oyente medio puede organizar de manera muy personal listas de canciones o piezas que se traspasan a medios digitales o se reproducen desde la Internet. Éstas han obrado diversos mecanismos para brindar agilidad y economía en los medios personalizados de disfrute musical, de manera que se potencia la escucha personalizada y se promueve la adopción o actualización de las nuevas formas de reproducción musical. 
En la Bogotá postmoderna, en muchos casos, acudir a la escena de la fiesta como ocurría hace dos o tres décadas ya no es factible por las contribuciones tecnológicas señaladas que acercan la música al oyente, por el trasvase generacional o porque factores de índole socio-comportamental en la movilidad nocturna de la ciudad agudizan la desmotivación para hacerlo. También conviene considerar que muchos salseros que disfrutaron de la rumba nocturna de la ciudad, sienten que los nuevos espacios de la escena ya no los convocan, debido a que la vida con todas las realizaciones que acarrea, como familia, hijos o trabajo, obligó a cambiar las prácticas de escucha habituales de aquella época por otras que se adaptaran a las nuevas condiciones. A propósito de esta tendencia hacia la intimidad tan individual, o en grupos más restringidos, que los oyentes logran gracias a las tecnologías de registro del sonido y además de la imagen, Cámara de Landa alude a Peter Manuel para indicar:

El video, de reciente difusión, permite el acceso a la ejecución por parte del intérprete favorito y contribuye a la atomización del auditorio, de manera que la cultura del living room reemplaza a la del café. Se pierde el sentido de participación y de catarsis colectiva (entramos en guetos domésticos alienados) La tecnología del cassette [sic], al ser barata, permitió a las industrias caseras -principalmente en el Tercer Mundoresponder a las expectativas locales y regionales, a la vez que ofreció la potencialidad para un control democrático de los objetivos de la producción musical y dio lugar a estilizaciones populares de músicas folklóricas (como en el jaipongan de Java) (Cámara de Landa 2004, 297). ${ }^{106}$

En efecto, el siglo XX acude a la mediación del sonido a escala masiva a través del registro y la reproducción del audio. ${ }^{107}$ El registro del sonido fue en principio acústico y las primeras grabaciones de Thomas Alba Edison en el fonógrafo datan de 1877; luego aparece la grabación eléctrica en 1887, cuando Emile Berliner patenta su gramófono; y, para completar el proceso que llevaría el sonido musical por todas partes, en 1900, se crean las matrices de cera reproducibles, «imprimiéndose un mismo disco en fábricas instaladas en diferentes ciudades y países» (González 2000). De esta forma, la posibilidad del copiado masivo y los procesos de circulación de la música grabada consumaron todo el aparato de escucha musical que rigió las demandas del consumo

\footnotetext{
${ }^{106}$ El texto citado por Cámara de Landa es: Manuel, Peter: Popular Musics of the Non·Western Wold. An Introductory Survey, New York/Oxford: Oxford University Press, 1988.

${ }^{107}$ En el artículo: El canto mediatizado: breve historia de la llegada del cantante a nuestra casa, Juan Pablo Gonzáles (2000) referencia brevemente el interesante recorrido de este proceso y muestra cómo se vislumbra y sobreviene el desarrollo a gran escala de la industria discográfica en el siglo XX.
} 
personal en la postmodernidad. La familia deja de asistir con tanta asiduidad a la sala de conciertos para concentrarse en torno al fonógrafo dispuesto en la sala de la casa. ${ }^{108}$ Sobre la incursión del fonógrafo en los entornos domésticos González $(2000,29)$ añade:

La entrada del invento al espacio doméstico venía siendo incentivada desde fines del siglo XIX mediante campañas publicitarias donde se presentaba la imagen de una familia extasiada frente al fonógrafo. Para entrar al salón burgués, este aparato de laboratorio debió convertirse en mueble, vistiéndose de maderas finas, ocultando el altavoz, y buscando diseños clásicos, como el de Luis XVI, o de moda, como el art deco. Algo similar ocurriría en la década de 1920 con la radio, según veremos más adelante.

La aparición del fonógrafo y del disco, sumada a las formas en que se adquiría y circulaba o viceversa, prefiguraron el poder adquisitivo, en primera instancia, de las elites burguesas. Así, la invención del disco fue el suceso más trascendental para la popularización de las músicas y la expansión de la escucha de determinados géneros en el siglo XX. Pero no me estoy refiriendo a una «escucha masificada» desde los supuestos de una escucha colectiva o comunitaria, sino al advenimiento de la escucha individualizada, personalizada, hecha a la medida del gusto y preferencias de un consumidor. Lo que se masifica es la producción y la adquisición de la música a través del disco. En pocos años la música grabada, en cualquier formato, se convirtió en el epicentro de una nueva estesis en el sonido. Antes del registro sonoro y la copia multiplicada exponencialmente, como es usual en estos tiempos, las personas acudían colectivamente al concierto. En tales prácticas la experiencia estética era diferente al estar mediada por la socialidad; la socialidad en público y, a veces, posiblemente fracturada por esta intervención. Por consiguiente, el ritual de escucha fue mutando,

\footnotetext{
${ }^{108}$ Para Jacques Attali (2001), el cambio de hábitos de escucha corresponde al modo en que se ha organizado la economía históricamente y al rol que ha desempeñado la música en este orden. Si en principio la música era un fundamento ritual, y su función era sacrificial, luego, es mero juego representacional. Con el advenimiento de la burguesía, no solo los príncipes deseaban para su corte una capilla musical. Había otros que compartían el mismo deseo, pero no podían darse el lujo de mantener músicos a tiempo completo; con lo cual, fue necesario empezar a comercializar las presentaciones. De esta forma se pudo cumplir, también, con toda la demanda de escucha que se imponía a finales de siglo: «Al final del siglo XIX, cuando la burguesía comenzó a consolidar su posición en la sociedad, no fue suficiente para la música ser confinada a los salones de conciertos -se hizo imposible dar acceso a la música a todos los que lo querían [...] al final del siglo XIX, fue necesario crear otra forma de organizar la música, con el fin de permitir a más gente acceder a esa música. Era momento de inventar el gramófono. El gramófono era necesario porque era imposible construir suficientes salas de concierto capaces de albergar los cientos de miles de personas que estaban en posición de comprar música. Había necesidad de crear un medio de tener un concierto privado, porque era la única manera de satisfacer a todos aquellos en posición económica de acceder a la música» (Attali 2001, 3).
} 
alimentado por las nuevas estructuras y elementos que permite y que precisa la intimidad.

Sin ir más lejos, se establece una relación de pertenencia de la música representada en la posesión del objeto: el artefacto que la contiene y que permite su reproducción incesante. La música ya no es tan efímera. Antes se disolvía en el tiempo y solo se recuperaba en la memoria hasta que hubiese otra ejecución. Ahora se disuelve también en el tiempo pero es posible su repetición tantas veces como sea deseada, sin tener que esperar hasta una nueva presentación pública. Frith, al observar las funciones de la música, indica que la música popular es algo que se posee. Aludiendo al caso de sus estudios sobre los fans del rock en Inglaterra y la cuestión del disco y la música que contiene convertidos en artefactos, afirma:

En realidad, la noción de propiedad musical no es exclusiva del rock, -en el cine de Hollywood se ha repetido hasta la saciedad la frase «están tocando nuestra canción»sino que revela algo reconocible para todos los amantes de la música; es un aspecto fundamental de la manera en que cada uno piensa y habla sobre "su" música (la radio británica tiene programas de todo tipo basados en las explicaciones de personas que cuentan por qué ciertas músicas les «pertenecen"). Obviamente es la característica de mercancía de la música la que permite articular ese sentido de posesión, pero uno no cree poseer únicamente ese disco en tanto que objeto: sentimos que poseemos la canción misma, la particular forma de interpretarla que contiene esa grabación, e incluso al intérprete que la ejecuta (Frith [1987] 2008, 426).

De hecho, en la salsa la percepción de posesión se extiende desde lo material de la música hasta, incluso, un intérprete, y es una posesión que adquiere visos sentimentales hacia él mismo, en ocasiones, paternalistas. El caso de Lavoe es piedra angular para entender la perspectiva de pertenencia del artefacto y del intérprete con sus poseedores. Cuando los salseros dejan la parte musical para adentrarse en la biográfica, el lenguaje aporta matices que revelan dicha relación, lo cual sucede con diversos cantantes y, quizás, se basa en las complicadas y trágicas vidas que tuvieron. Francisco Cantor, en la entrevista realizada en 2015, me enseñaba con entusiasmo la magnífica voz de uno de sus intérpretes cubanos más recordado: Panchito Riset. Por desgracia, Riset padecía una 
incurable enfermedad que le causó grandes y crónicas dolencias. ${ }^{109}$ Cuando Francisco narra esto, inevitablemente llora y es visible su tristeza (curiosamente me pidió disculpas por la eventualidad). Francisco, cuyos testimonios desarrollaré también posteriormente, experimenta una fuerte identificación con la música cubana y con el país caribeño, al extremo que se declara, a la vez, abierta y decididamente cubano. En concordancia con Frith, lo anterior refleja que «Al “poseer” una determinada música, la convertimos en una parte de nuestra propia identidad y la incorporamos a la percepción de nosotros mismos» $(1987,426)$.

La repetición de la música en la intimidad de la escucha anuncia el establecimiento de una corporeidad distinta en la estesis sonora; ese cuerpo vivido que era intervenido por la presencia del otro y por la norma que rige la conducta; ese cuerpo que se presentaba ante un otro ajeno o extraño o, por el contrario, un otro conocido, ahora ya no debe construirse en el sentido común que establece hegemónicamente el consenso social. La escucha individualizada libera la corporeidad del yugo sociocultural y sociocomportamental y da paso a nuevas formas de constitución de la subjetividad organizando universos distintos en cada oyente. Como anuncia Frith, la respuesta de la música a cuestiones de identidad es una de las funciones más notables. En la rumba de los ochenta el bailar salsa definía un tipo de socialidad en los jóvenes. Era imperiosa la necesidad de bailar, y de bailar bien; cada vez mejor, enriqueciendo la cantidad de pasos y perfeccionando el estilo del baile. Esto aseguraba que el colectivo que se encontraba en la escena se fijara más en las parejas de baile. A mayor destreza del bailador, mayor grado de aceptación en los y las jóvenes, lo que aumentaba significativamente las posibilidades de conquista del sexo opuesto. El no bailar salsa suponía una clara desventaja para cumplir este objetivo. ${ }^{110}$

Por lo tanto, tal tipo de socialidad implantaba también una obligación. Frith sostiene que «la producción de identidad es también una producción de no-identidad -es un proceso

\footnotetext{
${ }^{109}$ Panchito Riset fue el nombre artístico de Francisco Riset Rincón (La Habana 1911 - Nueva York 1988), una de las voces más importantes del bolero, aunque en sus comienzos interpretó también guarachas, cha cha chás y otros géneros cubanos. En 1981 perdió sus piernas debido a la diabetes.

${ }^{110}$ Los bailes usados con el propósito de socializar reúnen una cantidad de actitudes y posturas corporales que definen un marco comunicativo -no necesariamente lingüístico- y un marco de acción interpersonal. George Herbert Mead se interesó por el estudio de estos gestos y por cómo las personas, a través de patrones sociales y culturales, comprenden las intenciones de comportamiento que estos gestos sociales acarrean. Para Mead el carácter simbólico de los gestos es la clave de la interacción social. La obra de Mead se ha ido publicando fragmentariamente; sobre gesto y acción social ver «La Génesis del self y el control social» de 1925, traducción de Ignacio Sánchez de la Yncera (Mead [1925] 1991).
} 
de inclusión y de exclusión-» (Frith [1987] 2008, 422). Aunque se refiere a la inclusión de lo que gusta y la exclusión de lo que no, permite entender que la producción de identidad también está asociada con lo que las personas hacen y asumen sin querer a causa de un formulismo social. Para algunos jóvenes el bailar ante los demás y el sacar a bailar a alguien en público no era tan divertido. Era un convencionalismo que implicó una práctica exigida y reiterada, hasta que poco a poco se «dominaba la situación» y, aparentemente, la práctica se normalizaba. Si el joven no interactuaba desde este ejercicio, quedaba definitivamente excluido de los oficios de seducción que imperaban en la moda del momento. En la perspectiva de Alan P. Merriam ([1964] 1998, 291), dicha práctica obedecería a «la función de refuerzo de la conformidad a las normas sociales», en el sentido de que la aprobación del baile como convención social implicaría determinado control sobre los miembros de un grupo, ya que la convención establecía pautas de conducta en el entorno que promovían la organización social, tales como el tener más opciones de conseguir pareja o el ser presentado y reconocido en sociedad. Esto todavía puede ser así, pero en un nivel más moderado.

Por el contrario, algunos jóvenes, sobre todo jóvenes aprendices, se sentían mejor cuando se bailaba en casa; bien sea con los hermanos mayores u otros familiares, o bien sea solos. El factor de la privacidad llega a ser una variable significativa en la operación de la estesis, y acciones como elegir individualmente los temas musicales, escoger la hora y el lugar para practicar, asumir la actitud para escuchar y bailar y, en sí, investirse del rol que el bailador imaginaba y deseaba para proyectarse después en público, eran acciones que permitían la materialización de realidades en la intimidad de la escucha.

Otro factor fundamental en esta nueva estesis es la ausencia del intérprete mismo. Sin la presencia de su figura o de su imagen solo queda su voz; una voz que puede percibirse y sentirse más cerca. ¿Qué sucede entonces con el cuerpo que escucha y empieza a transitar por los códigos que entretejen esa voz, a descifrarlos? En un profundo análisis de las relaciones entre música, política y poder y de la economía de la música en sí, Jacques Attali (1977) señala cuatro redes de difusión de la música en consonancia con las estructuras y tecnologías de cada una de las sociedades que las produjo. Sobre la red que enmarca la grabación, a la cual denomina red de la repetición, observa:

Concebida como modo de conservación de la representación, esta tecnología, en cincuenta años, ha creado, con el disco, una red nueva de organización de la economía 
de la música. Cada espectador tiene una relación solitaria con un objeto material; el consumo de música se vuelve individual, simulacro del ritual sacrificial y espectáculo ciego. La red ya no es aquí una forma de sociabilidad, ocasión de encuentro y comunicación de los espectadores, sino instrumento de una accesibilidad formidable a un depósito individualizado de música. Ahí también, la nueva red aparece en la música como anuncio de una nueva etapa de organización del capitalismo, el de la producción en serie, repetitiva, de todas las relaciones sociales (Attali (1977) 1995, 52).

En efecto, el disco generó nuevas interacciones socioculturales en los modos de consecución, conservación, uso, colección y almacenamiento del mismo, convirtiéndose en uno de los artefactos culturales más importantes en las mediaciones culturales a lo largo del siglo e interviniendo y definiendo nuevos modelos de escucha.

A su vez, la llegada de la radio marcó la pauta en la formación del gusto musical de los públicos y en la estética de la música popular que los compositores empiezan a producir bajo las demandas de la industria cultural. Si el disfrute musical estuvo circunscrito a la escucha colectiva y anclado siempre a un referente visual ya que la gente asistía a las presentaciones en vivo, con el gramófono y la radio la experiencia se volvió un acto netamente auditivo. Indudablemente, el hecho de escuchar el sonido en ausencia física de los intérpretes, ante lo cual solamente se percibía su voz o sus ejecuciones instrumentales, debió suponer importantes cambios en la manera de constituirse la intimidad de la escucha y, en consecuencia, cambios en la estesis de este nuevo universo sonoro.

La radio se convirtió en el otro artefacto definitivo para la cultura del siglo XX, que llegó después del disco e incursionó en el mercado colombiano a finales de los años veinte. ${ }^{111}$ La radio hizo posible la distribución a gran escala de la música grabada, ${ }^{112}$

\footnotetext{
${ }^{111}$ Sin embargo, esta incursión no se hizo sobre la base de transmisiones colombianas sino extranjeras. Jaime Cortés $(2004,167)$ afirma: «Ante la ausencia de emisoras en Colombia durante los años veinte, el público dependía de las estaciones radiodifusoras de Cuba, México, Puerto Rico y especialmente de EE.UU. El acceso a la infraestructura desarrollada fuera del país determinaba las pocas transmisiones radiales de obras musicales colombianas y el contexto en que éstas se interpretaban. En algunos casos, algunos músicos colombianos se beneficiaron de los intersticios abiertos por otros músicos latinoamericanos en el medio estadounidense, con lo cual tuvieron la oportunidad de interpretar su obras en programas radiales».

${ }^{112}$ Sobre la industria musical en Latinoamérica, y en especial el florecimiento del tango-canción a mediados de la década del veinte, que se asentaría en Colombia desde la proyección que se le dio en Medellín, Santamaría-Delgado $(2014,129)$ señala que: «El impresionante crecimiento económico de Argentina durante ese periodo fue un factor crucial para la consolidación del género musical. El crecimiento de la clase media y la aparente solidez del mercado de consumo interno permitieron el
} 
con lo cual llegó a convertirse en uno de los principales referentes de escucha y de formación de gusto musical de nuevas audiencias. Con la siguiente particularidad:

La radiodifusión se desarrollaría según el concepto de emisión pública y recepción privada, creándose un nuevo tipo de público, que participaba simultáneamente de un evento sin estar en el mismo lugar. Este hecho elevó a dimensiones insospechadas la masificación y popularización de la música, que podía llegar a millones de auditores cómodamente instalados en la privacidad de su hogar. Al mismo tiempo, la diseminación de receptores por el mundo contribuyó a la circulación de repertorios locales, que ahora alcanzaban audiencias nacionales e internacionales, produciendo los consiguientes fenómenos de homogeneización y diversificación, paradojalmente en forma simultánea. (González 2000, 31).

Según Santamaría, durante la década de 1920 en el eje Caribe empezaron a circular sellos discográficos estadounidenses; es el caso de Columbia y RCA que aprovecharon, en primer lugar, el auge del tango y montaron en Argentina y Chile sus respectivos estudios de grabación y prensas disqueras (2014, 130). Sobre la circulación de productos culturales en la misma época en el circuito caribeño, Wade $(2002,17)$ indica que «Tanto en Colombia como en la mayor parte de América Latina, la música, desde los años 20 en adelante, fue capaz de transportar a la gente hacia Estados Unidos, Cuba, México y Argentina, y algo semejante puede decirse del cine»; haciendo referencia a que las músicas populares que se escuchaban en los medios provenían del extranjero e incluso de Europa. Por este motivo no es extraño el auge del bolero-canción y el son cubano, ya en las discotecas personales y familiares; primero en la costa caribe y después en el interior. Al parecer fue en la ciudad de Barranquilla donde se fundó la primera estación radial del país en 1929, llamada La Voz de Barranquilla. En este periplo musical extranjero por el eje Caribe, incluso intérpretes colombianos grabaron música cubana. De esta manera se observa que la circulación de músicas por la Cuenca del Caribe facilitó la escucha y promoción, entre otras, de la música cubana que empezó a sedimentar una memoria de la música caribe en el interior de Colombia desde la década de los veinte.

Por su parte, en 1963 la casa holandesa Philips lanzó al mercado el muy célebre casete, que acompañó la comercialización de vinilos entre los años setenta y mediados de los 
noventa, ya que su producción y venta tenían precios más reducidos en comparación con el disco y esto facilitó la expansión del mercado a sectores menos favorecidos económicamente. La masificación de las músicas populares se debe en gran parte a este artefacto, entre ellas la salsa en Colombia. Pero hay dos factores trascendentales en la aparición y función del casete, dirigidos a la autonomía del usuario en la selección de piezas musicales y el ordenamiento de las mismas a lo largo de la cinta magnética y, por otra parte, al copiado: Aquél que no se circunscribe en legislaciones y aquél que es ilegal. ${ }^{113}$ Era el oyente quien escogía los temas y los organizaba de una forma autónoma que obedecía a su gusto personal. Los temas eran grabados manualmente por medio de la reproducción de un disco o a través de la emisión radial. Sin embargo, el proceso era tan común que los usuarios no tenían conciencia de la posible ilegalidad en la que incurrían al copiar la música. A la radio se accedía gratuitamente y, por lo tanto, lo que en ella se transmitía, le pertenecía a todos. Además, aún no circulaban en los medios las políticas de derechos de autor de manera tan categórica como ocurre actualmente. Al mismo tiempo, la práctica de copiado empezó también a comercializarse en Bogotá y otras ciudades del país, y de esta forma se encontraban en la 19 casetes con el registro de un disco completo, o los usuarios hacían el encargo de sus listas particulares. Por lo que la célebre tarea permitió la conformación de un público más amplio y más conocedor y promovió la constitución de un gusto musical salsero a lo largo y ancho de la ciudad. En consecuencia, radio y copiado manual incentivaron ciertos hábitos de escucha que enriquecieron el archivo de una memoria personal y colectiva de la música caribeña.

Pese a todo, fue también la construcción del Caribe desde la sonoridad de su música; una memoria desde el imaginario del mundo caribeño motivado por la radio y los discos de vinilo. Melodías, armonías, timbres, ritmos y letras, re-creaban para las audiencias la vida cubana. Bogotá y Colombia forjaron, gracias a la escucha de la música caribeña y la elaboración de sus líricas, una imagen exaltada de Cuba; una elaboración de su universo idealizado, puesto que las audiencias, en su mayoría, nunca han pisado ni conocido realmente el país caribeño. El son alberga las historias del pueblo cubano, con

\footnotetext{
${ }^{113}$ Attali $(2001,4)$ hace la siguiente observación: «... debemos diferenciar entre tres tipos de copia. Si copio algo para mi uso personal, no es ilegal. Segundo, si copio algo para regalar a otra persona, tampoco es ilegal, y este derecho se mantiene para cualquier número de formatos como cds, cassetes o dvd. Llamativamente, existe legislación que intenta hacer ilegal, por primera vez en la historia, hacer el mencionado regalo por internet...lo que significa que no va a funcionar. El tercer tipo de copia, a saber, la duplicación masiva para venta o lucro es claramente ilegal».
} 
las cuales honra esa «cierta manera» en que se vive y se siente en la isla. La escucha del son aquí en Colombia reivindicó tácitamente un universo caribeño expuesto a la invasión o el bloqueo internacional; reivindicó la revolución. Aquel sonido de Cuba protagonista en las tabernas bogotanas transfirió el ideario revolucionario que, aunque no está explícito en las liricas soneras, se tradujo como tal en la escucha de los públicos bogotanos. La radio, entonces, y la música contenida en los acetatos instauraron el modelo de un universo cubano que empezó a fijarse en la memoria de los oyentes y con el cual éstos comenzaron a identificarse. Este universo cubano imaginado se forjó en la música caribeña y constituyó un universo de sentido para el escucha colombiano, que empezó a imaginarse Cuba, a admirar la revolución y a desear imitar ese modelo, aunque todo pudo haberse quedado en el deseo. ${ }^{114}$

No podría tocar la experiencia de la salsa en la intimidad de la escucha sin hacer caso a las formas de consecución y consumo de la música en la capital de los años ochenta. Punto neurálgico para la divulgación de la salsa, el bolero, el rock y la literatura, por mencionar solo algunos, fue la calle 19 , a la que mis fuentes se refieren siempre como «La 19», en donde comenzó una actividad cultural y comercial de gran envergadura hacia finales de los años setenta. Ismael Carreño relata cómo su paso por esta calle contribuyó a fijar tal derrotero cultural para los habitantes de la ciudad y a perfilar unas historias de vida en torno a este enclave cultural urbano:

Llegaban los libreros de la 19 y vendían discos y libros. Uno iba allá a buscar libros y discos. Y compraba uno de todo. Discos hechos en Europa; de todo lado del mundo. Se convirtió en un sitio de referente cultural. A nivel de Bogotá, la 19 era obligado. El viernes por la tarde en La 19 eso era una locura. Porque todo el mundo era oyendo música: el uno oía boleros, el otro rancheras, el otro salsa, el otro oía rock y todos ahí junticos. Y no pasaba nada.

\footnotetext{
${ }^{114}$ En este punto hubo una conexión interesante con la música de protesta latinoamericana ya que su carácter de denuncia comulgó a la perfección con el carácter social de la salsa. Igualmente la Nueva Trova Cubana se ciñó al sentido de reivindicación que invocaba la salsa. Ambas han proclamado en algún momento, abierta o tácitamente, un ideal de unidad latinoamericana, afincado en la desazón social por las represiones gubernamentales y sus excesos y en gran medida por el estado de empobrecimiento al que Latinoamérica ha sido sometida desde el imperialismo. Por esta razón, también estos géneros transitan normalmente en el gusto de los públicos salseros colombianos. El afán de denuncia y de reivindicación se reflejan también en la pintura, la literatura y en sí en la intelectualidad de segunda mitad del siglo. Son vehementes declaraciones al estilo de Coriún Aharonián que definen el espacio latinoamericano como: «todo el continente americano sometido, al sur de la frontera sur de los Estados Unidos» $(1994,189)$.
} 
Yo empecé en la 19, buscando. Conocí todo el desarrollo de La 19. Y un amigo me pasó una chiva de cómo rescatar, cómo restaurar discos y yo la perfeccioné. A tal punto que en la actualidad yo restauro discos, acetatos. Pues claro, la gente llegaba con los discos vueltos una nada y: -hermano ayúdeme a rescatar este disco. Y yo: pues, claro. Y allí en LA 19 me la pasaba todo el tiempo restaurando discos. Del uno del otro, del otro,... llegaban todos los días restaurando discos, y en la restauración de discos, empecé, lógico, a conocer muchísimo más. Porque tú lo que restauras es tu joya. Es tu disco más incunable. Y para poder saber si estaba bien, cogía y lo escuchaba y empecé a llenarme y a llenarme de conocimiento... y a coger muy rápido, rapidísimo. Y en ese ir y venir llegó un día Fernando Tascón. Y me dijo: hermano, hay un señor en la 74 que necesita que le restaure unos discos. Y le dije ¿cómo se llama el sitio? Se llama el Goce Pagano (Carreño 2014, comunicación personal).

El hecho de buscar las «pastas» en La 19 y grabar en los casetes a los grupos, cantantes y temas favoritos, e ir a escuchar salsa a casa de los amigos, impregnó la experiencia estética de la escucha de la salsa en la ciudad. La 19 fue un enclave cultural bogotano que cimentó una parte importante de la memoria sonoro-cultural de los capitalinos. La consecución de material musical en Bogotá era bastante limitada en los años setenta y principios de los ochenta, debido a que el disco llegaba expresamente por vía marítima a las costas Pacífica o Atlántica del país. Razón por la cual los comerciantes apuntalaron una estructura comercial con las dos regiones que afianzó su actividad en el centro de la ciudad, en la calle 19. En La 19 se conseguían los discos ya dispuestos o por pedido y posteriormente se encargaban listas de grabación en casetes.

En las casetas de La 19 es donde comencé a afinar más el gusto musical en cuanto a orquestas fuertes. Porque en la caseta a donde yo iba había una chica de Santa Marta, ${ }^{115}$ que en algún momento me la encontré. Entonces, yo estaba preguntando por un disco de Héctor Lavoe y Willie Colón, y comencé a conversar con ella, y ella ya preguntaba por orquestas como La Orquesta de Machito, preguntaba por discos de Graciela; ${ }^{116}$ era otro sonido, otra cosa, entonces comencé a hablar con ella de eso. Y entonces empezamos a retroalimentarnos y ella como caribeña tenía un oído muy distinto de la música. Ella llevaba ya también mucho tiempo aquí en Bogotá y estaba con salseros, sabía más

\footnotetext{
${ }^{115}$ Santa Marta es una ciudad de la Costa Atlántica colombiana, localizada hacia el noreste de Cartagena y Barranquilla.

${ }^{116}$ Francisco Raúl Gutiérrez Grillo (La Habana 1908 - Londres 1984), apodado «Machito», fue un legendario músico cubano cuyo trabajo fue muy importante en la creación del jazz afrocubano. Su hermana, Graciela Grillo-Pérez (La Habana 1915 - Nueva York 2010) fue cantante en su orquesta y una de las principales difusoras de la música cubana en Estados Unidos.
} 
acerca de eso. Y yo ya empecé a investigar más acerca de esa parte y a ampliar más el conocimiento de la parte salsera (Forero 2015, comunicación personal).

Estas interacciones fueron constituyendo la cotidianidad del melómano y del experto y, en cierta medida, de algunos intelectuales. La 19 dotaba del material preciso para agenciar un aprendizaje autónomo, el cual estaba inmerso en el deleite del conocimiento de una cultura foránea que empezaba a apropiarse y a sentirse vivida dentro de las contradicciones geo-locacionales de dos mundos: la ciudad fría y gris de interior, metrópoli superpoblada, y la ciudad costera caribeña habitada por un sonido musical perpetuo. Al mismo tiempo, la cotidianidad del melómano bogotano, que ya estaba mediada por el ejercicio de la búsqueda de los acetatos, de compartirlos, apreciarlos y discutirlos con otros, del encuentro en La 19, permitió la generación de un argot salsero que describiera aspectos determinados para la escucha y el juicio de la música. En la introducción de este texto mencionaba interesantes términos, que a fuerza de su uso han construido significantes, muchas veces solo entendibles en el círculo de aficionados o de expertos. Otras, se han apropiado tan extensamente que llegan a ser transnacionales e incluso tienen cabida en el campo de la literatura del género.

Los vocablos sabor, sonar, tumbao, ponedor de música, instrumentación o melodía, o el conglomerado de acepciones para nombrar la salsa rosa, conciertan un argot que se vuelve todo un universo representacional. ${ }^{117}$ Por una parte, este conjunto brinda una idea de cómo los melómanos observan y experimentan el género, pero por otra, a veces no es suficiente para explicar las connotaciones que alcanza cada palabra. Por lo cual, es indispensable sumergirse profundamente en la socialidad viva que acarrea la experiencia de la salsa en la ciudad y en los circuitos de escucha de la escena salsera: escuchatas, programas radiales o eventos de coleccionismo, especialmente. A continuación, haré un acercamiento sucinto a la palabra melodía, vocablo complejo, extensamente significado y usado en el ámbito.

\subsection{La «melodía», interpelación inexorable en el escucha viejaguardero}

Si en el lenguaje disciplinar de la música se habla de melodía, nos remitimos físicamente a un conjunto de sonidos musicales en diferentes alturas, organizados de

\footnotetext{
${ }^{117}$ En los subcapítulos 1.5 y 4.2 hago también una aproximación a estos vocablos.
} 
manera lógica y sistemática, que dan por resultado una idea musical coherente. Dicha coherencia debe colegir el entorno armónico o modal en que está circunscrita la idea. En fin, definiciones más técnicas o científicas pueden encontrarse a granel. Sin embargo, tales definiciones no se aproximan a la elaboración del término hecha empíricamente por los salseros; en especial, aquellos estrechamente vinculados a la erudición musical como coleccionistas, programadores, estudiosos y melómanos de alto estándar. Dados el peso y la estabilidad que ha ido adquiriendo el término, con frecuencia se encuentra su uso en la literatura salsera. Por ejemplo en los libros Salsa y Cultura Popular (Gómez Serrudo, Nelson Antonio 2013), ¿Qué es la salsa? En busca de la melodía (Santana Archbold 1992), La Salsa (Arteaga 1990), entre otros.

Pese a que la idea de esta sección es reflexionar sobre la función de la melodía en la articulación de significados para los oyentes, hay que aclarar que existen tres acepciones capitales para el término. La primera, que será el foco de este análisis, es la más compleja, ya que sintetiza múltiples carices a la hora de definir si con respecto a una canción hay melodía o no hay melodía, o si la canción tiene la melodía o no tiene la melodía. Es decir, si tiene la condición requerida en términos técnico-musicales para aplicársele el apelativo. Luego hay otra definición que nos remite al valor físico del objeto portable que contiene música del género; claro está, música con melodía. Entonces, se hace alusión al acetato, al vinilo o a la pasta y a veces al disco compacto o CD. Por último, se utiliza para sustituir el nombre del género y además, en algunas ocasiones sustituye el nombre del campo o del arte; o sea, música por melodía. De esta forma, los usos del término pueden considerarse mejor como funciones y por ende el término desempeña las funciones de condicionante, objeto y sustituto.

Entre las funciones menos relevantes comienzo por la segunda, que hace referencia al objeto portable, a la expansión de la música en materiales tangibles. Laura Angarita (2014, comunicación personal) en ocasión de una de las entrevistas para esta tesis me preguntaba: «¿Puedo llevar la melodía?». Jacobo Vargas (2015, comunicación personal) dueño y gerente de uno de los establecimientos más connotados para el comercio de la salsa en acetato, y a quien visité en su local en La 19, me comentaba con orgullo sobre la cantidad de discos que ostentaba su local: «iMire toda la melodía que hay!». Vemos con claridad que melodía señala cualquier artefacto que contenga la música grabada. En el caso de Laura, aunque es una gran conocedora y asiste a los encuentros de melómanos expertos, no tiene ningún problema en escuchar la música en 
discos compactos o en los archivos de formato MP3 que alberga en su teléfono móvil. Pareciera que por norma, el gran conocedor solo escucha discos de vinilo en tornamesa, incluso cuando está en su casa y lo hace en privado. Es más, Laura contempla entre sus gustos musicales algo de «la buena salsa balada» y, en cuanto a otros géneros, el reggaetón. Declara decididamente que ella «¡nació como reggaetonera!» (Angarita 2014, comunicación personal).

La tercera función tiene por objetivo sustituir el nombre del género de salsa viejaguardera o clásica con todo lo que conlleva conocer sobre un género: biografías, historia, contexto, evolución y todo lo relacionado con la producción de un disco, entre otros datos de interés. Acerca de la llegada de vinilos a Bogotá, Charly Valencia (2014, comunicación personal) decía: «cuando empieza el auge y llega la melodía aquí a Bogotá, que llegaban ya a la 19 donde habían las famosas casetas, y tú empiezas: voy a comprarme tal Long Play». Y añade en cuanto al aprendizaje autónomo que hizo para ser programador: «Aprendí a poner cuidado a la gente que programaba la melodía». Aparte, Charly escuchaba la radio y a un gran promotor de la salsa en Bogotá: «El famoso viejo Mike. Por él se aprendió mucho y gustó mucho la melodía también». Quique Sánchez (2014, comunicación personal) que empezó a interesarse más en el género por trabajar en una discoteca y a interesarse por ser $\mathrm{Dj}$, comenta: «Por eso siempre estaba interesado en la melodía. Tocaba conocer». Claudia Forero (2015, comunicación personal) nos cuenta sobre las escuchatas, que no tienen por objeto la competición en la presentación de los temas sino reunirse para conocer y disfrutar de la música: «No necesito tomar o consumir nada para gozarme la melodía. A veces máximo dos cervezas». Y concluye sobre los encuentros de coleccionistas que sí se consideran como competiciones: «cada coleccionista tiene su golpe y todos saben cuál es y cuánto sabe de la melodía».

En cuanto a la primera función y, con toda seguridad, la más compleja, se deduce que la melodía es una condición según la cual una pieza o tema musical posee una alta calidad en la instrumentación u orquestación, en concordancia, primero, con la cantidad de instrumentos; segundo, con la optimización de los recursos tímbricos de cada uno; tercero, con el producto sonoro del ensamble en su totalidad. En lo concerniente a este punto no se puede obviar que el oído de este tipo de salsero tiene un adiestramiento a gran escala y que rápidamente pueden dar un veredicto sobre la presencia o ausencia de melodía. Esto quiere decir que en una pieza no puede graduarse el nivel de melodía; 
simplemente, la hay o no la hay. No obstante, en algunos géneros el juicio omite la cantidad de instrumentos porque son formatos establecidos (pueden ser conjuntos bastante pequeños), normalmente de aires tradicionales, cuya calidad admite per se la aplicación del término. En efecto, la melodía llega a verificarse en los solos instrumentales o en piezas solistas.

A Laura Angarita, citada atrás, al preguntarle acerca de los sitios que más le gustan para escuchar o bailar recomendaba Son Salomé, bar salsero localizado en la carrera 7 con calle 40: «es un gran bar, excelente melodía, buen sonido». La misma informante sobre un restaurante-bar donde a menudo ponen salsa clásica o moderna interpela: «No, no tienen la melodía». Con respecto al desarrollo de los eventos, mano a mano entre coleccionistas, Claudia Forero expone los requisitos de la presentación de cada participante: «exigencia: mínimo tres piezas, con reseña del tema que se va a presentar. Tema, melodía, otras versiones». A esto añade, a diferencia de coleccionistas de vieja data, usualmente hombres, que es muy abierta con los nuevos participantes, con los jóvenes y los amateur: «me basta que tengamos el denominador común que es el gusto por la melodía». Charly Valencia nos cuenta de sus inicios en la programación: «Uno empieza rumbeando: la fiebre, la rumba, la vaina. Con los años va adquiriendo status, entonces, presta más atención a la melodía» (2014, comunicación personal).

Pese a la claridad, naturalidad y contundencia con que los salseros aplican el concepto, habría que definir el asunto de la calidad; lo cualitativo en el género. Operación, en apariencia, funcional y sencilla si obedece a una sistematización y medición de los constituyentes de la obra que conduzca a una determinación del alto o bajo aprovechamiento de los recursos sonoros. Sin embargo, la salsa es un género tan extenso, contenedor de múltiples subgéneros, que en la aplicación de determinantes de calidad, se entra en conflicto y se generan contradicciones. Por otra parte, definir estos determinantes de calidad no es objeto de este trabajo. Volvemos a la disyuntiva que genera la oralidad de los informantes, ya que el vocablo es la congregación de diversos elementos y características que se han ido determinando de manera empírica y colectiva.

En consecuencia, el término está sedimentado de variados materiales técnicos, conceptuales, disciplinares, históricos y críticos, cuya definición, como acabo de mostrar, es difícil y no debe descansar en reduccionismos epistémicos. En resumidas 
cuentas, enmarcar el término en la categoría gramatical de adjetivo es simplificar soezmente una construcción colectiva de sentido. Y hago énfasis en lo colectivo puesto que en los salseros su uso ya se ha naturalizado. Aunque he de aclarar que el uso es más corriente en el tipo de oyente más especializado, o sea, expertos en la historia, coleccionistas, programadores, entre otros. El tipo de oyente más direccionado a la escucha o la rumba casi no utiliza esa jerga.

\subsection{Salsa y construcción de sentido en la vida cotidiana}

Cuando la escucha está dirigida al apaciguamiento del fantasma, fácilmente sufre alucinaciones: creemos oír realmente lo que nos produciría placer oír como promesa del placer.

Roland Barthes 1982

Entre los ruidos, la música, en tanto que producción autónoma, es una invención reciente. Hasta el siglo XVIII inclusive, la música se funde en una totalidad. Ambigua y frágil, en apariencia menor y accesoria, ha invadido nuestro mundo y nuestra vida cotidiana. Actualmente es inevitable, como si un ruido de fondo debiera cada vez más, en un mundo que se ha vuelto insensato, tranquilizar a los hombres.

Jacques Attali $1977^{118}$

Si hablamos de vida cotidiana, de la vida misma, hablamos del trasegar por diversos territorios a lo largo del día. Quizás micro-territorios que entendemos como lugares caracterizados por ciertas señas que definen su esencia. Gran parte de estas señas pertenece al entorno auditivo; son audibles y pueden estar impresas en él naturalmente o pueden ser el resultado de la intervención humana con los aparatos tecnológicos que se manipulan en el diario vivir; los ruidos.

Para los mamíferos, su territorio está jalonado de ruidos y olores; para el hombre fenómeno a menudo desestimado- también es sonora la apropiación del espacio: el

\footnotetext{
118 Traducción tomada de la publicación en español Ruidos. Ensayo sobre la economía política de la música (Attali 1977, 11).
} 
espacio doméstico, el de la casa, el del piso (el equivalente aproximado del territorio animal) es el espacio de los ruidos familiares, reconocibles, y su conjunto forma una especie de sinfonía doméstica: los diferentes golpeteos de las puertas, las voces, los ruidos de cocina, de cañerías, los rumores exteriores: en una página de su diario, Kafka describe con exactitud (¿acaso la literatura no es una reserva de saber incomparable?) esta sinfonía familiar: «Estoy sentado en mi habitación, es decir, en el cuartel general del ruido de todo el piso; oigo los golpes de todas las puertas, etcétera» (Barthes 1982, 244). ${ }^{119}$

Barthes enfatiza el entorno sonoro de la casa y señala metafóricamente la «sinfonía familiar» como la condición que determina la apropiación del espacio doméstico. La apropiación sonora de un lugar se basa en el reconocimiento de las señas audibles; un lugar puede ser identificado por estas señas. Entre los ejemplos de Barthes está la voz; la voz del otro, decisiva en el reconocimiento del territorio físico o de un territorio abstracto o psicológico. Ahora, cuando el ser humano necesita intervenir en el entorno sonoro, la música es un ingrediente de primer orden, sobre todo cuando es elegida a voluntad en vez de ser impuesta por un tercero. Si hablamos de identificar un entorno sonoro, las personas más afectas a la música, los melómanos, incluyen en su sinfonía, diariamente, la música de su preferencia. La música se convierte, entonces, en el sello particular de ciertas acciones cotidianas. Esperanza (2015, comunicación personal) comenta: «Mientras preparo un tinto ${ }^{120}$ coloco salsa». La conexión entre el café que se prepara en su casa y la música ha logrado tal normalidad que ahora se enmarca, prácticamente, entre ritual y norma: el café no se prepara sin música.

La rutina diaria de Alex está cargada de actividades. Es músico, trabaja, y al final del día se encuentra muy cansando. Cuando llega a casa, la mejor manera de desconectarse de la agobiante rutina de la jornada, es escuchar salsa:

Eso me lleva a salirme de la realidad del cansancio, un poco. Entonces, lo primero que hago es colocar la salsa, o las salsas, que más me gustan, o alguna canción que me ha llamado la atención en los últimos días... pero me lleva como a otro estado; como a un estado de deleite; como de goce interior, así no esté bailando en ese momento. [...] En ese momento del día me hacen sentir algo distinto; por ejemplo, si estas son canciones que, aunque su contenido es romántico, no dejan de ser canciones en un tempo, musicalmente hablando, que es propicio para bailarlo. No son canciones lentas, ya casi

\footnotetext{
${ }^{119}$ El entrecomillado que aparece sobre la última frase es mío.

${ }^{120}$ Preparación de café a modo de infusión de gran consumo en el territorio colombiano.
} 
llegando a un bolero, no. Son canciones con un tempo para bailarlas. Entonces, eso realmente me genera como estar activo nuevamente. Es como si yo tomara una ducha y saliera renovado. Entonces, eso me prepara para hacer las funciones que tengo que hacer luego en la casa: que tengo que hacer un trabajo, que trasnochar por equis o ye razón. Es un impulso (2014, comunicación personal).

En concordancia con este testimonio, Esperanza, citada anteriormente, ama de casa y administradora del Café, arte y pasión, plantea una posición categórica con respecto a la escucha de la salsa en casa. En los momentos de hacer oficio el fin de semana, ${ }^{121}$ que son momentos de total tranquilidad, las actividades están gobernadas por la salsa. El lugar que determina el oficio es la terraza en la planta superior de la casa. En la terraza Esperanza tiene instalado su equipo de sonido y parte de la música que está contenida en discos compactos. También posee discos de vinilo pero están almacenados y ya no los utiliza. Lo primero que hace es poner el equipo a «todo volumen» y comienza la faena que se va mezclando con el baile y el canto. Normalmente los episodios de baile van encontrando mayor protagonismo y suelen refrenar las otras actividades. Esperanza baila sola o baila con su hermano, que se encuentra usualmente en un local comercial de la primera planta de la casa. De este modo, cuando él escucha la música, que se oye en todo el vecindario, sube para acompañar a su hermana como bailador pareja en la discoteca que se monta temporalmente en ese lugar y, como advierte ella, él es un magnífico bailador. La terraza es el lugar más ritual de la casa, en el que la estesis sonora pareciera no tener límites, pues el mundo de sentido en la alegría y el bienestar que le produce la salsa, es inconmensurable:

¡Uy! ¡Profe usted me viera sola bailando en esa terraza! Yo hago de cuenta que estoy en la discoteca más popular, más bonita, y eso me doy unos conciertos. Porque mi marido es de los que hoy en día,... porque cuando bailaba y todo eso, lo hacía con todas menos conmigo. Y hoy en día dizque no le gusta, según él, no le gusta. Entonces, con él no puedo compartir, entonces lo hago sola. O a veces me llevo a mi hermano. Llega y ¡venga pa’cá! Y me pongo a bailar con él porque a él si le fascina la salsa. Baila súper bien la salsa. Y ahí los dos bailamos. Nos damos un concierto de música y de baile.

\footnotetext{
${ }^{121}$ En Colombia se denomina oficio a las tareas domésticas de organización y limpieza de la casa; lo que en España se denomina faena.
} 
Termino cansada como si hubiera estado en una discoteca; mejor dicho: ¡chévere! ${ }^{122}$ (García Manrique 2015, comunicación personal).

De joven ella no frecuentó discotecas, su madre nunca se lo permitió, pues aseveraba que era un sitio de prostitutas. Se casó a los 16 años y fue su marido quien la llevo por primera vez a una. Es una experiencia que demarca la narratividad de Esperanza profundamente, de tal forma que «la discoteca» es un componente ineludible en el relato de juventud.

Fui a esa discoteca y no, yo no quería salir de allá. Qué cosa tan chévere y bailé salsa y había... Me acuerdo mucho que esa discoteca se llamaba... no sé si exista hoy en día, La Jirafa Roja; nunca se me olvida, y era solo salsa, solo salsa. Iban unos bailarines y eso esa pista... y yo... O sea a mí nunca nadie me enseñó a bailar. Nadie. Dios me mandó con ese don. Dicen que yo bailo muy bien, y la salsa, no sé pero me salen pasos, y a mí nadie me enseñó, nadie (García Manrique 2015, comunicación personal).

Lo que Esperanza vivió en La Jirafa Roja -la discoteca que visitó cuando era joven- se reproduce en la pista de la terraza de su casa. La música a todo volumen, bailar sola o acompañada de su hermano, sin importar nada ni nadie. La realización de la felicidad aparece nuevamente en este aparte desde la posibilidad y el poder de construir un mundo que da sentido a su existencia. Ella misma declara que es una «enferma» del sonido, de la salsa. Cuando se despliega este mundo, los otros y los otros mundos, quedan realmente anulados. De hecho, esto le ha supuesto algún problema:

Y los viernes, como llego en plan de hacer aseo para los sábados no tener que pensar en hacer nada, ahí sí es cuando prendo mi equipo en la terraza y a todo volumen. Una vez me echaron la policía por eso. La vecina. Eran las 10:00 am, el sábado, y yo estaba haciendo aseo, y yo sin música no sé trabajar, y en mi casa menos. Y cuando llega la patrulla: bájele un poquito porque su vecina está molesta. Le bajé. Yo dejé que se fueran y apenas se fueron: ¡Pam! Le subí toda, ¡toda! Entonces, yo estaba pendiente, y apenas veía que bajaba otra vez [la patrulla], porque era obvio que ella volvía a llamar. Entonces, apenas veía que venían, iba y le bajaba. Entonces, ellos pasaban y no oían ruido, y como extrañados... yo los dejaba que otra vez se fueran y otra vez le subía. Se veía bueno, hasta chistoso (García Manrique 2015, comunicación personal).

\footnotetext{
${ }^{122}$ Chévere es un vocablo utilizado en Colombia, y algunos otros países latinoamericanos, que equivale a guay en España.
} 
La casa y la música son una unidad, no pueden estar dislocadas. Esperanza (2015, comunicación personal) concluye: «Tengo unos [discos compactos] en el primer piso que también tengo equipo. Es que soy como enferma. Entonces, cuando llego al primer piso mi equipo ahí, y en la terraza, mi equipo allá. El todo es que no me falte la música».

En proporciones similares Lucy, una de las informantes de DeNora, relata la relación que tiene con piezas musicales específicas; en su caso, los Impromptus de Franz Schubert. En franjas de actividad laboral o quehaceres domésticos que conllevan demasiado estrés, Lucy utiliza los Impromptus para proveerse de una sensación de «calma» interior $(2000,16)$; la ayudan a relajarse. Claro está que no es el impromptu per se el que estimula el cambio de ánimo, ya que hay toda una historia personal y familiar detrás de este uso y porque ella acondiciona los elementos del entorno como la silla o la chimenea para disponerse a escuchar. En cuestión de minutos se ha operado el cambio que necesita Lucy. Este relato enmarca la correlación entre la música y el proceso de auto-regulación emocional; lo cual es una clara exposición de cómo las personas usan la música con la finalidad de acondicionar el temperamento, el genio y en sí el estado interior en momentos determinados. DeNora explica que:

En las condiciones históricas en las que se produce la tensión entre lo que un individuo debe hacer y lo que prefiere hacer, o entre cómo se siente y cómo quiere sentirse, surge el problema de la auto-regulación y con él la cuestión de cómo los individuos negocian entre los polos de necesidad y preferencia, entre cómo piensan que deben sentirse y cómo se sienten $(2000,52) .{ }^{123}$

En el nivel de la emoción la auto-regulación indica que el mismo oyente induce por medio de la escucha el ánimo que desea o necesita para sentirse bien consigo mismo y emprender entonces determinadas tareas cotidianas. Por lo tanto, no es simplemente el artefacto quien propicia el clima de la auto-regulación: es el actor quien provee a la música del poder necesario para generarla $(2000,16)$. En ese sentido, la autora propone que hay un proceso reflexivo que permite al oyente discernir que música le hará bien o no para cumplir sus expectativas emocionales: «Cuando los informantes están eligiendo

\footnotetext{
${ }^{123}$ «Under any historical conditions where tension between what an individual 'must' do and prefers to do, or between how he or she feels and how he or she wishes to feel, the problem of self-regulation arises and with it, the matter of how individuals negotiate between the poles of necessity and preference, between how they think they ought to feel and how they do feel».
} 
la música como parte del cuidado de sí mismos, están participando en una actividad de articulación consciente, pensando con antelación en la música que podría "funcionar" para ellos». ${ }^{124}$

Alex, Esperanza y Lucy han invertido intencionalmente en su música la emoción que debe proveerles; de esta manera, al evidenciar que es una operación tan personal entendemos por qué en distintos actores, estos efectos pueden ser contradictorios. Si para Alex la salsa implica el descanso y la calma, para Esperanza es todo lo contrario; le provee del motor energizante en pro de realizar actividades físicas que necesitan mucha dinámica, entre ellos los oficios o faena de la casa. DeNora concluye que desde el acto de conferir a la música ese poder es posible la dinámica dentro de la relación artefacto, escenario y actor para que el estado de ánimo de un escucha cambie convenientemente a favor de satisfacer sus deseos o necesidades.

Ahora, los territorios que habita la gente pueden estar intervenidos por agentes sonoros externos que impactan sobre el lugar habitado. En la casa de Alejandro, la salsa actuó específicamente como catalizador de procesos sonoros, cuando voces y ruidos ajenos al espacio doméstico colonizaron el entorno en una urdimbre de caos auditivo que impedía el bienestar. Acallar el alboroto externo era una necesidad que requería una solución apremiante y efectiva; la salsa apagaba los sonidos invasores que invadían la casa y, en consecuencia, elaboraba un universo sonoro que podía traer impresa, tácitamente, la consigna: «todo está bien». Para Alejandro (2014, comunicación personal) escuchar música funcionó cotidianamente en dos situaciones particulares en su momento. el ruido de fondo que contaminaba el territorio cotidiano y, luego, el espacio silencioso que pedía ser habitado por música.

Cuando viajo a España, vivimos en el centro [de Barcelona] con Gerard y resulta que los ruidos de la manzana son tan fuertes, o sea, se escucha la música de los otros, los ruidos, el butanero, la señora que no sé qué... bueno, se escucha todo, a tal punto en que uno pone la música para esconder el ruido de fondo. (Gracias por el ruido de fondo, como decía el argentino éste...). Porque es una manera de apagar el ruido de todo lo que no quieres escuchar. Entonces, comenzamos a escuchar mucha salsa ahí, y luego en el trabajo en la montaña, también. Fue como otra época en la que trabajando escuchábamos mucha salsa. Pero eso, ya era, él y yo en la montaña, sin necesidad de poner música. Era

\footnotetext{
124 «When respondents are choosing music as part of this care of self, they are engaging in self-conscious articulation work, thinking ahead about the music that might 'work' for them».
} 
todo lo contrario. Era la calma total y ahí también terminamos por llevar la salsa. [...] Estamos cocinando, estamos trabajando, entonces la salsa se vuelve un fondo como lo era cuando estábamos en el apartamento y necesitábamos... yo necesitaba especialmente apagar tanto ruido y ponía la música. Era una manera de un ruido de fondo. Y en la cocina, claro tú vas haciendo. Es lo que no tiene la televisión. En la televisión tú estás conectado a una imagen y con la música tú puedes estar haciendo muchas cosas. Cuando escuchas radio, igual. Y lo que hacíamos era trabajar; cocinábamos; cocinábamos con ritmo.

En concordancia con la colonización del territorio sonoro por agentes externos, que irrumpen y degradan la tranquilidad de lo cotidiano, Roland Barthes ([1982] 1986, 245) anota lo siguiente:

Cuando el fondo auditivo invade por completo el espacio sonoro (cuando el ruido ambiental es demasiado fuerte), la selección, la inteligencia del espacio, ya no es posible, la escucha resulta perjudicada; el fenómeno ecológico que llamamos hoy día la polución -y que lleva camino de convertirse en un mito negativo de nuestra civilización mecánica- no es nada más que una alteración insoportable del espacio humano, en la medida en que el hombre exige reconocerse en él: la polución lesiona los sentidos que sirven al ser humano, del animal al hombre, para reconocer su territorio, su hábitat: la vista, el olfato, el oído. Respecto a lo que ahora nos interesa, existe una contaminación sonora, sobre la que todo el mundo, del hippy al jubilado, está de acuerdo (merced a los mitos naturalistas) en afirmar que atenta contra la misma inteligencia del ser vivo, inteligencia que, stricto sensu, no es sino su capacidad de comunicarse adecuadamente con su Umwelt: la polución impide escuchar.

En el caso de María (Rosas Salazar 2014, comunicación personal), que trabaja en una Universidad bogotana y la mayor parte de su día transcurre allí, la escucha se restringe a la casa. Su apartamento es el cuartel personal de la tranquilidad y el bienestar y la música es un ingrediente que define tales emociones.

Cuando yo estoy aquí, en el apartamento, por ejemplo, en la noche cuando llego, yo busco música salsa o pongo los $\mathrm{CD}$, que son pocos, pero escucho la música. Los sábados y los domingos cuando yo estoy en mis quehaceres, es la música que me anima. Y si no, no puedo hacer nada. Es decir, si yo pongo musiquita ahí, de esa romántica: no. No me anima a hacer nada; ni leer. En cambio con la música salsa, sí. Diferente, sí, ya cuando estoy en el trabajo, pues, ni siquiera escuchamos música. Pero sí cuando yo necesito estar 
alegre, eso me motiva para todo. Si tengo que hacer los oficios aquí es la música la que me activa. [O sea, tú los oficios, sin salsa: no; ése no es plan] ¡No, no es posible! Dicen música para planchar, ${ }^{125}$ pero yo no sé quién plancha con esa música, Yo, no. Necesito estar activa, para mí la salsa sí es como esa actividad, esa emoción, me llena de ánimo, me llena de euforia.

Para María la identificación visceral se allana en el sonido, el cual está conectado muy fuertemente con una historia personal y familiar ligada constantemente a la salsa. Si se le pregunta por cantantes, conjuntos, letras, nombres, no le interesa entrar en detalle. Menciona lo más genérico y de paso ha memorizado, junto con otros miembros de la familia, estrofas de algunas canciones. En su equipo de sonido tiene una muy pequeña colección de discos compactos, originales o que su hijo le ha grabado, y ella los elige al azar. Cualquiera de esos discos le proporciona el sonido indispensable para entrar en acción con la música. En la revisión de su colección saltan a la vista El Gran Combo de Puerto Rico, los clásicos de la Fania: Héctor Lavoe, Willie Colón, Rubén Blades, Richie Ray y Bobbie Cruz, entre algunos otros. De este último le impresiona la sedosidad de su voz y la amplitud de su registro. Resalta la facilidad para cambiar de graves a agudos «naturalmente, sin ningún esfuerzo». En definitiva, esta voz la hipnotiza. Pero al intentar profundizar en los detalles de corte paratextual ${ }^{126}$ de una producción -datos que acompañan el sonido- no se obtienen resultados, puesto que esa información no es vital para la realización de su bienestar en la música. Lo importante es el sonido alegre, en sí, de la salsa y las vivencias familiares que conecta a la experiencia.

Francisco Cantor escucha en promedio cuatro horas diarias de música acompañado de unos tantos cafés. En su apartamento dispone de un estudio donde alberga una cuantiosa colección de vinilos recolectados en el lapso de unos cuarenta años, en perfecto estado de conservación al igual que las carátulas y debidamente clasificados por «orden de

\footnotetext{
${ }^{125}$ En Colombia el apelativo «Música para planchar» empezó a utilizarse a finales de los noventa para referirse a las baladas españolas y latinoamericanas de corte romántico de los años setenta y ochenta, que tenían gran presencia en los medios de comunicación. Los artistas destacados en ese género, que tuvieron grandes audiencias en el país, fueron, entre otros, los mexicanos Yuri, Juan Gabriel, los españoles Raphael, José Luis Perales, el brasilero Roberto Carlos, o los colombianos Isadora, Billy Pontoni o Galy Galiano. Música para planchar indica que las personas que la escuchan son aquellas que hacen el oficio doméstico; lo cual puede denotar algún matiz peyorativo.

${ }^{126}$ En el área de estudio de la intertextualidad, el paratexto es un elemento interno o externo de una obra no solo un texto literario sino cualquier artefacto posible de «leerse», para el caso musical de «escucharse»- que Gérard Genette define como: «título, subtítulo, intertítulos, prefacios, [...] y muchos otros tipos de señales accesorias, autógrafas o alógrafas, que procuran un entorno (variable) al texto y a veces un comentario oficial u oficioso del que el lector más purista y menos tendiente a la erudición externa no puede disponer tan fácilmente como lo desearía y lo pretende» ([1962] 1989).
} 
importancia». Este orden de importancia está relacionado en gran medida con el orden cronológico de la evolución o aparición de los ritmos cubanos. En la sala se encuentra instalado un equipo de sonido con tocadiscos, cuya aguja es una de las más especializadas para la reproducción de acetatos. De cualquier disco que pudiera elegirse de la notable discoteca Francisco brinda los datos de su producción e historia al detalle. El sentido de coleccionar no es acumular, es saber, y la cantidad de discos no importa sino la música que esté allí contenida. Así que gran parte de su tiempo lo ha dedicado a conseguir e interpretar la información de toda la música que posee, en especial, la cubana. A través del sonido cubano, Francisco ha armado también su historia personal de Cuba y ha llegado a asumir el país caribeño como su segunda patria.

Soy más cubano que cualquier cubano, muchas veces, y con los mismos cubanos he tenido discrepancias. Dicen: pero Francisco si usted no nació en Cuba, escasamente fue una o dos veces... Les digo: para mí, mi música cubana es de mi corazón; aclarando que también poseo el corazón en Puerto Rico, Venezuela, Colombia, obviamente, perdone que no la haya nombrado, en fin. Pero mi pasión es la música cubana. Entre paréntesis: hay música de hace más de cien años que aquí la tengo en discos (Cantor 2015, comunicación personal).

Con unas necesidades de escucha distintas a las de María, Francisco funda su experiencia vital con la música en un ejercicio disciplinado y en la búsqueda del saber histórico y musical de las obras que van nutriendo su colección. Pese a que la vida laboral de Francisco, que ya ha culminado, se basó en su trabajo en la Banca, el resto fue el deporte y la música. A ambos se consagró con total seriedad. Pero la música no ha terminado para él, a sus 78 años con una jovialidad inusual, el conocimiento por la música y su compromiso con ello determina su cotidianidad y gran parte de su socialidad. Cada cosa que escucha está portentosamente documentada con la información que proporcionan las carátulas de los álbumes, las revistillas que traen consigo, los libros que ha ido adquiriendo, artículos, fotocopias y demás formatos que contengan información. Toma notas a mano de los datos que considera más importantes, y está siempre confrontando la información. Estas tareas cotidianas confieren lógica a la disposición de sus acetatos, a la información que comparte verbalmente, a la programación musical que prepara para alguna presentación radial o pública -encuentros 
de coleccionismo especialmente- y le otorgan dinámica y vitalidad a su vida dentro de casa y fuera de ella. ${ }^{127}$

Las vivencias de Alex, Esperanza, Alejandro, María y Francisco anuncian y demuestran la vitalidad de la música como dispositivo para la autorregulación emocional, como objeto de la estética que media en la construcción de significados o como mediadora de la identidad y la autopercepción. No obstante, en los aspectos señalados hay un factor que triangula las experiencias señaladas y es la territorialidad demarcada en parámetros sonoros. Para Barthes, más que un proceso natural es un proceso visceral: marcar el territorio con las señas sonoras es un gesto animal. El espacio señalado por el sonido impide al extraño penetrar ilegalmente el territorio, pero además, cuando está presente la música, dicho espacio se amolda a la forma adecuada y precisa en la cual puede ser apropiado; es como si la música ofreciera las garantías del confort para ser considerado «territorio personal» y por ende brindara la satisfacción de ser habitado. En el espacio privado de la cotidianidad, la música es más propensa y más apetecida para establecer niveles de autoregulación emocional, porque los territorios privados gozan del control del oyente y él puede intervenirlos a través del sonido, incluso, para informar la pertenencia y dominio del lugar.

Por otra parte, en estas experiencias lo simbólico tiene una participación activa, como lo ocurrido en la terraza salsera de Esperanza. En primer lugar, porque los melómanos reciben el género per se inscrito en la clasificación convencional. Histórica y culturalmente se le han atribuido las propiedades inherentes de ser un género bailable, para el disfrute del cuerpo y de los sentidos, y de ser el género de la alegría. Desde esta sedimentación hemos visto que el salsero, el bailador, ha modelado un ideal de libertad, que en Esperanza es una realización contundente. El cuerpo sin ataduras físicas ni

\footnotetext{
${ }^{127}$ Con Francisco Cantor tuve la oportunidad de conversar en diversas ocasiones. El día de la entrevista «formal» Francisco organizó para mí, prácticamente, una presentación de la historia de la música cubana, asunto que me sorprendió honda y gratamente. Yo le había informado con antelación sobre los puntos de la entrevista, que se centraban en su historia personal con la música y en su experiencia de escucha del género. Cuando llegué a su apartamento vi dispuestos en los muebles de la sala y el comedor, distintos conjuntos de acetatos. A lo largo de la entrevista, él iba desplegándolos sobre la alfombra y uno de los sofás de la sala. Mientras íbamos hablando de su vida musical, él iba desplegando, además, la historia de los ritmos cubanos e íbamos escuchando todo el tiempo muestras representativas de cada aire. De vez en cuando me pedía que lo pusiera a prueba con algún tema, y me daba los datos exactos de la historia y de la producción. La felicidad de esta labor era inmensa y contagiosa. Fueron alrededor de cinco horas compartiendo y escuchando música y constatando de primera mano cómo se establece un mundo de sentido que vincula no solo la experiencia estética del sonido, sino además la realización personal en el conocimiento. Constatando, al mismo tiempo, que dicha experiencia estética se nutre o se acondiciona con las disposiciones que brinda el saber sobre el género.
} 
atavismos socio-comportamentales. Esto parecería contradictorio si vemos el baile en pareja, en el cual los dos bailadores deben seguir unos pasos en los que se acopla el uno al otro dentro del compás de la clave. Pese a esto, el movimiento es amplio y distensionado, permite la improvisación y le otorga al bailador la posibilidad de anexar movimientos corporales a su gusto y habilidad, procurando una impronta, un sello, una marca personal, que identifica el paso de cada persona. En su jerga, el tumbao, el sabor de cada bailador. Esperanza mencionaba, por ejemplo, el sabor que tiene el baile de su hermano, pareja ocasional el fin de semana en su terraza. Al mismo tiempo, la salsa es la irreverencia y hay una translación de esta irreverencia a la actitud de Esperanza con su vecina, con su entorno.

Tal carga simbólica tiene una función en la performatividad; mas, el yo que se constituye en la performance no es un yo de la representación, del anhelo o del fingimiento; no es un yo meramente ritual. Es un yo real que no se imagina lo que está sucediendo en su cuerpo y su entorno, sino que lo vive como una experiencia efectiva de realización. Un equipo de sonido en la terraza de un barrio popular con El Gran Combo o Gilberto Santarrosa a todo volumen, convierten el lugar en La Jirafa Roja, y el oyente es el mejor bailador de la discoteca. Nada más importa, la norma que rige la conducta social desaparece (la vecina molesta, la policía que interviene, el retraso en la faena de la casa). Todo pasa a segundo plano porque la performatividad en el ritmo salsero ha elaborado un yo que no se ciñe a las constricciones de lo establecido. La salsa ha hecho posible un yo de poder.

\subsection{Desplazamiento de la música en la re-creación y reproducción de la salsa}

Me parece que el medio esencial de la música, la base de sus facultades expresivas y el elemento que le da su calidad de única entre las artes, es el tiempo, hecho vida para nosotros a través de su esencia expresiva: el movimiento. ${ }^{128}$

\footnotetext{
128 «It seems to me that the essential medium of music, the basis of its expressive powers and the element which gives it its unique quality among the arts, is time, made living for us through its expressive essence, movement» (Sessions 1979, 6).
} 
La estesis que se genera con la música está gestionada por la escucha. Aunque esta premisa pareciera obvia es esencial recurrir a ella porque la música posee algunas características que no albergan otros tipos de artefactos o dispositivos sensoriales. La primera, es la posibilidad de reproducción inmediata que se puede realizar de las melodías, de las líricas y/o de los timbres de los instrumentos -imitarlos con el canto o con el tarareo-. O sea, reproducir corporal o físicamente la música. La segunda es la posibilidad de re-creación -recordar el sonido total o parcialmente- de las melodías y los ritmos; en ese caso, valerse de la memoria para vivenciarlos nuevamente. Asimismo, cuando la música es re-creada tiene el potencial de definir mejor una experiencia vital asociada a ella en términos de su localización temporal, su ubicación geo-referencial y datos particulares, históricos o contextuales, enmarcados en la vivencia. A partir de estas posibilidades, cuando las personas hacen elaboraciones narrativas la música ofrece una importante batería de datos, información o conocimiento, que articula, aporta y completa el sentido de la experiencia. Sin embargo, conviene tener presente que no toda esta información es verbalizable, decible, por lo cual Pelinski anota como objetivo central de su tesis:

Mostrar cómo nuestra condición humana de seres corporalizados está imbricada en diversos aspectos de nuestra práctica y conceptualización musical corriente. En particular, intento mostrar cómo siendo la percepción un proceso primariamente cerebro-corporal, las sombras de su preconceptualidad y prerracionalidad se extienden sobre nuestras prácticas musicales en forma de hábitos motores, esquemas corporales de acción, imágenes auditivas, etc. que no dependen de una racionalidad deliberada (Pelinski 2005, s.p.).

Por consiguiente, es menester acercarse a algunas de las relaciones que surgen entre el tiempo, la música, el cuerpo y la narrativa.

El sonido y la música transcurren en lapsos definidos de tiempo; lo que determina que la música sea una expresión primordialmente temporal. Este tiempo físico u objetivo, que es el tiempo cronológico, está definido por la física en múltiplos y submúltiplos de segundo. Por lo tanto, es físicamente medible. Así, damos perfecta cuenta de la duración de una pieza musical o de un evento sonoro. Pero hay otro tipo de temporalidad en la 
cual se registra la memoria personal de cada individuo. La música puede ser recordada de manera intencional; puede aparecer en la memoria «fortuitamente» o quizás motivada por un factor externo. Así pues, el tiempo no solo transcurre en el mundo físico y objetivo. Para observar el tiempo de los recuerdos que conforman la memoria, y en especial, el de la música, que necesariamente transcurre en una dimensión temporal, «la definición física del tiempo es incapaz de explicar las condiciones psicológicas de la aprehensión del tiempo mismo» (Ricoeur [1985b] 2009, 995). Este tiempo psicológico o subjetivo, que concede al recuerdo musical otra dimensión temporal, es «la experiencia de flujo, duración, lapso y proceso que un individuo experimenta de diversas maneras, sea en su vivencia consciente, durante una sucesión de estados mentales, cuando calcula lapsos para actuar, recuerda eventos pasados que fija cronológicamente o planea sus actos en referencia prospectiva a un futuro probable» (Díaz 2011, 379).

Si nos fijamos en la experiencia temporal del recuerdo de eventos consideramos el sonido musical, en consecuencia, como un evento. En el caso de la memoria musical individual dichos eventos sonoros no están necesariamente fijados en orden cronológico. A lo que acudimos es a la recuperación de la sensación sonora, y el «experimentar de diversas maneras» esa recuperación lleva consigo el aporte del entorno, tanto en el momento en que se produce el recuerdo como en el recuerdo mismo del evento que ha estado enmarcado en un contexto específico:

El tiempo subjetivo depende del movimiento de las funciones integrales del cerebro en estrecha coordinación con movimientos y señales del mundo externo. ${ }^{42}$ Como sucede con el resto de las sensaciones y percepciones, el tiempo subjetivo lejos de ser un evento puramente privado de representación o un evento puramente cerebral está en estrecha relación con múltiples fenómenos corporales y conductuales a través de los cuales se inserta y se deriva de circunstancias cronológicas plasmadas en la cultura. La relación entre los factores temporales internos y externos es muy estrecha, de tal forma que los relojes interno y externo se ajustan, se entrelazan y se complementan. Además, hay evidencias [de] que todo conocimiento sensorio-motriz se ubica en contextos sociales y ambientales que requieren sincronización con actividades, ciclos y relojes externos al sujeto (Díaz 2011, 388-89). ${ }^{129}$

\footnotetext{
${ }^{129}$ El texto citado por el autor es: Clark, Andy. «Time and mind». The Journal of Philosophy 95 (7):
} 354-376. 1998. 
Ese tiempo subjetivo que se establece en concordancia con el entorno de las personas, es el que sirve a este análisis para entender cómo se desplaza el sonido que se ha afincado en la memoria personal y, naturalmente, también colectiva. Es un tiempo interno que ayuda a constituir y establecer la subjetividad; un tiempo interno desde donde se operan y se dinamizan los recuerdos y, por consiguiente, en el cual se dinamiza el recuerdo de la música. La música es una expresión temporal, siempre se experimenta en el tiempo, bien sea físico cronológico o subjetivo psicológico, y es ante todo una expresión temporal debido a su naturaleza no tangible. A la vez, es espaciotemporal ya que siempre hay un lugar en el que transcurre la sonoridad de la música. Cuando se experimenta en el tiempo subjetivo de cada individuo nos damos cuenta de que éste es el tiempo en el que transcurren los recuerdos, la memoria de acontecimientos y hechos acaecidos remotamente o recientemente. De esta forma, entendemos que la música se mueve en una dimensión espacio-temporal subjetiva o psicológica; se desplaza en esa dimensión como recuerdo y se recupera y vivencia nuevamente. Esta es la primera señal de desplazamiento del sonido, y es una señal particularmente activa en la música porque es un recuerdo dinámico. Si recordamos una escultura o una pintura, el recuerdo es el de una imagen estática. En cambio, en la música el recuerdo es dinámico porque el sonido está transcurriendo en el tiempo y la remisión a movimiento es consustancial en el evento sonoro.

A partir de estas claridades puede definirse que una forma de re-creación de la música es la experiencia de su recuerdo; lo que significa volver a crearla en la mente. La música recordada es música que vuelve a ocurrir, si bien no física o externamente, sí mentalmente. Si de las formas en las que transcurre el tiempo tratara esta tesis, habría que mencionar muchos otros tipos de temporalidades físicas y psicológicas que se presentan en la estesis sonora; pero me detengo únicamente en la que se refiere a la temporalidad en la cual transcurren los recuerdos personales, que muy a menudo son evocados por la música, o bien a la música misma como recuerdo. Reitero desde esta consideración, que la evocación es un primer tipo de desplazamiento, ya que sustenta un movimiento en el tiempo que puede leerse como un punto de partida que es un «antes» hasta un punto de llegada que es un ahora, es decir el recuerdo por sí mismo.

Mark Johnson (2007) advierte que la música es un modo de organización del tiempo, por lo cual ésta se experimenta como movimiento. Al escuchar música sentimos que nos desplazamos hacia otro lugar, y este desplazamiento se entiende como un cambio 
temporal. No obstante, se percibe una doble direccionalidad: la música viene hasta nosotros en el momento presente, pero también nosotros podemos transportarnos a ese momento remoto en que ocurrió el evento sonoro. Al describir la música o los eventos relacionados con la música, se acude con bastante frecuencia a las metáforas de movimiento. Daniel es compositor, violinista y director del conjunto La Real Charanga. Como lo manifiesta el título de charanga, ${ }^{130}$ la música que interpreta es de estilo cubano, aunque aprecia de igual forma la salsa neoyorquina. Sobre su predilección por los ritmos cubanos, afirma:

Sí, tienen otro «viaje», es otra onda; de hecho los ritmos son los mismos, pero cambia un poco el sentido del viaje. La salsa neoyorquina tiene otro viaje y lo cubano es otra película, aunque se manejan los mismos ritmos, pero sí se siente la diferencia, el viaje es más rico, el son es más chévere (Díaz Lepiry 2014, comunicación personal).

Normalmente, los salseros se remiten a la música para recuperar y actualizar emociones o sensaciones que causan la experiencia mental o corporal de bienestar. Apoyando el argumento de Daniel, exactamente desde la perspectiva del recuerdo sonoro, María comenta que siempre se dirige a la salsa por la alegría que le causa, porque inequívocamente, la salsa la sumerge en un estado de euforia y dicha que trastoca completamente la realidad material que pueda estar ocurriendo: «Recordar la música y las canciones, eso sí me llena de mucha alegría. Con esta entrevista, entonces, estoy feliz» (Rosas Salazar 2014, comunicación personal). En efecto, la conversación con María estuvo ambientada en su experiencia estética con la música y los recuerdos familiares que, sin lugar a dudas, están entretejidos en la música; su grupo social es la familia, la cual se conecta estrechamente con la salsa. Por lo tanto, la entrevista se constituyó, en parte, en un encadenamiento de recuerdos sobre vivencias personales asociadas al sonido salsero y a la alegría, donde un recurrente «viaje» de ida y vuelta ponía en primer plano la re-creación del sonido en el mundo subjetivo de María.

Cuando los informantes narran memorias o recuerdos vinculados con la música, se comprueba la propiedad que ésta posee para localizarlos y organizarlos temporalmente, como veremos en el relato de María. Frith supone que las funciones de la música

\footnotetext{
${ }^{130}$ La charanga es un tipo de conjunto musical cubano, cuyo formato está constituido por flauta, violines, contrabajo, conga, timbal, güiro y piano. En Bogotá, y en Colombia en general, es muy difícil encontrar un conjunto de charanga. En el caso de Daniel, es una tradición puesto que el gusto por la música cubana le viene por herencia y además su familia es de músicos; abuelos, tíos, padres y hermanos son instrumentistas e interpretan música clásica y popular.
} 
enfatizan la creación de identidad, el manejo de los sentimientos y la organización del tiempo. Si bien el autor trata esta última con algo de ligereza, ya que carece de referencias y mezcla y/o confunde asuntos de temporalidad y memoria, de sujeto individual y colectivo, sí nos brinda una reflexión abarcadora de la intervención de la música en la organización del tiempo, atribuyéndole la propiedad de generar espacios en los cuales transcurren las vivencias. En resonancia con tal propiedad, indica:

Una de las consecuencias más obvias de la organización musical de nuestro sentido del tiempo es el hecho de que las canciones y las melodías son a menudo la clave para recordar cosas que sucedieron en el pasado. No me refiero simplemente a que los sonidos como las imágenes y los olores- desencadenen recuerdos asociados a ellos, sino más bien que la música en sí misma dota a nuestras experiencias vitales más intensas de un tiempo en el que transcurrir (Frith [1987] 2008, 425).

Por añadidura, dado el carácter narrativo de la experiencia que se recoge en este análisis, es necesario comprender que: «Recordamos eventos de la memoria episódica con una sensación de pasado, pero los actualizamos de tal manera que un recuerdo ocurre siempre en el tiempo presente» (Díaz 2011, 381). Se entiende por memoria episódica aquel «lugar» donde reposan los recuerdos:

Los recuerdos se almacenan en la memoria episódica incluyendo no sólo los contenidos manifiestos de contenido y lugar, sino también de tiempo, es decir lo que pasó, dónde pasó, cuánto duró y cuándo pasó. La memoria episódica registra los hechos o los contenidos junto con sus circunstancias espaciotemporales, como ocurre cuando las personas refieren el recuerdo de un evento impactante registrado con el sitio y las circunstancias (José Luis Díaz, 2011, 384).

Por lo tanto, la narrativa surte el efecto de actualizar y ajustar el relato a nuevas necesidades y deseos en la elaboración del lenguaje que cuenta la experiencia. Sin embargo, en la actualización y ajuste del relato es donde se confiere significado a la experiencia en el ahora. En palabras de Paul Ricoeur: «La narración re-significa lo que ya se ha pre-significado en el plano del obrar humano» ([1985a] 2004, 154).

Cuando María está contando su experiencia con la escucha de la salsa, en especial la música que produjo el sello Fania, recuerda las reuniones familiares que describe como su momento social más importante, pues realmente no es de muchos amigos y su familia es bastante numerosa. En dichos encuentros el factor determinante era escuchar 
esa música, cantar y, sobre todo, bailar. La música establecía el nexo que vinculaba el compartir, disfrutar, comunicarse y fortalecer los lazos de unión entre hermanos y sobrinos. En el transcurso del relato la evocación de la música está presente todo el tiempo y está asociada a muchos recuerdos familiares; entre ellos, el recuerdo de una hermana que ya no está. Pero el recuerdo trae consigo, también, ciertas cualidades de la persona a la que hace referencia; entre otras, su alegría. La asociación hermana - alegría - salsa es indisoluble, y así se manifestó en todo lo relacionado con este tercer personaje en el lapso de su narración:

Claro es que yo recuerdo hasta... cuando mi hermana... cómo estaba vestida, cómo se organizaba ella, porque mi hermana nació un 24 de diciembre. Y para ella los 24 de diciembre, pues eso era de foto, de estar muy elegante. [Risas] Para mi hermana el 24 de diciembre era muy especial. Entonces, ella llevaba... pues a ella le gustaba comprar los discos, nos llevaba [discos] y nosotros bailábamos eso entre hermanas y hermanos y pues esa era la fiesta. Entonces, yo recuerdo de ella, porque ella era una de mis hermanas mayores -ella era la segunda y ella era muy feliz-: [que] le fascinaba la música y entonces, yo, incluso cuando vimos la foto de mi hermana cuando ella cumplió como 20 años, sí lo recordaba, porque la foto era blanco y negro y yo recordaba a mi hermana ese día: qué color de vestido tenía, cómo estaba peinada... Ah sí, sí claro, [Risas] esas son cosas muy... y cómo le gustaba... me acuerdo como bailaba ella. [¿Sí? ¿Bailan muy diferente entre ustedes?] Sí, sí claro, cada una tiene un, como dicen: un swing; un «tumbao». Sí. [Risas] (Rosas Salazar 2014(1985a) 2004.).

Adicionalmente, puede evidenciarse que en las posibilidades de re-creación y reproducción de la música, el oyente se pone en una situación performativa o de performance; asunto que abordaré más adelante. Quizás, ambas acciones sean unas fotocopias peculiares y personalizadas del «objeto de la estética» en su literalidad. Pero también en la re-creación y en la reproducción de la música lejos de la exposición al sonido físico, la música puede vivenciarse con la misma magnitud que se alcanzaría si se estuviera expuesto ante el objeto literal.

El relato de María demuestra que la narración cohesiona su historia personal y, además, que la música cohesiona esta narración dada su condición constitutiva de la identidad individual y grupal. Ricoeur asume la identidad como una categoría práctica que en la narración sustenta la temporalidad de su estructura, a lo que agrega: 
El sí-mismo puede así decirse refigurado por la aplicación reflexiva de las configuraciones narrativas. A diferencia de la identidad abstracta de lo Mismo, la identidad narrativa, constitutiva de la ipseidad, puede incluir el cambio, la mutabilidad, en la cohesión de una vida ([1985b] 2004, 998). ${ }^{131}$

Esto para entender la forma en que la narración cohesiona una historia personal pero, además, para evidenciar la intervención de la música en la cohesión. Ricoeur plantea el problema de entender el tiempo como un flujo único y continuo; es decir, una sola forma de tiempo, sin fragmentaciones de ningún tipo, en la cual a una vivencia particular le corresponde una situación temporal «independientemente de su grado de alejamiento del presente vivo». ${ }^{132}$ Anuncia, entonces, que:

La dificultad a la que se trata de responder resulta de la necesidad de reconocer a los recuerdos de cualquier naturaleza un lugar fijo en el flujo unitario del tiempo, además del creciente alejamiento de los contenidos, que deriva del descenso que hace que estos contenidos se hundan en un pasado cada vez más lejano y brumoso (Ricoeur [1985b] 2009, 1006).

La música responde a tal planteamiento en cuanto ayuda a fijar ciertos detalles de la historia y a dinamizar otros. Por mencionar alguno: la asociación del carácter feliz de la hermana con la fascinación que sentía por la música; conexión que prácticamente se vuelve inseparable en el relato de María. Pero, detalles más leves o decorativos del relato se van reelaborando en la medida en que se cuenta, verbi gratia el desarrollo de las fiestas: quién bailaba, el swing que tenía cada hermano, entre otros.

Al mismo tiempo, el problema del alejamiento de la vivencia con el presente vivo, que socava el detalle de los contenidos de la experiencia, es resuelto en una medida considerable cuando el contenido está articulado con la música. Esto se aprecia con claridad en el relato anterior y a continuación con el de Ricardo. Con respecto a este último es necesario precisar, además, que el ajuste de la narrativa en el ahora evidencia a la vez la actualización de la información sobre el evento, la cual se refleja también en

\footnotetext{
${ }^{131}$ Ricoeur diferencia el sentido de la identidad atribuida a un mismo (ídem) conectada a una «ilusión sustancialista» de la identidad atribuida a un sí-mismo (ipse) cuya estructura temporal es, en consecuencia, dinámica.

${ }^{132}$ Esta dificultad es expuesta por Ricoeur en «La segunda aporía de la temporalidad: totalidad y totalización». Desde la paradoja de Kant, que indica que «el tiempo no transcurre», esta aporía refleja el problema del encadenamiento del tiempo en tanto éste es considerado con un carácter único y unitario; Así, no habría diferentes formas de temporalidad sino una sola, pero entendida como «la autoconstitución del tiempo como flujo único».
} 
el lenguaje que describe; es decir, en el lenguaje que se ha ido enriqueciendo con el conocimiento y la vivencia y que completa los datos para elaborar una descripción más asertiva de la experiencia. Ricardo, otra de mis fuentes, escuchó la primera canción de salsa cuando era niño. Actualmente, a sus 47 años, relata con «precisión» los datos del evento: «La primera salsa la escuché en la casa de un amigo. Yo muy pequeño, once años,... me llevó mi hermano, mayor de mí un año, y colocaron un tema que se llama «La peregrina» de Ricardo “Richie” Ray y Bobby Cruz» (Bernal 2015, comunicación personal). Además utiliza en el lenguaje vocablos que actualmente son propios del argot salsero:

[...] entonces ya me iba acercando yo a las personas que sacaban sus bafles a las puertas de la casa, que son ¡muy pocos! y yo me acercaba como un niño. Entonces: ¿te gusta? no sé qué, si sé más, y empezaban a colocar. Entonces, yo un domingo en vez de estar jugando a caballitos o ponchaos, estaba era escuchando «melodía» y ahí me fui «documentando.

En esta situación la palabra «melodía» obedece a una elaboración empírica del término empleada, sobre todo, por los escuchas expertos en la historia de la salsa. En el epígrafe 3.4 se anotaba el desarrollo que tiene el término y sus diversas acepciones semánticas. En la descripción de Ricardo, la connotación del término alude al género musical y está estrictamente relacionada con todo el conocimiento que un coleccionista, o buen melómano, debe tener en términos históricos al respecto de una pieza o una producción discográfica.

Aunque las teorías psicológicas y fenomenológicas adviertan que «la recuperación de un recuerdo implica siempre una representación críticamente actualizada entre obstáculos de edición consecutiva, olvido, tergiversación y falsos recuerdos» (Díaz 2011, 384), el recuerdo musical, o asociado a la música, es un acercamiento sensible y sentimental. En el caso de la salsa encuentro que a menudo está referido a ese deseo de revivir la emoción de la felicidad. Por supuesto, no es tan solo el carácter del género el que define la calidad de la experiencia; es decir, la energía y el frenetismo del ritmo salsero o la cadencia de las músicas caribeñas no van a remitir estrictamente a la alegría si la música fue vivenciada en un contexto adverso. En tal caso, el sonido sería una seña hostil al estar imbuido en dicho contexto y por lo tanto subordinado a él. Aquí, este tipo 
de música categóricamente «alegre» concitaría una reconstrucción de memoria necesariamente trágica.

En consecuencia, aunque la salsa y las músicas caribeñas se consideren categóricamente alegres, ello no implica que no existan tal tipo de construcciones con el género, ya que la salsa, entre otras temáticas, en su estilo abordó también la tristeza y el despecho, por mencionar algunas. Sin embargo, como referí en el subcapítulo 3.1 «Música caribeña, tropical y salsa: la realización de la felicidad», se presentaba la desconfiguración de la emocionalidad negativa para ser sustituida por la positiva; la cual podía ser una operación consciente o inconsciente en el oyente salsero. El bolero-canción tiene literariamente dos objetos: el idílico comienzo del amor o el fatídico final. Temas de salsa como «Triste y vacía» ${ }^{133}$ ilustran la realidad de la mentira y la traición; o «Las tumbas» ${ }^{134}$ expresa la vivencia nefasta del encierro en las cárceles. En el capítulo siguiente se tratará el testimonio de Alexa sobre una reconstrucción de experiencia trágica. Ella sufrió un desengaño amoroso que trastocó su vida en la juventud y pasaron algunos años para que pudiera recuperarse. La canción «Triste y vacía» se convirtió en aquel momento en el emblema de su tragedia. En los casi tres años que transcurrieron para su recuperación, escucharla la sumía en una profunda tristeza. Se sentía tan identificada con el tema que no podía desprenderse de él. Después de este periodo logró divorciarse de la canción; ya no se sentía perseguida por ella, pero si la escuchaba se ponía triste. Por último, y después de haber transcurrido mucho tiempo, Alexa considera que la canción no la afecta y puede disfrutarla en lugar de sufrirla. De hecho, cuando se remite a lo acaecido en aquel momento, tampoco siente que aquello la afecte. ${ }^{135}$

A su vez, el desplazamiento espacio-temporal de la música se evidencia rápidamente cuando el salsero reproduce corporalmente las melodías, textos y/o timbres de los instrumentos. El salsero baila, canta, tararea, percute e imita de manera onomatopéyica los golpes de la percusión o las líneas de los metales, en especial del trombón y la

\footnotetext{
133 «Triste y vacía» es una canción compuesta por Luis López Cabán e interpretada por Héctor Lavoe. Forma parte del álbum Vigilante de 1983 producido por Willie Colón. El tema se encuentra disponible en https://www.youtube.com/watch?v=rRHbB8jjU8c.

134 «Las tumbas» es un tema interpretado por Ismael Rivera «Maelo», reconocido en su campo como «El sonero mayor». Compuesto por Bobby Capó, está inspirado en los cuatro años de prisión que Rivera tuvo que cumplir en un reclusorio de Kentucky en los años sesenta. Disponible en https://www.youtube.com/watch?v=LbN2azLxRYE\&list=RDt9gsjztx3f8.

${ }^{135}$ Alexa no permitió que se registrara la entrevista por lo cual la narro resumidamente y reconstruyo algunos de los pasajes que utilizo en ciertas partes. Igual que María, sus nombres tampoco son reales, aunque esta última sí me permitió hacer un registro grabado.
} 
trompeta. ${ }^{136}$ Se vale ahí también del archivo sonoro o cancionero que tiene en su memoria para traer la música y elaborar una representación física del sonido; para materializarla cuando está ausente en el entorno natural o tangible. Luz Estela (2014, comunicación personal), maestra de escuela y profesora de tango, amante de la salsa, refiere dos experiencias recurrentes en su cotidianidad sobre la recreación y reproducción de la salsa:

¿Bailar salsa? ¡Todos los días! Cuando llego a la casa después de enseñar. Bailar y cantar salsa siempre, y si es posible: ipercutir! con mi cuerpo, o si tengo algunas claves o caja a la mano. [A lo que agrega:] Cuando me despierto siempre me levanto con un disco [tema o canción] de salsa en la cabeza (Barreiro 2014, comunicación personal).

Podemos notar que la reproducción corporal de la música es una evidencia contundente de la conexión del interior y el exterior de un individuo, de la conexión mente-cuerpo. El cuerpo y las acciones que encarna son una expansión del proceso mental, por lo que ambas conforman una unidad indisoluble. En sus reflexiones sobre música, mente y cuerpo Rubén López-Cano aborda las teorías de la mente extendida y subraya que la acción es una consecuencia inserta en una múltiple malla de conexiones, lo cual produce como resultado un «continuo indivisible». En éste, conocimiento, procesos, entorno y posibilidades físicas se confabulan para facultar la acción:

De este modo podemos concluir que entre el conocimiento que poseo para realizar una acción, los procesos neurofisiológico-cognitivos que la planifican y coordinan su ejecución, la configuración de nuestro cuerpo para hacerla, y las posibilidades que ofrece el espacio para realizarla, hay un continuo, una articulación compleja. El conocimiento no se agota en lo que sé, sino que lo que sé integra en lo que puedo hacer dentro de las constricciones que me impone el entorno. Y estas constricciones no le son ajenas, forman parte de mi conocimiento, de mi capital cognitivo. Mente y entorno (y mi cuerpo dentro de él) son codeterminantes, interdependientes. En el momento de la acción, unos penetran en otros hasta producir un continuo indivisible (López Cano 2013b, 51).

Estas reflexiones ayudan a explicar, igualmente, la operatoria performativa en los oyentes. Una manifestación muy usual de ella es la reproducción de las canciones; los

\footnotetext{
${ }^{136}$ En el siguiente capítulo, en el epígrafe «4.5 Personajes del barrio y representación. La decepción de Sofía», esbozo una muestra de este tipo de reproducción corporal de la música: en dicho caso, la melodía del trombón de la canción «Triste y vacía» realizada por una de mis informantes.
} 
melómanos cantan sus temas con el disco de fondo o sin él. Eso no implica que la recreación y la reproducción sean dos procesos desarticulados. Normalmente, el primero puede desarticularse del segundo; entonces solo se recuerda la canción y ésta ocurre en la memoria como un evento episódico más. Por el contrario, el proceso de reproducción de la salsa necesariamente está articulado al de re-creación, pues para encarnar la música y reproducirla corporalmente, es necesario estar conectado con el sonido. En el proceso de reproducción el sonido puede estar sucediendo interiormente en la memoria o estar transcurriendo en el mundo físico. Entonces, el cuerpo elige lo que va a re-crear o a reproducir; por lo tanto, refiero el cuerpo considerándolo la consciencia preclara de sí mismo, puesto que la reproducción que hace el salsero es inmediata. De repente, percute, imita el golpe de los bongós, imita el trombón, silva, canta, danza y pregona. Sí, pregona. El oyente más avezado pregona las rimas que fijó el intérprete en determinada grabación o improvisa las suyas propias. López-Cano señala que los gestos son interpretantes de la percepción musical narrativo-gestual, por lo cual «Durante la escucha musical proyectamos imaginación cinética. Nos movemos virtualmente con el fluir sonoro convirtiéndolo en una suerte de manifestación físicoperceptual de una competencia o imaginación motora tácita» (López Cano 2013b, 54).

En consecuencia, es muy usual observar que las palmas o el chasquido de los dedos marcan la clave de una canción, o que en el transcurso de una pieza el oyente mueve los hombros o las caderas, o hasta realiza algún paso de baile. Son casos de apropiación corporal de lo musical donde el sujeto adapta a sus posibilidades la música que vive en su memoria para desarrollar performances personales plenas de significado para él. Por ejemplo, para Gerardo, periodista y chef, la salsa es una parte más de la existencia. Cuando necesita escucharla y no la tiene en algún formato grabado, la reproduce a través del canto. En su trabajo es vital:

Cuando estoy trabajando tengo una canción metida en la cabeza, siempre si estoy trabajando, me da mucha energía, del buen rollo de la alegría, cuando estoy trabajando es un sentimiento muy agradable, para mí es una compañía muy importante (Benavides Martínez 2014, comunicación personal).

María Teresa es secretaria en una orquesta de música clásica de la ciudad. Habitualmente escucha música mientras desempeña algunas labores propias de su oficina. Sus preferencias salseras se inclinan hacia la producción de Fania y nunca le 
faltan las canciones de Héctor Lavoe. ${ }^{137}$ No le es posible utilizar audífonos mientras desempeña sus labores, por lo tanto la música siempre está a un volumen moderado. Sin embargo, no todo el tiempo que pasa en la oficina es propicio para reproducir música. Muchas veces en el lapso de espera (y de desesperación también) o en la antesala a su concierto personal, empieza a percutir sobre su escritorio algunos patrones rítmicos del género con los dedos o con su bolígrafo. De forma similar ocurre con Gerardo, mientras está en su cocina, repentinamente lanza algún paso de baile en tanto alcanza un ingrediente o un utensilio de preparación de la receta que vaya a preparar. Casi siempre canta un estribillo o coro de un tema. Indiscutiblemente, todo el cuadro es el preludio del concierto que tendrá curso inmediatamente establezca la primera fase de preparación de su fórmula gastronómica. Luego se dirige a su equipo de sonido y comienza el concierto. Entonces, continúa sus labores con normalidad. Como es de esperarse, el baile y el canto continúan mientras sea posible.

Los ejemplos anteriores son una breve muestra que verifica la reproducción del sonido salsero cuando física o materialmente está ausente o cuando «aún» está ausente, es decir, cuando el oyente tiene la intención de colocar un disco después de un momento. La salsa se re-crea y se reproduce en el oyente constantemente; la práctica de escucha del salsero va más allá de la percepción del oído biológico: es una escucha corporal que implica todas y cada una de las partes del cuerpo. Como muestran los ejemplos, la reproducción de la salsa no implica que el sonido original de la grabación esté transcurriendo físicamente, pues el melómano tiene un archivo interior del cual extrae la información sonora necesaria para dar curso a una realización corporal de la música. DeNora utiliza el término ‘get into action' para explicar la forma en que la música entra en acción o se pone en acción para organizar a los sujetos en tiempo real (2000, 8). Su get into action apunta a la manera en la cual una actividad física se coordina sincrónicamente con el ritmo de la música. Es importante anotar que esta sincronía puede ser consciente o semi-inconsciente y a ella se circunscribe la reacción corporal. DeNora precisa que el ejemplo más concomitante es el de la marcha, en la cual el pulso es cuadrado y perfectamente perceptible. Al respecto señala:

Musicalmente acoplado, el cuerpo y sus procesos se desarrollan en relación con los elementos musicales (en estos ejemplos, su pulso regular), que están alineados y

\footnotetext{
${ }^{137}$ Observé esta situación mientras trabajaba como músico para un programa de formación que tenía la misma orquesta, por lo cual frecuenté la secretaría con cierta asiduidad a lo largo del año 2015.
} 
regularizadas en relación con la música; están musicalmente organizados, musicalmente 'compuestos'. En la danza puede encontrarse una complejidad más amplia, pues el cuerpo no sólo es acoplado rítmicamente (el 1-2-3 del vals, por ejemplo) sino que también participa en maniobras estilísticas orientadas en la música (los puños apretados en relación con algo del rock o del pop, el ángulo del cuello y la barbilla en el ballet o la pelvis durante el cha-cha-cha). Esta alineación, entre la música y el cuerpo, a menudo ocurre subconscientemente o inconscientemente y puede conllevar micro-movimientos normalmente imperceptibles, por ejemplo en las cejas, en los pómulos, en los hombros o la tensión en alguno de los músculos $(2000,78) .{ }^{138}$

En concordancia con la reflexión de DeNora, la reproducción de la música que se describe en los ejemplos de Margarita y Gerardo organiza o alinea en tiempo real a los oyentes; tiempo real que está mesurado por las condiciones particulares de cada sujeto en determinada circunstancia. En los casos citados observamos que cuando el salsero reproduce corporalmente un ritmo o una melodía no tiene una guía material sobre la cual poner en marcha su ejecución; no es llevado por la música que esté transcurriendo físicamente. Por el contrario, son los oyentes quienes interior o subjetivamente definen los parámetros de medida del sonido que está sucediendo; parámetros de medida temporal y de altura del sonido en términos de entonación cuando se trata de una melodía. En este orden de ideas, las observaciones de mis dos informantes concuerdan con las de DeNora en cuanto a que son «realineados» o «acoplados» mientras exteriorizan un ritmo o una melodía con parámetros interiores que no son percibidos o experimentados por un tercero.

Por consiguiente, la música que se reproduce a instancias únicamente subjetivas o interiores del melómano (es decir, a instancias de lo que retiene en su memoria) es reproducida autónomamente y está ajustada a las posibilidades o capacidades de exteriorización o materialización del sonido que tenga el oyente. En consecuencia, no es extraño que un melómano cante en una tonalidad diferente a la original o ralentice o acelere el ritmo de una canción. Al poseer el recuerdo del tema original, el oyente puede

\footnotetext{
138 «Musically entrained, the body and its processes unfold in relation to musical elements (in these examples, its regular pulse); they are aligned and regularized in relation to music, they are musically organized, musically 'composed'. A more complexex ample can be found in dance, where the body is not only entrained rhythmically (the 1-2-3 of the waltz, for example) but also engages in stylistic manoeuvres in orientation to the music (the clenched fists in relation to some rock or pop music, the angle of the neck and chin in ballet, or the pelvis during the cha-cha-cha). This alignment, between music and body, often occurs subconsciously or unconsciously and it may entail normally imperceptible micromovements, such as how one holds one's eyebrows, cheekbones or shoulders, the tension of one's muscles».
} 
tratar de imitar su recuerdo, o puede dar rienda suelta a la apropiación personal que ha hecho del tema realizando performances que siguen, no la «partitura original» plasmada en lo que exactamente acontece en la grabación, sino apegándose al impulso emocional de lo que el sujeto ha construido en su cuerpo y mente de la experiencia de esa canción.

Paso a la siguiente observación: Daniela se pone a curiosear un teléfono móvil mientras canta «Ausencia», famoso bolero-son interpretado por Héctor Lavoe. ${ }^{139}$ (Puede escucharse en https://www.youtube.com/watch?v=93xwK9YNnC4). La tesitura de este cantante es bastante extensa: en este bolero baja tranquilamente hasta un Do del segundo espacio en clave de Fa y sube perfectamente hasta un La bemol del segundo espacio en clave de sol. La casual cantante tiene un registro de soprano, por lo que abordar una tesitura de tenor a la octava superior ya es difícil, ante todo cuando el registro de Lavoe es tan amplio, por lo que la transposición de las notas más agudas se dificulta sobremanera. Además, las notas graves son muy bajas para que una aficionada las cante con afinación aceptable. Ella supera tal dificultad estableciendo notas diferentes, aunque es relativamente afinada, y también incorporando otra colocación de la voz pero a muy bajo volumen. En cuanto al tempo de su interpretación, en concordancia con el género es lento, pero ella lo establece un poco más lento en comparación al del bolero-son original del tema. En este punto se observa cómo el receptor aprovecha los elementos musicales a los que tiene acceso para reproducir exteriormente la música que tiene almacenada en su interior.

Hay un aspecto que igualmente concierne a la re-producción musical, aunque en un caso más especializado: cuando el oyente tiene la información y las competencias suficientes para traducir en salsa estilos musicales diferentes. Es decir, otros tipos de música u otros textos son traducidos técnica o intuitivamente al lenguaje musical de la salsa: «La música ha estado en mi familia desde siempre. Toco y acompaño salsa en la guitarra, y lo que no sea salsa, lo convierto en salsa» (García 2014). En efecto Jorge García, quien me brindó este testimonio, es músico y conoce de lleno el lenguaje musical del son y

\footnotetext{
139 Observación casual realizada en julio de 2015 y de la cual pude registrar parte de la canción. Luego de intercambiar un par de apreciaciones sobre el hecho, Daniela manifestó su deseo de poner la música real y rápidamente fue en su búsqueda. Cuando le pregunté el porqué de su elección su respuesta inmediata fue «no sé, se me vino a la cabeza». Después expresó su gusto por la letra de la canción y la lírica con la que está construidas la historia de la misma; por ejemplo sugirió la siguiente frase: «yo vi llorar a un hombre ante un espejo por un amor que le negara el cielo, y asombrado me dio un escalofrío al ver en el espejo el rostro mío...»
} 
otras músicas caribeñas o latinoamericanas. Jorge elige algunos trozos de melodías de baladas o canciones para niños y los versiona fácilmente en bolero-son o bossa-nova. ${ }^{140}$

Lo anterior nos brinda parámetros para aproximar el grado de apropiación de la música del melómano salsero en términos de su re-creación o su reproducción. Los dos procesos son posibles gracias al desplazamiento que la música puede hacer y que se opera en la memoria personal de cada individuo. La capacidad de reproducir corporalmente una canción en sus diversos elementos, no sólo estructurales (melodía, ritmo), sino de arreglos (instrumentación) y aún de las propiedades de una grabación (ecualización, reverb, entre otros) es otra forma de apropiarse de la música, de hacerla suya adaptándola a las necesidades expresivas del oyente, desde las posibilidades que posea en términos de capacidades performativas o conocimiento del género.

Con lo cual, vemos que en la salsa el cuerpo es vital en la agencia de mundos de sentido; por supuesto en cualquier música lo es, pero esa disposición de la salsa a ser un género bailable sintoniza una relación directa entre escucha y movimiento corporal y vincula emociones referentes al goce y a la alegría. De esta manera, en el despliegue corporal, en la performance, el cuerpo es dirigido a esa realización. En otras palabras, el cuerpo siente pero a la vez, de alguna forma, reflexiona y actúa; de ahí que en las vivencias de mis entrevistados más de uno recordase cómo fue sorprendido con la salsa mientras su cuerpo se ponía en movimiento o bailaba sin tener, racionalmente, previo conocimiento del estilo y sin saber por qué estaba haciendo eso: moverse al son o al ritmo de una música desconocida en ese instante. ${ }^{141}$ Estas reflexiones suscitadas a partir de la oralidad de mis informantes, mi visión de su cuerpo y la percepción que ellos mismos tienen sobre su cuerpo en la salsa, enriquecen la perspectiva del cuerpo en estrecha conexión con la mente. Materia a la que se han acercado diversas teorías y han ayudado a subsanar la errónea convicción de que mente y cuerpo son dos entidades

\footnotetext{
${ }^{140}$ Tal cual observaba en la sección 2.4 La especial cronología de escucha en el país, acerca de la salsa asumida como género y, al mismo tiempo, como un encuadre histórico-cultural, Jorge García, toca el fragmento en ritmo de bossa-nova sin pensar siquiera en si es salsa o no. Pero, consecuentemente, con la apreciación de Ismael Carreño, su gesto condice que todos los estilos populares urbanos de aquella época, se consideran salsa para algunos expertos del campo.

${ }^{141}$ Testimonios citados anteriormente como el de Wilson Córdoba acerca de la sorpresa con la «respuesta de su cuerpo al ritmo, sobre todo al sonido de los tambores», o de Ricardo Bernal cuando él mismo y su madre quedaron «aterrados» por la conducta corporal de su cuerpo ante el sonido, dan fe de la manera en que responde el cuerpo cuando escucha salsa. Es una respuesta que sin previo aviso a la dimensión consciente de una persona, apremia por un desenvolvimiento rítmico, por una especie de resolución en el movimiento.
} 
diferentes o, al menos, desligadas; incluso, en ocasiones, dominada una por la otra debido a la concepción racionalista del pensamiento.

Por último, conviene señalar que en el recorrido de este capítulo gran parte de los testimonios presentados guardan una estrecha vinculación con procesos identitarios; en algunos casos el mismo melómano afirma que en la salsa se constituye su identidad, o algo de ella. En otros casos la referencia a la identidad o a la identificación no es directa ni se verbaliza, mas se nota su presencia tácita en las narraciones de las historias de vida. En concordancia con Paul Ricoeur, se evidencia la practicidad de la identidad desde el propio relato del narrador; relato que señala el quién y el qué de una vida y define que la «la propia identidad del quién no es más que una identidad narrativa» ([1985b] 2009, 997). Tanto el agente y la acción de narrar como la temporalidad que le es inherente a cada uno, son los factores que en definitiva confieren el sentido dinámico a la noción de identidad. En efecto, los melómanos miran en retrospectiva su vida conformada por las historias sobre la salsa y las calles, la rumba en las discotecas, la experiencia corporal, la vivencia familiar, la socialidad en el conseguir y compartir los acetatos y luego copiar, por ejemplo. La narración de la historia es, claramente, organizada en el momento de la verbalización. Tal sentido dinámico de la identidad, de la identidad narrativa, es el que se considera un problema en la era postmoderna al develar la inestabilidad del sujeto; un sujeto «descentrado» que ha puesto en «crisis» los sistemas de significación, como mencionaba anteriormente.

Pero desde otro punto de vista, en esta crisis de los sistemas de identificación se allana el camino para entender la identidad como una «experiencia»; pues es inevitable asumir que hoy el sujeto está expuesto a un flujo constante de referentes culturales que fragmentan su subjetividad, por lo cual se hace necesario encontrar un tejido unificador que dé coherencia a las identidades fragmentarias que constituyen a cada persona. Es aquí donde la narrativa actúa como el eje que acopla ese vaivén de experiencias que son la historia de vida de los individuos o de los grupos y donde la música tiene un rol preponderante. 


\section{CAPÍTULO IV. SUBJETIVIDAD Y PERFORMATIVIDAD DEL «YO»: QUIÉN SE ES EN LA ESCUCHA DE LA SALSA}

En este capítulo se contempla la producción de subjetividad mediada por la escucha musical. Para ello se consideran trascendentales los mecanismos de identificación y de identidad que son integrados en la operatoria performativa. En ambos mecanismos es vital la función que cumplen las interpelaciones del género salsero y la forma en que se articulan en el momento estésico de los oyentes y en otras experiencias de significado. Bajo estos principios se estudiará la performatividad del «yo» en la escucha de la salsa, incluyendo algunas de las interpelaciones más recurrentes del género en sus melómanos. Si bien son reiteradas y, en cierta forma, naturales las relacionadas con el ritmo frenético y el compás cadencioso de la salsa o las músicas caribeñas, deben estimarse las elocuentes interpelaciones de la vocalidad y la historia de los intérpretes, las líricas callejeras y su representación del barrio y de los sentimientos de la gente común y, por último, el entramado músico-instrumental denominado en argot salsero: «melodía».

A partir de este derrotero en la sección «Vocalidad: identificación y representación» hago un acercamiento al ensayo de Roland Barthes «El grano de la voz», cuyo empleo de los conceptos feno-texto y geno-texto es una explicación prometedora a la sujeción que producen las voces, dirigiéndome al final a una aplicación de ambas expresiones en la vocalidad de la cantante cubana La Lupe. Enseguida, relaciono ciertos vocablos utilizados por mis informantes referidos a la elaboración del concepto «verdad en la voz». Después, me fijo en la imagen de algunos cantantes cimentada desde su vida personal y pública para comprender cómo las audiencias «apropian las historias personales» y crean nexos identificatorios; expongo los casos de Frankie Dante y Héctor Lavoe. Luego incursiono en la «lírica del lenguaje callejero» constatando la carga de representatividad de la gente común y del barrio contenida en los textos salseros. Posteriormente, en «la decepción de Sofía» uno de los personajes icónicos de las letras de Lavoe, reviso la asunción de la adversidad en el género. Finalmente, analizo la mediación de la salsa en la construcción de un cuerpo que es capaz de organizar la realidad y que se atribuye el poder necesario para agenciar el caos o el sentido en una ciudad difícil de transitar. 
Para continuar es justo esclarecer que la performatividad que interesa a esta tesis no es la que se alberga en la ejecución o la interpretación musical; la del intérprete o el compositor, sino la del oyente receptor. Por lo tanto, se comprenderá aquello que la performatividad ayuda a lograr en el sujeto de la escucha. ${ }^{142}$ Según Austin ([1962] 1991) la acción performativa del lenguaje acusa una realización física, sensible o corporal a la hora de su enunciación. Irrefutablemente en la escucha, la música ostenta y despliega dicha propiedad. En el melómano salsero se evidencian fácilmente los actos performativos, más cuando la salsa en su calidad de música bailable conlleva a tantas realizaciones corporales. El baile o el canto, o tan solo la escucha, y en sí la emocionalidad que genera el goce de la salsa, inducen en el oyente una especie de metamorfosis corporal y mental que lo convierte en ese «otro» imaginado y deseado o, posiblemente, insospechado. Por tal motivo, en la cuestión de la performatividad del «yo» sobreviene la inevitable pregunta sobre la música en la identidad personal, que Frith responde por medio de las siguientes consideraciones: «primero, que la identidad es móvil, un proceso y no una cosa, un devenir y no un ser; segundo, que la mejor manera de entender nuestra experiencia de la música — de la composición musical y de la escucha musical - es verla como una experiencia de este yo en construcción» (Frith 1996, 184).

Pero no se puede descartar que a la performance le sea inherente la carga simbólica que acarrea la música. En la salsa las representaciones reiteradas del universo caribe y urbano latinoamericano, por ejemplo, han contribuido en medida importante a que el mismo oyente construya una definición de sí e identifique su entorno gracias a los parámetros que indica la música. Uno de mis entrevistados afirma: «[a través de la salsa] entendí lo que era "ser latino” y desde allí empecé a reconocerme como latino, entonces comencé a ir a La 19 a buscar el sonido» (Córdoba 2014, comunicación personal). Hay que remitir la capacidad que tiene la salsa para abordar y elaborar los escenarios del mundo urbano latinoamericano. La salsa escudriña desde el rincón más escondido de la casa hasta el recoveco más recóndito de la calle, y cruza por las emociones más joviales y efímeras de la gente hasta los sentimientos más profundos y

\footnotetext{
${ }^{142}$ A propósito de la incursión de los estudios sobre performatividad en el campo de la investigación en música, Alejandro Madrid nos ofrece la siguiente reflexión: «Tomando la definición de Austin como eje de su búsqueda intelectual, los estudios de performance como campo se preguntan no qué son las acciones, eventos o manifestaciones culturales que estudia, sino qué es lo que éstas hacen. Los estudios de performance no buscan describir acciones para ser reproducidas con fidelidad después; en lugar de eso tratan de entender qué es lo que dichas acciones hacen en el campo cultural en las que se dan y qué les permiten hacer a la gente hacer [sic] en su vida cotidiana» (Madrid 2009, 3).
} 
aterradores de los seres humanos. A la narrativa salsera, por supuesto, se suma la de la música cubana y, en general, la del eje Caribe que presenta diferentes desarrollos en concordancia con los procesos históricos de cada lugar.

\subsection{Vocalidad: identificación y representación}

Las canciones de la salsa retratan historias y personajes anónimos que son familiares o comunes en los barrios de la ciudad. Cuando el personaje retratado es tan lejano con respecto a lo que el oyente podría imaginar de sí mismo, la voz del intérprete encauza la realización de ese «otro» en el yo presente que escucha. Para algunos salseros la vocalidad de los intérpretes es definitiva en la experiencia de encarnación o realización de aquel otro; es el puente que permite al oyente investirse del personaje en el transcurso de la música. Pero también los personajes y temas que se ilustran en la salsa son representaciones del habitante normal de la ciudad o del pueblo; del que transita cotidianamente los espacios de la casa o las calles del barrio; del transeúnte de la gran urbe, del oyente promedio. En este sentido, el intérprete habla o dice lo que el oyente quiere decir; incluso representa lo que el oyente quiere ser o tener. De esta forma, en el juego representacional la voz del cantante es una de las interpelaciones más potentes y constituye uno de los mecanismos de identificación más fuertes. Frith resuelve que en el siglo XX la música popular enfoca más la voz, a lo que argumenta:

Es precisamente con la música vocal con la que establecemos una mayor conexión, con la que mejor podemos apropiarnos en cierto modo de las interpretaciones. La personalidad de los ídolos de la música popular se construye a partir de la voz (y, al menos desde la segunda Guerra Mundial, los más famosos han sido cantantes). El timbre de la voz es más importante en este contexto que la articulación concreta de un contenido textual determinado, y ello implica, por ejemplo, que grupos como los Beatles puedan asumir una voz de conjunto. Podemos identificarnos con una canción tanto si entendemos el texto como si no, tanto si conocemos previamente al cantante como si no, porque es la voz -no el texto de la canción- lo que provoca nuestra reacción inmediata. Esta circunstancia nos lleva a plantearnos algunos interrogantes en torno a la música popular no-vocal, que podremos responder únicamente si asumimos la voz como un signo de personalidad individual y no tanto como algo que necesariamente articula palabras. La voz, por ejemplo, ha sido y es un elemento central en el atractivo del jazz, no por los vocalistas en sí mismos, sino por el modo en que en el jazz se tocan y 
escuchan los instrumentos: las voces instrumentales de Louis Armstrong o de Charlie Parker eran tan individuales y personales como la voz de cualquier estrella del pop (Frith [1987] 2008, 429).

Frith evidencia en la voz la conexión individual con la interpretación. Para los oyentes salseros el fenómeno de identificación con la voz define, en muchas ocasiones, las preferencias por determinados artistas, sin que se tenga en cuenta exactamente los textos o el significado de lo que canten, como acertadamente expresa el autor. Por eso Maelo, sin contar un éxito o hit musical en específico, es de la predilección de mi informante Alejandro (2014, comunicación personal), o Bobby Cruz es la gran preferencia de María (2014, comunicación personal). Hall aproxima una definición de «identificación» que viene muy al caso en la explicación de la identificación de los oyentes con sus intérpretes. Recurriendo al desarrollo psicoanalítico del término, afirma: «De su uso psicoanalítico, el concepto de identificación hereda un rico legado semántico. Freud lo llama "la primera expresión de un lazo emocional con otra persona"» y arguye que la identificación «se funda en la fantasía, la proyección y la idealización» $(1996 a, 16) .{ }^{143}$ Evidentemente, las voces de los intérpretes generan lazos emocionales en cada oyente, lo que posibilita la identificación con el intérprete y/o con el personaje retratado en la canción. La voz entendida más allá del timbre, el acento o cualquier otro elemento al que sea posible referirse, está integrada asimismo por elementos que aún no están nombrados en la lengua, los que determinan la conexión, el arrastre, el enganche, la interpelación en sí misma de una voz en un sujeto.

Usaré el término vocalidad para acercarme al análisis de las voces de la salsa y, aunque el timbre, el acento, la tesitura, el color y otros estén directamente relacionados con la voz en tanto producción corporal, he de remitirme a la categoría vocalidad para integrar dos aspectos que hasta el momento se han tratado tímidamente con amplitud o profundidad, y menos aún han sido abordados de manera técnica: la oralidad callejera y la trayectoria de la voz. No obstante, mi pretensión, lejos de aportar definiciones extensas o académicas sobre estos términos, es sugerir un camino para su construcción, en cierta medida, a partir de la elaboración empírica que han hecho los informantes de esta tesis. Considero que los aspectos mencionados en principio hacen referencia a la corporalidad de la voz y estos dos últimos a la corporeidad de la voz. Para aproximar

\footnotetext{
${ }^{143}$ Sobre identificación y vocalidad bajo los postulados psicoanalíticos, ver Freya Jarman-Ivens (2011) Queer Voices. Technologies, Vocalities, and the Musical Flaw.
} 
una definición de la oralidad callejera y de la trayectoria en la voz, haré una abierta aplicación de los conceptos abordados por Ramón Pelinski (2005) en «Corporeidad y Experiencia Musical» y los desarrollados por Pierre Bourdieu en sus Notas provisionales sobre la percepción social del cuerpo (1986), no sin antes recordar el ensayo de Roland Barthes ([]1982 1986) «El grano de la voz», en el cual encuentro gran afinidad entre los conceptos de grano y de vocalidad. Luego me acercaré a la noción de vocalidad propuesta por Paula Vilas (2005) para comprender el sentido de la producción corporal de la voz en su dimensión socio-histórico-cultural.

Barthes, en su estudio comparativo sobre el grano de la voz, hace uso de dos connotaciones vocales a partir de la transposición conceptual de fenotexto y genotexto de Julia Kristeva. El fenotexto serían las implicaciones del lenguaje desde la cultura misma de un autor, lo fenoménico, y para el lector sería la obra en sí misma que lee como resultado. El genotexto sería para el autor el proceso de la obra, mientras para el lector sería el producto de su lectura. Son dos factores que marchan inseparablemente unidos. Barthes transpone los términos a fenocanto y genocanto y define el primero como:

El feno-canto (suponiendo que se acepte esta trasposición) cubre todos los fenómenos, todos los rasgos que proceden de la estructura de la lengua cantada, de las leyes del género, de la forma codificada del melisma, del idiolecto del compositor, del estilo de la interpretación: en resumen, todo lo que, en la ejecución, está al servicio de la comunicación, la representación, la expresión: aquello de lo que normalmente se habla, lo que forma el tejido de los valores culturales (gustos confesados, modas, discursos críticos), lo que se articula directamente sobre las coartadas ideológicas de una época (la «subjetividad», la «expresividad», el «dramatismo», la «personalidad» de un artista) (Barthes [1982] 1986, 265).

Y para el genocanto define:

es el volumen de la voz que canta y que dice, el espacio en el que germinan las significaciones «desde el interior de la lengua y en su propia materialidad»; se trata de un juego significante ajeno a la comunicación, a la representación (de los sentimientos), a la expresión; ese extremo (o ese fondo) de la producción en que la melodía trabaja verdaderamente sobre la lengua, no en lo que dice, sino en la voluptuosidad de sus sonidos significantes, de sus letras: explora cómo la lengua trabaja y se identifica con 
ese trabajo. Se trata, dicho con una palabra muy simple pero que hay que tomarse en serio, de la dicción de la lengua» ([1982] 1986, 265).

Desde esta sistemática transposición, Barthes aplica su análisis a dos cantantes operáticos; el barítono alemán Dietrich Fischer-Dieskau y el barítono lírico francés Charles Panzéra. De Fischer-Dieskau comenta que los elementos del fenocanto son perfectos, pero «nada arrastra al placer»; «lo que en su caso acompaña al canto es el alma, no el cuerpo». Señala, además, que en la pedagogía del canto se enseña los modos emotivos de su emisión, el aliento, mas no el cultivo del grano. De esta manera, el grano se constituye en esa postura de la voz donde lengua y música se encuentran y, además, donde se experimenta el goce individual al escuchar cantar. Aquí nace un significado nuevo, lo que el autor llamaría significancia. ${ }^{144}$ Pero hay que advertir en este punto que esta reflexión es un ejemplo aislado de la interpelación de una voz determinada en un oyente específico. Sin embargo, es posible que la voz de FischerDieskau sí arrastre al placer a otro oyente debido a que ésa es, justamente, la complejidad de la «interpelación»: estar sujeta a la sutura de la «articulación»; condición que es absolutamente personal.

El contraste que se expone en el análisis constata la multitud de operaciones que cursan cuando una vocalidad conecta la subjetividad de un oyente y produce significación. ${ }^{145}$ Siguiendo su teoría, en la voz que posee el grano trascienden los significados normales y se produce la significancia. Significancia y grano que también se presentan en las músicas populares, como advierte el autor. En el énfasis que pone al encuentro de la lengua con la melodía se discierne un estimable aspecto, muy sensible en algunas músicas populares latinoamericanas: aunque su común denominador sea la lengua

\footnotetext{
${ }^{144}$ A través de una exégesis histórica de la escucha, el autor anuncia el quebrantamiento de «la Ley que prescribe una escucha correcta, única». Más que una escucha aplicada, la de hoy pide que deje surgir. Ya no es una escucha confesional en la que a un lado está el que habla y se confiesa y en el otro el que escucha y juzga, porque es activa y «se hace cargo del lugar que tiene que ocupar en el juego del deseo». Así, los dominios tradicionales de la escucha «la escucha arrogante del superior y la escucha servil del inferior» están desestabilizándose. Por lo tanto, lo que se escucha no es la llegada de un significado «sino la misma dispersión, el espejeo de los significantes nuevos, sin retener jamás el sentido: este fenómeno de espejeo se llama la significancia». (Barthes [1982] 1986, 255-56).

${ }^{145}$ Para el autor, que una vocalidad conecte la subjetividad de un oyente implica una función vital de la escucha. Así, identifica tres tipos de escucha. Oír es el fenómeno fisiológico en el cual «el ser vivo orienta su audición hacia los índices»; es una alerta. En el segundo tipo, lo que se capta ya son signos, entonces, hay un desciframiento de códigos. La tercera escucha no se relaciona con signos clasificados; «no se interesa en lo que se dice o se emite sino en quien habla». Según el autor, opera en un estadio intersubjetivo «en el que "yo escucho" también quiere decir "escúchame”». En esta escucha lo que se capta se transforma indefinidamente -transfert-; es una «"significancia” general, que no se puede concebir sin la determinación del inconsciente» (Barthes []1982 1986, 243-44).
} 
española, en cada región se distinguen unas variantes de pronunciación, color, timbre o cualquier otra característica que identifique la procedencia del acento. Es decir, de todo aquello de lo que se puede hablar: el feno-texto. Pero es menester mencionar que este aspecto tan sensible está demarcado por la modernidad. Bajo esta perspectiva, es crucial dirigirse a la manera en que se constituyeron los barrios latinoamericanos en el siglo XX. Cuando se habla de las músicas populares, muchas de ellas originadas en los entornos rurales, pero migradas, asentadas y transformadas en la ciudad, se verifica que el barrio fue el caldo de cultivo de la sonoridad de las músicas urbanas.

A partir de aquí retomo la noción de vocalidad utilizada por Paula Vilas. El trabajo de la investigadora, netamente etnográfico, se basa en el estudio de las voces afrodescendientes del quilombo ${ }^{146}$ de Pombal en el estado de Goiás, cerca de Brasilia. Este trabajo enfoca la vocalidad en las performances culturales tradicionales de las fiestas y juergas de Reyes y del Espíritu Santo. Vilas se fundamenta en la obra de Paul Zumthor, ${ }^{147}$ que aporta a la voz una dimensión de historicidad en el uso de un grupo determinado. Aquí la voz es entendida como «una producción del cuerpo capaz de producir sentidos complejos» (Vilas 2005, 189). En el marco de las fiestas, se distingue en el canto-rezo a dos voces de las rezanderas de Pombal un rezago colonialista en el rezo del rosario, que a través de la supresión de unos fonemas y la creación de otros, promueve lo recordable y vela lo que debe permanecer oculto. Surge desde allí una dimensión de estudio para «una escucha de la memoria “in-corporada” en la vocalidad en cuanto producción histórico social» ${ }^{148}$ (Vilas 2005, 195).

Tales consideraciones ayudan a definir el sentido histórico de las voces. Aunque el trabajo de Vilas se centra en las voces colectivas de un grupo afrobrasilero, hay que reconocer la construcción histórica en las vocalidades. Independientemente de que cada intérprete tenga la suya propia, hay un sesgo que caracteriza las voces desde lo histórico. Con respecto a la salsa, pese a que solo nos estamos refiriendo a la música popular del siglo XX en Latinoamérica y no a los siglos de vocalidad afroamericana, hemos de consensuar que ya se advierten ciertos matices. Si el barrio fuese una

\footnotetext{
${ }^{146}$ El quilombo es el equivalente en español de palenque; lugar físico en la selva especialmente, y lugar social en el que se asentaron los negros que huían de la esclavitud -cimarrones- y que se constituyeron en núcleos de resistencia y de nuevas sociedades afrodescendientes. En la actualidad, el quilombo de Pombal se auto-identifica como quilombo remanente o remanente de quilombo.

${ }^{147}$ Vilas cita la siguiente obra: Zumthor, Paul. A letra e a voz: a "literatura" medieval. São Paulo: Letras, 1993.

148 «a escuta da memória “in-corporada” da vocalidade enquanto produção histórico-social».
} 
metáfora de la vida, diríamos que tiene su propia corporeidad y es ésta la que instaura la identidad de determinadas músicas populares latinoamericanas. Por ejemplo, sería muy diferente escuchar el recitativo de la «Balada para un loco» con un acento que no sea argentino. Aunque no solo es cuestión de acento; como precisé antes, claramente intervienen factores como la voz de Roberto Goyeneche, que ha hecho una de las versiones más estridentes de la canción, o la melancolía que genera y se atribuye al tango, y sobre todo: esa manera de producir la voz callejeramente, como si de una conversación en la esquina del barrio se tratara. Con lo antedicho, lo que se presume es que todos estos factores están determinados por su origen, transformación, hibridación y dinamización en el barrio latinoamericano moderno. En este punto, no suene raro volver al asunto del cuerpo porque la corporeidad bebe directamente de la dinámica sociocultural del barrio y, por ende, la vocalidad es a su vez constitutiva de la corporeidad. De esto se deduce que en la voz hay una carga de vivencia de barrio; característica determinante de la vocalidad en ciertas músicas populares urbanas latinoamericanas.

Si nos detenemos un momento en el proceso histórico de la salsa es imprescindible para el análisis de la voz visibilizar aquella fractura o, mejor todavía, aquel conducto que permitió el tránsito entre el canto glamuroso del estilo cubano de los cincuenta ${ }^{149}$ y el canto descuidado y arrabalero proveniente de las calles del barrio, que empiezó a fraguarse en la Nueva York de los sesenta, como sostiene el estudioso César Miguel Rondón. De hecho, en la salsa neoyorquina ese componente sonoro que emana de las fricciones de la vida en El Barrio no solo queda plasmado en lo vocal sino también en lo instrumental. Rondón explica:

El lujo y la ostentación se desvanecieron por completo y en su lugar se instalaron la violencia y lo agrio de determinado tipo de vida: el del barrio marginal. En efecto, la calidad musical decayó, ya no existía la vigorosa sonoridad de la década anterior. Sin

\footnotetext{
${ }^{149}$ Para la década de los cincuenta la ciudad de La Habana se había convertido en uno de los centros con mayor vida nocturna de Latinoamérica y el Caribe. Con una significativa bonanza económica debida a la inversión norteamericana en la ciudad; destino de recreo y pasatiempo de los estadounidenses, en La Habana florecieron los casinos, las salas de baile, los cabarets, y con ellos las grandes y distinguidas agrupaciones musicales. Ya en la década de los cuarenta habían empezado a escucharse esporádicamente agrupaciones del corte de las bandas de jazz norteamericanas, de gran formato y armonías enriquecidas. Naturalmente, toda esta ostentación y glamour estaban lejos del barrio popular: «El Pérez Prado que logró éxito en México tuvo su primer público en las clases medias que sintieron su música suficientemente sofisticada y elevada. En Cuba, las orquestas avanzadas tampoco trabajaron en función del barrio. La Casino de la Playa, por ejemplo, considerablemente americanizada siempre actuó en los predios de "los blanquitos” animando con toda la sobriedad del caso sus fiestas y bailes» (Rondón [1978] 2007, 43).
} 
embargo, había mucha mayor autenticidad en lo que se cantaba. Los ruidos desesperados e hirientes del barrio se tradujeron en trombones que desafinaban y en montunos donde la violencia musical era el sello distintivo. No podía ser de otra manera, la vida en esa parte de la ciudad no era plácida, y la música que ahí se producía tampoco. Cantar el meloso cha cha chá cubano, por tanto, tenía poco sentido: la música de ninguna manera podía seguir siendo “delicada”, fina y elegante (Rondón [1978] 2007, 46-47).

De esta forma, las voces que serían de la salsa, provenientes de la tradición cubana, portorriqueña y antillana en general, empezaron a forjarse en una ruta autónoma que iba de la mano con los desarrollos musicales estadounidenses. En cierta manera, eran voces que se estaban actualizando en sintonía con lo que sucedía tanto en el barrio como en el ambiente musical norteamericano. Rondón asevera que fue necesario para la música latina en Nueva York que el son y demás aires cubanos o antillanos hicieran un maridaje con la modernidad musical estadounidense; una fusión con el pop.

Cuando Tito Puente salió en escena apoyando con su orquesta la voz de la Lupe, el ambiente se vio revolucionado. De alguna manera, se prolongaba la tradición cubana, la música seguía ostentando la fastuosidad característica, pero también se sentía el otro elemento, el del canto marginal, hiriente, algo descuidado, lleno de esas mañas y esos trucos que jamás soportó el ortodoxo del canto caribe. Con la Lupe, pues, el big-band (con toda la carga de significados que arrastraba) se aproximó al barrio. Y es que La Lupe surgió en el momento justo: ella, cantando diez años atrás las mismas cosas con el mismo estilo hubiera sido descartada por tratarse de una cantante gritona, desordenada y "falta de respeto" (así la definieron unos cuantos periodistas de farándula de la época). Sin embargo, La Lupe apareció cuando ya la pompa y el glamour habían caducado, cuando lo que mandaba era el barrio, que se impone con todas sus violencias e irreverencias. Y La Lupe, sin ubicarse plenamente en la salsa, bien pudo asumir muchas de sus características y virtudes. Entienda el lector que no se trataba de reparar en el show de La Lupe, en esos zapatos que le tiraba al público en aquel arbitrario strip-tease que, sin ser sexy, dejaba inconcluso en medio del montuno; se trataba, tan sólo, de captar su manera de decir la música, ese desorden feliz de guarachas, bombas, sones y boleros que produjo a manera de puente entre una época y otra (Rondón (1978) 2007, $62)$. 
El autor escribe acerca de la manera de «decir» la música de La Lupe, quien ha sido una de las cantantes más recordadas en mi grupo de informantes. ${ }^{150}$ Sin embargo, no ahonda en este aspecto central de la performance de la cantante: su voz y su dicción. Por cierto, ha sido bastante difícil encontrar referencias sobre este aspecto. Los análisis se dejan llevar por lo más llamativo; lo estrafalario, el movimiento corporal desordenado, lo incoherente de su figura. Las personas que la asistían en sus presentaciones cuentan que, generalmente, al terminar de cantar un tema estaba sin aliento y que muchas veces tuvo que recurrir a una bala de oxígeno detrás de bambalinas para reincorporarse al show. Todas estas descripciones de lo visible, al parecer, están también relacionadas con el carácter de la intérprete; son una prolongación de la desbordada personalidad de la cantante. Al observarla en algunas entrevistas se evidencian el desparpajo y la desobediencia a la norma de presentación ante el «otro», lo que refuerza la imagen con la que la construyeron estética y socialmente sus públicos.

Al centrar la atención en su canto fácilmente nos damos cuenta de la forma desgarrada y violenta de emitir la voz. Es patente el estallido de las palabras en la garganta, la dicción explosiva de las letras; parecería que se hiciera daño al emitir cada fonema. Mas este desgarre de la voz es una constante de su canto, está presente en toda la emisión vocal sin importar el registro melódico; es decir, toda la tesitura mantiene uniformemente esta característica. En cuanto a las dinámicas de volumen y los matices de intensidad, se diría que los fortes más enérgicos son más propicios al desgarre, pero en los pianos más leves se detecta también el efecto. Si nos vamos a los géneros que interpretó, desde la guaracha hasta el bolero y a su paso, el soul, el mambo, la balada y demás, el desgarre gutural es patente.

Un componente fundamentalmente distintivo de su estilo vocal es el recitado o hablado en medio de las frases y sobre todo al final. La intervención de su recitado es definitiva en el fraseo; atributo que permite que la interpretación se vaya construyendo como un diálogo directo con un interlocutor específico: el oyente individual en la intimidad de su espacio privado o el público en el concierto. Pareciera un intento de hablar en forma directa con alguien, con su público, aunque el tono puede aproximarse más al de una

\footnotetext{
${ }^{150}$ Cabe destacar que fue bastante mencionada en el grupo masculino. En el femenino no se la mencionó mucho y algunas entrevistadas manifestaron total desagrado con su performance en general. Cito un comentario: «La Lupe no me gusta mucho en términos vocales; sí era una mujer particular, tenía un estilo esquizofrénico y desgarrado para cantar. No es de mi agrado musical pero sé que tiene temas insignia y que marcó un estilo. Y lo que genera en mí la Lupe es como estrés, desespero... En la música latina se requiere equilibrio, disciplina» (Angarita 2014, comunicación personal).
} 
discusión, un reclamo o una sentencia y no siempre al de una conversación. ${ }^{151}$ Gerardo opina que «su estilo era muy teatral; una mezcla entre cantar y narrar, que para el tipo de canciones que interpretaba, iba muy bien» (Benavides Martínez 2014, comunicación personal). El musicólogo Helio Orovio afirma que:

Al descargar, al parlar, al hablar, era una especie como de rapera anticipada. Entonces, de pronto, empezaba a hablar, y gritaba, y daba golpes contra la pared y la música iba andando; la música iba por un lado y ella por otro. Pero tú te dabas cuenta de que todo aquello tan incoherente tenía una coherencia (Troyano 2007). ${ }^{152}$

Esta apreciación coincide con la percepción de mis informantes. Su vocalidad encarna el arrebato, el desenfreno, la violencia, la libertad de hacer y decir sin restricciones de ningún tipo. Hay una clara representación de valores y anti-valores en su canto, coligados a las maneras de su show y a lo que en los medios se sabía sobre su forma de ser. La vocalidad de la Lupe y su performance en escena son una clara muestra de ruptura con el establecimiento y aunque no haya sido una intención manifiesta sentar una posición política con su show, su audiencia podía percibirlo de esa manera. Pero ante todo, su audiencia percibía la «verdad» en su voz; cuestión que ampliaré en el siguiente epígrafe y que no necesariamente todos los oyentes denominan «verdad», pues algunos lo expresan como sinceridad en la interpretación o el «ser ella misma» en el transcurso de su canto.

\subsection{La verdad en la voz}

El atributo de «verdad» que se inscribe en determinadas vocalidades, dadas las complejidades de su uso como característica de una voz, es descrito constantemente a través de metáforas. Uno de mis informantes utiliza las palabras rock y rap para dar a

\footnotetext{
${ }^{151}$ Nótese el efecto de manera muy patente en temas como «Guajira», una guajira mambo de Arsenio Rodríguez interpretada con la orquesta de Tito Puente. Resalto en negrita los finales con voz hablada: Amiga pide otra copa caramba / que la Yiyiyi te invita / y aunque a ustedes no le importa voy a hacerles, pues, la historia, de mi vida. / Amé mucho ese querer / fue mi alma la más sentida. / Me traicionó el muy bandido / qué ingrato y mal proceder. / Él fue que me hizo querer, caramba, / el me hizo verme querida. / En mi casa me encerré / y llorando me quedé / se olvidaron mis amigos / solo mi madre lloraba / a Dios pedía y rogaba / que se salvara su hija. / Recuerden lo que les digo, caramba / que el dolor o en una cama / solo la madre nos ama, ay / no hay dinero, no hay amigos / linda guajira, mi son te llama. / Yo quiero bailar, quiero gozar /... Disponible en https://www.youtube.com/watch?v=zpgg n39ZOc.

${ }^{152}$ Texto extraído de la entrevista realizada al musicólogo Elio Orovio para el documental La Lupe Queen Of Latin Soul; producido y dirigido por Ela Troyano. Puede consultarse en: https://www.youtube.com/watch?v=26ONgK-GLig.
} 
entender la trascendencia de la vocalidad a esferas tanto culturales como políticas. Dicha trascendencia eleva la definición de rock o rap a un marco conceptual distinto, a una nueva categoría de significación en la cual los dos vocablos son connotados a partir de un cariz de fuerza, intensidad, transgresión o irreverencia. Tales características se articulan en la necesidad de confrontar la norma, de romper con un orden establecido históricamente que acusa una grave falta de sentido para las generaciones del pop americano y británico o las de la salsa latinoamericana. ${ }^{153}$ Por lo tanto, son categorías que trascienden a una definición cultural del fenómeno:

Prefiero el carácter en la voz de La Lupe. La sensibilidad de Maelo y de la Lupe es una sensibilidad más blusera, como arrastrada. Las notas no son tan precisas, pero como que sangran, casi. Y eso le da un carácter a lo que cantan, que los hace, para mí, preferibles. [...] Yo escucho «Teatro», o escucho a Maelo en cualquiera de sus formas: alucino... Y cuando incluso canta la salsa de Tito Puente, eso era una locura; esa mujer era una locura y «Eso es el rock para mí, su cara personal, de “verdad”, más allá de las normas y las formas correctas» (Hernández Buesa 2014, comunicación personal).

En la opinión de Hernando Gómez, que no se aparta de la anterior, la vocalidad de La Lupe contiene un elemento sexual que interpela fuertemente a la audiencia masculina. Para Hernando ello es muy notorio en «Watermelon man», tema de Herbie Hancock en versión jazz-funk de Mongo Santamaría. La intérprete abre el tema exponiendo sus llamados $^{154}$ y sus risas característicos sobre la base de la percusión. A lo largo del desarrollo de la pieza ejecuta tales recursos a ritmo con la base percutiva y añade pregones en inglés y en español (Puede consultarse la versión disponible en https://www.youtube.com/watch?v=CSOOOAaS8eY). La modulación de su voz con los elementos musicales es absoluta; se ajusta tan oportunamente al desarrollo de la pieza que, sin ser la voz melódica de la canción, pasa a tener un evidente protagonismo. Hernando observa lo siguiente sobre el referente sexual:

\footnotetext{
${ }^{153}$ El boom del pop en Estados Unidos se verificó paralelamente a la salsa en Nueva York. Mientras la juventud norteamericana encontraba identificaciones en los nuevos géneros, los latinos allí residentes porfiaban por el encuentro con sus raíces a través de los aires caribeños cuya fusión con las sonoridades del jazz y del pop no dio espera (Arteaga 1990; Ulloa 2009; Rondón [1978] 2007). No obstante, no puede decirse que su escucha haya quedado relegada a la salsa neoyorquina y otras músicas latinas. De hecho, la mayoría de mis informantes tienen un gran aprecio por el rock y algunos manifiestan sentir el mismo aprecio por ambos géneros.

${ }^{154}$ Tales llamados son unos prolongados ‘iAy!', interjección que se fusiona entre canto y recitado. Por lo general, cada intérprete de la salsa viejaguardera tiene unas marcas características en su interpretación, en términos de llamados, palabras o frases. Otros ejemplos muy conocido son el azúcar: ¡Azúca’! de Celia Cruz; iEcuajey! y iFuera zapato viejo! de Maelo.
} 
[...] es la sensualidad con la que ella lo hacía, con la que ella cantaba, el tono que ella le metía, ese picante que hacía de su vocalización algo excitante, especialmente para el público masculino. Entonces, eso le encantaba al espectador, al oyente y aún lo sigue haciendo. Es una voz única y exclusiva. [...] Ahí es donde se escucha ese coro y esa voz de La Lupe [Watermelon man], que es una voz chillona y excitante. Creo que eso fue lo que contribuyó para que tuviera tanto éxito (Gómez 2015, comunicación personal).

Esta descripción redunda en el ámbito de la sexualidad y aporta otra perspectiva sobre la interpelación de la vocalidad de La Lupe. El testimonio anterior, el de Alejandro, no descarta explícitamente el matiz sexual, lo que indica que en su alusión al «rock» que contiene esta voz, podría haber un indicador de esa índole. En efecto, Richard Middleton asevera que:

Las localizaciones y representaciones corporales de las voces populares las sitúan en un irreductiblemente universo de género. La vocalidad siempre está sexualizada, y esta cualidad nos llega a través de la pantalla de la diferencia de género, aunque sea una pantalla prestada menos que estable en los últimos años, a través de las críticas feministas y queer. ${ }^{155}$ (Middleton 2006, 91).

A partir de estas claridades esta parte del estudio se interesa en cómo la vocalidad es una fuente generadora de subjetividad y por lo tanto permite la performatividad del «yo»; la performatividad del sujeto de la escucha en la experiencia estética con la salsa. Si la propuesta es que la vocalidad conecta al personaje de una canción con el oyente, no suene en exceso obvio que conecte además la personalidad del intérprete.

En concordancia con las reflexiones sobre la vocalidad de La Lupe puede suponerse que para los salseros la voz no está desconectada de la personalidad del cantante. El salsero suele atribuir las características de la voz a las cualidades personales de quien canta. La vida de ciertos cantantes puede -o no- sintetizarse en ese «algo» que denota su voz. Roland Barthes ([1982] 1986, 252), propone al respecto:

En relación con el silencio, la voz es como la escritura (en el sentido gráfico) sobre el papel en blanco. El acto de escuchar la voz inaugura la relación con el otro: la voz, que nos permite reconocer a los demás (como la escritura en un sobre), nos indica su manera de ser, su alegría o su sufrimiento, su estado; sirve de vehículo a una imagen de su

155 «The bodily locations and representations of popular voices situate them in an irreducibly gendered universe. Vocality is always sexualized, and this quality comes to us through the screen of gender difference, albeit a screen rendered less than stable in recent years through feminist and queer critiques». 
cuerpo y, más allá del cuerpo, a toda una psicología (se habla de voces cálidas, de voces blancas, etcétera). ${ }^{156}$

Alrededor de estos rasgos el oyente empieza a identificar características personales en el cantante. Por ejemplo Pedro Patiño, otro de mis entrevistados, nos brinda su percepción sobre el reputado bolerista y cantante de música caribeña Daniel Santos (Puerto Rico, 1916 - Estados Unidos, 1992). Según mi informante, Santos fue un «personaje sórdido», descripción a la que vincula la voz ronca y oscura del cantante, la cual, en términos de Pedro, proyecta una «personalidad gris y un poco mezquina» (Patiño 2014, comunicación personal). Estas características conmueven profundamente a Pedro porque siente que en la vocalidad de este intérprete se encarna lo sórdido y, cuando lo escucha, siente que tiene la oportunidad de vivenciar aquella sordidez que en teoría tiene el cantante. Entonces, Pedro es sórdido porque en la experiencia estética de la escucha de Santos elabora el mundo gris y mezquino que le transmite la voz del cantante e integra el carácter del intérprete en sí mismo; en su propio cuerpo y persona.

Realmente Daniel Santos ha sido una voz emblemática para el bolero y en lo personal ha gozado de una reputación algo controversial. A propósito de la vida y personalidad del bolerista, Vicente Francisco Torres en su libro La novela bolero latinoamericana retrata la manera de pensar y de actuar de Santos. El primer marco de referencia que sirve de telón de fondo a la descripción del controvertido cantante son los complejos escenarios citadinos en los que se movía. Ciertos sectores y calles en los que deambuló el cantante estaban invadidos de burdeles, cabarets y cantinas, donde la vida era ruda y dispersa; lugares que al parecer le agradaban y lo hacían sentir en su casa; en los cuales, por cierto, se granjeó sus dos famosos sobrenombres: el «Jefe» y el «Anacobero» o el «Inquieto Anacobero».

El remoquete de Jefe se lo dieron los maleantes del barrio de Guayaquil, en Colombia, una vez que, desafiando los consejos de sus amigos, se echó a caminar por ese barrio lleno de prostitutas, pillos, criminales, tecatos y mariguanos. Entró a un sitio donde los maleantes escuchaban la música de la vellonera y, el cantinero, cuando lo reconoció, le

\footnotetext{
${ }^{156}$ Esta apreciación de Barthes completa muy bien la de Bourdieu sobre la construcción social del cuerpo. Aunque Bourdieu (1986) no explicitara la voz como un componente corporal, la integración de la voz a la corporeidad en términos de su teoría, es incontrovertible. Entonces, se vuelve más interesante el postulado allanado en la fenomenología sobre el cuerpo vivido y acopiado acertadamente por Pelinski (2005), ya que se topa con los dos autores franceses de la siguiente manera: así como el cuerpo anuncia la trayectoria social que lo ha concurrido, la voz y los incontables visos físicos, emocionales, psicológicos, y demás, que la atraviesan, anuncia dicha trayectoria también.
} 
preguntó qué hacía en ese lugar al que no entraban siquiera las fuerzas represivas. Cuando entre los malotes se regó el rumor de que allí estaba el Inquieto Anacobero, fueron a verlo y a decirle, entre patadas de marihuana, que no había ningún problema porque ahí él era el Jefe (Torres 1998, 103-4).

Esa personalidad fuerte y controversial de Santos es constituida y potenciada a la vez por las afirmaciones que de sí mismo expresó el propio intérprete. En el libro Vengo a decirle adiós a los muchachos, Josean Ramos recoge una declaración de Santos que reza:

Yo entro a cualquier barrio del mundo, porque en todos se habla un idioma común, el idioma de la pobreza, y aunque haya matones, tecatos, putas o contrabandistas, siempre me respetan. Para otro son barrios malos, para mí no. Yo sé lo que ha pasado esa gente porque yo nací así, qué carajo. Nací pobre y al pobre le echan la culpa de todo lo malo, pero eso no es así. Hay gente noble en esos lugares atestados de dolor. También hay malos criminales y toda esa pendejada, pero no son tantos. No se puede culpar a todo un barrio por dos o tres sinvergüenzas. Yo conozco todos esos barrios de Latinoamérica, he estado en todas sus barras, me he dado el trago con todos sus borrachos, y puedo decir que sectores como La Perla, del Viejo San Juan, hay en todas partes del mundo. La pobreza es la que hace barrios como El Fanguito, Barrio Obrero, Trastalleres, Dulces Labios, Shangai y tantos otros. En estos lugares hay poco dinero, y donde hay poco dinero hay delincuencia, hay necesidad, hay que robar. Ésa es la realidad de esos sectores marginados que tanto han contribuido al desarrollo de la música popular latinoamericana (Ramos 1993, 133). ${ }^{157}$

He citado ampliamente esta descripción por el detalle que contiene, lo cual reafirma la idea de que la voz y la vocalidad de Daniel Santos podrían resumir, de cierta manera, su forma de ser y lo que fue su vida. ${ }^{158}$ Así como entendimos con Pierre Bourdieu (1986) en la construcción social del cuerpo, cómo la imagen, es decir, la forma en que se presenta ante los demás denota la trayectoria de un cuerpo, la vocalidad demarca potencialmente, también, lo que ha sido su trayectoria. Por añadidura, hay que considerar que la vocalidad tiende a intervenirse con factores que afectan el ánimo; bien escribe Barthes que «la voz, que nos permite reconocer a los demás (como la escritura

\footnotetext{
${ }^{157}$ Guayaquil es el nombre de un barrio localizado en una famosa zona de tolerancia de la ciudad de Medellín, al que el intérprete realizó más de una visita.

${ }^{158}$ Emblemática canción que los públicos asocian directamente a su personalidad es «Despedida» (Vengo a decirle adiós a los muchachos), quizás una de las más versionadas de su repertorio. La novela de Umberto Valverde, mencionada atrás, lleva como título la frase más emblemática de la pieza.
} 
en un sobre), nos indica su manera de ser, su alegría o su sufrimiento, su estado». Por lo tanto, los oyentes suelen detectar algo en la vocalidad de sus intérpretes que anuncia una «diferencia» en determinada interpretación. A veces perciben, incluso, una desconexión entre el cantante y su canto.

Andrés Rodríguez, ${ }^{159}$ otro de mis informantes, siente que voces como la de Ángel Canales ${ }^{160}$ representan lo «malévolo» y cuando las escucha tiene la oportunidad de ser malo, puesto que siente que encarna la maldad. Y así sucesivamente otras voces como las de Celina Gonzáles, Benny Moré, Bobbie Cruz, por nombrar algunos, se reiteran en los entrevistados. Normalmente, cuando se intenta explicar el qué de la voz, los oyentes no encuentran las palabras exactas para expresarse fehacientemente. Se habla de potencia, intensidad, ritmo y se sobrentiende que hay algo más. Los oyentes encuentran términos genéricos, originados en el propio argot salsero, que se amoldan a lo que necesitan expresar. Entonces, las características que se atribuyen a una voz, a un timbre, a una manera de tocar, quedan perfectamente explicadas cuando se acude al término en cuestión. Sobre los anteriores cantantes concluyen que sus peculiares voces están impregnadas de «cierto sabor», entre otras características, sin embargo ese «cierto sabor» expresa lo que una correcta semántica no puede decir.

A nivel de la voz, los cantantes que interpretaban esta salsa brava, no eran voces educadas, eran unas voces, podríamos decir, como muy rústicas, y eso les daba como cierto sabor. Si analizamos, por ejemplo, la voz de Celia Cruz, ella tenía una voz muy varonil; ¡muy varonil! Ella era casi que tenor en la tesitura, pero el timbre era femenino. Entonces, era una voz rarísima; con mucha fuerza. Tuve oportunidad de verla en unos ensayos con el Grupo Clase cuando vinieron acá, y se da uno cuenta que a veces la orquesta, a pesar de que la orquesta Clase de Jorge Ramírez hizo un trabajo grandísimo con la música colombiana, son muy respetables y todo, pero había momentos en que uno sentía que no daban la talla para la cantante que tenían allí al frente. Era una señora que tenía una potencia de voz y una personalidad, y un manejo rítmico... Entonces,

\footnotetext{
${ }^{159}$ A Rodríguez lo conocí eventualmente en 2015 y mantuve una breve conversación sobre el tema. En ésta me planteaba el interés que le ocasionaban las voces salseras, sobre todo masculinas, que parecía que encarnaran en sus vocalidades, ciertos «trazos morales». De ahí su ejemplo con el cantante Ángel Canales.

160 Ángel Canales (1950) es un reconocido cantante de salsa; puertorriqueño radicado en Nueva York desde su infancia. Como muchos de su generación tuvo la influencia de la música jíbara (canción campesina portorriqueña) y de los clásicos salseros como Rafael Cortijo e Ismael Rivera. En Nueva York tocó -timbales- y cantó con las grandes leyendas del momento. Por cierto, forma parte de la nómina del álbum Beethoven's $V$ que se aborda más adelante en este documento. Se dice que en su canto se mezcla el dejo jíbaro con la sonoridad callejera de El Barrio. Hizo una versión del bolero «Dos gardenias», connotada por la peculiar voz con que la interpreta.
} 
pienso que la diferencia está ahí, en el manejo rítmico de la voz, en el manejo de la síncopa, en el manejo de fraseo, en los intervalos afinados que daban. De alguna manera yo lo asimilo como al Blues. Cuando estas personas tocaban con unos instrumentos que les faltaba una o dos cuerdas, y una guitarra rota, pero sonaba con un sabor y con un sentimiento que actualmente uno con una guitarra de última tecnología no es capaz de darle esas connotaciones. Entonces, como que ocurre igual ahí. Eran cantantes sin formación de técnica vocal pero daban en el punto exacto del sabor, de la fuerza y de la energía (Ramírez 2014, comunicación personal).

Ahora, en reflexiones más profundas sobre la vocalidad se extrapolan términos que cargan de significado la definición de ciertas voces y del efecto que causan en el entorno cultural. Retomo el testimonio de Alejandro que determina que La Lupe, Maelo ${ }^{161}$ y Héctor son los «raperos de la salsa», que la salsa es «rock y rap». Nos encontramos aquí ante un «préstamo de sentido» de otros dispositivos socioculturales e históricos de la música; podríamos aseverar que son metáforas más complejas. Esta definición de lo que comportan algunas voces se hace depositaria de un sentido que trasvasa los significantes. Pone en primer plano el rap y el rock entendidos como algo que supera la connotación de expresión musical. Ambos anuncian el rompimiento de los esquemas, la fractura del canon; precisamente, en su momento pasaron a ser formas en que los jóvenes le dijeron «no» a seguir el curso de una sociedad enferma, amoldada a las constricciones del poder y cuya construcción hegemónica impedía el desarrollo libre de los individuos. Son reacción y resistencia. Maelo y Héctor encarnan en su vocalidad tal disensión con el establecimiento:

Me gusta la salsa rockera. Tú pones, por ejemplo, «Aguanile», de Héctor Lavoe y Willie Colón, y es un tema muy especial, muy trabajado, muy elaborado, y pues ése era el rock de los grupos que estudiaron a los clásicos y luego se dedicaron a ser, pues, otra cosa. Me gusta la voz que tiene Maelo. Cuando yo miro las canciones de Maelo, no sé cuál poner porque no es un éxito; no hay un éxito, ¡Es escucharlo! Y el escuchar el cante de él, es lo que... es la gracia. Lo prefiero a él aunque entiendo que Héctor puede ser un mejor cantante. [...] La vocalidad de los dos es muy distinta. Maelo tiene un pregón muy original y Héctor tiene una voz privilegiada. Pero ambos mamaron la misma vaina, ambos mamaron la calle y son digamos “los raperos de la salsa” de alguna manera, ¿no?

\footnotetext{
${ }^{161}$ Hay diversos «Maelos» en la salsa, pero el entrevistado se refiere a Ismael Rivera, denominado por la crítica del campo «El sonero mayor».
} 
Cuando ves los pregones, lo que hacen es eso (Hernández Buesa 2014, comunicación personal).

A través del testimonio de los oyentes nos damos cuenta de que las voces están cargadas de múltiples matices que transfieren emocionalidad en la interpretación; transmiten estados emocionales que los oyentes vivencian o reviven cuando las escuchan. Hernando Gómez afirma que las personas escuchan la música de acuerdo con el estado de ánimo que tienen; por ejemplo, temas melancólicos del corte «Consejo de oro» o «Periódico de ayer» ${ }^{162}$ en la voz de Héctor Lavoe, conllevan una buena carga de nostalgia y melancolía, al igual que de reflexión, pues enseñan el día a día de la vida. Al preguntarle sobre las versiones diferentes, es decir en la voz de otros intérpretes, Hernando dice:

[...] lo hicieron en otras versiones con otros arreglos, otros intérpretes, pero igual que la versión original: no la hay. O sea, yo creo que nadie con otros arreglos, incluso metiendo otra sonoridad mucho más rica y otra improvisación,... uno siempre se queda con la versión original. [¿ंPor qué?, qué es lo que tiene esta voz de Héctor que no se encuentra en otro intérprete:] La originalidad, lo auténtico. Héctor era un cantante que lo hacía con esa fascinación, con esa pasión; con esa humildad, con esa sencillez que se entregaba y se inspiraba y le daba todo a un público. Ése fue el encanto que tuvo Héctor Lavoe para enamorar a tanto público y hoy por hoy después de más de 20 años de muerto aún se sigue recordando (Gómez 2015, comunicación personal).

Apoyando en cierta medida la opinión de Hernando sobre «la autenticidad de la versión original» -original en el sentido de inicial, inaugural-, Pedro (Patiño 2014, comunicación personal) indica que la canción «El cantante» no es nada en la voz de Mark Anthony», quien la ha interpretado también, y aunque el propio compositor Rubén Blades la canta, nunca le dará la talla a la versión de Héctor Lavoe. Durante el transcurso de la entrevista, Pedro iba mostrando en su ordenador diversos videos o audios donde la comparación de los timbres entre Lavoe y Antony revelaba contrastes considerables. De las muchas diferencias halladas en los dos intérpretes, (por supuesto, entre ellas una muy notoria y es que el pregón de Lavoe no lo evidencia Antony) Pedro enfatiza el detalle de la emisión de la voz. Le impresiona y complace la limpieza de

${ }^{162}$ Los temas «Consejo de Oro» y «Periódico de Ayer» pertenecen a la producción De ti depende de 1976, de Willie Colón. El primero es un tango de Arquímedes Arcidiácono y los arreglos para salsa son de Louie Ramírez. El segundo es un tema de Tite Curet y se ha convertido en uno de los clásicos del repertorio personal de Lavoe y del repertorio salsero en general. 
emisión del sonido de Lavoe en contraposición al ruido de la voz de Antony. Ese ruido es una especie de aire que acompaña la emisión del sonido y a veces es parte del estilo. Sin embargo, este detalle se vuelve inestimable, puesto que Pedro considera que no tiene sentido establecer semejante comparación.

Hernando agrega a la descripción de la voz un atributo específico: la originalidad, lo auténtico, que corresponde a la forma de ser de Lavoe caracterizada, entre otros aspectos, por la humildad y la sencillez. Esto es anuncio de una percepción directa del público sobre un índice de «verdad» en una voz. Aunque no pueda arriesgarse una definición precisa ni mucho menos completa que pueda abarcar todos los significantes que resulten en la «verdad», sí hay una aproximación al concepto. Para Hernando «Periódico de ayer» en otra versión no conduce a la misma percepción, por lo cual se explica que de aquí parta, ahora, una asociación inevitable de la vocalidad y la voz con la figura del intérprete. Así entenderíamos que las vocalidades de Santos, La Lupe o Lavoe son su misma representación; la voz como representación de la persona, del cantante, del intérprete, que en términos de Barthes apunta a toda una psicología. ${ }^{163}$

\subsection{Intérprete y figura: la apropiación de las historias de vida}

La figura del intérprete es lo que el género musical construyó de él y la forma en que lo construyó su público: la imagen. En la salsa se produce una interpelación inequívoca de la figura del cantante en su público, cuyo atuendo no es el ajuar que representa al héroe o a la víctima teatralizados y enaltecidos en la escena de la ópera, por ejemplo, sino al ídolo de imagen más cercana y actualizada, que invierte su posición y se identifica con la gente y sus pasiones. Podríamos estimar que en la ópera la gente se identifica con el personaje; en la salsa la gente se identifica, además, con el intérprete. El cantante cumple a la vez el papel de vocero de unas multitudes que necesitan compartir el infortunio, denunciar el atropello, solidarizarse en el exilio, comunicar el éxito y expresar el goce que producen los cuerpos. No solo identifica al oyente; lo representa. Se sabe bien que la mayoría de cantantes de salsa tienen una extracción humilde, provienen de la calle; ésta y quienes la habitan forman parte de su recorrido. A la hora del espectáculo es el cantante con su historia y sus pasiones quien sale al escenario.

\footnotetext{
${ }^{163}$ El texto «El hombre que respira debajo del agua: Trans-Boricua memories, identities and nationalisms performed through the death of Héctor Lavoe» (Valentín Escobar 2002) marca algunos de los trazos que hacen de la vocalidad de Lavoe una de las más singulares en la historia de la salsa.
} 
Por citar un caso, ilustro con Frankie Dante una de las formas en que su figura quedó registrada para la historia salsera. Dante fue un cantautor neoyorquino que en su momento gozaba de gran acogida entre el público juvenil, pese a que no estuviera en el foco del movimiento comercial de las grandes disqueras:

Frankie Dante, extravagante de la salsa, incomprendido y querido, vilipendiado y adorado. Su timbre borrachón (versión ebria de Ismael Quintana), sus arrebatos juveniles y la humilde disquera en que grabó lo condenaron a las catacumbas del comercio musical, elevándolo, sin embargo, a la categoría de 'underground' y esto se traduce: músico de una élite ¿De quién? De los elegidos de entre el sótano: La plebe de la 'cloaca'. Con su combo de insurrectos desterrados al subterráneo inauguró su rumbón con diferentes direcciones, sentando así desde un principio, lo diferente y refractario de su credo. Era 1968 y Dante puso el pecho, como el jíbaro indomable que era, ante la crítica del 'stablishment’ salsero de la época para ¡Ay felicidad! de la masa subversiva que lo acompañaba. (Yllahuamán Chipana 2004).

En una aproximación al análisis intertextual del álbum Beethoven $V,{ }^{164}$ publicado en la Revista colombiana A contratiempo, explico cómo Dante controvierte con su performance la escena salsera neoyorquina. Su atuendo, su actitud, su gesto, sus letras con una impronta de denuncia social explícita, son insurrección dentro de la revolución que ya era en sí misma la salsa.

El inmigrante latino visto como ciudadano de segunda categoría fue la causa para que muchos artistas se revelaran y manifestaran su inconformidad. Frankie Dante compuso letras de corte protesta en las cuales vierte su posición personal; letras con una gran carga de crítica y denuncia. Por ejemplo las canciones "Si yo fuera presidente”, “Me quieren crucificar”, "Venceremos”. Pero no sólo compuso letras de corte protesta quizás en un intento de reivindicar el estatus igualitario de los latinos en EEUU, sino que también adoptó una actitud procaz en su manera de presentarse ante el gremio salsístico y ante el mismo público que lo seguía y que era conocedor de sus estrambóticas presentaciones. Sobre su manera de presentarse en la escena cultural del momento, César Rondón (2007:224) resuelve: «Dante, que es una de las tantas víctimas de las famosas “listas negras” del ambiente latino de Nueva York, siempre se caracterizó por un espíritu rebelde

\footnotetext{
${ }^{164}$ Beethoven's V es un álbum de Markolino Dimond \& Frankie Dante, producido por Larry Harlow bajo el sello Cotique en 1975.
} 
e irreverente que no dejó de ser consecuente con algo que la salsa arrastraba en el fondo: el desesperado sentimiento del ser marginado que exige ser oído. Sin embargo, Frankie nunca llegó muy lejos, no podía hacerlo. Y no tanto por su rebeldía y las “listas negras” [...]». (Delgado-Ordóñez 2014, s.p.).

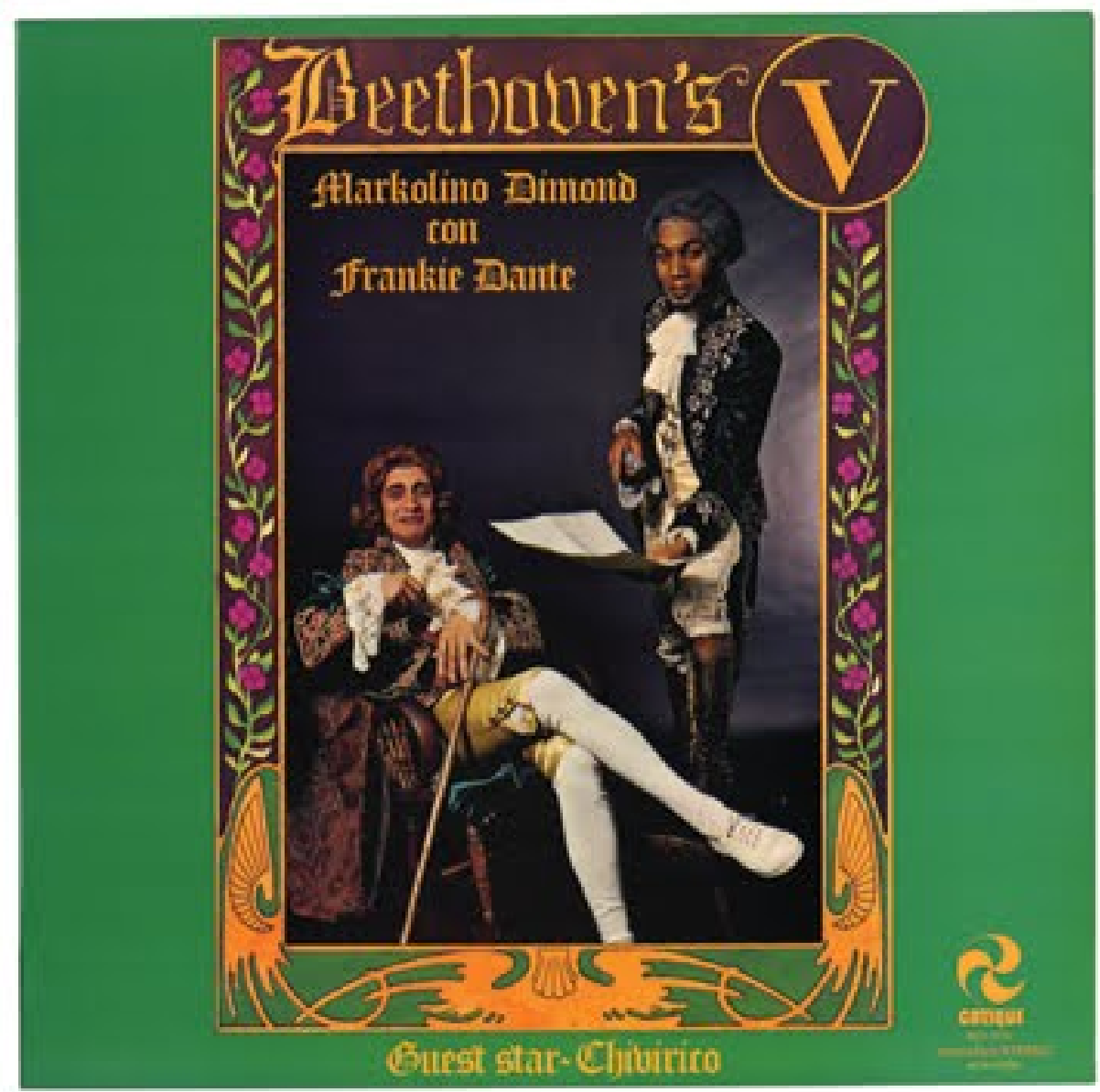

Figura 14. Carátula Beethoven's $V$ anverso. ${ }^{165}$

De esta forma, la imagen de Dante fue construida -y auto-construida- en el seno de una comunidad emergente, cuya juventud de herencia migrante buscaba íconos que representaran su manera de ser y de estar en un mundo que no le era suficientemente afable. Con Dante el público estructuraba la irreverencia, la rebeldía y, de hecho, una posición política como componente de la sociedad estadounidense. Un aspecto peculiar de su postura anti-establecimiento se ve claramente en los nombres de sus canciones y en las carátulas de sus discos. Símbolos tales como atuendos, colores, posturas, gestos,

\footnotetext{
${ }^{165}$ Figura extraída de la WEB oficial de Fania; fuente http://www.fania.com/products/beethovens-v.
} 
nombres o anacronismos forman parte de la expresión de su consagrada rebeldía. Nótese en las siguientes imágenes, figuras 8 y 9, los elementos anacrónicos e incoherentes del vestuario y de los roles de los personajes; anverso y reverso de la carátula del álbum Beethoven’s $V^{166}$ :

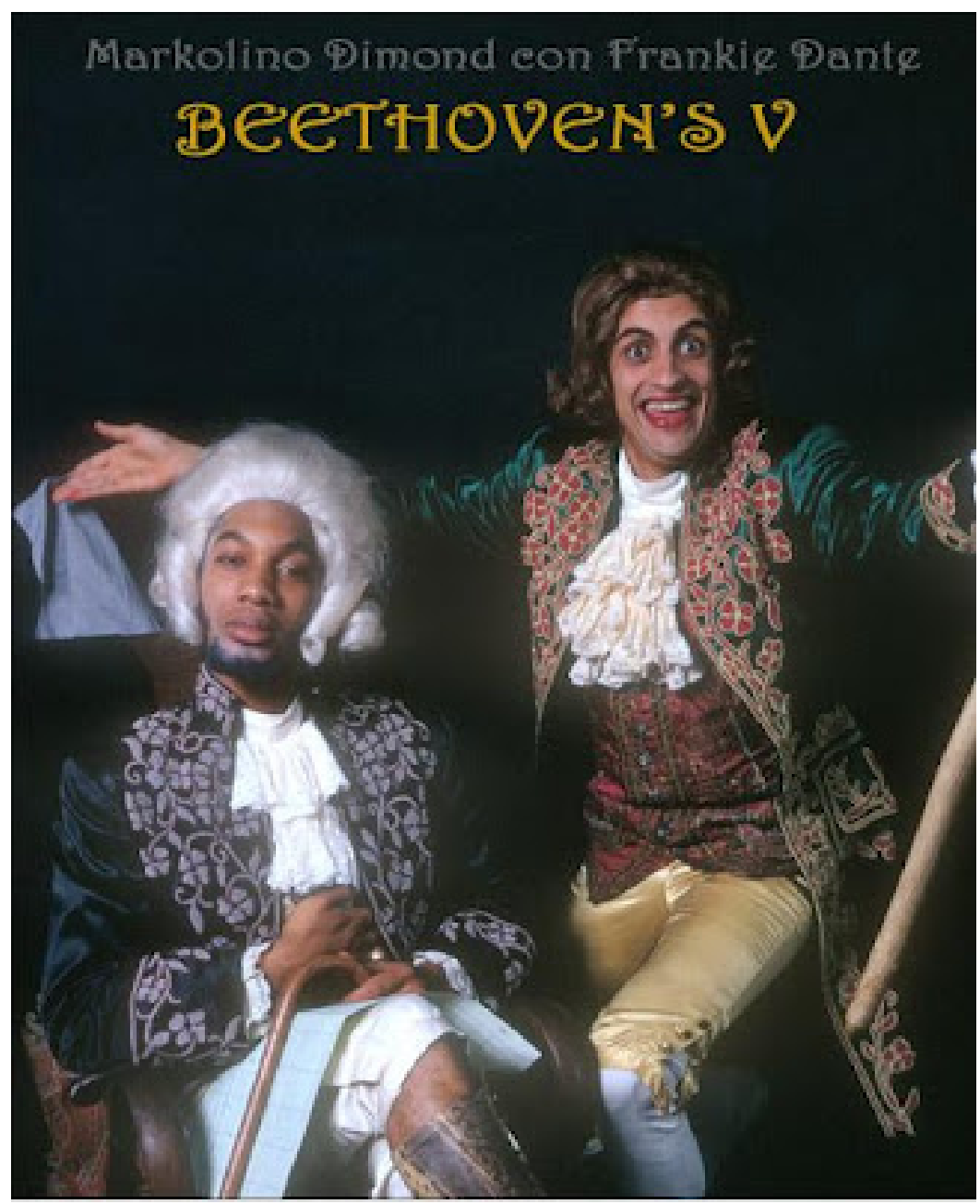

Figura 15. Carátula Beethoven's V reverso. ${ }^{167}$

Entre las conclusiones que arriesgué en el artículo mencionado sobre las posibles interpretaciones de la intertextualidad del álbum, reparé en la importancia que tiene la transgresión simbólica de la norma. Si a un público, a una audiencia, no le es factible

\footnotetext{
${ }^{166}$ En el artículo mencionado hago referencia a un grupo de elementos intertextuales del álbum, de tipo sonoro y gráfico, y me acerco a una interpretación crítica contextualizada en lo histórico de la producción. ${ }^{167}$ Figura extraída de la WEB oficial de Fania; fuente http://www.fania.com/products/beethovens-v . No todas las ediciones del disco incluyen la figura del reverso; algunas no utilizan ninguna y otras contienen más imágenes en tamaños menores, como sub-cuadros donde se presentan incluso más poses.
} 
materializar dicha transgresión, al artista sí; pues tiene una plataforma que se lo permite. Por consiguiente, el artista interviene en la realidad desde lo simbólico. El reverso de esta carátula expone un cambio de roles entre el mecenas y el sirviente que va más allá del mero intercambio; porque no solo es el sirviente quien se convierte en «el señor», sino que el señor es negro. En los antecedentes de esta tesis se recordaba a minorías latinas y negras victimizadas en la exclusión, no solo en Estados Unidos, sino en Colombia también. Al respecto anoto:

Podríamos contar con múltiples conjeturas, una opción interesante es que tales imágenes se asuman como una burla a la modernidad. Aquel transcurrir intertextual que además de recorrer el espacio físico transgrede múltiples dimensiones temporales, nos invita a pensar en los diversos artilugios que la modernidad ha diseñado para ejercer resistencias a los cambios socioculturales que deberían haber operado en consecuencia con el devenir histórico de las sociedades. Markolino Dimond y Frankie Dante caricaturizan ese paso que el mundo moderno se niega a dar decididamente, y que solo es posible a través de las batallas que se dan para imponer y ostentar el sentido (Delgado-Ordóñez 2014, s.p.).

Cito un segundo caso relacionado con Héctor Lavoe. Quizás uno de los intérpretes más emblemáticos de la última generación de la salsa brava de la Fania. ${ }^{168}$ La gente y el gremio especializado reconocen los privilegios de su voz. Se habla a menudo de su excelente y extendido fraseo, de la impecable dicción, de la naturalidad del pregón y del canto, pero se reconoce también que detrás de esta retahíla de atributos un sino marcó desde niño su vida: las muertes de sus seres queridos más cercanos que hicieron de él una verdadera catástrofe personal. ${ }^{169}$ Para empezar, la muerte de su madre cuando

\footnotetext{
${ }^{168}$ Sobre la vida del cantante pueden verse el libro biográfico de José Pérez y Antonio Mejias (1997) y el libro de Marc Shapiro (2007). En lo personal, pienso que las distintas páginas que ha escrito Izzy Zanabria sobre la salsa, profundizan realmente en la emocionalidad de los cantantes. No obstante, sobre la relación del intérprete y su público aún no se ha escrito algo determinante.

${ }^{169} \mathrm{~A}$ la muerte de Héctor Lavoe en 1993, Willie Colón escribiría los siguientes comentarios: «Graduado en la Universidad del Refraneo con altos honores. Miembro del Gran Circulo de los Soneros, poeta de la calle, maleante honorario, héroe y mártir de las guerras cuchifriteras donde batalló valientemente por muchísimos años. Los 'capitanes de la Mandinga' lo respetaban. Por eso lo bautizaron 'El Cantante de Los Cantantes'. Los 'beginers' le temían. Cuando se trataba de labia, Héctor Lavoe era bravo. En cuestiones de negocio, amor y amistad, no lo era. El pueblo fue cómplice de esta tragedia. Héctor le podía mentar la madre a todo el mundo y el público se reía. Lo malcriaron. La historia de Héctor Lavoe está llena de traiciones y desengaños. El jibarito good looking que volvía a todas las mamis locas quería también ser un malote de barrio. Con el tiempo, los 'regalitos' de sus 'amigos' del traqueteo se convirtieron en gruesas y pesadas cadenas. Este fallo repercutió en una serie fatal que al final nos llevó a ese muchacho que le cantó al Todopoderoso con todo su corazón. También fue traicionado por el mundo del negocio; disqueros que siguen viviendo como jeques sauditos vendiendo sus discos y revendiéndolos en CD sin pagar regalías, mientras Lavoe quedó lánguido en su pobreza; promotores que
} 
apenas contaba con tres años. En adelante, una pérdida tras otra, incluidas las de su hermano, su madrastra y su propio hijo, fueron consumando el prontuario trágico del cantante. Se sabe bien que a esto se suma la separación profesional de Willie Colón, el incendio de su apartamento en Nueva York, la calamitosa vida de drogadicción, el suicidio frustrado y la inextinguible enfermedad del SIDA. El tema «El día de mi suerte» compuesto por Willie Colón, y uno de los grandes éxitos del cantante, expresa de manera muy sensible los anhelos de la gente de barrio para quien la desventura es un círculo vicioso que solo puede soslayarse en la buena suerte. Puede escucharse la grabación disponible en https://www.youtube.com/watch?v=qZK2wCpvwZg. Al mismo tiempo se encuentran asociaciones con deidades, a quienes se recurre con esperanza en un intento de mitigar los pesares de una vida mísera. Igual que siempre, el tema de la religiosidad fue otro de los sellos distintivos de Lavoe y, en cierto sentido, el tema descubre sus propias aflicciones que no son ajenas a las de la gente normal de las clases medias y bajas. ${ }^{170}$

\section{El día de mi suerte ${ }^{171}$}

Coro: Pronto llegará el día de mi suerte, sé que antes de mi muerte seguro que mi suerte cambiará.

Cuando niño mi mamá se murió, solito con el viejo me dejó.

Me dijo: sólo nunca quedarás porque él no esperaba una enfermedad.

A los diez años papá se murió, se fue con mamá para el más allá,

y la gente decían al verme llorar: no llores nene que tu suerte cambiará, y ¿̇cuándo será? ${ }^{172}$

le ofrecían migajas para poder vender boletos a sus espectáculos donde exhibían a "El cantante de los Cantantes" en su agonía; impostores tratando de reclamar la carrera y la memoria de Héctor Lavoe como propiedad personal; la comunidad latina legal también le dio la espalda cuando reclamamos de su ayuda para defenderlo contra la explotación; y yo, que también lo traicioné al no tener el valor de verlo en esa condición» (Rondón [1978] 2007, 433-34).

${ }^{170}$ En el siguiente subcapítulo titulado «La subjetividad en la lírica del lenguaje callejero», hago alusión al poema «Los nadies» de Eduardo Galeano, con el fin de mostrar las maneras en que las líricas literarias y musicales han hecho caso de la situación precaria de las clases menos favorecidas, de lo indignante de la vida en las formas en que los estados modernos han objetivado e «individualizado» -en la expresión foucaultiana, a los sujetos del siglo XX y posteriores.

${ }^{171}$ Tema perteneciente al álbum Lo mato de 1973; el último álbum de Willie Colón en sociedad con Héctor Lavoe.

${ }^{172}$ Anoto el resto de la canción: Ahora me encuentro aquí en mi soledad pensando qué de mi vida será, no tengo sitio dónde regresar y tampoco a nadie quiero ocupar. Si el destino me vuelve a traicionar te juro que no puedo fracasar, estoy cansado de tanto esperar y estoy seguro que mi suerte cambiará, y ¿cuándo será? / Sufrí la parte de mi vida ya sin un complejo de inferioridad, por eso no me canso de esperar pues un día Dios a mí me ayudará. Y el día que eso suceda escuche usted a todo el mundo yo le ayudaré porque tarde o temprano usted verá cómo el día de mi suerte llegará, y ya lo verá. / Muchas veces me pongo a contemplar que yo nunca a nadie le he hecho mal, ¿por qué la vida así me ha de tratar si lo que busco es la felicidad? Trato de complacer la humanidad pero mi dicha aquí ha sido fatal no pierdo la esperanza de luchar y seguro que mi suerte cambiará, pero ¿cuándo será? / Esperando la vida he de pasar, este martirio no podré aguantar, y pregunto hasta cuándo durará, tal vez, si lo podré 
Coro: ...

Esperando mi suerte quedé yo pero mi vida otro rumbo cogió,

sobreviviendo en una realidad de la cual yo no podía ni escapar.

Para comer hay que buscarse el real, aunque sea contra esta sociedad,

a la cárcel te escribe mi amistad, no te apures que tu suerte cambiará, oye verás.

Rondón relata otro de los sinsabores de Lavoe luego de que la crítica declarara fallido el concierto de 1988:

Ese día, luego de lo que la crítica calificó como “un concierto fallido” en el coliseo Rubén Rodríguez Bayamón, Héctor Lavoe regresó a San Juan. Subió a su habitación en el octavo piso del Hotel Regency y se lanzó al vacío. Las conjeturas por el intento suicida no se hicieron esperar: exceso de droga o exceso de tristeza, quizá. La muerte accidental de su hijo adolescente fue un trauma terrible que jamás pudo superar. En todo caso, el propio Lavoe observó con cierto desdén la circunstancia. Optó por la indiferencia y el silencio antes que entrar a explicar los absurdos detalles de su tentativa mortal. De cualquier manera, en los cinco años que siguieron a aquella espantosa tarde en que lo levantaron destrozado y sangrante del pavimento, ya nada fue igual para Héctor, y cualquier referencia a ese lustro, en el que el cantante dejó de serlo, es preferible borrarla rápidamente. Su muerte definitiva -que no necesariamente la verdadera- ocurrió en Nueva York, también en junio, en 1993 (Rondón [1978] 2007, 432).

La virtud y la tragedia que se cimentan en la figura de Héctor Lavoe permiten apreciar que en ciertas ocasiones las identificaciones no se generan directamente por el placer que causa la semejanza, la volición de ser el otro más que el hecho de imitarlo, como expresara Butler ([1993] 2002, 35), o cuando Hall mantiene que la identificación se ratifica en el reconocimiento de un algo en común con otros o con un ideal (1996a, 15). Luz Estela, informante referenciada en el capítulo anterior, declara que le apasionan tanto las letras de la salsa como las historias de sus intérpretes. Al igual que muchos melómanos interpone la categorización primordial del género fundándolo en la alegría y asevera que la variedad temática, en sus propias palabras, «la mata», sobre todo al reflejar «tantas cosas» de la vida diaria. Las historias le impresionan de manera contumaz, pero su identificación se dispone en las líricas antedichas y en la conmoción

sobrellevar. Si el destino me vuelve a traicionar te juro que no puedo fracasar, estoy cansado de tanto esperar y estoy seguro que mi suerte cambiara, pero ¿cuándo será? 
corporal que le genera el sonido. Pero asimismo se ha generado un sólido lazo emocional entre ella y el intérprete a raíz de las tragedias biográficas que tanto la conmueven. A partir de ellas Luz Estela ha hecho una interpretación muy íntima y particular de la desgracia personal de sus cantantes que explica de la siguiente forma:

Son muy tristes las historias de los intérpretes: Joe [Arroyo], Héctor,... Cómo una música tan alegre, tan feliz, lleva a la descomposición, a la autodestrucción. Drogas, tragedias, todo ese mundo los destruyó; ¡la música los llevó a eso! (Barreiro 2014, comunicación personal). ${ }^{173}$

De cualquier manera se generan unos afectos de los públicos para con sus cantantes; afectos que redundan en complejos sistemas de protección, compasión y defensa. No es foco de este estudio el análisis psicológico de estas sujeciones, pero son palpables los sentimientos de posesión del artista y su desgracia que inundan realmente a un melómano. Quizás no se sugiera una identificación directa mientras la adversidad no sea parecida a la de su oyente, lo que no significa que el aparato de identificación se trunque sino, más bien, que tiene implicaciones más complejas. Un síntoma bastante perceptible de esta identificación-posesión del artista y su historia trágica es la impotencia manifiesta en el relato de los informantes; la tristeza y la frustración se incorporan en ellos cuando ahondan en los pesares de ese «otro» al que no pueden salvar. ${ }^{174}$

Se determina con estos aspectos que la apropiación de las historias de vida de los intérpretes es bastante particular en tanto muestra dos estados latentes de percepción de la historia. Por un lado, el artista como personaje que ha muerto y por otro, el artista que siempre está vivo mientras su música continúe escuchándose. Cuando mis entrevistados hablaban sobre la vida de un artista, o sobre cómo cantaba, lo hacían en pasado, pero cuando compartían conmigo su música para mostrar pormenores o lanzar juicios sobre determinada interpretación lo hacían siempre en presente.

\footnotetext{
${ }^{173}$ Desafortunadamente la conversación con Luz Estela Barreiro fue ocasional y breve. Luego no fue posible contactarla otra vez. No obstante, se repite cierta idea de solidaridad o compasión por el cantante en muchos melómanos. Recuerdo que hace bastantes años, siendo niña asistía a los cursos de música para niños en la Universidad y escuché casualmente una conversación de pasillo, en la que dos músicos salseros adultos hablaban sobre Héctor Lavoe. Querían explorar la posibilidad de llevarlo a Colombia, nuevamente- y tenerlo en su propia casa para que se recuperara y volviera a la carrera, debido a que su familia y todos sus amigos le abandonaron sin más. Estoy hablando de 1990 más o menos. Lavoe falleció en 1993 en Nueva York.

${ }^{174}$ Véase la remisión a la entrevista de mi informante Francisco Cantor sobre el bolerista cubano Panchito Riset en el capítulo I subcapítulo III.
} 
Me impacta escuchar a Héctor porque ese hombre le ponía corazón a la canción, y no sé, me da la impresión de que sentía lo que estaba cantando. Entonces, eso para mí es muy importante porque no es solamente detrás de un micrófono cantar por cantar. Con una excelente orquesta, con una excelente sonoridad sino esa pasión que le colocaba a la canción. Y que uno, pasan los años, lo escucho en un acetato en un CD, llámese cómo se llame, lo veo en un video y uno todavía “siente” la pasión del tipo, de él cantando. ¡Como cuando tú escuchas a la Piaff! (Forero 2015).

Podemos comprender que el cantante es la personificación del habitante del barrio latino; es la encarnación del ser humano, demasiado humano, pero como cantante es finalmente ídolo. Es mitificado por el público en muchos aspectos, desde sus hazañas artísticas hasta sus vivencias personales desgarradoras y profundamente humanas. Finalmente muere. Si no muere, no sería mito. Muchos salseros se identifican con el cantante y el mito al considerar que la salsa ha muerto y la generación salsera está muriendo. ${ }^{175}$ Mis entrevistados, sobre todo los de más edad, no se oponen a esta muerte; al contrario ven en ello la glorificación de la música. Definitivamente, sí hay una constitución de mito en torno al intérprete, con lo cual es posible asociar esto a una narrativa épica: el artista como héroe o incluso antihéroe. La alusión a ciertos artistas que en su vocalidad y la construcción de su figura/imagen encarnan al ser humano y al ídolo es una constante en los salseros: Héctor Lavoe, Ismael Rivera, La Lupe, Cheo Feliciano, por nombrar algunos, están siempre presentes en los relatos de los salseros. Ahora, hay que dar lugar y peso a la manera en que los medios y el colectivo receptor va construyendo la imagen del cantante. Cuando el público construye la imagen de su cantante, no es posible descartar la carga simbólica que adquiere el artista, la cual media en el proceso performativo tal cual se anunciaba en el primer capítulo. Con todo, es imprescindible poner sobre la mesa que en la apropiación de las historias de vida de los intérpretes, también juega un papel sustancial la competencia musical supeditada al conocimiento del oyente. En ese sentido, la percepción musical difiere entre oyentes con más competencias que otros, puesto que la información alrededor de un intérprete o

\footnotetext{
${ }^{175}$ En esta materia es muy interesante el estudio de las honras fúnebres de los salseros. Arquetipos del fenómeno se pueden apreciar en las muertes de Héctor Lavoe en Manhattan-Nueva York, Estados Unidos, 1993; Ismael Rivera en Santurce, Puerto Rico, 1987; Tite Curet en Baltimore, Estados Unidos, trasladado enseguida a San Juan, Puerto Rico, 2003; y la monumental ceremonia a Celia Cruz en La Quinta Avenida de Nueva York, que fue cerrada por orden del alcalde y concluida en la connotada Basílica de San Patricio, después de pasar por New Jersey, lugar donde falleció y Miami donde la copiosa comunidad cubana y latina le rindiera sus respetos en 2003.
} 
tema musical interfiere en cierta medida en la experiencia de escucha de determinado cantante.

\subsection{Subjetividad y lírica del lenguaje callejero}

Frith observa que una de las funciones sociales de la música es la de «administrar la relación entre nuestra vida emocional pública y la privada» ([1987] 2008, 423). Ante la banalidad con que suenan algunas declaraciones sentimentales en lenguaje cotidiano, como las de amor, el oyente se afianza en la eficacia de la canción. Con una forma más intensa y sublimada, el lenguaje de tales afectos resulta suficientemente fértil cuando se sustituye la verbalización propia de las personas por la lírica elaborada «poéticamente» de las canciones. Las canciones se constituyen en «formas públicas de expresiones privadas» (Frith [1987] 2008, 424), con lo cual la identificación del oyente con el intérprete, el personaje o la emoción relatados, se convierte en una identificación con las letras que canta. En la salsa viejaguardera, por cierto, en muchas ocasiones los temas eran escritos para ser cantados específicamente por determinados intérpretes, o se reservaban en exclusiva a alguno de ellos cuando una versión había consolidado un canon interpretativo.

Pero lejos de las connotadas declaraciones sentimentales, presentes por supuesto en el género salsero, esta sección efectúa un análisis del lenguaje callejero inserto en la poética de las canciones, para lo cual se han determinado dos temáticas tratadas extensa y profundamente en la salsa, puesto que articulan una realidad del habitante del barrio que difícilmente se trata de forma tan abierta en otros géneros: el encierro en prisión y la delincuencia. Con «Las tumbas» y «El preso» se hace un acercamiento al estado de inquietud y desazón del encarcelado. En las dos obras es el mismo sujeto quien canta las conmociones de su encierro. Con «Pedro Navaja» y «Juanito Alimaña» se esboza el estado de alerta, prevención y miedo del transeúnte en la barbarie de la ciudad postmoderna latinoamericana. En las dos canciones es el «otro», el vecino, quien cuenta los pormenores del delito en las calles del barrio popular, que incrementan las dificultades de la vida en semejantes condiciones del tejido social. Para Claudia Forero el malestar social de la ciudad colombiana es un vivo reflejo de lo que acontecía en El barrio. Citando, asimismo, el documental Nuestra Cosa Latina, que presenta una detallada fotografía de la vivencia callejera, asevera: 
Yo escuchaba en ellos [los intérpretes] que lo que decían y sentían era lo mismo que yo estaba viviendo o era lo mismo que yo veía que vivía mi vecino; o alguien de mi entorno. Y que pese a que estaban a kilómetros de distancia, era el mismo sentir. [...] Esa canción social me empezó a impactar, veía yo que el problema es humano. No solamente Latinoamérica (Forero 2015, comunicación personal).

La descomposición social se ha visto también reflejada en la salsa, la cual le canta al delincuente que oficia en las calles y al convicto que purga una condena. La cárcel ha sido un tema muy sentido y recurrente tratado desde el son hasta el bolero, según José Arteaga, quien al mismo tiempo describe la estrecha relación entre el encierro y el canto caribe: ${ }^{176}$

Una de las razones para que existan tantos cantos a la cárcel en la música del Caribe y en la salsa es que muchos de sus intérpretes han pasado por la experiencia penitenciaria y es el caso de Daniel Santos, Ismael Rivera, Marvin Santiago, Cheo Feliciano y Ramón Rodríguez, entre otros, además de la enorme cantidad de salseros que tienen problemas judiciales (Arteaga 1993, 117).

A propósito de esta materia, diversas agrupaciones se presentaron en los reclusorios de América Latina y el Caribe; a Colombia llegaron también algunas. En la obra Celia Cruz: Reina Rumba ${ }^{177}$ el escritor Umberto Valverde relata cómo se vivió la visita de La Sonora Matancera en la cárcel de la ciudad de Cali. A manera de aparte autobiográfico, muestra a la vez su participación en la escena, que dibuja como un cuadro de pobreza y locura conmocionante y siniestro, amenzador. La turba que esperaba impaciente a la Sonora Mantancera y a Celia Cruz tuvo que ser abierta por la fuerza abatidora de los bolillos de los guardias:

Me sorprendía un hombre de unos 45 años, subido en un muro, con presencia de duro y quizás el único en apariencia aceptable. Tener derecho al muro era un privilegio. Miraba a los cantantes. Apretaba sus manos. A veces, con los otros, hacía el coro. Y se callaba, el rostro tenso, haciendo un esfuerzo para no quebrarse, para no desatarse en esa furia

\footnotetext{
${ }^{176}$ Del mismo autor se puede ver el estudio sobre las letras de la salsa que incluye el canto salsero a la violencia y a la descomposición social. En «La nueva salsa (o el otro Caribe)» (1989), «Las ciudades de la noche roja» (1993), «Las letras de la salsa» (1988).

${ }^{177}$ La obra de Umberto Valverde Celia Cruz: Reina Rumba, narra biográfica y literariamente la vida de la guarachera cubana desde se país natal hasta su residencia definitiva en Estados Unidos, sin obviar su estancia en México. En la obra se caracteriza en profundidad la personalidad de Cruz y se enfatiza lo que significó su presencia por las innumerables ciudades y escenarios en los que transitó. La ciudad de Cali, lugar de origen del autor, ocupa un especial lugar en el libro de Valverde.
} 
incontenible de saberse jodido, reviviendo esas canciones cuando estaba libre y las oía en una cantina, al lado de una mujer. [...]. Se sabía que venía Celia y los quinientos presos, que parecían mil, volvieron a pararse. Gritaban su nombre y en un movimiento ondulatorio se acercaban a la tarima. Me fui hacia atrás. La Sonora, con las trompetas de Calizto Leicea y Alfredo Chocolate Armenteros, y el piano de Javier Vázquez, empezaron la melodía de Burundanga. Y se formó la grande. Celia Cruz entró, con unos slacks, blusa negra con vivos brillantes y un peinado hacia lo alto. El garrote volvió a funcionar. Celia trataba de apaciguarlos. Sin poder evitarlo se me vinieron las lágrimas. También vi que Larry Landa se secaba el rostro. No sé cuántas veces lloré. Aunque los emocionaba y los hacía vibrar, Celia Cruz los hipnotizaba con su voz y entraron en un letargo que se aumentaba con la manera de hablarles, como si fuera la madre ausente (Valverde 1981, 104-5).

Retornando al asunto del canto al preso, cito un fragmento del texto de «Las Tumbas», ${ }^{178}$ composición de Bobby Capó dedicada a Ismael Rivera, «Maelo». ${ }^{179}$ (Escuchar en https://www.youtube.com/watch?v=LbN2azLxRYE\&list=RDt9gsjztx3f8). Cuando Rivera tenía 31 años y se disponía a emprender un viaje a los Estados Unidos fue detenido en el aeropuerto de San Juan, Puerto Rico, por transportar cocaína. Recluido en la prisión de Kentucky purgó cuatro años de encierro. La prisión es popularmente conocida bajo el nombre: «las tumbas», ya que está edificada por pisos de celdas subterráneos. Entre los puntos de interés de esta canción enumero, en primer lugar, la realidad de aquellos latinos que al intentar mejorar sus condiciones de vida, caen en las redes del tráfico de drogas. Al ser capturados son confinados en cárceles en sus propios países o extraditados a reclusorios estadounidenses. En segundo lugar se encuentra el inquietante estado de desasosiego que debe inundar al sujeto del goulag, en términos de Foucault, la condición de encierro que mina el ejercicio de la libertad y la voluntad de poder. El último, y muy aflictivo, punto de interés es que el protagonista e intérprete de la canción es el propio ex convicto.

\footnotetext{
178 «Las Tumbas», canción perteneciente al álbum Soy feliz, del sello Vaya Records, del año 1975.

${ }^{179}$ La historia de Ismael Rivera (1931-1987), al igual que en la mayoría de cantantes de salsa, está recorrida por situaciones adversas y trágicas. El origen pobre, la vida en la calle y la lucha por sobrevivir, conectada con el tránsito hacia Estados Unidos, son casi una constante en los intérpretes del género. No obstante, la relación con la música suele ser estrecha desde el comienzo, con la música que se escuchaba y se hacía en el barrio y las calles. Sobre este sonero el experto en música del Caribe César Pagano realizó una detallada y estructurada reconstrucción biográfica, consignada en el libro Ismael Rivera: El sonero mayor. Cito un pequeño aparte donde Rivera narra sus orígenes humildes en Santurce, Puerto Rico: «... en esa Calle Calma todo el mundo era albañil. Se llamaba Calle Calma, pero allí había tambores. ¡Calma era lo que menos había allí! Es una palabra bastante irónica: Calle Calma que además tenía al lado "EI callejón tranquilidad", que era un barrio de bomba y plena muy encendidas. ¡El alboroto se lo pueden imaginar!» (1993, 7-8).
} 


\section{Las Tumbas}

Pregón

¡Recoge m’hijo! Mira que vas pa' la calle.

Dile a Pancho que me mande algo pa' la comisaria.

Ave María títere, qué breike.

Coro

De las Tumbas quiero irme no sé cuándo pasará,

las tumbas son pa' los muerto’ y de muerto no tengo na’.

Estrofa I

Cuando yo saldré de ésta prisión

que me tortura, me tortura mi corazón;

si sigo aquí enloqueceré. ¡Suelta!

Estrofa II

Ya las tumbas son crucifixión,

monotonía, monotonía, cruel dolor;

si sigo aquí: enloqueceré.

Antes de abordar el elemento lírico del tema es oportuno mirar brevemente algunas características de la canción. La salsa erige su ámbito sonoro desde cierto tipo de cadencia urbana arrabalera; tal cual se observaba en el segundo capítulo. Evidentemente, la vocalidad de Maelo trae de suyo la síntesis sonora de la calle del barrio y las vivencias que ella comporta; en especial, la miseria. Pero hay un aditivo patente en el tono del tema consignado en la melancolía que arrastra. Tal melancolía puede ser constitutiva del intérprete debido a que es el relato de su experiencia en prisión. No se trata de un buen actor en un acto de fingimiento, es la corporeidad de Maelo encarnada en su voz. Cuando Maelo canta «Las tumbas» hay verdad en su vocalidad. ${ }^{180}$ Por extensión, cuando los oyentes conocen el contexto del tema, la historia, están potencialmente más facultados para «descifrar» los códigos inmersos en su vocalidad. ${ }^{181}$

\footnotetext{
${ }^{180}$ La verdad en la vocalidad no está sujeta a que el intérprete haya vivido la experiencia que refleja el contenido de una canción; pues el actor o el cantante pueden tener la verdad en su interpretación; bien lo expresan Barthes (1982) o Jarman-Ivens (2011). Simplemente, aquí coinciden la verdad y una experiencia de vida.

${ }^{181}$ En los estudios de intertextualidad los datos o información extras que facilitan la comprensión del texto son tomados como «referentes». Aunque este no es el caso de un estudio intertextual, el concepto de «lector competente» utilizado por López-Cano es muy adecuado para hablar sobre la habilidad del oyente en la identificación de los distintos componentes textuales de una obra: «el oyente establece relaciones de
} 
Puesto en claro lo anterior, se define que también la oralidad que estructura las líricas es una oralidad callejera. La señal más específica es el pregón inicial: «¡Recoge m’hijo!». Con un argot coloquial una voz imperativa solicita recoger las pertenencias, probablemente, del recluso que ya ha cumplido su condena y sale a la libertad: «Mira que vas pa' la calle». La proposición está matizada por el vocablo «m’hijo»; contracción del posesivo «mi»y el nombre «hijo»: mi hijo. Muy usada en la lengua popular latinoamericana y en especial en la Cuenca del Caribe. ${ }^{182}$ Denota un importante grado de cercanía y confianza con la persona a la que se dirige, aunque el registro depende del contexto y tono en que se diga. La siguiente contracción: «pa’la» es bastante usual en lengua vulgar; se diría que no es un lenguaje muy esmerado. Estos pequeños detalles de la lengua, entre otros, permiten apreciar la directa intervención del lenguaje popular en el pregón. El pregón es una parte especialmente habilitada para que el intérprete improvise con distintos registros de la lengua hablada y variados niveles de elaboración semántica.

De este modo, el soneo puede llegar a ser la característica principal por la cual se define la calidad del cantante, y muchos intérpretes han pasado a la historia del género debido a su alto desempeño en esa práctica. Es el caso, por ejemplo, de Ismael Rivera, conocido como «El sonero mayor», o de Héctor Lavoe presentado como «El cantante de los cantantes» o sencillamente «El cantante». En la salsa clásica el soneo es tan importante que prácticamente identifica al intérprete. ${ }^{183}$ César Miguel Rondón describe las cualidades de Rivera en las siguientes palabras:

Así como las innovaciones de Benny sirvieron para amoldar y representar el espíritu característico del son de los años cincuenta, asimismo la forma sonera de Ismael sirvió para representar el matiz de la salsa que a partir de los años sesenta arrasó con la región. Vista la expresión en perspectiva, el soneo salsoso no puede menos

\footnotetext{
parentesco entre momentos de varias obras estableciendo redes que colaboran en sus procesos de comprensión» (2007, 3). En el ejemplo de Rivera tener tal información sobre la historia del tema contribuye al desarrollo de lo que López-Cano llama las «competencias musicales» de los oyentes. En ese sentido descifrar los códigos de su vocalidad será una tarea mejor orientada en el oyente informado, que en el que no posee tales referencias.

${ }^{182}$ También se hace contracción del posesivo «mi» y el nombre en diminutivo «hijito», mi hijito, con el resultante «m’hijito».

${ }^{183}$ Mencionaba también en el capítulo 2.5, que en la salsa más moderna, denominada entre sus múltiples acepciones salsa balada, la improvisación no es importante y no define al intérprete. Son escasos los cantantes de esta vertiente reconocidos por su desempeño en la improvisación.
} 
que definirse con relación a Ismael, en función de él, porque fue él quien lo perfiló y proyectó sus posibilidades más contundentes. (Rondón [1978] 2007, 289-90). ${ }^{184}$

Por su parte, en los coros y las estrofas la estructura cuenta con otros parámetros. Hay una disposición rítmica en la métrica de los versos y una rima elaborada. Pongo entre guiones las sílabas y en negrita los acentos:

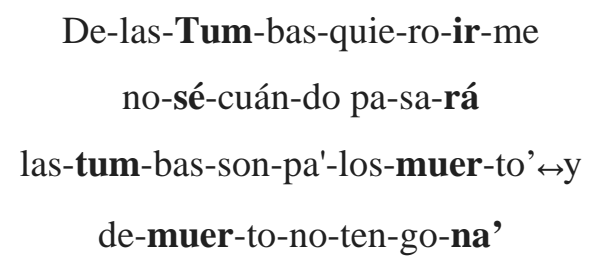

En los cuatro versos -octo y heptasílabos- la rima es asonante y la posición de los acentos en el verso coincide con las sílabas tónicas, lo que permite un buen movimiento rítmico en toda la estrofa. En cuanto a la elaboración de los versos puede observarse el uso enriquecido de recursos literarios; por ejemplo: el hipérbaton: 'De las tumbas quiero irme’ en vez de 'Quiero irme de las tumbas'. La metáfora: 'las tumbas son crucifixión'. El epíteto: 'cruel dolor'. Lo anterior para consentir en que hay una estructura poética, aunque de todas formas sea una poética callejera construida desde el sentir cotidiano. Como poética, no es la copia de la oralidad local en las letras, sino una construcción literaria más elaborada, fundada en la vivencia y el lenguaje urbanos; pero al fin, poética. Es decir, hay una estilización de esa oralidad evidenciada en la realización rítmica de los versos, en sus epítetos y sus metáforas, por lo cual es una estructura lírica.

Sobre el análisis de contenido de las letras pop realizado en la década del cincuenta por Donald Horton, ${ }^{185}$ que muestra la habitualidad con que los jóvenes utilizan las letras en los rituales amorosos, Frith señala:

\footnotetext{
${ }^{184}$ A propósito de la improvisación en el soneo, la apreciación de Rondón se reitera en el siguiente comentario de Peter Manuel $(2004,134)$ : «A pesar de que los solos instrumentales son los más elaborados, las improvisaciones de los cantantes solistas son igualmente sobresalientes. De hecho, los vocalistas latinos han sido a menudo directores y estrellas, bien sea por su talento musical o, como suele suceder hoy en día, por la imagen de estrella que proyecta sobre ellos la industria musical. Los vocalistas talentosos pueden ejercer un liderazgo musical a pesar de no tener conocimientos musicales teóricos. El ejemplo clásico es el cantante y director cubano Beny Moré (fallecido en 1963), quien, según palabras de Acosta, representaba "tres cuartos de la banda" $(1993,16)$ a pesar de no haber tenido una educación musical formal». El texto citado por el autor es: Acosta, Leonardo. Elige tú que canto yo. La Habana, Editorial Letras Cubanas, 1993.

${ }^{185}$ Frith cita la investigación que hace Horton sobre las letras amorosas de las canciones pop, que utilizaban los adolescentes norteamericanos. La considera de un serio y profundo análisis de contenido en la tradición sociológica americana. Fue publicada en los años cincuenta. Ver «Hacia una estética de la música popular» en Las culturas musicales. Lecturas de etnomusicología (Frith [[1987] 2008). El texto
} 
Los fans no idealizan a los cantantes porque deseen ser ellos, sino porque esos cantantes parecen ser capaces, de alguna manera, de expresar lo que ellos sienten; algo así como si a través de la música nos fuéramos conociendo a nosotros mismos ([1987] 2008, 424).

En efecto, la música popular es capaz de condensar todo tipo de emocionalidad. En la salsa el amor es apenas uno de los detonantes de la lírica. Como mencionaba anteriormente, en el género se expresan de particular manera el desamor y los múltiples estados emocionales que constituyen el sumario sentimental de cada persona. Por consiguiente, además de ayudar a expresar las emociones con un lenguaje más elaborado y asertivo, la salsa contiene la emocionalidad que se vive ante diversas situaciones de la vida personal y que no necesariamente se exponen al otro, sino que describen y explican lo que está sucediendo en el interior de una persona; las conmociones individuales de los sujetos. Esta especie de introspección se aprecia claramente en la realización lírica de «Las tumbas».

Sobre la misma temática «El Preso» de Wilson Manyoma Gil, narra en primera persona la experiencia del presidio en la Penitenciaría de Gorgona, ${ }^{186}$ reclusorio localizado en la isla del mismo nombre en el Océano Pacífico sur colombiano. ${ }^{187}$ Versión disponible en https://www.youtube.com/watch?v=DZ2hWplmioA.

\section{El Preso}

\section{Pregón recitado}

¡Oye! ¡Te hablo desde la prisión! Wilson Manyoma... Gorgona. ¡Y dice!

\section{Estrofa I}

En el mundo en que yo vivo siempre hay cuatro esquinas, pero entre esquina y esquina siempre habrá lo mismo.

Para mí no existe el cielo, ni luna, ni estrellas,

citado por el autor es: Horton, Donald. «The dialogue of courtship in popular songs». American Journal of Sociology 62, 1957.

${ }^{186}$ Resulta un poco extraño que análisis tan interesantes sobre las letras de las músicas populares en Colombia como el que presenta Egberto Bermúdez bajo el título «Las palabras de la música o la música de las palabras, Primera Parte/Segunda Parte'» (2005b), no contemplen las letras de la salsa dura colombiana como la referenciada en esta sección.

${ }^{187}$ La interacción de los intérpretes salseros con las prisiones mediante diversos conciertos en los reclusorios es descrita por Arteaga en los siguientes términos: «La continua relación del músico salsero con la delincuencia ha hecho que éste ubique como sitio de concierto a las prisiones. Tenemos así las constantes presentaciones de Los Hermanos Lebrón, El Conjunto Clásico, Rubén Blades y El Gran Combo en establecimientos carcelarios» $(1993,117)$. 
para mí no alumbra el sol, pa’ mí todo es tinieblas.

Estribillo

Ay, ay, ay, ay! qué negro es mi destino.

¡Ay, ay, ay, ay! todos de mí se alejan.

¡Ay, ay, ay, ay! perdí toda esperanza.

¡Ay! a Dios, solo llegan mis quejas.

\section{Pregón recitado}

Te hablo desde aquí Peter Infante. ¡Lleva ya!

\section{Estrofa II}

Condenado para siempre en esta horrible celda, donde no llega el cariño ni la voz de nadie.

Aquí me paso los días y la noche entera, solo vivo del recuerdo eterno de mi madre [...]

Nótese en el fragmento anterior que esta clase de narrativa recurre menos a figuras literarias del tipo metáfora, hipérbaton o epíteto que las presentes en «Las tumbas». La narración es también en primera persona, pero se elabora desde la idea de una crónica, como si fuera un diario. Sin embargo, la métrica de los versos no llega a convertirla en estructura narrativa, cuya forma se opone a la lírica. Se esmera en realizar una descripción de la realidad de la celda en un lenguaje más explícito. Expresiones como «En el mundo en que yo vivo siempre hay cuatro esquinas» o «donde no llega el cariño ni la voz de nadie» conforman de hecho una caracterización ${ }^{188}$ del mundo en el que vive el preso. Pero naturalmente, no un mundo de sentido; pues han sido otros quienes lo han construido para él. También describe el estado interior de la persona conmocionada ante la falta absoluta de libertad: «Condenado para siempre en esta horrible celda» o «solo vivo del recuerdo eterno de mi madre». El retorno a la madre es un aditivo diferente y anuncia la única solución posible al encierro, que inevitablemente conduce a la muerte. No obstante, la manera en que está escrito el texto es más prosa que poesía, pero ambas letras -«Las tumbas» y «El preso»- ayudan a refrendar la idea de que las canciones de la salsa pueden decir lo que la gente del común no puede elaborar virtuosamente en su lenguaje; en cierto sentido, decirlo «poéticamente».

\footnotetext{
188 En las estructuras prosaicas la descripción y la caracterización son recursos expresivos para la
} construcción textual. 
Otro arquetipo que describe la salsa en distintas formas es el del maleante; el que se gana la vida a expensas de robar al otro, que incluso puede ser su vecino. Es muy interesante estudiar esta narrativa puesto que, por norma, no se hace en primera persona; siempre es la representación del «otro»; no soy «yo» el maleante. Es decir, se narra al otro que sí lo es, porque yo como narrador, no lo soy, solo lo cuento. Podríamos incurrir en una reflexión moral desde esta posición, pero la idea es observar la cercanía de los textos al lenguaje coloquial, por un lado, y por otro, mostrar cómo la identificación se hace con el contexto de la delincuencia, pero también con el personaje mismo, el delincuente. La manera grácil en que suele ser narrado puede generar un sentimiento de simpatía o, aun, de paternalismo por parte del oyente. Presento a continuación fragmentos de dos reconocidas canciones: «Pedro Navaja» ${ }^{189} \mathrm{y}$ «Juanito Alimaña» ${ }^{190} \mathrm{El}$ primero, interpretado por Rubén Blades y el segundo por Héctor Lavoe. Pueden escucharse respectivamente en https://www.youtube.com/watch?v=Fhs7yO4tbY4 y en https://www.youtube.com/watch?v=iSHZQMuwUYY.

Pedro Navaja es un maleante de barrio bajo que en un día ordinario sale a ejercer su oficio. Mas solo encuentra a una mujer, prostituta, que buscaba igual que él ejercer su profesión y conseguir algo de dinero. Pedro la sigue sigilosamente alistando el arma blanca que porta siempre para tales menesteres. Cuando la ataca ella se defiende con un revólver que lleva consigo. Ambos mueren en el altercado y, excepto un borracho que caminaba por ahí, pareciera que nadie se percató de lo ocurrido, lo cual deja el hecho en el anonimato.

\section{Pedro Navaja. Rubén Blades.}

Por la esquina del viejo barrio lo vi pasar con el tumbao que tienen los guapos al caminar. Las manos siempre en los bolsillos de su gabán pa'que no sepan en cuál de ellas lleva el puñal. Usa un sobrero de ala ancha de medio la'o y zapatillas por si hay problemas salir volao.

Lentes oscuros pa'que no sepan que está mirando y un diente de oro que cuando ríe se ve brillando. Como a tres cuadras de aquella esquina una mujer va recorriendo la acera entera por quinta vez.

\footnotetext{
${ }^{189}$ Del álbum Siembra, producción de Willie Colón y Rubén Blades en 1978 bajo el sello Fania Records. 190 Composición de Catalino Curet Alonso, perteneciente al álbum Vigilante, grabado en 1982 y publicado en 1983. Producción de Willie Colón.
} 
Y en un zaguán entra y se da un trago para olvidar

que el día está flojo y no hay clientes pa'trabajar.

Un carro pasa muy despacito por la avenida,

no tiene marcas pero to'saben que es policía.

Pedro Navaja las manos siempre dentro’el

gabán mira y sonríe y el diente de oro vuelve a brillar. [...].

El barrio está inundado de múltiples personajes arquetipo del tejido social en la gran ciudad latinoamericana. «Juanito Alimaña» al igual que «Pedro Navaja», es otra fotografía del delincuente, del atracador, que a fuerza de oficiar tanto en el medio queda registrado en la memoria de la localidad y es representado y recordado no solo en las páginas del lenguaje, sino en diversos eventos de la cultura popular: el año viejo, los santos inocentes, el carnaval. Indefectiblemente, las letras de la salsa dibujan los arquetipos de los habitantes de la ciudad. Una ciudad moderna donde a la luz de la vivencia en grupo hay un reconocimiento de ese «otro» y lo que se sabe de su historia, al igual que se reconoce a ese «otro desconocido» por quien la comunidad se pregunta.

\section{Juanito Alimaña. Héctor Lavoe}

La calle es una selva de cemento y de fieras salvajes, cómo no, ya no hay quien salga loco de contento, donde quiera te espera lo peor. Juanito Alimaña con mucha maña llega al mostrador, saca su cuchillo sin preocupación, dice que le entreguen la registradora, saca los billetes, saca un pistolón.

Sale como el viento en su disparada, y aunque ya lo vieron nadie ha visto nada, Juanito Alimaña pa' la fechoría se toma su caña, fabrica su orgía.

La gente le teme porque es de cuidado, pa' meterle mano hay que ser un bravo, si lo meten preso sale al otro día porque un primo suyo 'tá en la policía.

Juanito Alimaña si tiene maña es malicia viva y siempre se alinea con el que está arriba y aunque a todo el mundo le robó la plata todos lo comentan nadie lo delata.

«Juanito Alimaña» sitúa su personaje en el complicado eje de la ciudad latinoamericana de la actualidad, cuyo barrio popular está identificado por unas estéticas arquitectónicas que propician, por defecto, un ambiente sórdido, apto para el crimen y sujeto al anonimato. La calle ya no es un lugar para compartir en comunidad y extender la vivencia de la casa. Ahora la calle es un lugar agreste habitado por el hampa; el ciudadano común tiene que estar pendiente de cuidar y defender sus pertenencias o la 
misma vida a toda hora. La canción es la fotografía del típico atraco al local y el delincuente es un habitante del barrio que goza de su mala reputación desde que era pequeño. Curiosamente, en la escena que pinta la canción, Juanito, viene triste del entierro de Pedro Navaja.

La representación de la delincuencia urbana en las liricas salseras del estilo Pedro Navaja, expone elementos familiares en la conformación del tejido social del barrio. Arteaga comenta: «Dos herederos directos de la narrativa de Pedro Navaja fueron Juan Cuchillo de José Fajardo y Juanito Alimaña, compuesto por el maestro Tite Curet Alonso y vocalizado por Héctor Lavoe, un sonero veterano en eso de cantarle al malandraje y al arrabal antillano. Juanito Alimaña trabaja en los mismo sectores que Pedro Navaja y bajo los mismos parámetros, sin embargo en Juanito Alimaña el protagonista no muere, dando a entender que un siniestro personaje como él puede aparecer en cualquier esquina y en cualquier momento» (Arteaga 1993, 131).

Las letras de la salsa marcaron un parangón importante con otros géneros de bastante auge en el momento; por ejemplo la balada romántica en español. La diferencia es ostensible con otros géneros, tanto en la manera de contar las historias como en los temas que abarcan. En cuanto a los temas, las líricas salseras encarnan una representación de las estridentes historias de la miseria y la violencia, el desamor, el infortunio, el despecho, la tristeza, la alegría o la nostalgia. Estas elaboraciones se presentan en un registro muy real y lejos de teatralizar la vida cotidiana, emergen como crónicas de lo que sucede en el espacio habitado y compartido por propios y por otros. Entonces, los oyentes reconocen en tales crónicas vivencias cercanas o propias que vinculan la escucha a la narración de tales experiencias. Recordar, revivir, identificarse e identificar al otro en las letras, forman parte de esta práctica de escucha. Wilson Córdoba, otro informante bogotano, abogado y melómano, comenta:

Un día mi tío me regaló un casete de Daniel Santos; como estaba enamorado, todas las canciones me coincidían y entendí que ése era el mundo latino, y que me reconocía como tal, como latino [...] Me sorprendió que aquellas letras narraran justamente las mismas vivencias que yo tenía (2014, comunicación personal).

En cuanto a la forma de contar las historias, aquella oralidad de la calle que porta la salsa permite que la gente común establezca identificaciones intensas con las canciones en tanto el vocabulario y la manera de relatar las historias son semejantes, en cierta 
manera, a la oralidad cotidiana. El lenguaje de los vecinos reproducido literariamente en las letras, por un lado, y por el otro, la manera en que los intérpretes dicen las letras, cuya particularidad es exactamente la cercanía con la forma común de hablar, interpelan a las personas suscitando identificación y representación al instante. La canción salsera no se funda sobre la figura de la persona que sobresale en el estadio social, político, histórico o cultural. Se funda, por el contrario, en la persona común, la que no es nadie, sobre aquella que solo puede encontrar eco en la representación. ${ }^{191}$ Los intérpretes consiguen que los «nadies» tengan voz y en un juego bidireccional e intersubjetivo, permiten que los «nadies» sean a la vez el cantante; el oyente se identifica con Lavoe, pero es también a la vez el «propio» Lavoe.

El pregón desempeña una función taxativa en la forma en que se dicen las letras. Al constituirse en una práctica improvisatoria demanda toda la habilidad lingüística que pueda tener el cantante en términos de agilidad, picaresca, doble sentido, significado connotativo. Tales habilidades están determinadas en el conocimiento de las prácticas de intercambio cultural en la vida de las comunidades populares que el intérprete es capaz de recrear en el transcurso de la improvisación. Si bien hay una poética de barrio en las letras de la salsa, que no es la copia de la oralidad local (no como se habla, se canta; cosa que sí sucede en el rap o el hip hop), en el pregón sí se reproduce la oralidad callejera: los llamados, los voceos, las interjecciones, el argot popular, la lengua vulgar, el dicho y el refrán. Claro, no es la constante, como se advierte en el elaborado pregón de «Aguanile» expuesto en el segundo capítulo de este documento, pero sí es la generalidad del ejercicio pregonero. También es importante aclarar que en ocasiones el

\footnotetext{
${ }^{191}$ A propósito de estos «nadies» que solo encuentran eco en la representación, tanto la narrativa literaria como la de la canción han logrado identificarlos y describirlos de múltiples maneras. Observo en el poema de Eduardo Galeano «Los nadies» cierta correspondencia con las descripciones de la salsa, aunque en un registro más dramático y desesperanzador, que se contrapone a la picaresca de los dos ejemplos citados: Sueñan las pulgas con comprarse un perro y sueñan los nadies con salir de pobres, que algún mágico día llueva de pronto la buena suerte, que llueva a cántaros la buena suerte; pero la buena suerte no llueve ayer, ni hoy, ni mañana, ni nunca, ni en lloviznita cae del cielo la buena suerte, por mucho que los nadies la llamen y aunque les pique la mano izquierda, o se levanten con el pie derecho, o empiecen el año cambiando de escoba. / Los nadies: los hijos de los nadies, los dueños de nada. / Los nadies: los ningunos, los ninguneados, corriendo la liebre, muriendo la vida, jodidos, rejodidos: / Que no son, aunque sean. / Que no hablan idiomas, sino dialectos. / Que no profesan religiones, sino supersticiones. / Que no hacen arte, sino artesanía. / Que no practican cultura, sino folklore. / Que no son seres humanos, sino recursos humanos. / Que no tienen cara, sino brazos. / Que no tienen nombre, sino número. / Que no figuran en la historia universal, sino en la crónica roja de la prensa local. / Los nadies, que cuestan menos que la bala que los mata $(2007,59)$.
} 
pregón recitado es una frase o un llamado del cantante que no está relacionado con la temática de la canción. ${ }^{192}$

Si observamos los siguientes pregones de la grabación más connotada de «Pedro Navaja» podremos identificar las características que se acaban de mencionar:

La vida te da sorpresas, sorpresas te da la vida ¡ay, Dios!: ${ }^{193}$

Pedro Navaja matón de esquina quien a hierro mata a hierro termina.

La vida te da sorpresas...:

Maleante pescador pa'el anzuelo que tiraste en vez de una sardina un tiburón enganchaste.

La vida te da sorpresas...:

Ocho millones de historias tiene la ciudad de Nueva York.

La vida te da sorpresas...:

Como decía mi abuelita: el que dé último ríe se ríe mejor.

La vida te da sorpresas...:

Cuando lo manda el destino no lo cambia ni el más bravo, si naciste pa'martillo del cielo te caen los clavos.

La vida te da sorpresas...:

En barrio de guapo cuidado en la acera, ¡cuida'o camará' que el que no corre, vuela.

La vida te da sorpresas...:

Como en una novela de Kafka el borracho dobló por el callejón.

El siguiente maleante narrado en el tema de Héctor Lavoe presenta cierta gracia en el desarrollo de su maldad. En un supuesto diálogo con el mismo intérprete le dice, por ejemplo: tumba aquí lo que tú quieras pues mi primo es policía. A la vez, el delincuente presenta bondades como la compasión, la solidaridad y la tristeza por otro compañero

\footnotetext{
${ }^{192}$ Sobre la improvisación del solista en el soneo y la elaboración del pregón en sí, Peter Manuel describe lo siguiente: «Este estilo, que consiste generalmente en frases de dos o cuatro compases que se superponen a modo de pregunta-respuesta, deriva directamente de la rumba tradicional, que a su vez evolucionó principalmente de sus predecesores africanos. Según algunos cantantes, la letra de los soneos debe estar relacionada con el texto o el tema de la canción, bien sea citando el texto de la guía o en versos originales (véase, por ejemplo, los comentarios de Miguelito Valdés en la obra de Salazar 1992, 11). Sin embargo, los vocalistas suelen cantar simplemente frases de repertorio sin ninguna relación, utilizando tradicionalmente un lenguaje coloquial (Gerard y Scheller 1989, 30-32)» (2004, 134-35).

${ }^{193}$ Para diferenciar mejor las secciones, escribo los coros en letra redonda y los pregones en cursiva.
} 
del oficio: ayer él iba muy triste y llorando así bajaba: vengo de un velorio, brother, el de Pedrito Navaja. Que si bien observamos es el otro personaje retratado en la canción de Blades. Relaciono los pregones del tema «Juanito Alimaña».

En su mundo mujeres, fumada, y caña atracando vive Juanito Alimaña:

Si el otro día lo encontré y guilla'o, él me decía: tumba aquí lo que tú quieras pues mi primo es policía.

En su mundo mujeres, fumada, y caña (ése es) atracando (ése es) vive Juanito Alimaña:

Oye... como alma que lleva el diablo se tira su disparada y aunque la gente lo vieron no lo ratean porque nadie ha visto nada.

En su mundo mujeres, fumada, y caña atracando vive Juanito Alimaña:

El rey de las fechorías ayer me dijo Facundo todo el mundo lo conoce, óyeme, en el bajo mundo.

En su mundo mujeres, fumada, y caña atracando vive Juanito Alimaña:

Mira, mírale las manos en ellas no tiene un callito ese nunca ha trabajado y siempre anda bien bonito.

En su mundo mujeres, fumada, y caña atracando vive Juanito Alimaña:

Oye, ayer él iba muy triste y llorando así bajaba vengo de un velorio, brother, el de Pedrito Navaja.

En su mundo mujeres, fumada, y caña atracando vive Juanito Alimaña:

Mira, la gente le teme al tipo porque el hombre es de cuidado díganme a quién en el barrio los chavos él no le ha tumbado.

El maleante, matón, atracador de barrio pertenece a un cuadro de tipologías considerable en la lírica salsera. Lo importante es que la interpelación de las letras aúna aquel sonido urbano arrabalero a la oralidad callejera y se manifiesta rotundamente en el pregón. Esto se puede apreciar a simple vista en la construcción textual de «Juanito Alimaña», «Pedro Navaja» o «Triste y Vacía». Al mismo tiempo, el encarcelamiento ha sido uno de los tópicos en la lírica salsera, y la visita de grandes personajes de la música, en especial, de los integrantes de la Fania All Star a diversas prisiones en Colombia y América Latina ha sido emblemática. El intérprete salsero no deja de estar presente, cara a cara con los rostros de los desprotegidos, los desamparados y, en resumen, los que han perdido todo. ¿Por qué las letras junto a la improvisación 
pregonera o sonera son fundamentales en la interpelación? Precisamente, porque son las historias que se viven en el barrio: delincuencia, desamor, santería, presidio.

No obstante, puede establecerse que la identificación con las letras avala dos dimensiones. La del discurso elaborado que dice con estilo lo que el lenguaje vulgar hablado no sabe expresar y, por otro, la del lenguaje vulgar que también tiene su lugar en la canción salsera, exactamente, en el pregón. Es en el pregón donde el oyente, que es un habitante corriente del barrio, ve reflejada su habla cotidiana en el decir o cantar del intérprete. Entonces, el montuno -sección responsorial coro pregón- es el encuentro entre la palabra «estilizada» de la elaboración salsera con el lenguaje vulgar del barrio. En el mano a mano entre el coro y el sonero, el coro representa la oralidad estilizada y el pregón se despliega en lenguaje coloquial. Así que los dos registros se conjugan para traducir la subjetividad del lenguaje callejero en la lírica del canto. Por lo que se puede sugerir que el canto salsero es una materialización de la subjetividad del melómano y una forma de realización personal. Este procedimiento es bastante especial en las músicas populares y, por el momento, aún muy poco estudiado.

\subsection{Personajes del barrio y representación. La decepción de Sofía}

El significado que para una persona posee determinada canción puede ir ajustándose a tenor de las contingencias y de la distancia temporal entre el ahora y el momento en que se haya escuchado. Además esa canción que marca una experiencia o un momento específicos de la vida de un oyente, pasa a ser una propiedad y adquiere un valor excepcional debido a su posición o influencia en la historia personal. Resalta aquí la interesante condición de la apropiación de la música, ya que en su condición de propiedad se instaura como un bien personal (aunque no exclusivo). Desde las prácticas de consumo musical y, en específico, de los artefactos que la portan, Julio Mendívil explica:

(...) el valor de un $\mathrm{CD}$, gracias al uso, puede aumentar considerablemente como un producto de consumo, es decir, cuando ha dejado de ser una mercancía y ha pasado a convertirse en un bien cultural individual ${ }^{12}$. Por eso, un análisis de la producción de valor en el tiempo del consumo no puede prescindir de una mirada empírica de las 
prácticas y las historias de vida que los consumidores vinculan con las canciones ${ }^{13}$ (Mendívil 2011, 11).

Acogiendo esta teoría podemos decir que cada persona tiene un repertorio de artefactos culturales que tienen trascendencia vital en su historia de vida. Claro, un acetato o un disco compacto tendrán una importancia considerable en la vida de cualquier persona amante de la música; sin embargo, hay que precisar que los estudios sobre el consumo, en especial el consumo cultural, referidos a la música, han de trascender su noción cosificadora sobre el objeto portable. Primero porque la habitualidad de su uso propende por la preservación en el tiempo y, luego, porque el significado que tiene el artefacto para cada persona puede modularse, ajustarse o cambiarse de acuerdo a sus necesidades y deseos o al desprendimiento o desapego hacia el objeto, suscitado por las distancias que se generan con el paso del tiempo.

Pero haciendo alusión exactamente a las historias de vida que los consumidores vinculan con las canciones, asunto que reditúa en el valor personal que cada uno otorga a «su música», quiero centrarme en un elemento constitutivo de la canción: el personaje que la inspira. El personaje representado que inscribe la temática y que llega a ser el primer parámetro de reconocimiento de la canción. Para esto me valdré del testimonio de Alexa Rodríguez, violonchelista y profesora, cuya historia muestra la intensidad de la identificación que sentía con el tema «Triste y Vacía». En éste, el personaje femenino es el protagonista de una intrincada decepción sentimental. La idea es observar con detenimiento la letra y el pregón que aunados en la vocalidad de Lavoe son una rotunda representación de la tristeza y la traición. En este tema el canto no describe en primera persona al personaje narrado sino que, a manera de un observador, de alguien que mira desde lejos y presiente la turbación del otro, describe a una tercera persona. Versión disponible en https://www.youtube.com/watch?v=rRHbB8jjU8c.

\section{Triste y vacía. Héctor Lavoe.}

A. Ella va triste y vacía llorando una traición con amargura, por aquél que le decía que era su amor y su locura.

Ya la vida le ha enseñado demasiado, cometer el mismo error no le interesa, los amores que ha tenido le fallaron y dejaron en el aire las promesas y dejaron en el aire las promesas.

A. $[. .$. 
B. Va tratando de lograr lo que ha soñado, aprovecha la experiencia de la vida.

Va olvidando sufrimientos del pasado, la calumnia y la mentira la castigan, la calumnia y la mentira la castigan.

A. $[\ldots]$

C. Pero en todo este pasaje de la vida ha sabido mantenerse con decencia,

aunque muchos habladores la confundan, aunque muchos traten de inventar con ella, aunque muchos traten de inventar con ella.

A. $[\ldots]$

Montuno [Coro - Pregón]

Ella va triste y vacía: En su rostro se comprenden los fracasos de la vida.

Ella va triste y vacía: La calumnia y la mentira y el desamor la castigan.

Ella va triste y vacía: Fue que to’ el mundo le falló y ella no lo merecía.

Ella va triste y vacía: Por fracasos de la vida.

Mambo [Sección instrumental]

Así es que muere un amor jay! que nadie comprendía.

Las promesas le fallaron,... los errores de Sofía.

Montuno [Coro - Pregón]

Ella va triste y vacía: A dónde irá la pobre gitanilla, flor marchita y desolada, pero que cosa le harían.

Ella va triste y vacía: Caminaba tan orgullosa y de su dolor nadie sabía.

Ella va triste y vacía: Mírala que linda viene, mírala qué linda va, a dónde se escondería.

Ella va triste y vacía: Yo la vi... llorando yo la vi.

Alexa relata que en su juventud, antes de terminar la universidad, estaba comprometida con su pareja de aquel entonces. Juntos habían decidido que después de culminar sus respectivas carreras profesionales formalizarían su relación. Pero de un momento a otro, él rompió con ella tras conocer a una simpática universitaria que además ostentaba una «mejor posición» socioeconómica. La vida de Alexa se desmoronó. No solo era el aceptar la ausencia de su prometido sino confrontar el desprecio y los celos a los que se sintió sometida; todo eso mientras daba la cara a la familia, los amigos y los compañeros de universidad. En su entorno las personas la veían con compasión o no sabían de qué forma actuar con ella; lo que los sumía en un verdadero estado de incomodidad o confusión. Eso terminó por derrumbarla anímica y físicamente y tuvo 
que desaparecer de la vida social y universitaria durante un periodo de tiempo considerable. ${ }^{194}$

Ambos estudiábamos en la misma Universidad. Y es que todos nos encontrábamos el viernes, fijo, y a rumbear. Entonces, empezaron a llamarme; y no contestaba, no le contestaba a nadie, yo era un solo llanto y depresión. Era una completa "Sofía": "Triste y vacía”, ésa era yo, me la pasaba cantando esa canción, jésa era: Mi Canción! [Risas]» (Rodríguez 2014, comunicación personal). ${ }^{195}$

La conexión con el tema era tan profunda y visceral que Alexa cantaba la canción todo el tiempo que le era posible: en la Universidad, en la misma calle, en el autobus; en cualquier sitio donde se encontrara podía tararearla o reproducirla mentalmente. Comenzaba con el bara bara báraba bam bam bam... de los trombones o caía desordenadamente en alguno de los versos: ya la vida le ha enseñado demasiado, cometer el mismo error no le interesa... Cuando llegaba a casa la escuchaba una y otra vez en el equipo de sonido; incesantemente, sin cansarse hasta que el sueño le ganaba la partida. Los primeros acordes del tema sincronizaban tanto su noción temporal con la música como el gesto ritualizado de duelo de su cuerpo. Los trombones eran el anuncio, el preludio de la tragedia, y la voz de Héctor contando y cantando su propia historia eran el caos definitivo. Escuchar la canción le hacía daño, pero ella sentía que debía desmoronarse y armarse una y otra vez, ése era el desarrollo de su enfermedad. ${ }^{196}$

\footnotetext{
${ }^{194}$ Alexa Rodríguez relata que abandonó sus estudios universitarios por el término de un año.

195 «Triste y vacía», también, del álbum Vigilante es una de las canciones más conocidas del repertorio de Héctor Lavoe. Compuesta por Luis López Caban, se publicó en 1983. Aunque la letra no contiene estrictamente el nombre de Sofía, Lavoe lo menciona en los pregones, que transcribo también con el resto de la canción al inicio de este subcapítulo.

${ }^{196}$ Mendívil alude al ritual que posibilita la repetición de la escucha: [...] si el disfrutar la música antes de la adquisición quedaba supeditado a la casualidad o al albedrío de otros, con la compra, los consumidores, pasan a decidir cuándo y en qué circunstancias han de escuchar la música adquirida. Por tanto, un aspecto sumamente importante de la domesticación de las mercancías culturales a nivel individual es asegurarse la reproducción de la recepción. Y justamente porque la repetición de la escucha genera una instancia ritual, es que ella crea las condiciones para desarrollar variantes al momento del consumo $(2011,10)$.
} 


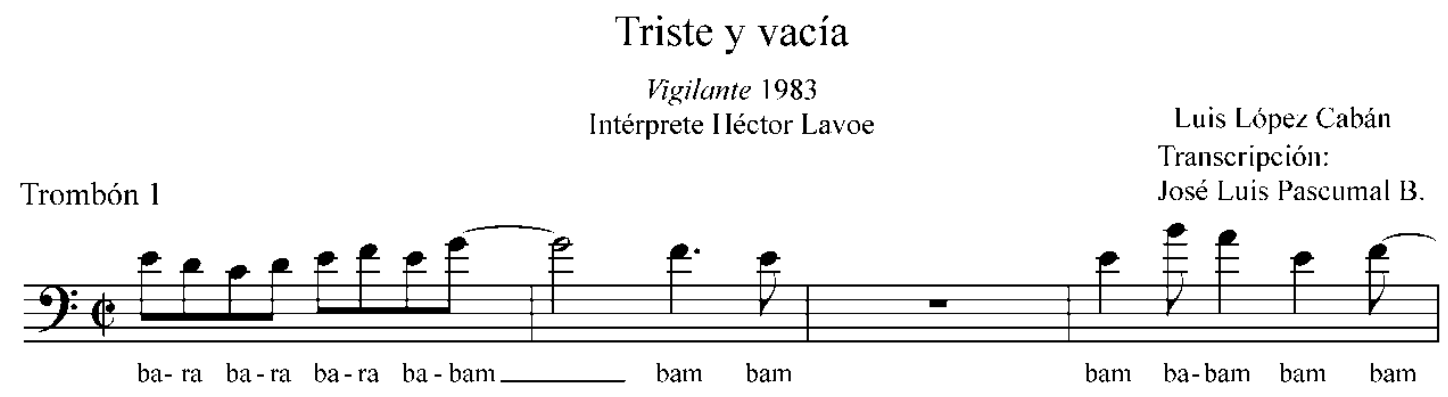

Figura 16 Triste y vacía. Introducción. Trombón.

Alexa muestra cómo ella se identificaba con Sofía gracias a la historia común en que se describen ambas mujeres. Definitivamente, Sofía es la representación de la condición de una mujer abatida, de un estado de ánimo, de una historia y, explícitamente, de la forma en que el «otro» mira a la persona victimizada en la trama. Cuando una de las funciones de la música como tecnología del «yo» es la construcción de una identidad, DeNora antepone que: «Uno puede también recordarse a sí mismo al volver a escuchar la música (por ejemplo, "como era esta música, así era yo también") y la música es un recurso clave para la producción autobiográfica y el hilo narrativo del yo» (2000, 158). ${ }^{197}$ Téngase en cuenta que Sofía ha sido construida por el narrador, es decir, entretanto la historia se relata en segunda persona, no es Sofía la que se canta a sí misma, es el autor-compositor de la canción quien ofrece su mirada sobre Sofía y es el intérprete quien la dibuja para el receptor. ${ }^{198}$ Así, Sofía se convierte en una de las inquietantes representaciones del «afuera», en términos de Foucault, y es a través de la representación que el mundo se nos hace inteligible. A través de la mediación de Sofía, Alexa se sintió construida en la canción, pese a que hay elementos distintos en cada historia.

Pero más allá del personaje retratado que media en la representación, hubo un papel fundamental en el proceso de interpelación: el intérprete. Alexa refería la forma en que sentía la historia en la voz de Lavoe: «Pues como él la canta, de esa manera tan triste,

\footnotetext{
197 «One can also recall one’s self on rehearing music (for instance, 'as this music happened, so did I') and music is a key resource for the production of autobiography and the narrative thread of self».

${ }^{198}$ De hecho es muy especial que el narrador que describe a Sofía sea un hombre; tanto autor como intérprete. Podría decirse que es una mirada de la tragedia desde la otra orilla, desde el otro bando o desde lejos.
} 
tan profunda... contaba exactamente lo que me estaba pasando». ${ }^{199}$ Esa tristeza en la voz de Lavoe que describe Alexa se conecta ágilmente con la nostalgia y la melancolía que percibe Hernando en «Periódico de ayer»; precisamente, ambos temas trabajan la decepción sentimental. Por lo tanto, en narrativas que tratan la desdicha del otro, el intérprete funge como un mediador entre el autor y el escucha; podría decirse que es él quien clausura el ciclo de la representación y consolida el relato con su manera de contarlo. Vemos entonces que el autor o compositor de la letra ha pasado a un último plano; ya no es trascendente en el relato, ya ha hecho su parte y no tiene interferencia directa en la interpretación de Alexa. Ahora es Alexa quien se traduce a sí misma desde la elaboración de la tragedia de Sofía.

En «La muerte del autor» Barthes enfoca, justamente, las funciones de la mediación en el relato. Aunque su apuesta es sustentar la muerte del productor mismo de la obra por cuanto al ser relatada por un tercero, sufre una transformación y, aún más, después pasa a ser interpretada por el otro que la lee, (en el caso de la canción, que la lee y la escucha) con lo cual el rol del autor queda anulado, nos brinda el argumento preciso para entender las formas en que un tercero mira, descifra o vigila al otro. ${ }^{200} 201$ En «Triste y vacía» el narrador describe a Sofía que llora y sufre y describe su relación con el mundo que la rodea. Cuenta también la evolución del personaje a lo largo de la vida:

199 El experto Ismael Carreño, citado en el capítulo anterior, coincide con la percepción de Hernando Gómez sobre cierta melancolía en la voz de Lavoe. Describiendo, a la par de esta característica, la genialidad de Louie Ramírez para componer y arreglar, comenta sobre este último: «Era todo un genio haciendo arreglos. Él fue el que le hizo el arreglo al «Periódico de ayer», le puso esos violines; el que le dio ese halo de nostalgia al «Cantante» cuando canta Héctor Lavoe y uno oye esa nostalgia de ese tema tan visceral: toda la música la concibió Louie Ramírez para hacerlo así, para que Héctor Lavoe lo cantara de esa manera, y lo cantara tan maravillosa, tan majestuosamente. Tanto que Rubén Blades, que es el compositor, después lo intentó cantar, y no; no tiene nada que ver. Y el «Periódico de ayer», otro. Todo eso, todas esas genialidades musicales, las concibió Louie Ramírez. [...]» (2014, comunicación personal). 200 En efecto, es tan personal la interpretación de Lavoe que muchas de sus canciones van perdiendo el referente de autoría de composición, arreglos o letra. Solo queda a flote su voz. Es emblemática la canción que le dedicó Blades, a la cual me refería anteriormente: «El cantante». La volvió tan suya, tan descriptiva que su público se acostumbró a esta versión. Anoto la primera parte de la letra: Yo soy el cantante que hoy han venido a escuchar. / Lo mejor del repertorio a ustedes voy a brindar. / Y canto a la vida de risas y penas, de momentos malos y de cosas buenas. / Vinieron a divertirse y pagaron en la puerta, no hay tiempo para tristezas, vamos cantante comienza.

${ }^{201}$ En el párrafo inicial de «La muerte del autor» Barthes introduce el origen de la referencia al otro de la siguiente forma: Balzac en su novela Sarrasine, hablando de un castrado disfrazado de mujer, escribe lo siguiente: «Era la mujer, con sus miedos repentinos, sus caprichos irracionales, sus instintivas turbaciones, sus audacias sin causa, sus bravatas y su exquisita delicadeza de sentimientos.» ¿Quién está hablando así? ¿El héroe de la novela, interesado en ignorar al castrado que se esconde bajo la mujer? ¿El individuo Balzac, al que la experiencia personal ha provisto de una filosofía sobre la mujer? ¿El autor Balzac, haciendo profesión de ciertas ideas «literarias» sobre la feminidad? ¿La sabiduría universal? ¿La psicología romántica? Nunca jamás será posible averiguarlo, por la sencilla razón de que la escritura es la destrucción de toda voz, de todo origen. La escritura es ese lugar neutro, compuesto, oblicuo, al que va a parar nuestro sujeto, el blanco-y-negro en donde acaba por perderse toda identidad, comenzando por la propia identidad del cuerpo que escribe (Barthes 1984, 65). 
Va tratando de lograr lo que ha soñado, aprovecha la experiencia de la vida. Va olvidando sufrimientos del pasado la calumnia y la mentira la castigan. Y son estos detalles los que dotan la historia de Alexa de la «exactitud» que ella atribuye a la canción.

En palabras de mi entrevistada, ciertamente tuvo que transcurrir demasiado tiempo para que pudiera escuchar la canción sin la aflicción tan profunda que le causaba y para que, de alguna forma, pudiera «gozarla» en lugar de sufrirla. En este punto es interesante observar la dinámica del significado de los objetos culturales; los significados no son estáticos están modulándose continuamente en la contingencia o en el transcurrir del tiempo. $^{202}$ Desde el testimonio de Alexa, además, fue interesante entender cómo la apropiación de la música en la experiencia estética propende por la elaboración y realización de un yo. El sujeto acude al artefacto para propiciar la performatividad que es imprescindible en el momento de construir una realidad; para el caso, construir la realidad de la tragedia y del duelo; elaborar aquel ritual por medio de la música. Dentro de la misma enfermedad de Alexa estaba la cura: desmoronarse y armarse con cada ejecución. Alexa tenía que ser Sofía, encarnaba a Sofía y en el juego intersubjetivo de los tres, incluido el intérprete, se desataba el caos y llegaba la calma; ritual repetitivo que fue crucial para elaborar y superar su consternación.

Haciendo eco al estudio de Pelinski citado en el primer capítulo de esta tesis, acerca de la mujer en el ritual inuit, se puede constatar que en ese espacio performativo en el que Alexa recuerda la música y la vivencia -la oye interiormente mientras camina en la calle, o la canta cuando llega a casa-, se va más allá de la mera representación. LópezCano (2013b) al acudir al componente semiótico de la experiencia muestra cómo se «modela un proceso simbólico y, por lo tanto, sustentado en signos, en donde lo "representado" no significa, sino que es». Por supuesto Sofía es de hecho una

\footnotetext{
202 Julio Mendívil en su artículo «The song remains the same? Sobre las biografías sociales y personalizadas de las canciones», reflexiona sobre el significado dinámico de las canciones a través de una experiencia personal con el tema «La vida es un carnaval», interpretado por la guarachera cubana Celia Cruz. En el artículo expresa que conoció la canción cuando estaba de moda; la bailó y la cantó al igual que mucha gente tras la ola comercial. Después, en 1999 visitó Perú, su país natal, con la circunstancia de haber sido apresado injustamente por el gobierno de turno de Alberto Fujimori. Señala que «la dictadura había decidido mantener el buen ánimo de sus presos. Así que, cada mañana, cuando el sol ofrecía sus primeros rayos, nos despertaba la voz vital y rumbera de Celia Cruz recordándonos, con bastante azúcar, que la vida es un carnaval» $(2011,3)$. De allí en adelante el tema se convirtió en su canción de la cárcel, al desplazar la asociación con la alegría festiva que tenía antes de la experiencia carcelaria.
} 
representación de Alexa, pero en la experiencia de escucha, en el ritual, es Alexa misma experimentando su identidad.

Al mismo tiempo y en adición a lo antedicho, López Cano afirma que la performatividad puede sustentar la construcción de discursos y narrativas, aunque muchas veces no todo lo simbólico de la experiencia pueda estar discursivizado y únicamente esté articulado con realizaciones corporales:

Pero también es muy posible que muchos otros aspectos de la experiencia subjetiva que yacen en el cuerpo residan ahí sin poder ser asimilados por baterías de información cognitiva o discursos verbales y su manera de presentarse a la experiencia sea sólo a través de la performance ritual efectiva (López Cano 2013b, 49).

En efecto, cuando Alexa introduce el tema del trombón con su canto, que es en sí la introducción de la pieza, las notas que componen el fragmento musical pueden suponerse parte de una trama simbólica que se ha articulado alrededor de su amarga experiencia. Advertir en el bara bara báraba bam bam bam las connotaciones que trae de suyo la canción -significado convencional de la decepción, las emociones de la tristeza, la traición y la soledad, la nostalgia en la vocalidad de Lavoe y otros hábitos interpretativos- más las circunstancias de la situación de la oyente, implica articular un todo simbólico, no verbalizable, que se pone en acción en la performance de su canto. Ella lo materializa a través de la voz y sabe que es el comienzo, el preludio de la tragedia, que únicamente se materializa en su cuerpo. En tanto integrante del cuerpo y de la corporeidad, la voz anuncia un vasto sistema semiótico que acciona una integración de subjetividades. Después, en el desarrollo de la canción, es la voz de Lavoe y es la voz de Alexa, integradas, indisolubles, el uno cantando al otro, y volveríamos a Barthes: una escucha que dice «escúchame», que en este episodio es a la vez la voz de un canto que dice «cántame». De esta forma, el juego intersubjetivo asocia a Lavoe, Sofía y Alexa y faculta que cada uno de los tres quede totalizado en el otro.

\subsection{Bogotá, caos y sentido: agencia de la salsa en una política del cuerpo}

"Quiero destruir este orden establecido que divide a la humanidad, hecha para estar unida, en pueblos enemigos, en poderosos y débiles, en ricos y pobres, que da a unos 
todos los derechos y no concede ninguno a los otros. Pues este estado de cosas hace que no haya en el mundo sino desdichados. Quiero destruir este orden establecido que transforma a millones de seres en esclavos de una minoría, y hace de esta minoría la esclava de su propio poder, de su propia riqueza. Quiero destruir este orden establecido que traza una frontera entre el disfrute y el trabajo". Richard Wagner. 1848. ${ }^{203}$

La cotidianidad bogotana está instaurada en la lógica del trabajo-casa-trabajo. Bogotá es una ciudad extralimitada en sus dimensiones geográficas y poblacionales para la capacidad real que tiene de resolver eficazmente los conflictos de espacialidad y movilidad en los que se ven inmersos sus habitantes. A esto se suma la situación de descomposición social que emerge a lo largo y ancho de la ciudad y que afecta directamente a la clase media y a las clases menos favorecidas que la habitan. Estas condiciones redundan en un estado de desorden cotidiano que impulsa unos ritmos alterados de vivencia y convivencia de lo urbano. Ante la rigidez de aquella lógica, el escucha salsero materializa un escape cuando transcurre el sonido. El escape se hace posible a través de la incorporación del movimiento físico o del canto, en los cuales el cuerpo funge como agente transgresor del orden establecido en la rigidez de la cotidianidad y, a la vez, como organizador del caos imperante. Cuerpo y movimiento físico se potencian ante la escucha de la salsa; es decir, la salsa agudiza la conciencia de tener un cuerpo, y el cuerpo salsero tiene una manera diferente de asumir el mundo.

Una de mis entrevistadas comenta en tono jovial, que no le es posible contenerse de tararear o cantar cuando en cualquier circunstancia cotidiana escucha o recuerda algún tema salsero: «Si me sé alguna de esas estrofas quiero cantar, jasí sea en el bus!» (Rosas Salazar 2014, comunicación personal). El cuerpo es lo que he construido y lo que se ha construido de mí, y desde esta construcción es también la reacción; es el catalizador del mundo que se afronta cada día. La pregunta por la construcción de un cuerpo salsero, es inescrutable. ¿Nos remite acaso a una «condición de corporeidad» en la que cualquier

\footnotetext{
${ }^{203}$ Este texto de Richard Wagner, es tomado de la traducción al español del libro francés Ruidos. Ensayo sobre la economía política de la música $(1977,23)$ de Jacques Attali, cuya primera edición francesa es de 1977. Attali cita el título del texto como L’art et la Révolutión y lo fecha en 1848.
} 
accionar del cuerpo en cualquier momento y circunstancia está, ya previamente, impregnado por un comportamiento arbitrado a través de la sonoridad de la salsa? O ¿tal vez refiere el «estado corporal» -y cuando digo «estado», asumo algo «transitorio»-, de un cuerpo salsero que se configura en el transcurso de la escucha que como bien advertí en el apartado sobre el «desplazamiento de la música», puede darse en el tiempo físicoobjetivo o en el tiempo psicológico-subjetivo?

Si en todo el recorrido de esta reflexión se ha consensuado y comprobado que en la performance de la escucha los cuerpos se performan guiados por la necesidad o el deseo e inmersos en la potencia sonora de la salsa, ello quiere decir que los sujetos son capaces de abastecerse de poder. La música otorga poder, y en la performance ritual y efectiva de los oyentes, el cuerpo es un cuerpo de poder. La pregunta que surge ahora es ¿Cómo se construye en la performance de salsa el cuerpo social? Para responderla será necesario recurrir a las siguientes consideraciones sobre el cuerpo en la música: Primero, la construcción del cuerpo en la escucha de la salsa. Segundo, la función transgresora de la salsa, en la que el cuerpo funge como un dispositivo de rompimiento de las estructuras establecidas. Tercero, la función organizadora de la salsa, donde el cuerpo elabora una realidad ordenada y afable. Los argumentos que se presentarán a continuación están sustentados, principalmente, en una lectura del texto de Pierre Bourdieu (1986), Notas provisionales sobre la percepción social del cuerpo.

Primero. La construcción del cuerpo en la escucha de la salsa. El texto de Bourdieu presenta el cuerpo como un producto social constituido por las relaciones que emergen en la cultura, el poder, la dominación y las distinciones de clase. El cuerpo ha desarrollado un lenguaje para decirse a sí mismo, así que la imagen que el otro percibe es una imagen construida que se ha «naturalizado» en la «legitimidad» del consenso social. Por lo tanto, se habla de una identidad natural que sobredetermina, por ejemplo, una vulgaridad o una distinción «naturales» en el cuerpo legítimo. En este lenguaje corporal se percibe que:

La distribución desigual de las propiedades corporales entre las clases se realiza a través de diferentes mediaciones tales como las condiciones de trabajo (con las deformaciones, enfermedades e incluso mutilaciones que el trabajo lleva consigo) y los hábitos de 
consumo que, en tanto que dimensiones del gusto, y por tanto del habitus, pueden perpetuarse más allá de sus condiciones sociales de producción (Bourdieu 1986, 184).

De aquí que se pueda leer, además, la trayectoria de los cuerpos en su imagen y su lenguaje y, al mismo tiempo, que se verifiquen y comprendan las diferencias de hexis ${ }^{204}$ corporal, de modo de estar y de comportarse, que circunscriben las relaciones con el mundo social «en la medida en que la relación con el propio cuerpo es, como veremos, una forma particular de experimentar la posición en el espacio social mediante la comprobación de la distancia que existe entre el cuerpo real y el cuerpo legítimo» (Bourdieu 1986, 184).

Este punto es el más interesante en el asunto de la experiencia musical: ¿qué papel juega la música en la experiencia de posiciones sociales?, ¿qué tiene que ver en el movimiento entre tales posiciones? Entonces, la salsa es vital para construir el sentido del cuerpo en lo social, un cuerpo que es real y no vana representación, aunque también sea representación. Ahora, con respecto a las categorías o posiciones sociales Pablo Vila sostiene que son el resultado de una constante lucha por construir y fundar el sentido. Es una lucha entre discursos que pugnan por determinar la «verdad». De esta manera, el sentido y la condición de verdad son elaboraciones discursivas, ante lo cual el autor argumenta «que la identidad social se basa en una continua lucha discursiva acerca del sentido que define a las relaciones sociales y posiciones en una sociedad y tiempo determinados» (Vila 1996).

Evidentemente, lo dicho es una verdad histórica y se constituye en simiente de las hegemonías. Pero si a una conclusión importante se ha llegado en los estudios de la identidad es que no todo está constituido discursivamente o que, en conclusión, la música constituye otro tipo de lenguajes o de discursos. Vila continúa:

[...] Por lo tanto, las diferentes posiciones de sujeto que convergen para formar lo que a primera vista aparece como un individuo "único y unificado" son en realidad construcciones culturales discursivas (entendiendo por discurso a las prácticas lingüísticas y no lingüísticas que acarrean y confieren sentido en un campo de fuerzas

\footnotetext{
${ }^{204}$ En La Distinción. Criterio y bases sociales del gusto, Bourdieu ([1979] 1998) asume la hexis como la estructura cultural incorporada en las personas a través del habitus. Así la hexis es la resultante del porte, los gestos, las maneras, la dicción y, en sí, el modo en que se presenta la imagen social del cuerpo ante los otros. Los habitus -palabra proveniente del latin hexis- se adquieren con el tiempo en concordancia con las prácticas de cada grupo o clase social: trabajo, juegos, deportes, danzas, poses, lenguaje, entre otros.
} 
caracterizado por el juego de relaciones de poder) (Laclau y Mouffe 1987); (Vila 1996). ${ }^{205}$

Pero las posiciones que se quieren revisar aquí son las que se originan en el cuerpo real al que apela Bourdieu, en la corporeidad, y que no pasan por el tamiz de la discursividad, las cuales son construidas precisamente en la vivencia musical. Ella nos hace tangible la construcción social del cuerpo, porque éste es examinado desde afuera; la aparición o exposición del cuerpo cuando sale de la intimidad de la casa, cuando es mirado, cuando transita por los distintos rincones de las calles, tal cual vimos en la decepción de Alexa, epígrafe 4.5, cuya tragedia se vitaliza netamente en la realización musical. Así que retomamos la pregunta inicial del subcapítulo: ¿cómo se construye en la performance de la salsa el cuerpo social? Y así volvemos a la vivencia de los melómanos en Bogotá, de la performance efectiva en la escucha de la salsa.

Cuando se entiende que en la rumba que acaece a la escena salsera de la taberna bogotana se acude a la «elaboración de la felicidad» hay que tener en cuenta que en principio es una realización personal; pues el baile es la encarnación de la libertad individual, donde la conciencia de poseer un cuerpo es absoluta. Pero no es un cuerpo que se posee como llevándolo o portándolo, como una vestidura, sino que es la subjetividad misma corporeizada, sin restricción alguna. A lo que se puede agregar: «Lejos de ser una realidad puramente mental, mi cuerpo propio es consciencia intencional vivida a través del cuerpo físico, pensamiento corporalizado, encarnado, que no se inscribe en el círculo de mis representaciones intelectuales (Welton 1998: 184; Crossley 2001a: 101)»; (Pelinski 2005, s.p.). Sin embargo, si en principio es una consciencia intencional, es decir, una realización personal, no se puede dejar de lado que los escenarios estésicos en la rumba son compartidos. Hay un espectador, una audiencia del nuevo yo transformado que asume un rol pasivo o activo en la escena. La presencia de un tercero coadyuva en la configuración del «afuera» que ha de constituir, en cierta medida, la subjetividad y porfía en el asentamiento de la nueva identidad.

En la escena de la rumba esa nueva identidad es una posición distinta del sujeto, definida en el encuentro con el otro, de tal forma que presento al exterior lo que he

\footnotetext{
${ }^{205}$ El texto citado por Pablo Vila es: Laclau, Ernesto y Chantal Mouffe. Hegemony and Socialist Strategy: Towards a Radical Democractic Politics. London: Verso, 1985.
} 
hecho de mi cuerpo y lo que la sociedad ha hecho de él. De conformidad con los argumentos de Bourdieu, Antoni Apiah sugiere que:

El problema de quién soy realmente se plantea por el hecho de lo que parezco ser: y aunque es esencial para la mitología de la autenticidad que ese hecho sea oscurecido por sus profetas, lo que parezco ser es en lo fundamental cómo aparezco ante los otros, y únicamente de manera derivada cómo aparezco ante mí mismo (Frith 1996, 213). ${ }^{206}$

Bourdieu reflexiona sobre la necesidad de tecnologías para intervenir el cuerpo y presentarlo en sociedad: cirugías, vestimenta, maquillaje. En concordancia con ellas, Charly Valencia dice al respecto de los bailes a los que asistía el fin de semana en los comienzos de su época rumbera, que fueron, en general, los de toda una generación: «Ya a los 15 conocí la primera discoteca, las agüelulos, las coca-colas bailables se llamaban, aquí en Bogotá. [...] El domingo reunía uno la mejor «pinta» y nos vamos a rumbear. Rumbear y descrestar: la mejor pinta, la mejor chica, eso era lo que mandaba» (Valencia Rivas 2014, comunicación personal). La «pinta» en Colombia significa el vestido, la ropa, unido al peinado y en el caso de las mujeres al maquillaje; todo en perfecta armonía. De acuerdo a la «pinta» se clasifica el estatus económico y social de una persona. Las características de la pinta son tan marcadas e identificatorias del estatus que enseguida se comprenden las diferencias entre clases. Hecho que refleja al mismo tiempo la infranqueable brecha social que abate al país.

Asimismo, en la escena de la rumba salsera toman parte «otros» que son capitales a la hora de elaborar el cuerpo social: la pareja de baile y quienes la observan. El cuerpo salsero se empodera en la performance logrando la conquista del otro y la admiración de la audiencia. Con lo que es preciso ser el mejor bailador: «Tú sabes, el que mejor baila tiene las mejores mujeres, siempre ha sido así. Ése es el don que tienen los rumberos. El buen rumbero anda bien vestido, tiene la mejor chica y no anda pelado» (Valencia Rivas 2014, comunicación personal). ${ }^{207}$ Ser el mejor bailador implica que el cuerpo tiene el mejor despliegue en la pista de baile. El cuerpo se libera y al compás del son realiza los movimientos más rítmicos y cadenciosos; con una soltura y desparpajo que debe

\footnotetext{
${ }^{206}$ El texto citado por Frith es Kwame Anthony Appiah. In My Father's House. Londres: Methuen, 1992.

207 Charly se inició en los oficios de la rumba a muy temprana edad, a sus 11 años, por lo que su experiencia data, en sus palabras, del año 75, 76, más o menos. En aquella época se escuchaba a Richie Ray, Fruko, Nelson Enríquez, Hennry Fiol, Papaíto, Gran Combo, Sonora Ponceña y ahí es donde empieza a conocerse más melodía. Las orquestas neoyorquinas, Mon Rivera, Charles Fox, Tito Puente, Tito Rodríguez, y empezó el auge de la salsa más dura.
} 
dominar la escena del momento. Pese a que haya un movimiento estándar, acorde con el estilo de la salsa o la música cubana, el baile no está sujeto a una secuencia ordenada de pasos, ${ }^{208}$ por lo que el bailador debe improvisar sin temor y debe saber incluir a su pareja en la improvisación. Para ello el bailador ha ensayado debidamente en casa, a solas frente al espejo o con un amigo o amiga al igual que con sus hermanas.

Tradicionalmente, la salsa es un baile de pareja en el cual es vivida la experiencia tanto conjunta como individual del baile. En el baile de pareja ambos integrantes son protagonistas. A través de esta práctica se «afina mutuamente» el conocimiento de ese otro que es la pareja de baile y no el simple espectador. Escuchar el sonido entre dos, cuyos cuerpos permanecen en contacto físico, y acordar tácitamente un movimiento conjunto al ritmo de la música, posibilita un juego de subjetividades en el cual los dos bailarines se comunican entre sí con el lenguaje corporal. En este juego intersubjetivo el cuerpo funge como verbo y puede encontrar tanto acuerdos como desacuerdos que se manifiestan en la armonía o desavenencia durante el desarrollo del baile. De esta manera, en palabras de Alejandro, «en el baile hay una comunicación cuerpo a cuerpo con el otro; eso no se da cuando uno está sentado en una mesa con el otro, hablando». Por lo tanto, en la corporeidad que transfiere la salsa en la performance del baile, se observa cómo el empoderamiento de los cuerpos actúa para que éstos se transformen en la pista de baile. Se puede cumplir entonces con el objetivo de conquistar a la pareja, de conseguir la atención del observador. En la performance de la rumba no hay «cuerpos alienados» reducidos a la «torpeza» sino «cuerpos con soltura», empoderados, construyendo la vitalidad de la escena y realizando la personalidad de un individuo.

Bourdieu ([1979] 2012) señala el cuerpo socialmente objetivado como un producto social. Por lo tanto, es un «cuerpo alienado» en cuanto su portador reconoce en el poder de la mirada del otro, las categorías de percepción y apreciación que le han sido asignadas por el orden social, y así su principal característica es «la torpeza». Sin embargo, en el momento de romper ese orden con el baile salsero, se convierte en un cuerpo «no» alienado que se establece en «la soltura» y rige desde ella su entorno. A las grandes discotecas o salsotecas bogotanas asisten toda clase de personas. Es muy llamativo ver en sus cuerpos sentados o de pie, su hexis corporal; es decir, la forma-

\footnotetext{
${ }^{208}$ Hago referencia al baile rumbero, no al baile experto de los concursos, donde todos los pasos son coreografiados. Bailar en este estilo rumbero, libre, como cualquier melómano que se abandona al disfrute corporal de la música, llegó a tener grandes desarrollos y grandes expertos. A este baile libre, le denominan «bailar a oído».
} 
postura de su cuerpo, que en palabras de Bourdieu es «la dimensión fundamental de la personalidad social» $(1986,191)$. En cambio, en el momento en que se disponen a incorporarse para bailar y comienza el llamado de la música -el sonido de los parches, la clave, los trombones-, se reelabora la hexis, lo que implica una reelaboración de su identidad «natural» en la performance del baile. El orden social se ha trocado y todos los cuerpos son ahora cuerpos legítimos. Porque el baile salsero es un baile de frenetismo o de cadencia, pero en ambos casos de liberación y seducción.

Fuera de la escena rumbera y en las labores de mi trabajo de campo en Bogotá visité la tienda de vinilos de colección Interdiscos, de Jacobo Vargas. En mi primer encuentro con Jacobo había un personaje sentado, curiosamente, en un taburete frente al mostrador principal. Rubio, blanco, de baja estatura, muy delgado y sumamente tímido. Su presencia pasaría desapercibida de no ser por estar frente al mostrador principal y de que Jacobo interactuara con él concediéndole protagonismo. Cuando llegué, acompañada de un par de amigos que le habían hablado de mi trabajo, nos reunimos a conversar. El personaje del taburete casi no participaba de la conversación, aunque estaba totalmente atento al desarrollo de la misma. Jacobo recordaba con entusiasmo los sitios privilegiados de la rumba salsera en los ochenta: El Palladium de la 13 con 54: «Eso era un potrero, yo presenté en el año 79 a Alfredo Linares, yo lo presenté. ... Duró 36 años». Al calor de la amena conversación con amigos y clientes que seleccionaban lo mejor de su abigarrada discoteca de acetatos, e intercalando algún trago de ron que compartía con los que estábamos presentes, la descripción de la escena salsera bogotana era inmejorable. De repente, se dirige al del taburete y me entero que es Jairo Villaruel, a quien se refieren por el sobrenombre de Pasofino. Reconocido en el medio por ser uno de los mejores bailarines profesionales de la escena de los años ochenta y, que en sus épocas, fuera gancho publicitario para diversas discotecas. Con la música de fondo, Jacobo le pide: «bueno, ¡hazte un picado ahí!» para que «comprendamos» el asunto salsero. Sin pensarlo dos veces Jairo salta del taburete y nos muestra con maestría cómo se desarrollaban los pasos y cómo se improvisaba para concluir en la naturalidad y sabor que tenía el buen baile viejaguardero, porque esa clase de bailarín, baila «al oído». A diferencia del baile moderno coreografiado, desarrollado sobre todo en Cali, que es más acrobático y pierde el sabor en figuras tan complejas, «la vieja guardia baila al oído y al piso». En ese lapso que no supera un minuto ya no es Jairo, es el personaje de la pista de 
los años ochenta, es por un minuto el Watusi bogotano; ${ }^{209}$ es quien gobierna la escena y se roba la atención de quienes lo rodean. Al terminar su acto Jacobo le interpela con simpatía: «Pero usted se ha achicado hermano!» y reparte otro ron extendiendo la charla 40 minutos más.

Así, quien no conoce a Jairo puede inferir que es otro humano cualquiera, mimetizado en la insignificancia del afuera; cabizbajo, pequeño y discreto, sin la fuerza suficiente para alterar la normalidad de la escena. Pero cuando salta a la improvisada pista de baile, ya no es Jairo, es Pasofino, Watusi, robando la atención y la admiración de todos los que lo rodean. Jacobo lo presenta como el «gancho publicitario» de las discotecas ochenteras, porque atraía ingentes cantidades de público por el show de su danza y porque todas las mujeres querían bailar con él. Luego, la manera cómo te ve y te identifica dicho espectador también juega un papel en el ahora performativo al influir sobre la manera en que se asienta y se establece la subjetividad emergente en el baile. Pelinski anota al respecto de la subjetividad y la intersubjetividad en la experiencia musical:

La experiencia musical cotidiana y subjetiva es, a la vez, una realidad social, -la "realidad suprema” sobre la que se fundan las estructuras intersubjetivas de sentido. En ellas vivimos y en ellas podemos reinterpretar nuestras interacciones con la música. Según Schütz, el público de un concierto “afina mutuamente” sus relaciones sociales en cuanto comunidad de oyentes, que a través de la música, crea prelingüística y preconceptualmente un "nosotros” (2005).

Segundo. La función transgresora de la salsa. La idea de entender el cuerpo salsero como dispositivo de rompimiento de las estructuras establecidas tiene lugar en el uso de la salsa para dislocar el orden en escenarios urbanos, exteriores e interiores, como las calles o los autobuses y las oficinas. Attali afirma que la música es el lugar histórico de la subversión, invirtiendo su argumentación en lo que a la vivencia corporal le atañe. Si bien trata acerca de antiguas formas de exclusión y esclavitud en las cuales el ritual de la música fue escape y a la vez organización de fuerzas, hay que entender que estas formas van mutando su apariencia para cambiar el significado original, pero en el

\footnotetext{
${ }^{209}$ También en Cali se conoce a un Watusi, de apellido Rivas, inmortalizado en la cultura popular del baile como uno de los grandes, por su estilo y por ser ganador de múltiples campeonatos nacionales e internacionales.
} 
fondo, el sometimiento y la dominación han pervivido en discretos y sofisticados aparatos aún en las sociedades actuales:

La música es el lugar de la subversión, trascendencia del cuerpo. En ruptura con las religiones y los poderes oficiales, esos ritos reagrupan, en los calveros o en las grutas, a los marginados: mujeres, esclavos emigrados. La sociedad los tolera a veces, o trata de integrarlos en la religión oficial: pero, de tiempo en tiempo, los reprime muy brutalmente: hubo en Roma un célebre caso que acabó con centenares de condenados a muerte. Actividad de masas por excelencia, la música es, con la locura, a la vez amenazante y fuente necesaria de legitimidad, riesgo que todo poder debe correr intentando canalizarla (Attali 1977, 26).

Hay una estridencia propia del sonido salsero manifiesta en: primero, la potencia de los metales (trompetas y trombones) cuya tímbrica está afectada por lo que en el medio musical salsero se denomina “sonar sucio". ${ }^{210}$ Segundo, la fuerza y variedad tímbrica y rítmica de la percusión (tambor, tumbadora, timbal, congas, bongó, campanas, güiro, claves y otras percusiones menores) con claras influencias africanas. Tercero, la disonancia natural de la armonía (segundas, séptimas, novenas propias del estilo). Aunque, quizás, este sonido rompedor salsero encuentre su mayor característica en la forma rítmica que se funda en los contratiempos y la síncopa resumidos en la clave; algo cuya resultante es coloquialmente denominada el tumbao. ${ }^{211}$ Esta aglomeración de detalles causa un impacto auditivo que interpela inmediatamente a los oyentes, pues es una resultante sonora muy contrastante con la música que normalmente se escuchaba en la radio de los ochenta: baladas románticas, baladas americanas en inglés, rock, música tradicional colombiana, entre otras. Ahora, no se trata de desvirtuar los procesos de consumo que tuvieron en dicho momento estas músicas y que en cierta medida y espacios siguen exhibiendo, sino que el sonido salsero rompió con esos esquemas y, en ese sentido, debe entenderse como algo que impacta un modelo o un canon auditivo.

\footnotetext{
${ }^{210}$ Podría describirse el sonido «sucio» como aquel que se emite con bastante aire y, de cierta manera, aquel que carece de la redondez tímbrica y colorística del sonido sinfónico. Es un sonido metálico y brillante que tiene como uno de sus máximos exponentes los trombones legendarios de Mario Bauzá o, más recientemente, Willie Colón. De hecho, el sonido de los dos trombonistas se ha convertido en un modelo en la ejecución de los metales y los dos intérpretes son referentes de estudio para los instrumentistas.

${ }^{211}$ El tumbao de la salsa puede definirse como la forma métrica afectada por la síncopa constante y en sí por las diversas claves que soportan las estructuras del son, o la rumba, por ejemplo. El término también se encuentra asociado a la manera de moverse, bailar o incluso a la manera en que una persona camina. Véase la canción «La negra tiene tumbao» del año 2002 interpretada por Celia Cruz.
} 
Al mismo tiempo, aquella sonoridad rompedora contagia las voces salseras. No de la misma manera, no todas obedecen a un estilo. Ciertamente, la hibridez del género procura una gama extensísima de tímbricas y vocalidades. En los subcapítulos 4.1 y 4.2 anotaba algunos rasgos de la vocalidad que articulados en un completo mecanismo sígnico, irrumpían en las subjetividades de los oyentes y, por ende y de manera muy personal, en las performances identitarias. La cuestión es que la totalidad del sonido salsero es el soporte que el melómano utiliza para dislocar el orden, en un ejercicio de poder que le permite poner resistencia a los intentos de dominación. Pero Foucault nos advierte acerca de lo siguiente:

No considerar el poder como un fenómeno de dominación masiva y homogénea de un individuo sobre los otros, de un grupo sobre los otros, de una clase sobre las otras; sino tener bien presente que el poder, si no se lo contempla desde demasiado lejos, no es algo dividido entre los que lo poseen, los que lo detentan exclusivamente y los que no lo tienen y lo soportan. El poder tiene que ser analizado como algo que circula, o más bien, como algo que no funciona sino en cadena. No está nunca localizado aquí o allí, no está nunca en las manos de algunos, no es un atributo como la riqueza o un bien. El poder funciona, se ejercita a través de una organización reticular. Y en sus redes no sólo circulan los individuos, sino que además están siempre en situación de sufrir o de ejercitar ese poder, no son nunca el blanco inerte o consintiente del poder ni son siempre los elementos de conexión. En otros términos, el poder transita transversalmente, no está quieto en los individuos $(1979,143-44) .{ }^{212}$

De esta forma, la salsa permite gestionar el poder en aquellas micro-estructuras cotidianas, donde, en teoría, todo se halla organizado. Foucault señala: «todos tenemos algo de poder en el cuerpo», poder que se acciona en la escucha y la performance. En el epígrafe 3.6 Desplazamiento de la música en la re-creación y reproducción de la salsa, se advierte que cuando suena la música el oyente realiza un re-producción corporal del sonido; diríamos una traducción corporeizada de aquello que escucha interior o exteriormente: se mueve; realiza operaciones físico-motrices como chasquear los dedos, mover la cabeza, balancear el tronco y las caderas, percutir en la mesa o el piso,

\footnotetext{
${ }^{212}$ En el subcapítulo 3.3 se analizaba el entorno del baile salsero para el joven que apenas estaba comenzando su vida pública; y se veía de qué forma el baile constituía una obligación para socializar, aun cuando no fuera del agrado de la persona. El baile daba estatus y por lo tanto mejoraba las posibilidades de conquista del sexo opuesto. En cambio, no bailar restringía las posibilidades de contacto social y aumentaba las de exclusión. Ésta es otra muestra del tránsito del poder, a cuyo paso unos someten y otros son sometidos, en estructuras tan elementales como la socialidad de los jóvenes en el baile.
} 
moverse en la silla del escritorio y, si se encuentra de pie, posiblemente, desarrollar algún paso de salsa siempre que se lo permita la dimensión del espacio en el que se encuentra o por donde transita: la oficina, el corredor, cualquier sitio en el trabajo o, como se apreciaba antes, en el interior del autobús en el cual todo es un caos en las horas pico del transporte urbano. Sobre estas acciones, el otro que intenta controlar no tiene dominio y no puede gobernar, mas esto no quiere decir que la salsa accione un poder que todos tenemos democráticamente distribuido, sino que es una prueba de la circulación del poder, parafraseando a Foucault, desde sus mecanismos infinitesimales, a partir de los cuales arranca su trayectoria ascendente para luego constituirse en mecanismos más generales y formas de dominación más extensivas, globales.

Tercero. La función organizadora de la salsa: elaboración de una realidad ordenada y afable. El asunto del transporte público masivo en Bogotá es uno de los ejemplos más fehacientes del caos ingestionable que promociona el establecimiento. Antes y después de llegar al lugar de labor, transcurren tangencialmente los periodos de desplazamiento. El transportarse en Bogotá resulta sumamente tedioso: buses repletos hasta colapsar en horas pico, atascos interminables, «compañeros de viaje» sospechosos o indeseables, y cualquier suerte de situación desafortunada. En estas circunstancias adversas el cuerpo agencia el orden y el sentido. El salsero canta o tararea mental o físicamente, mientras escucha los temas o emisoras elegidas para ese momento. En este trance sonoro-corporal elabora una situación «organizada» donde los componentes de la realidad son relocalizados para dar paso a la extinción del caos. En el tránsito de un lugar a otro, inmerso en el sonido salsero, el sujeto tiene la situación bajo control y ha impedido ser molestado. Una lectura más aguda diría que sigue agenciando una disrupción del orden establecido, puesto que este caos del transporte es una breve muestra de los mecanismos que necesita el sistema para urdir sus estructuras de sometimiento.

Cuando María va en el autobús, del trabajo a su casa o viceversa, y escucha por casualidad, o re-crea, alguna canción salsera, no reprime el placer de cantarla y de incorporar algún movimiento (Caso expuesto al comienzo de este epígrafe). Pero el gesto no proviene de una reflexión previa que la invita al acto; simplemente, en ese momento sucede, revelando el funcionamiento prototípico del continuo adentro-afuera de la mente. María se impone al orden establecido y en vez de subyugarse a las limitaciones que le impone el sistema de transporte, modelo a pequeña escala del 
sistema opresor de establecimiento, se desvincula de la estructura que impera en el apretado espacio del vehículo, mientras a ella vienen el piano y las trompetas del «Jala jala» y entra Bobby Cruz cantando: En Puerto Rico la gente goza más el jala jala, sabroso de verdad, y a todo el mundo quiere jalar pa' lla. ${ }^{213}$ Entonces, es claro y rotundo que la salsa configura cuerpos con soltura en registro real. María se ha impuesto al sistema en una realidad no ficcional, que se repite y se establece tantas veces sea necesario o conveniente en el entorno en que circula el melómano.

En cuanto a las tediosas jornadas laborales, el movimiento físico originado a partir de la escucha de la salsa (el cantar también sin que el contenido de la letra importe) transgrede, rompe, disloca la linealidad del espacio tiempo y de la organización imperante del lugar de trabajo, -quizás también de la casa- o el periodo de tránsito entre los dos (puesto que el moverse, el cantar o el bailar ante el sonido físico o interno, contraviene el entorno en tanto altera a quien lo produce como a quien lo presencia). La irrupción del cuerpo, mediada por el sonido salsero, no se ejecuta desde los bordes, desde la exclusión; es una irrupción en el epicentro mismo de la vida socio-laboral. ${ }^{214}$ En este lugar de transgresión convergen todos los componentes de la lógica sociolaboral: el trabajador, los compañeros, los jefes, los subordinados, la autoridad, el quehacer, la socialización con los colegas, los conflictos cotidianos, la comunicación con el otro, el trasladarse hacia diversos lugares dentro de la oficina, el desplazamiento hacia el trabajo y hacia la casa, los medios de transporte, el «otro desconocido» que va en el mismo autobús o comparte la acera, el sistema de transporte, las estaciones y las calles. De esta manera la transgresión corporal puede ser tan circunstancial como transitoria, por lo que rompe la lógica socio-laboral eficaz y contundentemente, ya que al no producirse en los espacios marginales de la ciudad, en los cuales siempre se esperan expresiones disruptivas, su interferencia puede ser más contundente.

Me canto las salsas que más me gustan y a pulmón [...] A veces me pasa esto: entro al súper y está sonando salsa y se me queda la canción, entonces salgo a la calle y empiezo a tararearla [Claudia tararea y aplaude para mostrarme] y de pronto, empiezo como a

\footnotetext{
${ }^{213}$ Como mencionaba en el subcapítulo 2.3, el usualmente denominado «Jala Jala» es una pieza de Bobby Cruz y Richie Ray que adquirió mucha popularidad a finales de los años sesenta. El nombre completo de la pieza es «Richie's jala jala» y forma parte del álbum Jala jala y Boogaloo publicado por primera vez en el año 1967. Disponible en https://www.youtube.com/watch?v=mRYvmj8_63c.

${ }^{214}$ Lo socio-laboral es entendido en esta tesis como aquello que sucede en el lugar de trabajo y también en el espacio geográfico-temporal que circunda y transcurre tanto en la llegada a ese lugar como en el regreso hacia la casa al terminar la jornada.
} 
moverme, y yo digo «estoy haciendo el oso». En la oficina me pasa mucho. Me conecto con mis audífonos y estoy trabajando y itan! Suena algo, me desconecto de lo que estoy haciendo y comienzo a moverme, entonces, ¡tan! Saco la mano, y mis compañeros saben que yo soy de ese rollo, de la salsita, y se mueren de la risa. O, perfectamente, estoy trabajando y suelto lo que estoy haciendo y comienzo a darle: pum, tan tan tan tan [Claudia aplaude al ritmo del tarareo], ellos se ríen pero es algo que yo hago automáticamente (Forero 2015, comunicación personal).

Como se puede apreciar, son batallas por el sentido; el sentido de una realidad que tiene que ser ordenada y amigable. Son batallas que no se dan únicamente en grandes unidades tempo-históricas. Hay micro-unidades socio-temporales en las cuales los sujetos pugnan también por construir y explicarse a sí mismos la realidad. Y es justamente en esta medida menor de temporalidad y en estos espacios socio-históricos de dimensiones más sutiles que la gente vive día por día, donde se libran pequeñas o imperceptibles batallas por el sentido y donde se percibe el flujo del poder. Además, no debe olvidarse que el salsero está localizado en la metrópoli latinoamericana, la cual resume y condensa todas las desigualdades que acarrea el capitalismo salvaje. Ante la impotencia del ciudadano común, el salsero se edifica en el sonido y las líricas como medio de expresión y de resistencia al sistema.

Si bien es cierto que la lucha discursiva acerca del sentido que define las relaciones sociales y las posiciones en una sociedad y tiempo determinados se verifica históricamente, las micro-luchas cotidianas pueden pasar inadvertidas debido a que no tienen un respaldo conceptual y lingüístico; son pre-discursivas. La música más que discurso es experiencia. A raíz de esto, hay luchas cotidianas que se libran con la experiencia musical y que pese a su micro-dimensión operan activa y eficazmente en la construcción de escenarios, la constitución de posiciones sociales y la configuración de subjetividades. En consecuencia, en estos procesos se evidencia la circulación del poder y se verifica que la música funciona como artefacto que lo acciona y lo gestiona. 


\section{CONCLUSIONES}

Las distintas relaciones construidas con la salsa por los sujetos que sirvieron a esta investigación permiten verificar un repertorio extenso y singular de las formas en que se han edificado mundos de sentido y significado a lo largo de sus vidas; los cuales giran alrededor de un elemento fundamental: la producción de identidad y subjetividad. Al respecto, la presente tesis da por sentado que la identidad y la subjetividad que se operan en el melómano salsero son fenómenos vinculados imprescindiblemente al cuerpo; por lo tanto, lo que corresponde a la salsa son las maneras en que su música ha permitido la elaboración de un sujeto y de un cuerpo, tanto en la experiencia de corporeidades emergentes como en el transcurso de la vida cotidiana en el terreno social y público. De esta forma, se ha contribuido a demostrar que la experiencia en la escena de la salsa estudiada ha sido vital para generar en sus participantes el sentido de un cuerpo que es real y no simplemente vana representación de estereotipos culturales o mero recipiente de una conciencia; conjetura, esta última, que reitera la segmentación cartesiana mente-cuerpo.

En las anteriores reflexiones han tenido eco teorías acerca de las funciones de la música popular urbana en la recepción y se han recogido, entre otras, las siguientes cuestiones: los estudios sobre música -material por excelencia de la emoción- en relación con la constitución del yo (DeNora 2000); la identidad como asunto de proceso y la capacidad interpeladora de la música en la experiencia identitaria (Frith [1987] 2008; 1996); los significados en tanto negociaciones y articulaciones de sentido atravesadas siempre por el contexto (Middleton 1990) o la experiencia performativa como realización no ficcional del «yo», en la cual lo simbólico tiene una participación dinámica (Pelinski 2005; López Cano 2013b). Asimismo, se han analizado aspectos referidos a la identidad en la era global exhibiendo la estrecha conexión que la música tiene con ellos, entre los cuales destacan, la identidad múltiple del sujeto postmoderno y el potencial de la noción de identificación (Hall 1992a; 1996a), la conciencia en torno al fluir del poder por todos los estratos sociales (Foucault 1979; 1988) y la construcción social de los cuerpos (Bourdieu 1979; 1986).

En la salsa escuchada por los sujetos investigados en esta tesis se advierte la crisis de los sistemas de significación, ya que dicho género musical enfoca un habitante 
latinoamericano inmerso en un flujo constante de inmigración, hibridación, apropiación, re-localización y búsqueda de realizaciones. De allí que la vitalidad y fuerza de la salsa faciliten superar el concepto de artefacto cultural limitado a su materialidad y la conviertan en un reflejo de la postmodernidad. Las resonancias de la salsa con el modo de ser -caótico- de la ciudad y con las interacciones de las personas y los grupos en el entorno urbano, implican que las relaciones tejidas alrededor del sujeto, los grupos y las instituciones, se desdibujen, se actualicen y se reconfiguren en un ritmo incesante. El melómano necesitaba -y necesita- establecer sus propios escenarios de control y de poder para dar sus batallas por el sentido y la salsa ha ayudado activamente a alcanzar ese fin; no solo porque en la libertad y el goce salsero se producen espacios simbólicos y reales en los cuales transita a satisfacción el cuerpo, sino porque además ello ha permitido la gestación de nuevos fenómenos de significado.

He inscrito dichos fenómenos de significación e identificación en tres ejes clasificatorios que se fueron evidenciando durante el recorrido etnográfico de este trabajo: primero, la construcción teórica y el ejercicio en torno al conocimiento del género musical; segundo, la realización emocional y corporal de la libertad y la felicidad; y tercero, la performatividad y producción de subjetividad. Se explican de la siguiente manera:

\section{Construcción teórica y ejercicio en torno al conocimiento.}

La salsa neoyorquina ocasionó una inusitada curiosidad por su repertorio, por sus raíces culturales e históricas y por lo que representaba en sí misma en el seno de la industria musical estadounidense y latina. Entonces, el fenómeno musical, en tanto suceso cultural, tuvo dos desarrollos notables en el ámbito de los seguidores y estudiosos: En primer lugar, la consideración teórica de la salsa como un encuadre histórico cultural y en segundo, la conformación de tipos de erudición salsera.

1. La salsa como marco histórico-cultural. Los salseros que se afianzaron en el conocimiento y se convirtieron en expertos observan en la salsa algo más que una recopilación de temas y aires inspirados en el Caribe; para ellos, -lo verifiqué a veces con algunos músicos- es algo que excede el género musical o la etiqueta de la industria cultural. Lo que ellos advierten en el devenir de la salsa es un movimiento humano, 
localizado geográfica y temporalmente, con dimensiones culturales e históricas más complejas. El encuadre histórico que determinan implica la zona migrante latina de Nueva York y el Caribe pero incluye Latinoamérica en su totalidad; encuadre que abarca un periodo aproximadamente reconocible desde la década de 1930 hasta la de 1980 (periodo correspondiente al impulso radial en la zona y a la decadencia de la salsa viejaguardera respectivamente).

Como consecuencia de ese marco histórico cultural, los salseros expertos adhieren los géneros vallenato, bossa nova, tango o cumbia a la vasta representatividad de la salsa. Si algo tienen en común esas expresiones son las raíces identitarias de donde se producen, y muchas veces son presentadas como músicas «regionales» o «nacionales». Por lo tanto, el pretendido ideal de latinoamericanidad en la salsa se afianza en tales orígenes para circunscribir en ella un abanico omnicomprensivo en el que converja un ideal de latinoamericanidad. En principio, dicho ideal era únicamente "pan-caribeño», pero después, y en el ámbito del salsero experto que refiero (esta aclaración es obligatoria), se extiende a un ideal de latinoamericanidad. Desde otro ángulo, el melómano usual no experto (es decir, el rumbero o el oyente promedio), considera que la salsa proyecta una comunidad -imaginada- de lo latino solo en el área caribeña (incluida Colombia), mas no en el resto de Latinoamérica. De ninguna forma incluye en la categoría de la salsa géneros musicales tan popular y musicalmente identificados como el tango o la bossa nova.

2. La erudición salsera. En segundo lugar, se constató la conformación de tipos de erudición. Hubo melómanos que querían superar la afición de escuchar o bailar salsa y comenzaron a buscar información en las primeras fuentes asequibles. Aunque los discos de vinilo consignaran datos elementales -producción, ritmos, instrumentación e intérpretes- y aparecieran otros en libros y programas radiales, la información era escasa, por lo cual el saber se volvió un asunto de destreza y competitividad. El nivel de conocimiento sobre la salsa, la música cubana, puertorriqueña y caribeña, en general, empezó a repercutir en el prestigio del melómano. Conforme fue alcanzando notoriedad, éste ostentaba cada vez más una figura de poder, se erguía como una autoridad en la materia y era reconocido más allá de lo local. Al mismo tiempo, quien empezaba el recorrido por la erudición -generalmente, personas muy jóvenes- estaba relegado a planos secundarios en el ámbito, pero su objetivo era -y todavía lo es- escalar posiciones y conseguir el prestigio del que gozaban los grandes expertos. Entre las 
fuentes consultadas se distinguen tres tipos de erudición vigentes también en la actualidad: la del melómano erudito, el programador y el coleccionista respectivamente.

- El melómano erudito. Éste es una persona bastante curiosa por la música que escucha y se documenta todo lo posible sobre el repertorio que va abordando. Normalmente no sobrepasa los 40 o 45 años. Valga decir que en los eventos de melómanos y coleccionistas encontré jóvenes que no superaban los 28 años y que, durante la época del boom bogotano, melómanos como Jenny Pérez y Charly Valencia, hoy expertos, habían iniciado su camino hacia la erudición en la adolescencia, cuando aún eran escolares. La erudición de este tipo de melómano abarca ante todo lo referente al sello disquero Fania. Da cuenta, por ejemplo, de la producción de Willie Colón, El Gran Combo de Puerto Rico o Rubén Blades. Está descubriendo el punto cubano y el canto jíbaro portorriqueño y empieza a escuchar más temas de jazz o de latin-jazz. Auditivamente, está muy alerta a la definición del sonido; por ejemplo, si una trompeta ejecuta bien cada nota, si una flauta se oye o se pierde en el conjunto o si cierta voz es la de Graciela Grillo o la de Olga Guillot; es decir, identifica algunos timbres de intérpretes connotados en la historia pero no tan comerciales. Sin embargo, este ejercicio lo realiza oyendo vinilos al tiempo que discos compactos, la radio o la Internet; característica que lo diferencia del programador o coleccionista, que en público o en privado únicamente escucha discos de acetato.

Este melómano escucha también otros estilos salseros; no controvierte la escucha de la salsa balada o el merengue romántico dominicano. ${ }^{215}$ Pese a no figurar en el estrado de los concursantes en los eventos de coleccionismo o encuentros especializados de determinados géneros salseros, asiste a tantos eventos de escucha como le sea posible. Las prácticas mencionadas le han supuesto cierto entrenamiento auditivo y algunos referentes de crítica que lo ayudan a cimentar su gusto musical y a establecer comunicación con expertos de otro nivel.

\footnotetext{
${ }^{215}$ Normalmente, estos jóvenes oyentes escuchan todo tipo de salsa; hay quienes incluso oyen reggaetón. No obstante, entre los colaboradores de esta tesis se presentaron algunas excepciones, o sea, jóvenes seguidores de la salsa que no se adhieren a estos nuevos estilos.
} 
- El programador o Dj. El saber adquirido por algunos melómanos orbitó más allá de una realización personal y se vehiculó hacia los lugares de la rumba. El éxito de las discotecas estribó indefectiblemente en la idoneidad del programador que estuviera a cargo. Éste ostentaba dos tipos de conocimiento fundamentales para su actividad: el de la emocionalidad de los públicos en la medida en que iba evolucionando la rumba y el conocimiento en profundidad de las producciones musicales. No obstante, la programación en las discotecas o salsotecas de finales de los setenta y durante la década de los ochenta exhibe contundentes diferencias con la actual. Actualmente el Dj no tiene la oportunidad de realizar comentarios entre pieza y pieza; durante esa época las canciones se presentaban con una reseña breve que contextualizaba el tema, el género musical o al intérprete. Era imperativo que en unas cuantas frases se proporcionara la información precisa para instruir al rumbero con datos muy interesantes o curiosos que acapararan su interés. A través de esa práctica el programador propiciaba la formación y ampliación del gusto musical de sus audiencias, lo cual redundaba en la promoción cultural de la salsa y en el incremento del repertorio para programar la nutrida agenda de las salsotecas bogotanas. Hay que recordar que los asistentes iniciaban la rumba cada vez más temprano. Al principio comenzaban los jueves, luego añadieron los miércoles y así, sucesivamente, hasta que alcanzaron los siete días de la semana.

En cuanto al despliegue emocional del público durante el transcurso de la sesión, el Dj debía captar inmediatamente los cambios en la motivación de la concurrencia. El indicador de que el ambiente emocional era el adecuado se medía en términos de la cantidad de personas o parejas que no acudían a la pista de baile. El objetivo principal del Dj era mantener a los bailadores activos durante toda la «jornada», de manera que si decaía la actividad debía saber rápidamente que tema devolvería el entusiasmo a la escena. Naturalmente los bailadores se cansaban, lo que suponía que, de cuando en cuando, el Dj alternara las piezas que transmitía con otras más tranquilas o cadenciosas. Aprovechaba entonces estos lapsos para introducir una guajira, un bolero o una cumbia y, a la vez, incrementar el bagaje del oyente. Con este conocimiento tan sensible a la emocionalidad colectiva y el manejo que 
poseía en cuanto al repertorio, el programador otorgaba identidad al lugar y se establecía, asimismo, como autoridad en la materia. La profesión de Dj adquirió estatus en el ámbito salsero bogotano; no cualquiera podía ejercerla, motivo por el cual el programador comenzó a ser una figura profesional, connotada y respetada en el círculo salsero de la ciudad.

- El coleccionista. La fijación del coleccionista con el vinilo es tan obstinada como el conocimiento que precede a cada uno de los discos que atesora. Aunque para ciertas personas la actividad se ha convertido en algo un poco solitario, se evidencia que una faceta importante de la interacción coleccionista yace en la presentación pública. Los eventos de coleccionismo permiten identificar la profundidad de conocimiento que alcanza cada participante sobre un tema, un compositor, un instrumentista o un cantante y permiten saber qué música posee el otro. A su vez, el coleccionismo estimula la búsqueda de sellos discográficos o artistas desconocidos, mientras favorece una muy pequeña y exclusiva -pero fuertemente afincada- cadena de comercio de discos de acetato. Tradicionalmente, las redes comerciales de vinilos de salsa y música cubana son gestionadas por antiguos melómanos expertos que saben sobre las preferencias de sus clientes y conocen cada entresijo del negocio. Por añadidura, la presentación pública ha originado que se ensalce la imagen del coleccionista y ha procurado el elogio de diversas personalidades que se han convertido en figuras icónicas y modélicas de este ejercicio en el movimiento salsero local.

Los coleccionistas bogotanos más antiguos, quienes comenzaron la labor y fueron instaurando los eventos, cuentan con un nivel muy alto de erudición salsera. Han desarrollado un olfato agudísimo para rastrear los ancestros musicales (cubanos y portorriqueños especialmente) y llegan a describir con propiedad las raíces europeas o africanas y las cronologías de aparición y evolución de los variados ritmos y aires musicales del Caribe, incluidos los colombianos. En algunos casos, el gran erudito coleccionista ya no es afecto a la buena salsa neoyorquina. No se compromete con valoraciones degradantes hacia el híbrido salsero y, de hecho, reconoce a magníficos instrumentistas, compositores o arreglistas, mas ha decidido inclinarse por los ricos matices de las voces potentes y limpias, las cuerdas impecablemente 
pulsadas o las letras «sin pretensiones» que portan las canciones de antaño. Generalmente, este tipo de erudición va más allá de Nueva York y del Caribe, ya que el coleccionista cultiva el saber por músicas como el tango, el samba, la bossa nova, la cueca chilena, el joropo colombo venezolano, entre tantos diversos géneros musicales de la tradición latinoamericana que salieron a relucir en sus comentarios (durante el transcurso de las entrevistas) e incluso abordan la música clásica occidental.

Conseguir una posición de estatus en el medio coleccionista bogotano es una cuestión compleja ya que, en palabras de los colaboradores de esta investigación, «el gremio es poco abierto». No obstante, entre batallar y batallar, la mujer, que ha coleccionado desde antes y tiene información trascendental acerca del campo, ha encontrado un pequeño sitio en este dominio decididamente masculino. La presencia de una mujer que participe en eventos y hable con propiedad de la música, es cosa rara. Por eso son muy pocas las que gozan de cierto respeto como coleccionistas. Es bastante llamativo que no se hallaran antecedentes femeninos en la escena de la programación de los ochenta, ${ }^{216}$ pero en la actualidad comienzan a emerger coleccionista femeninas, que al mismo tiempo participan de forma bastante activa en la escena local y poco a poco empiezan a visitar otras ciudades. Véanse los casos de Jenny Pérez o Claudia Forero que tienen cierta resonancia en la materia.

\section{La realización emocional y corporal de la libertad y la felicidad en la vida cotidiana.}

Los informantes que colaboraron en el desarrollo de la presente investigación doctoral atestiguan que la salsa influyó categóricamente sobre los procesos sociales de su juventud y que hoy es vital para consolidar significados en la vida diaria. La apropiación de la salsa ha hecho posible la generación de mundos de sentido en los

\footnotetext{
${ }^{216}$ No he encontrado referencias a coleccionistas femeninas del boom salsero bogotano en la breve literatura que existe sobre la salsa en Colombia ni en el grupo de mis informantes. A excepción del periodo comprendido entre finales del siglo pasado y el momento actual, ninguna mujer participó en calidad de concursante en los encuentros de coleccionismo y mucho menos como Dj. Sobre este particular consigno en el epígrafe 2.5 el testimonio de la coleccionista y estudiosa de este fenómeno, Claudia Forero.
} 
públicos bogotanos, mundos de sentido que se encuentran determinados, en mayor medida, por los siguientes factores:

1. La salsa convertida en el género de la alegría. La salsa ha sido construida categóricamente como el género de la alegría. Cuando los salseros acuden a la música, dicha estabilización de significado anula la percepción negativa que puedan conllevar las conmociones interiores de los sujetos o las adversidades de la realidad. En Colombia tal premisa ha contado con una sedimentación histórica amparada, en primer lugar, en la sonoridad salsera de rítmicas enérgicas y tímbricas estridentes. En segundo lugar, en la forma en que se promovieron las músicas tropicales y caribeñas como músicas festivas en oposición al carácter supuestamente sobrio y melancólico de las músicas andinas. En tercer lugar, en la manera con la cual la industria cultural define en la propaganda el temperamento estimulante y la índole bailable del género. Así, en la salsa se promueve la negación de la adversidad y, en consecuencia, las aflicciones de la vida, lejos de ser elaboradas o ritualizadas en la performance de los oyentes, desaparecen o son invisibilizadas. Por lo tanto, hay una práctica común de pensamiento que porfía en alcanzar un significado emocional y se constituye entonces un mundo de sentido donde es posible la felicidad.

2. La materialización de la libertad. Los jóvenes que vivieron el boom salsero bogotano durante la década de los ochenta inventaron y encontraron caminos para materializar la libertad a través de la música y de las interacciones que ella implicaba. Ya durante años anteriores habían identificado lo subversivo de la salsa y ello alentó la emancipación juvenil ante lo institucional, al tiempo que supuso nuevas definiciones en la escena salsera. En el modelo de libertad que elaboraron los jóvenes en la salsa intervinieron dos factores de capital importancia: la disposición del género musical a experimentarse tan «corporeizadamente» y el disfrute colectivo de la música, con lo cual estos aspectos influyeron decididamente en la imagen corporal y el gesto social de los jóvenes que asistían a la escena de la rumba. La imagen corporal era definida, sobre todo, por el atuendo, el maquillaje y lo comúnmente denominado sabor a la hora de bailar. El gesto social estaba determinado por el comportamiento de los jóvenes en la discoteca y fuera de ella: cómo se acercaba el pretendiente a una potencial pareja de baile, cómo la abordaba, luego (si aceptaba la invitación) qué desempeño tenía la pareja en la pista. Estos elementos eran confeccionados detalladamente por cada actor; es decir, cada cual elaboraba personalmente el mecanismo más efectivo para su 
interacción. Por añadidura, en Bogotá se instauró una nueva ruta para experimentar la música y la escena salsera, porque empezaron a generarse espacios menos convencionales de disfrute donde lo acostumbrado pasó a segundo plano: el atuendo del bailador no era un imperativo estético ni social; dentro de la taberna se incentivó el ánimo por escuchar y hablar más que por bailar; los asistentes podían bailar solos; las mujeres iban sin acompañante; acudían universitarios y también personalidades de corte académico, intelectual y de la izquierda; se animaron discusiones sobre la realidad social latinoamericana y sobre el mundo cultural. Esto se percibió como un giro en la funcionalidad de la taberna y alentó el ideal de libertad aun dentro de las prácticas prototípicas de la misma escena.

3. Los encuentros musicales y culturales de la 19. La adquisición de la salsa grabada estableció un marco de circulación y de interacciones que comenzaban en la calle 19 del centro de Bogotá y terminaban en las casas particulares de cada oyente. Recurrir a la 19 era una necesidad y allí el melómano se descubrió sumergido en un universo cultural de amplias y profundas dimensiones. Ello se vio reflejado en los siguientes aspectos:

- Conocimiento de amplio repertorio. Los vendedores de discos de acetato, instalados en las casetas callejeras, hacían resonar en sus equipos de sonido la música que los melómanos estaban buscando o que ellos pretendían vender. Los clientes escuchaban lo que requerían, pero inevitablemente oían también producciones de distinta índole de los clientes de otras casetas contiguas. En consecuencia, las afinidades por ciertos intérpretes o agrupaciones, o por ciertas sonoridades salseras, promovieron la asociación entre oyentes desconocidos que compartían los mismos gustos por la salsa u otras músicas caribeñas.

- Muchas personas preferían una lista personalizada del repertorio, por lo cual encargaban a los comerciantes la grabación de sus listas en casetes. Esta clase de copiado se elaboraba en ocasiones en el hogar a partir de transmisiones radiales, pero la grabación encargada verificaba un corte «más especializado». 
- Cuando se adquiría un acetato importante, que se había deseado durante mucho tiempo, se organizaban sesiones de audición colectiva en casa con los amigos de siempre o con las nuevas amistades forjadas en La 19.

4. La relación personal con el sonido en la privacidad de la casa. Posteriormente, la privacidad de la casa impulsa una relación más personal del oyente con la salsa. Lejos del bullicio de la 19 y de la misma rumba nocturna, los salseros afinan su audición para encontrarse de manera más íntima con las voces de los cantantes, desentrañar las historias que narran las canciones y permitir que los sonidos articulados en los textos esbocen los universos caribeños que promete el son cubano o las vorágines urbanas que consagra la salsa neoyorquina. En cierto sentido, el circuito de la 19 a la casa del oyente posibilitó integrar el trópico en Bogotá. La realización del salsero bogotano de los años ochenta como habitante alegórico del Caribe no hubiera sido posible sin la presencia de los intercambios que acaecían en la 19 y que culminaban en la audición privada.

5. La música como territorio. Para los salseros que cultivan la escucha y privilegian el disfrute de la música en casa, la construcción de un territorio en la sonoridad de la salsa o sus antecesores caribeños es vital. Hay dos razones fundamentales para ello: En principio, la necesidad de autorregularse emocionalmente y, después, el empeño por mantener y defender un espacio que sea identificado como propio por el otro, por el extraño. Es decir, para construir lugares de pertenencia y diferencia en un entorno habitado por vecinos o transeúntes que puedan amenazar con sus ruidos la tranquilidad del oyente. La conexión espacio-sonido es esencial para la apropiación del territorio. Describo los dos casos mencionados:

- Para mis entrevistados, personas con intensas jornadas laborales, o con más de un trabajo, es indispensable comenzar o terminar el día con una cuota de música que los disponga anímica y corporalmente para iniciar la faena o, si es durante la tarde, para empezar las horas de descanso. El hábito del café mañanero, por ejemplo, incluye la cocina y melódicas cuerdas al compás de punto cubano, o el salón y robustos trombones de salsa neoyorquina. En cada persona es diferente la elección de los géneros salseros: para algunos la salsa debe constituir un estimulante energético mientras que para otros debe implicar desconexión y relajación. 
- La capital es una ciudad con un elevado grado de contaminación auditiva. Incluso los salseros que residen lejos del centro de la ciudad o los que viven o han vivido en ciudades europeas, atestiguan que el ruido de los otros ha llegado a invadir -en ocasiones violentamente- la privacidad de la casa. El ruido puede comprender desde las conversaciones cotidianas de los vecinos, incluidos sus gritos, sus carcajadas y «su música», hasta el alboroto callejero y el estrépito de las autopistas. Cuando la irrupción es inevitable, adecuar o provisionar el entorno sonoro con salsa, es requisito para habitar el lugar.

\section{Performatividad y producción de subjetividad.}

El acto performativo en la música señala la capacidad de generar realidad y de controlarla. Rotundas evidencias de ello son las vivencias del oyente promedio, que quizás no sea el más instruido en materia de historia y disciplina de la salsa, pero que ajusta en el ejercicio de la escucha una emocionalidad y un ambiente propicios para configurar subjetividades. La performance permite construir un yo deseado e imaginado porque en su operatoria el cuerpo salsero asume la forma, el gesto, la actitud, para ser quien necesita ser; de esto se infiere que el acto performativo es estratégicamente identitario. Entre las vivencias de la salsa que se expusieron a lo largo de esta tesis, se observan experiencias performativas afectadas por lo privado y por lo público. La performance privada, en la intimidad de la escucha, y la pública, en la colectividad de la rumba o en otros espacios urbanos, verifican dos clases de experiencia que establecen la realización del yo deseado y la representación del otro.

1. El yo deseado. En la performance salsera el oyente puede incorporarse en el yo que ha soñado ser. La realización de ese yo anhelado se produce en tres espacios diferentes:

- el lugar preferido de la casa, donde normalmente el oyente disfruta la música a solas y, de vez en cuando, acompañado;

- la discoteca, lugar socialmente establecido, en el que se encuentran muchas personas allegadas y desconocidas; 
- los espacios de trabajo y los espacios urbanos, en los cuales la performance estipula obligatoriamente al otro.

En estos contextos locativos la performance orienta las siguientes elaboraciones del yo:

- Performance salsera en la privacidad de la casa. El melómano que disfruta en la comodidad de su sala, su oficina doméstica o -como se vio en capítulos anteriores- su terraza, ama la fantasía que le proporciona el mecanismo performativo. Organiza sus sesiones de escucha disponiendo los grupos y los discos que va a oír, algunas veces, con el único objeto de disfrutar de un concierto personalizado y, otras, compartiendo la escucha con alguna actividad hogareña. El hecho de estar en cierta forma apartado de los demás le permite visualizar e imaginar aquello que lo hace sentir protagonista de un ambiente imaginado o en un espacio real que conoció hace mucho tiempo y que ahora quiere recrear. Por lo tanto, canta y baila mientras pasea por un malecón de La Habana, o es el mejor bailador de la discoteca a la cual acudió alguna vez en su juventud. En la intimidad, en el confort de su casa, la performance del salsero se acopla a sus fantasías y permite la elaboración de las mismas, con lo cual otorga valor y sentido a los momentos de escucha.

- El cuerpo liberado. En los sitios de rumba la potencia de las rítmicas o de las mixturas tímbricas de la salsa invoca, sustancialmente, el movimiento. La percusión acelerada de las congas de un guaguancó, los metales disonantes y estridentes de Willie Colón, el piano arrebatado del «Jala jala» o cualquier otro llamado inicial de una pieza salsera, intervienen de inmediato en el cuerpo. «Antes» y «en» la pista de baile hacen que la hexis corporal varíe. Enseguida, en la plenitud del sonido, el bailador se abandona absolutamente al gesto y al movimiento. En los pasos del baile salsero, que no se ciñen a una secuencia coreografiada, el cuerpo se despliega a sus anchas. En cada pieza de baile salsero, a diferencia de otros estilos quizás más mesurados, el cuerpo actualiza su postura borrando trazos de anteriores trayectorias. Es un cuerpo que en el transcurso del baile deviene nuevo y liberado, que sabe que domina la escena y que, ante la mirada del otro, está fluyendo sin ataduras. 
En la discoteca, ante sus propios ojos, los de su pareja y los de los demás, el bailador es el cuerpo que siempre ha deseado ser.

Sin embargo, se observó que en esa liberación hay un efecto más expansivo para la mujer. ¿En qué sentido? Primero, porque la nueva taberna que se gesta «a lo intelectual» ofrece la posibilidad de romper los convencionalismos rumberos, como se ha comentado antes. Los gestos de llegar o estar en la taberna sin acompañante, bailar sola, elaborar pasos a su albedrío, bailar entre mujeres o en grupos de mujeres, sacar -ella- a bailar a un hombre, son indicadores de empoderamiento que influyen en su performatividad a la vez que anuncian una disrupción de los modelos patriarcales. Después, porque en el momento del boom rumbero la mujer no participaba ni de la programación ni de los eventos de coleccionismo, aunque sí coleccionara. Por consiguiente, los sitios de rumba le daban más oportunidades reivindicatorias en aquellos espacios de rebelión que permitía la salsa.

Esta clase de liberación a través del sonido salsero, además de poder producirse en la discoteca, puede tener lugar también en otros espacios. En el recorrido de campo de esta tesis tuvieron lugar algunos encuentros casuales que pusieron en evidencia la liberación corporal. El caso de Jairo Villaruel en la tienda de vinilos de Jacobo Vargas demuestra la capacidad performativa de la salsa, su capacidad exorbitante a la hora de actuar en el cuerpo salsero. Allí, el cuerpo adquiere la legitimidad que posiblemente no tiene en otras situaciones, porque la imagen «naturalizada» que se ha construido en el consenso social se diluye en el cuerpo empoderado que se gestiona en la estesis sonora del baile; aspecto que comprueba una de las realizaciones más fehacientes de la libertad individual y social en las interacciones con el género salsero.

- El cuerpo de poder. Para algunos salseros la manera de ser estridente y vertiginosa de la salsa les dota de una herramienta para irrumpir enérgicamente en los espacios o para trastocar o quebrantar un ambiente. En los sitios en que transcurre la vida urbana está dispuesto un «orden» que en 
cierto momento puede alterar la tranquilidad o el bienestar. En compensación, se utiliza la música con el fin de proveerse del poder de adecuar las sensaciones, emociones y gestos precisos para neutralizar una situación agresiva, para encontrar la calma o para procurar calidez a un lugar o instante determinado. Tales usos son predominantes en espacios como el trabajo o en sitios de movilidad urbana. Los entrevistados que identifican u otorgan este poder a la salsa reconocen que es imperativo dislocar la monotonía de la oficina o el estrés producido por las rutinas cotidianas, que en determinados momentos pueden poner en peligro la calma de las personas. Por medio de sus artefactos tecnológicos o a través la re-creación y reproducción corporal de la música, ellos eligen los temas que acomodan la situación a su conveniencia. Para algunos melómanos, dislocar las estructuras de lo establecido a través de la salsa es una suerte de actitud o reacción obligatoria para sobrellevar las cargas de la cotidianidad. De cierta manera, esa auto-regulación emocional en entornos que no pueden controlar a cabalidad, que son controlados por otros o por la institucionalidad del medio, les provee de poder, les permite sentir que gobiernan la situación. Asimismo ocurre en los a menudo pesados recorridos peatonales o en el transporte público de la ciudad. En ellos la incomodidad, la intranquilidad o la agresividad son la norma. El melómano se instala en la sonoridad de la salsa para oponer resistencia. Ya sea que lo note o no el extraño que va a su lado, ejercer esa resistencia impide que aquello establecido para molestarlo consiga su cometido. Entonces, el melómano tiene el poder de organizar el flujo caótico en el que se ve sumergido en los trayectos del trabajo a la casa y viceversa e incluso en otro tipo de espacios públicos.

2. La representación del otro en la construcción del yo. En esta clase de experiencia performativa los melómanos entrevistados lograron articular una actitud personal, afectiva y corporal específica a través de las canciones de la salsa y sus intérpretes. Como si de una traslación simbólica del yo se tratara, se observaron dos formas de construcción identitaria por medio de las identificaciones que los melómanos generan con los personajes de las canciones o lo artistas que los interpretan. En la primera, el oyente se siente totalmente representado en los personajes de las letras. En la segunda, adopta momentáneamente rasgos conocidos 
de la personalidad de los cantantes. Ciertas canciones narran sucesos que ilustran muy cercanamente la realidad vivida, ya sea afortunada o adversa. En ocasiones, el personaje y el hecho descrito eran tan familiares que el melómano encarnaba el personaje y la historia que se contaba. Por esta razón, hizo del tema un emblema personal que lo identificaba y que describía ese hecho o periodo de su vida. En otro tipo de articulación, el melómano identificaba en la biografía, la imagen o la voz del cantante, ciertos rasgos de personalidad que no podría asumir en la realidad. En consecuencia, cuando escuchaba a determinado artista se desvelaba lo malévolo, lo sórdido o lo arrabalero y, en conclusión, podía incorporar por sí mismo tales características.

Con las experiencias relatadas se puede afirmar que la performance salsera asiste a la producción de subjetividades. En este último tipo de performance, el oyente se encarna en un «otro» que narra acertadamente su condición, su emoción, su deseo. El oyente se convierte en ese otro narrado y este fenómeno resulta efectivo cuando en la experiencia estética se articulan componentes de diversa naturaleza: los que competen al género musical y los que pertenecen a la trama que se está desenvolviendo en el oyente. Así, se detectaron interpelaciones relacionadas con las biografías de los intérpretes, los personajes de las canciones, la elaboración lírica de los textos y las vocalidades. El grado de identificación con estos componentes varía en cada melómano; por lo tanto, se observa que si una de estas características es definitiva para uno, para otro no lo es, e incluso puede pasar desapercibida. Por consiguiente:

- En las biografías se reconoce la similitud entre la vida del artista y la del habitante del barrio, cuyos sinsabores pueden ser los de cualquiera; entonces, esa familiaridad denota el origen común del cantante y de su oyente. Pese a ser un ídolo mitificado, es un ser humano y su realidad resuena con la de la comunidad que representa.

- Los personajes de las canciones son una fotografía de los diversos tipos de habitante que tiene el barrio; motivo por el cual en las letras se localizan figuras emblemáticas de la sociedad: desde el estudiante o trabajador que sufre una decepción hasta el delincuente que deambula en las calles o purga una condena en la cárcel (a menudo las elaboraciones líricas permiten 
entrever el resorte moral de sus personajes). De esta forma, el salsero se reconoce a sí mismo en los personajes de las canciones o reconoce al otro en ellos.

- Las letras tienen como fuente la oralidad callejera del barrio latinoamericano, mas están elaboradas en cierto tipo de registro lírico que expresa de una manera muy asertiva, al tiempo que poética, lo que el oyente quiere decir. Por estas razones, los melómanos acuden a ellas, en tanto enuncian lo que el lenguaje cotidiano no sabe comunicar.

- Entre mis entrevistados constaté que muchos no se habían preguntado acerca de la vocalidad de sus intérpretes preferidos, expresamente, sobre las características de las voces que más los interpelaban. Al interrogarles al respecto, llegaron a interesantes conclusiones en el intento de escudriñar aquello que portan las voces. Algunos advirtieron la contundencia de la vocalidad a la hora de experimentar la música, pues la voz llega a desvelar aspectos de la construcción social del cuerpo, al ser un constituyente corporal, ${ }^{217}$ y porque ella revela algo de la trayectoria de los sujetos. Ciertos matices en la voz de los cantantes, como la nostalgia, la sensualidad, la insolencia, la osadía o el tono callejero del barrio, se vinculan en la experiencia musical de los escuchas y, en consecuencia, devienen en asignaciones simbólicas o reales que influyen en la performance. Por otra parte, si bien he tratado la vocalidad como una interpelación potente que alberga la realización performativa de la identidad social del intérprete y la articula con lo que representa para el oyente, en mis informantes se revela, además, que detrás de las vocalidades salseras hay una dimensión reivindicatoria del «ser latino».

Al observar en retrospectiva su función en la música, podría decirse que las voces de la salsa reivindicaron lo latino en términos de unas identificaciones profundas con la vivencia popular en el barrio latinoamericano. En este

\footnotetext{
${ }^{217}$ A partir de la premisa de que la voz es un constituyente de la corporeidad de los sujetos y que, en consecuencia, denota también la trayectoria de un cuerpo, esta tesis contribuyó al desarrollo del concepto de vocalidad. Para ello, se sustentó en los interesantes análisis realizados por Roland Barthes ([1982] 1986) en su texto «El grano de la voz» y por Paula Vilas (2005) en su investigación «A voz dos quilombos: na senda das vocalidades afro-brasileras».
} 
punto es necesario aclarar que hay una construcción de «lo latino» más «pancaribeña» y otra de «lo latino» más «latinoamericana», asunto expuesto en el apartado sobre «La salsa como marco histórico-cultural». Entonces, hay una construcción latinoamericana que tiende a centrarse en el sur del continente y abarca las músicas interpretadas por Inti Illimani, Mercedes Sosa o Violeta Parra, por citar sucintamente. Según mis fuentes, la identificación con lo latino que verifica la salsa se cifra principalmente en una identificación con lo latino pan-caribeño. Sin embargo, en el pensamiento del experto, del erudito salsero que conoce con mayor extensión las músicas del continente, llega a advertirse que lo latino se asume más como lo «latino latinoamericano». Así, la concepción de lo latino pan-caribeño se evidencia más en el bailador, en el que disfruta de la rumba. Superada esta posible confusión, que se trató también en capítulos anteriores, corresponde afirmar que la vocalidad cuenta con una carga de información sustantiva para entender trayectorias y procesos culturales en marcos históricos determinados.

Existen aspectos que deben profundizarse con el ánimo de obtener más respuestas sobre las interpelaciones de la salsa. Por ejemplo, el rol que cumple en la performance del oyente la improvisación, tanto del intérprete (soneo o pregón -característica por excelencia de la salsa viejaguardera-) como del instrumentista (descargas -percusión- y moñas -vientos-metales-). Sin embargo, los niveles de vinculación entre el melómano y la improvisación pueden depender de que ésta sea la registrada en formatos grabados, o bien la que se haga en vivo. También hay que contemplar que este último tipo -en vivoha ido disminuyendo considerablemente durante los últimos tiempos, sobre todo en el canto. Los soneros responden a la tradición salsera de la vieja guardia y, por lo tanto, no se verifican muchos en la actualidad. La importancia del pregón se extingue en aquella salsa, mientras que en la moderna, no llega a ser considerable. No obstante, es necesario plantear una metodología de estudio para el tema en tanto los públicos salseros encuentran estrechos lazos emocionales con el soneo de sus intérpretes y con las improvisaciones instrumentales.

Ahora, comprender a través de las narrativas la experiencia musical, ha supuesto ciertas dificultades. Puesto que la reconstrucción lingüística no es apremiante para el oyente, se presentan cuestiones de consideración: una está relacionada con la falta de conceptos 
estables para describir aquello que sucede con el cuerpo en la estesis sonora. La otra consiste en el uso de frases y términos convencionales o propios del argot salsero, que subsanan cualquier intento de descripción. Por ejemplo: tumbao, sabor, gozar, sucio, melodía, instrumentación, o frases cliché como: la salsa es alegría. Cada vocablo puede representar muchas cosas y sería susceptible de constituir un universo de significación. Lo que sucede en el proceso de estesis es lo más difícil de conceptualizar, porque la comprensión que de ello tiene el oyente es principalmente corporal, pre-lingüística y pre-lógica. Al ser interrogados sobre «eso» que la música «hace» en su cuerpo, la mayoría de mis informantes sencillamente «se movían», como si los ritmos de la salsa transcurrieran tácitamente en sus cuerpos y entonces ellos pudieran explicar con movimiento aquello que se les pedía verbalizar.

Lo planteado en la presente tesis doctoral permite evidenciar que la apropiación de la salsa en Colombia contribuyó a que un país tan disímil en sus dimensiones geográficas y culturales (el territorio está conformado por la costa pacífica, la costa atlántica, la zona andina y la zona amazónica) y con las desmesuradas distancias interpuestas entre sus regiones (debido tanto a las singularidades geográficas como a conflictos históricos, políticos y económicos) lograra, en cierta medida, comprender que era también un país del Caribe. En el segundo capítulo de esta tesis manifestaba que la pretendida construcción de la identidad nacional a través de la música se regía principalmente desde la capital, localizada en el centro del país; por lo cual, las zonas periféricas, si bien eran consideradas integrantes del territorio, no contaban con la aprobación para representarlo. Ahora, como se ha expuesto a lo largo de esta investigación, resulta evidente que no en todas las regiones la salsa fue acogida de la misma manera ya que, en efecto, los habitantes capitalinos encontraron otros sentidos y otras formas de realización en las interacciones que conllevaba la experiencia de la música.

Configurar un mundo de sentido implica tener la posibilidad de articular la realidad de tal forma que sea susceptible de asumirse y explicarse -no necesariamente con medios lingüísticos- por el sujeto mismo. En el recorrido de esta tesis se constató que el melómano salsero bogotano ha conseguido definir prácticas significativas en torno al género musical que superan el aludido desfogue emocional y corporal en el baile. Esta concepción fue forjada en el convencionalismo con que la salsa se presenta al público: su atribuida -no siempre con justedad- alegría al ser heredera de las músicas caribeñas. Sin embargo, hubo una resignificación también del cometido del baile en la década del 
ochenta y posteriormente se desarrollaron otras experiencias corporales con el sonido salsero, cuyo sentido se encuentra intensamente vinculado a los lugares que el melómano tiene que frecuentar fuera de casa: el trabajo, las calles de la ciudad u otros espacios públicos. Es decir, se han consolidado actitudes corporales originadas en la salsa con funciones específicas en la vida cotidiana.

A su vez, el oyente capitalino supo descifrar la riqueza histórica y musical que alberga la salsa, de profundas conexiones con músicas afro-caribeñas y norteamericanas. Entre las estrategias que diseñó para alcanzar ese conocimiento, empezaron a contar imprevisibles ejercicios de socialización y colectividad: programación, comercio, coleccionismo, encuentros o escuchatas, por mencionar algunos. Dichas actividades redituaron paulatinamente en efectos sociales dentro del ámbito salsero, el cual comenzó a erigir una especie de organización con jerarquías establecidas. Cuanto más amplio sea el bagaje sobre la cultura musical del melómano, mayor posición obtendrá éste, y por lo tanto, aumentarán su prestigio y reconocimiento. Tales tendencias sociales tienen como consecuencia el establecimiento de nuevos escenarios de sentido y significado $^{218}$ y en ellos la identidad y la subjetividad encuentran distintas formas de producirse, manifestarse y mostrarse en el intrincado sistema de relaciones de la metrópoli bogotana.

\footnotetext{
${ }^{218}$ A lo largo del trabajo de campo de esta investigación pude registrar que a las dinámicas del movimiento salsero de Bogotá han comenzado a adherirse nuevos melómanos, tanto a los ejercicios de coleccionismo y programación como a las labores comerciales que suscitan alrededor de la salsa. Pero dentro de estas tendencias, presenta mucho interés que algunas personas participen de ciertas actividades, no por el gusto hacia el género musical, sino porque han encontrado actividades que les proveen de réditos económicos. Entre éstas, el negocio de discos de acetato a través de la Internet (de bastante acogida en la presente década por coleccionistas de otros países). Los japoneses, por ejemplo, acreditan una importante dinámica en la adquisición de vinilos. En este sentido, las interacciones que empiezan a gestar tradición, y que he tratado en el desarrollo de esta tesis, en adición a las nuevas, alientan un renacimiento de la escucha de la salsa viejaguardera en generaciones más jóvenes, promueven el comercio de discos de acetato coleccionables y cimentan la tradición salsera de la ciudad.
} 


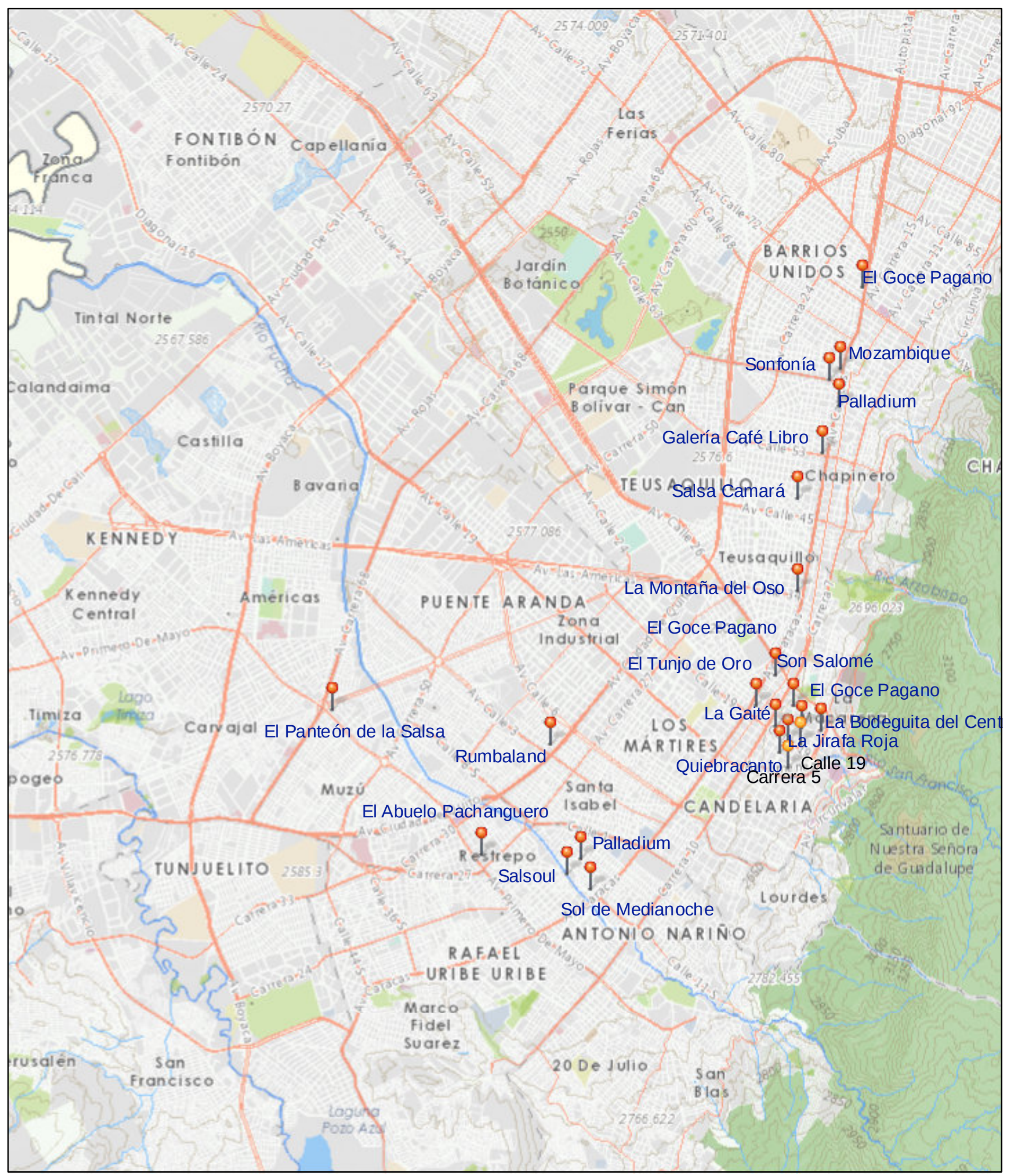

\section{Circuito Salsero Bogotá}

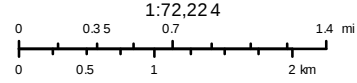

Punto Geodesico

Sitio de Interes

Unidad de Planeamiento
Arbolado Urbano

$25,003563-32,263926$

$32,280363-50,000000$ 


\section{Discografía tratada en la investigación}

\begin{tabular}{|c|c|c|c|c|}
\hline Álbum & $\mathbf{N}^{0}$ Cat $^{*}$ & Año & Tema / Enlace & Intérprete \\
\hline $\begin{array}{l}\text { Esto sí es lo } \\
\text { mío }\end{array}$ & JMTS 1428 & 1978 & $\begin{array}{l}\text { Las caras lindas de mi gente negra } \\
\text { https://www.youtube.com/watch?v=K8yIqo } \\
\text { Q1LpI }\end{array}$ & Ismael Rivera \\
\hline El juicio & SLP 00424 & 1972 & $\begin{array}{l}\text { Aguanile } \\
\text { https://www.youtube.com/watch?v=9IVaSa0 } \\
\text { yKOQ }\end{array}$ & Héctor Lavoe \\
\hline $\begin{array}{l}\text { Puerto Rico } \\
\text { soy tuyo }\end{array}$ & $\begin{array}{l}\text { (61) } 1303 \\
\text { Colombia }\end{array}$ & 1993 & $\begin{array}{l}\text { Tú me vuelves loco } \\
\text { https://www.youtube.com/watch?v=X9fi61r } \\
\underline{\text { TuY8 }}\end{array}$ & Frankie Ruiz \\
\hline Tú y yo & SLP 1125 & 1965 & $\begin{array}{l}\text { Guajira } \\
\text { https://www.youtube.com/watch?v=zpgg_n3 } \\
\underline{\text { 9ZOc }}\end{array}$ & La Lupe \\
\hline $\begin{array}{l}\text { Watermelon } \\
\text { Man }\end{array}$ & BM 6120 & 1963 & $\begin{array}{l}\text { Watermelon man } \\
\text { https://www.youtube.com/watch?v=CSOOO } \\
\underline{\text { AaS8eY }}\end{array}$ & $\begin{array}{l}\text { Mongo Santamaria } \\
\text { And His Orchestra / } \\
\text { La Lupe }\end{array}$ \\
\hline $\begin{array}{l}\text { De ti } \\
\text { depende }\end{array}$ & JM 00492 & 1976 & $\begin{array}{l}\text { Consejo de Oro } \\
\underline{\text { https://www.youtube.com/watch?v=KhOAg }} \\
\underline{\text { VOvhUA }} \\
\text { Periódico de Ayer } \\
\underline{\text { https://www.youtube.com/watch?v=ypYXHo }} \\
\underline{\text { qck_w }}\end{array}$ & Héctor Lavoe \\
\hline Lo mato & SLP 00444 & 1973 & $\begin{array}{l}\text { El día de mi suerte } \\
\text { https://www.youtube.com/watch?v=qZK2wC } \\
\text { pvwZg }\end{array}$ & Héctor Lavoe \\
\hline Siembra & JM-00537 & 1978 & $\begin{array}{l}\text { Pedro Navaja } \\
\text { https://www.youtube.com/watch?v=Fhs7yO4 } \\
\underline{\text { tbY4 }}\end{array}$ & Rubén Blades \\
\hline Vigilante & JM 610 & 1983 & $\begin{array}{l}\text { Juanito Alimaña } \\
\text { https://www.youtube.com/watch?v=iSHZQ } \\
\text { MuwUYY }\end{array}$ & Héctor Lavoe \\
\hline Soy feliz & XVS-35 & 1975 & $\begin{array}{l}\text { Las tumbas } \\
\text { https://www.youtube.com/watch?v=LbN2az } \\
\underline{\text { LxRYE\&list=RDt9gsjztx3f8 }}\end{array}$ & Ismael Rivera \\
\hline El grande & $\begin{array}{l}201011 \\
\text { Colombia } \\
\text { MFS-3292 } \\
\text { E.U. }\end{array}$ & 1975 & $\begin{array}{l}\text { El Preso } \\
\text { https://www.youtube.com/watch?v=DZ2hW } \\
\text { plmioA }\end{array}$ & $\begin{array}{l}\text { Wilson Manyoma } \\
\text { Fruko y sus tesos }\end{array}$ \\
\hline $\begin{array}{l}\text { Jala jala y } \\
\text { Boogaloo }\end{array}$ & LPA 857 & 1967 & $\begin{array}{l}\text { Richie's jala jala } \\
\text { https://www.youtube.com/watch?v=mRYvmj } \\
\underline{8 \_63 c}\end{array}$ & $\begin{array}{l}\text { Bobby Cruz y } \\
\text { Richie Ray }\end{array}$ \\
\hline Vigilante & JM 610 & 1983 & $\begin{array}{l}\text { Triste y vacía } \\
\text { https://www.youtube.com/watch?v=rRHbB8j } \\
\text { jU8c }\end{array}$ & Héctor Lavoe \\
\hline
\end{tabular}




\begin{tabular}{|l|l|l|l|l|}
\hline Cosa Nuestra & SLP 384 & 1969 & $\begin{array}{l}\text { Ausencia } \\
\text { https://www.youtube.com/watch?v=93xwK9 } \\
\text { YNnC4 }\end{array}$ & Héctor Lavoe \\
\hline
\end{tabular}

* El número de catálogo referido corresponde a la primera edición de cada álbum, normalmente realizada en Estados Unidos. 


\section{Entrevistas y conversaciones}

Las entrevistas y conversaciones llevadas a cabo para la elaboración de esta tesis doctoral fueron realizadas en su mayor parte en la ciudad de Bogotá y algunas en la ciudad de Barcelona durante los años 2014 y 2015. También registro las conversaciones y comunicaciones más relevantes por medios electrónicos. Todas fueron realizadas por la autora.

\begin{tabular}{|c|c|c|}
\hline Persona entrevistada & Actividad & Lugar y fecha \\
\hline Angarita, Laura. & $\begin{array}{l}\text { Profesora de inglés, oyente habitual, } \\
\text { bailadora y asistente a encuentros de } \\
\text { coleccionismo. }\end{array}$ & $\begin{array}{l}\text { Bogotá, } 21 \text { de mayo de } \\
2014\end{array}$ \\
\hline Arteaga, José. & $\begin{array}{l}\text { Comunicador, escritor, experto en } \\
\text { músicas latinas, programador radial. }\end{array}$ & $\begin{array}{l}\text { Diversas comunicaciones } \\
\text { vía mail entre el } 3 \text { de mayo } \\
\text { de } 2014 \text { y el } 27 \text { de } \\
\text { diciembre de } 2016 .\end{array}$ \\
\hline Barreiro, Luz Estela. & $\begin{array}{l}\text { Profesora de danza, nivel escolar. Oyente } \\
\text { habitual. }\end{array}$ & $\begin{array}{l}\text { Bogotá, } 11 \text { de febrero de } \\
2014 .\end{array}$ \\
\hline Benavides Martínez, Gerardo. & $\begin{array}{l}\text { Comunicador y chef, oyente habitual y } \\
\text { bailador. }\end{array}$ & $\begin{array}{l}\text { Barcelona, } 14 \text { de octubre } \\
\text { de } 2014 .\end{array}$ \\
\hline Bernal, Ricardo. & $\begin{array}{l}\text { Abogado, experto en salsa y } \\
\text { coleccionista. }\end{array}$ & $\begin{array}{l}\text { Bogotá, } 30 \text { de enero de } \\
2015\end{array}$ \\
\hline Bernal, Wilson. & $\begin{array}{l}\text { Oyente habitual, comerciante de discos y } \\
\text { organizador de eventos salseros. }\end{array}$ & Bogotá, 5 de junio de 2014 \\
\hline Cantor, Francisco. & $\begin{array}{l}\text { Experto en música cubana, coleccionista, } \\
\text { conferencista. }\end{array}$ & $\begin{array}{l}\text { Bogotá, } 30 \text { de enero y } 8 \text { de } \\
\text { junio de } 2015 .\end{array}$ \\
\hline Carreño, Ismael. & $\begin{array}{l}\text { Experto en salsa y música del Caribe, } \\
\text { programador radial, Dj, coleccionista, } \\
\text { uno de los fundadores de los encuentros } \\
\text { de coleccionismo en la capital. }\end{array}$ & Bogotá, 8 de junio de 2014. \\
\hline Contreras, Alex. & $\begin{array}{l}\text { Músico percusionista de salsa, oyente } \\
\text { habitual. }\end{array}$ & $\begin{array}{l}\text { Bogotá, } 20 \text { de marzo de } \\
2014 .\end{array}$ \\
\hline Córdoba, Wilson. & $\begin{array}{l}\text { Abogado, coleccionista, oyente habitual } \\
\text { y bailador. }\end{array}$ & $\begin{array}{l}\text { Bogotá, } 11 \text { de diciembre de } \\
\text { 2014, } 30 \text { de enero de } 2015 .\end{array}$ \\
\hline Delgado, Daniela. & Abogada, oyente habitual y bailadora. & $\begin{array}{l}\text { Bogotá, } 22 \text { de julio de } \\
2015 .\end{array}$ \\
\hline Díaz Lepiry, Daniel. & $\begin{array}{l}\text { Músico violinista de charanga, director } \\
\text { de La Real Charanga. }\end{array}$ & $\begin{array}{l}\text { Bogotá, } 5 \text { de marzo de } \\
2014 .\end{array}$ \\
\hline Duarte, Óscar Mauricio. & Publicista, coleccionista y bailador. & $\begin{array}{l}\text { Bogotá, } 30 \text { de enero de } \\
2015 .\end{array}$ \\
\hline Forero, Claudia. & $\begin{array}{l}\text { Bibliotecóloga y especialista en Ciencias } \\
\text { de la información, coleccionista, } \\
\text { organizadora de eventos salseros. }\end{array}$ & $\begin{array}{l}\text { Bogotá, } 23 \text { de enero de y } \\
25 \text { de febrero de } 2015\end{array}$ \\
\hline García, Jorge. & Músico guitarrista, oyente habitual. & $\begin{array}{l}\text { Bogotá, } 6 \text { de febrero de } \\
2014 .\end{array}$ \\
\hline
\end{tabular}




\begin{tabular}{|c|c|c|}
\hline García Manrique, Esperanza. & $\begin{array}{l}\text { Administradora del Café Arte y Pasión, } \\
\text { melómana habitual y bailadora. }\end{array}$ & $\begin{array}{l}\text { Bogotá, } 13 \text { de junio de } \\
2015 .\end{array}$ \\
\hline Gómez, Hernando. & $\begin{array}{l}\text { Gerente de su local de discos de } \\
\text { colección. Experto en música del Caribe, } \\
\text { coleccionista, Dj, }\end{array}$ & $\begin{array}{l}\text { Bogotá, } 13 \text { de agosto de } \\
2015 .\end{array}$ \\
\hline Hernández Buesa, Alejandro & Psicólogo, oyente habitual y bailador. & $\begin{array}{l}\text { Bogotá, } 25 \text { de marzo de } \\
2014 .\end{array}$ \\
\hline Martínez, Iván. & Oyente habitual y programador radial. & $\begin{array}{l}\text { Bogotá, } 17 \text { de octubre de } \\
2014 .\end{array}$ \\
\hline Patiño, Pedro. & $\begin{array}{l}\text { Psicólogo, profesor universitario y } \\
\text { oyente habitual. }\end{array}$ & $\begin{array}{l}\text { Bogotá, } 4 \text { de marzo de } \\
2014 .\end{array}$ \\
\hline Piñeros, María Olga. & $\begin{array}{l}\text { Profesora universitaria experta en canto } \\
\text { lírico y popular. }\end{array}$ & $\begin{array}{l}\text { Bogotá, } 25 \text { de noviembre } \\
\text { de } 2015 .\end{array}$ \\
\hline Ramírez, Víctor. & $\begin{array}{l}\text { Músico, arreglista y profesor. Oyente } \\
\text { habitual. }\end{array}$ & $\begin{array}{l}\text { Bogotá, } 29 \text { de septiembre } \\
\text { de } 2014 .\end{array}$ \\
\hline Ramírez, Luz Stella. & $\begin{array}{l}\text { Profesora universitaria, experta en danza, } \\
\text { oyente habitual. }\end{array}$ & $\begin{array}{l}\text { Diversas comunicaciones } \\
\text { entre el } 28 \text { de enero de } \\
2016 \text { y el } 20 \text { de febrero de } \\
2017 .\end{array}$ \\
\hline Rivera Castro, Hilder. & $\begin{array}{l}\text { Gerente de su negocio de maderas, } \\
\text { coleccionista. }\end{array}$ & $\begin{array}{l}\text { Bogotá, } 30 \text { de enero de } \\
2015 .\end{array}$ \\
\hline Romero, Enrique. & $\begin{array}{l}\text { Experto en música latina, programador, } \\
\text { escritor, organizador de eventos. }\end{array}$ & $\begin{array}{l}\text { Barcelona. } 18 \text { de enero de } \\
2014 .\end{array}$ \\
\hline Rodríguez, Alexa.* & $\begin{array}{l}\text { Violonchelista, profesora, oyente } \\
\text { habitual y bailadora. }\end{array}$ & $\begin{array}{l}\text { Bogotá, } 1 \text { de marzo de } \\
2014 .\end{array}$ \\
\hline Rodríguez, Andrés. & $\begin{array}{l}\text { Ingeniero Civil, oyente habitual y } \\
\text { bailador. }\end{array}$ & $\begin{array}{l}\text { Bogotá, } 18 \text { de julio de } \\
2015 .\end{array}$ \\
\hline Rosas Salazar, María.* & $\begin{array}{l}\text { Administrativa universitaria, oyente } \\
\text { habitual y bailadora. }\end{array}$ & $\begin{array}{l}\text { Bogotá, } 16 \text { de marzo de } \\
2014\end{array}$ \\
\hline Sánchez, Enrique «Quike». & $\begin{array}{l}\text { Ingeniero de sistemas, experto en salsa y } \\
\text { música del Caribe, coleccionista. }\end{array}$ & $\begin{array}{l}\text { Bogotá, } 16 \text { de septiembre } \\
\text { de } 2014 \text { y diversas } \\
\text { comunicaciones entre el } 10 \\
\text { de diciembre de } 2015 \text { y el } \\
14 \text { de febrero de } 2016\end{array}$ \\
\hline Valencia Rivas, Charly. & $\begin{array}{l}\text { Gerente de su propio bar salsero, experto } \\
\text { en salsa y música del Caribe, Dj y } \\
\text { bailarín retirado. }\end{array}$ & $\begin{array}{l}\text { Bogotá, } 16 \text { de octubre de } \\
2014 .\end{array}$ \\
\hline Vargas, Jacobo. & $\begin{array}{l}\text { Gerente de su local de discos de } \\
\text { colección. Experto en salsa y música del } \\
\text { Caribe, coleccionista, Dj retirado. }\end{array}$ & $\begin{array}{l}\text { Bogotá, } 22 \text { de enero de } \\
2015 .\end{array}$ \\
\hline Vargas, Will. & $\begin{array}{l}\text { Músico percusionista de salsa, oyente } \\
\text { habitual. }\end{array}$ & $\begin{array}{l}\text { Bogotá, } 30 \text { de abril de } \\
2016 .\end{array}$ \\
\hline Pérez, Jenny. & Abogada, coleccionista, bailadora. & $\begin{array}{l}\text { Bogotá, } 11 \text { de diciembre de } \\
2014 .\end{array}$ \\
\hline
\end{tabular}

* Alexa Rodríguez no autorizó el uso de su nombre real ni permitió un registro grabado de la entrevista, solamente aceptó que tomara notas. María Rosas Salazar no autorizó el uso de su nombre real, pero sí que se hiciera el registro grabado de la conversación. 


\section{BIBLIOGRAFÍA}

Aharonián, Coriún. 1994. «Factores de identidad musical latinoamericana tras cinco siglos de conquista, dominación y mestizaje». Latin American Music Review / Revista de Música Latinoamericana 15 (2): 189-225.

Althusser, Louis. 1970. Ideología y aparatos ideológicos del Estado, Freud y Lacan. Medellín: Pepe.

Anderson, Benedict. 1983. Imagined Communities: Reflections on the Origin and Spread of Nationalism. Londres: Verso.

Arteaga, José. 1988. «Las letras de la Salsa I parte». A Contratiempo 4 (1): 23-24.

. 1989. «La nueva salsa (o el otro Caribe)». Revista A Contratiempo 5 (1): 29-36.

— 1990. La salsa. $2^{\text {a }}$ edición ampliada. Bogotá: Intermedio editores.

1993. «Las ciudades de la noche roja. La cultura de la violencia a través de la

Salsa». En Los imaginarios y la cultura popular, José Eduardo Rueda Enciso, 112-35. Bogotá: Cerec.

—. 2013. «Tromboranga y el sonido del trombón». Salsajazz (Sep): http://www.salsajazz.com/index.php/component/content/article?id=503:trombor anga-y-el-sonido-del-trombon.

Attali, Jacques. (1977) 1995. Ruidos. Ensayo sobre la economía política de la música. Traducido por Ana María Palos. Madrid: Siglo XXI Editores.

—. 2001. «Bruits : essai sur l'économie politique de la musique». Conferencia, Institute of Contemporary Arts. Londres, mayo.

Auslander, Philip. 2006. «Musical Personae». The Drama Review 50 (1): 100-119.

Austin, John. (1962) 1991. Cómo Hacer Cosas con Palabras. Traducido por Génaro R. Carrió y Edaurdo A. Rabossi. Barcelona: Paidós.

Barthes, Roland. (1984) 1987. El susurro del lenguaje. Más allá de la palabra y la escritura. Traducido por C. Fernández Medrano. Barcelona: Paidós Ibérica S. A. (1982) 1986. Lo obvio y lo obtuso: Imágenes, gestos, voces. Traducido por C. Fernández Medrano. Barcelona: Paidós Ibérica S. A.

Béhague, Gerard. 1980. «Improvisation in Latin American Musics». Music Educators Journal 66 (5): 118-125.

Benavides, Ivan. 2014. «Prende la vela, Lucho Bermúdez». Revista Arcadia 100: http://www.revistaarcadia.com/impresa/especial-arcadia-100/articulo/arcadia100-prende-la-vela-lucho-bermudez/35031. 
Bermúdez, Egberto. 2005a. «La música tradicional colombiana y sus estructuras básicas: Música afrocolombiana (Parte 1)». Ensayos. Historia y teoría del arte 10 (1): 215-239.

— 2005b. «Las palabras de la música o la música de las palabras, Segunda Parte». Horas. Tiempo Cultural 19 (1): 22-27.

—. 2010. «La música colombiana, pasado y presente». En A tres bandas: mestizaje, sincretismo e hibridación en el espacio sonoro iberoamericano, 247254. Madrid: Seacex y Akal Ediciones.

Blanco Arboleda, Darío. 2009. «De melancólicos a rumberos... de los Andes a la costa. La identidad colombiana y la música caribeña». Boletín de Antropología Universidad de Antioquia 23/40: 102-128.

Bourdieu, Pierre. (1979) 1998. La distinción: Criterio y bases sociales del gusto. Traducido por María del Carmen Ruiz de Elvira. Madrid: Taurus.

1986. «Notas provisionales sobre la percepción social del cuerpo». En Materiales de sociología crítica. Editado por Fernando Álvarez-Uría y Julia Varela.183-94. Madrid: La Piqueta.

Butler, Judith. (1993) 2002. Cuerpos que importan: sobre los límites materiales y discursivos del «sexo». Traducido por Alcira Bixio. Buenos Aires: Paidós SAICF.

Caicedo, Andrés. 1977. Qué viva la música. Bogotá: Instituto Colombiano de Cultura.

Cámara de Landa, Enrique. 2004. Etnomusicología. $2^{\text {a }}$ Ed. Madrid: Instituto Complutense de Ciencias Musicales.

Cerón, John. 2013. «En la salsa hay mucho payaso: Willie Colón». El Espacio (Ago): http://www.salsaconestilo.com/en-la-salsa-hay-mucho-payaso-willie-colonentrevista/.

Clifford, James. 1997. Routes. Travel and Translation in the Late Twentieth Century. Cambridge: Harvard University Press.

Colón, Willie. 2013. «En la salsa hay mucho payaso, dice el maestro Willie Colón» Entrevista de John Cerón. El Espacio, Bogotá.

Cortés Polanía, Jaime. 2004. La música nacional popular colombiana. En La colección Mundo al día (1924-1938). Bogotá: Universidad Nacional de Colombia: Unibiblos.

Delgado-Ordóñez, Bibiana. 2014. «Una aproximación al análisis intertextual del álbum Beethoven's V». Revista A Contratiempo 23 (1): http://www.musigrafia.org/acontratiempo/?ediciones/revista-

23/artculos/beethovens -v-markolino-dimond-frankie-dante-cotique-1975-unaaproximacin-al-anlisis-intertextual-del.html. 
DeNora, Tia. 2000. Music in Everyday Life. Cambridge University Press.

Dewey, John. (1934) 2008. El arte como experiencia. Traducido por Jordi Claramonte. Barcelona: Ediciones Paidós Ibérica, S. A.

Díaz, José Luis. 2011. «Cronofenomenología: El tiempo subjetivo y el reloj elástico». Salud Mental 34 (4): 379-389.

Eidsheim, Nina. 2009. «Synthesizing Race: Towards an Analysis of the Performativity of Vocal Timbre». Trans. Revista Transcultural de Música13: En línea.

Foucault, Michel. (1979) 1980. Microfísica del poder. $2^{\mathrm{a}}$ ed. Traducido por Julia Varela y Fernando Álvarez-Uría. Madrid: La Piqueta.

(1982) 1990. Tecnologías del yo. Traducido por Mercedes Allendesalazar. Barcelona: Paidós Ibérica.

—. 1988. «El sujeto y el poder». Traducido por Corina de Iturbe. Revista Mexicana de Sociología 50 (3): 3-20.

Frith, Simon. (1996) 2003. «Música e Identidad». En Cuestiones de identidad cultural, editado por Stuart Hall y Paul Du Gay, 181-213. Traducido por Horacio Pons. Buenos Aires: Amorrortu.

- (1987) 2008. «Hacia una estética de la música popular». En Las culturas musicales. Lecturas de etnomusicología, $2^{\text {a }}$ ed., Traducido por Silvia Martínez, editado por Francisco Cruces y otros, 413-35. Madrid: Trotta.

Galeano, Eduardo. 2007. El libro de los abrazos. 26a ed. Madrid: Siglo XXI Editores.

Gallo, Iván. 2014. «La salsa en Bogotá». Revista Las dos orillas: http://www.las2orillas.co/la-salsa-en-bogota/.

García Canclini, Néstor. 1995. Consumidores y ciudadanos. Conflictos multiculturales de la globalización. México: Grijalbo.

Geertz, Clifford. 1973. The Interpretation of Cultures. Nueva York: Basic Books.

Genette, Gérard. (1962) 1989. Palimpsestos. La literatura en segundo grado. Traducido por Celia Fernández Prieto. Madrid: Taurus.

Gómez Serrudo, Nelson Antonio, Jaramillo Marín, Jefferson. 2013. Salsa y cultura popular en Bogotá. Bogotá: Editorial Javeriana.

Gonzáles, Juan Pablo. 2000a. «El canto mediatizado: breve historia de la llegada del cantante a nuestra casa». Revista Musical Chilena 54 (194): 26-40.

Hall, Stuart. 1996. «Quién necesita identidad». En Cuestiones de identidad cultural, editado por Stuart Hall y Paul Du Gay, 13-39. Traducido por Horacio Pons. Buenos Aires: Amorrortu.

—. 2010a. «Significado, representación e ideología: Althusser y los debates postestructuralistas». En Sin garantías. Trayectorias y problemáticas en los 
estudios culturales. Editado por Eduardo Restrepo, Catherine Walsh y Víctor Vich, 193-220. Popayán y varios: Envión Editores y varios.

2010b. «La cuestión de la identidad cultural». En Sin garantías. Trayectorias y problemáticas en los estudios culturales. Editado por Eduardo Restrepo, Catherine Walsh y Víctor Vich, 363-404. opayán y varios: Envión Editores y varios.

Hernández Salgar, Óscar. 2014. «Los mitos de la música nacional. Músicas populares colombianas 1930-1960». Trabajo final de grado. Bogotá: Pontificia Universidad Javeriana.

Ideca. Portal de Mapas de Bogotá. 2017. Alcaldía Mayor de Bogotá. D.C. Unidad Administrativa Especial Catastro Distrital: http://mapas.bogota.gov.co/ portal mapas/\#

Isava, Luis Miguel. 2009. «Breve introducción a los artefactos culturales». Estudios. Revista de Investigaciones Literarias y Culturales 17 (34): 439-452.

Jarman-Ivens, Freya. 2011. Queer Voices. Technologies, Vocalities, and the Musical Flaw. Nueva York: Palgrave Macmillan.

Johnson, Mark. 2007. The Meaning of the Body. Aesthetics of Human Understanding. Chicago: The University of Chicago Press.

López Cano, Rubén. 2007. «Música e intertextualidad». Pauta. Cuadernos de teoría y crítica musical 104: 30-36.

- 2007a. «El chico duro de la Habana. Agresividad, desafío y cinismo en la timba cubana». Latin American Music Review 28 (1): 24-67.

2007b. «Semiótica, semiótica de la música y semiótica cognitivo-enactiva de la música. Notas para un manual de usuario. Texto didáctico.» www.lopezcano.net.

. 2008. «Performatividad y narratividad musical en la construcción social de género. Una aplicación al Tango queer, Timba, Regetón y Sonideros». En Rubén Gómez Muns y Rubén López Cano, eds. Músicas, ciudades, redes: creación musical e interacción social. Salamanca: SIbE-Fundación Caja Duero.

. 2013a. «Música, mente y cuerpo. De la semiótica de la representación a una semiótica de la performatividad» En Marita Fornaro, ed., 41-78. De cerca, de lejos. Miradas actuales de la musicología de/sobre América Latina. Montevideo: Comisión Sectorial de Educación Permanente Universidad de la República. Escuela Universitaria de Música.

Madrid, Alejandro. 2009. «¿Por qué música y estudios de performance? ¿Por qué ahora?: una introducción al dossier». TRANS. Revista Transcultural de Música (13): http://www.sibetrans.com/trans/articulo/2/por-que-musica-y-estudios-deperformance-por-que-ahora-una-introduccion-al-dossier.

Mandoki, Katya. 2006a. Estética cotidiana y juegos de la cultura: Prosaica l. México: Siglo XXI. 
2006b. Practicas estéticas e identidades sociales. Prosaica II. México: Siglo XXI.

Manuel, Peter. 2004. «Improvisación en la música de baile latina: historia y estilo». En En el transcurso de la improvisación. Estudios sobre el mundo de la improvisación musical, editado por Bruno Nettl y Melinda Russell, 125-144. Madrid: Ediciones Akal S. A.

Martí, Josep. 2000. Más allá del arte. La música como generadora de realidades sociales. Sant Cugat del Valles: Deriva.

Martín-Barbero, Jesús. 2003. «Saberes hoy: diseminaciones, competencias y transversalidades». Revista Iberoamericana de educación 32: 17-34.

Mead, George Herbert. (1925) 1991. «La Génesis del self y el control social». Traducido por Ignacio Sánchez de la Yncera Reis 55: 165-186.

Mendívil, Julio. 2013. «The song remains the same? Sobre las biografías sociales y personalizadas de las canciones». El oídio pensante 1 (2):1-27.

Merleau-Ponty, Maurice. (1945). 1993. Fenomenología de la percepción. Traducido por Jem Cabanes. Buenos Aires: Planeta.

Merriam, Alan P. (1977). 2008. «Usos y funciones». En Las culturas musicales. Lecturas de etnomusicología. $2^{\mathrm{a}}$ ed., traducido por Luis Costa, editado por Francisco Cruces y otros, 275-96. Madrid: Trotta.

Middleton, Richard. 1990. Studying Popular Music. Filadelfia: Open University Press.

— 2006. Voicing the Popular: On the Subjects of Popular Music. Nueva York y Londres: Routledge Taylor \& Francis Group.

Morales, Ed. 2003. The Latin Beat: The Rhythms and Roots of Latin Music, from Bossa Nova to Salsa and Beyond. Boston: Da Capo Press.

Navia, José. 2007. «Así se vive el movimiento de la salsa en Bogotá». El tiempo (Ene): http://www.eltiempo.com/archivo/documento/CMS-3389974.

Nettl, Bruno. 2003. «Reflexiones sobre el siglo XX: el estudio de los "Otros" y de nosotros como etnomusicólogos». TRANS. Revista Transcultural de Música 7: http://www.sibetrans.com/trans/articulo/213/reflexiones-sobre-el-siglo-xx-elestudio-de-los-ldquo-otros-rdquo-y-de-nosotros-como-etnomusicologos\#_ftn1.

Pagano, César. 1993. Ismael Rivera: El sonero mayor. Bogotá: Ediciones Antropos. . «Conversación en tiempo de bolero». 1994. Historia del bolero. Bogotá: Javeriana Estéreo: https://www.youtube.com/watch?v=3zOf2ahqqhM.

Palominos Mandiola, Simón, y Juan Pablo González. 2013. «Transformaciones de lo popular en la música: prácticas de escucha, géneros y construcción del gusto a través de los medios de comunicación». En XXIX Congreso Latinoamericano de Sociología, ALAS Chile. Santiago de Chile: Universidad Alberto Hurtado. 
Pelinski, Ramón. 2000. Invitación a la etnomusicología. Quince fragmentos y un tango. Madrid: Ediciones Akal.

—. 2005. «Corporeidad y experiencia musical». TRANS. Revista Transcultural de Música 9: http://www.sibetrans.com/trans/articulo/177/corporeidad-yexperiencia-musical.

Pérez, José, y Antonio Mejías. 1997. La historia del cantante, Héctor Lavoe: 19461993 : una biografía. Nueva York: Lavoe \& Infante.

Ramos, Josean. 1993. Vengo a decirle adiós a los muchachos. San Juan: Sociedad de Autores Libres.

«Real Academia Española». 2014. Diccionario de la lengua española. Madrid.

Rice, Timoty. 2001. «Hacia la remodelación de la etnomusicología». Traducido por Miguel Ángel Berlanga. En Las culturas musicales: lecturas de etnomusicología, Coord. Francisco Cruces Villalobos, 155-78. Madrid: Trotta S. A.

— 2003. «Tiempo, lugar y metáfora en la experiencia musical y en la etnografía». En Los últimos diez años de la investigación musical, Jesús Martín Galán y Carlos Villar-Taboada, coordinadores, 91-126. Valladolid: Universidad de Valladolid.

Ricoeur, Paul. (1985a) 2004. Tiempo y narración I. Configuración del tiempo en el relato histórico. $4^{\mathrm{a}}$ ed. Traducido por Agustín Neira. México: Siglo XXI Editores.

. (1985b) 2009. Tiempo y Narración III. El tiempo narrado. $4^{\mathrm{a}}$ ed. Traducido por Agustín Neira. México: Siglo XXI Editores.

Rodríguez, Nelson. 2001. «"Palabra” and Salsa Romantica». Latin Beat Magazine: https://www.highbeam.com/doc/1G1-79513831.html.

Rondón, César Miguel. (1978) 2007. El libro de la salsa: crónica de la música del Caribe urbano. $3^{\mathrm{a}}$. Caracas: Ediciones B. Venezuela.

Santamaría-Delgado, Carolina. 2014. Vitrolas, rocolas y radioteatros. Hábitos de escucha de la música popular en Medellín, 1930-1950. Bogotá: Pontificia Universidad Javeriana.

—. 2016. Comunicación personal al autor, febrero 4.

Santana Archbold, Sergio. 1992. ¿Qué es la salsa? Buscando la melodía. Ediciones Salsa y Cultura. Medellín.

Sección Cultura. 2015. «La invaluable colección de César Pagano». Revista Semana: http://www.semana.com/Imprimir/447271.

Sessions, Roger. 1979. Roger Sessions on Music. Collected Essays. Edward T. Cone. New Jersey: Princeton University Press. 
Shapiro, Marc. 2007. Passion and pain. The life of Hector lavoe. Salsa was his legacy, his triumph, and his tragedy. 1st ed. Nueva York: St. Martin’s Griffin.

Shusterman, Richard. 2000. Pragmatis Aesthetics. Living Beauty, Rethinking Art. $2^{\mathrm{a}}$ ed. Lanham: Rowman \& Littlefield Publishers, Inc.

Silva Guzmán, Mauricio. 2004. «Joe Arroyo, el rey no ha muerto». Revista Rollingstone (Mar): http://www.rollingstone.com.ar/584610-joe-arroyoel-rey-no-ha-muerto.

Slobin, Mark. 1993. Subcultural Sounds: Micromusics of the West. Londres: Wesleyan University Press.

Straw, Will. 1991. «Systems of Articulation Logics of Change: Communities and Scenes in Popular Music». Cultural Studies.

Torres, Vicente Francisco. 1998. La novela bolero latinoamericana. 1. ed. El Estudio. México: Coordinación de Difusión Cultural Dirección de Literatura UNAM.

Troyano, Ela. 2007. La Lupe Queen Of Latin Soul. Documental. Editado por Josh Cramer y Brian A. Kates, A. C. E. PBS. 55 min: https://www.youtube.com/watch?v=260NgK-GLig.

Ulloa. 2009. La salsa en discusión. Música popular e historia cultural. Segunda Edición. Cáli: Universidad del Valle.

Valentín Escobar, Wilson A. 2002. «El Hombre Que Respira Debajo Del Agua: TransBoricua Memories, Identities and Nationalisms Performed through the Death of Héctor Lavoe». En Situating Salsa: Global Markets and Local Meanings in Latin Popular Music, editado por Lise Waxer, 161-85. Nueva York y Londres: Routledge.

Valverde, Umberto. 1981. Celia Cruz : Reina Rumba. Bogotá: La Oveja Negra.

—— 1983. Bomba camará. Bogotá: Oveja Negra.

Vila P. 1996. «Identidades narrativas y música. Una primera propuesta para entender sus relaciones». Trans. Revista Transcultural de Música 2. http://www.sibetrans.com/trans/a288/identidades-narrativas-y-musica-unaprimera-propuesta-para-entender-sus-relaciones.

Vilas, Paula Cristina. 2005. «A voz dos quilombos: na senda das vocalidades afrobrasileras». Horizontes Antropológicos 11 (24): 185-197.

Wade, Peter. 2002. Música, raza y nación. Música tropical en Colombia. Traducido por Adolfo Gonzáles Enriquez. Bogotá: Vicepresidencia de la República de Colombia.

Washburne, Christopher. 2002. «Salsa Romantica: An Analysis of Style». En Situating Salsa: Global Markets and Local Meanings in Latin Popular Music, editado por Lise Waxer, 101-34. Nueva York y Londres: Routledge. 
Waxer, Lise. 1998. Cali Pachanguero: A Social History of Salsa in a Colombian City. University of Illinois at Urbana-Champaign.

— . 2000. «Hay una discusión en el barrio: el fenómeno de las viejotecas en Cali, Colombia». Actas del III Congreso Latinoamericano de la Asociación Internacional para el Estudio de la Música Popular. Bogotá.

- 2002. Situating Salsa: Global Markets and Local Meanings in Latin Popular Music. Nueva York y Londres: Routledge.

Yllahuamán Chipana, Wilder. 2004. «Frankie Dante. El sedicioso de la Salsa». Mamboinn.com: http://www.mambo-inn.com/index.php?option=com_content\&view = article\&id=502. 